\title{
TARGETING NOVEL SYNTHETIC ANTIOXIDANTS TOWARDS REDUCING FREE RADICAL - INDUCED CELL DAMAGE
}

\author{
by \\ MIHAELA FLUERARU, M.Sc.
}

A thesis submitted to the Faculty of Graduate Studies and Research in partial fulfillment of the requirements for the degree of

Doctor of Philosophy

Department of Chemistry

\author{
Carleton University \\ Ottawa, Ontario, Canada \\ June 2006 \\ (C) copyright \\ 2006, Mihaela Flueraru
}




$\begin{array}{ll}\begin{array}{l}\text { Library and } \\ \text { Archives Canada }\end{array} & \begin{array}{l}\text { Bibliothèque et } \\ \text { Archives Canada }\end{array} \\ \begin{array}{l}\text { Published Heritage } \\ \text { Branch }\end{array} & \begin{array}{l}\text { Direction du } \\ \text { Patrimoine de l'édition }\end{array} \\ \begin{array}{l}\text { 395 Wellington Street } \\ \text { Ottawa ON K1A 0N4 } \\ \text { Canada }\end{array} & \begin{array}{l}\text { 395, rue Wellington } \\ \text { Ottawa ON K1A ON4 } \\ \text { Canada }\end{array}\end{array}$

Your file Votre référence ISBN: 978-0-494-18217-8 Our file Notre référence ISBN: 978-0-494-18217-8

NOTICE:

The author has granted a nonexclusive license allowing Library and Archives Canada to reproduce, publish, archive, preserve, conserve, communicate to the public by telecommunication or on the Internet, loan, distribute and sell theses worldwide, for commercial or noncommercial purposes, in microform, paper, electronic and/or any other formats.

The author retains copyright ownership and moral rights in this thesis. Neither the thesis nor substantial extracts from it may be printed or otherwise reproduced without the author's permission.
AVIS:

L'auteur a accordé une licence non exclusive permettant à la Bibliothèque et Archives Canada de reproduire, publier, archiver, sauvegarder, conserver, transmettre au public par télécommunication ou par l'Internet, prêter, distribuer et vendre des thèses partout dans le monde, à des fins commerciales ou autres, sur support microforme, papier, électronique et/ou autres formats.

L'auteur conserve la propriété du droit d'auteur et des droits moraux qui protège cette thèse. $\mathrm{Ni}$ la thèse ni des extraits substantiels de celle-ci ne doivent être imprimés ou autrement reproduits sans son autorisation.
In compliance with the Canadian

Privacy Act some supporting forms may have been removed from this thesis.

While these forms may be included in the document page count, their removal does not represent any loss of content from the thesis.
Conformément à la loi canadienne sur la protection de la vie privée, quelques formulaires secondaires ont été enlevés de cette thèse.

Bien que ces formulaires aient inclus dans la pagination, il n'y aura aucun contenu manquant.

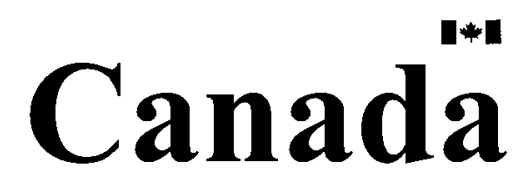




\begin{abstract}
The main objective of the thesis was to develop novel synthetic compounds with antioxidant activity superior to Vitamin E aimed at reducing free radical-induced cell damage. The bond dissociation enthalpy (BDE) for the most active (weakest) $\mathrm{OH}$ bond in each molecule was used as predictor of antioxidant activity. After synthesis and testing in chemical solvent, the novel synthetic compounds were tested for cytotoxicity and then for protective effects against oxidative stress in biological systems such as:

a. HL-60 cells used as a model for testing the antioxidant capacity of the novel compounds

b. an adherent clone of rat pheochromocytoma cells (PC12-AC). Oxidative stress was induced by the aqueous-phase peroxyl radical generator AAPH. Four members of the naphthalenediol family were tested, along with the reference compound epigallocatechin gallate (EGCG). The observed cytotoxicity and cytoprotection was explained based on the different electronic structures of the compounds, characterized by the first and second bond dissociation enthalpies and the $\mathrm{pKa}$ 's for the parent (diol) and semiquinone. The data were combined to create a measure of cytoprotective efficacy for each compound, defined by the CPA (cytoprotective area). The mechanism of cytotoxicity of catechols in PC12-AC cells was also studied. The three catechols tested strongly upregulated glutathione (GSH) synthesis in the first $24 \mathrm{~h}$ due to the production of hydrogen peroxide. c. primary cortical neurons. The study was extended in order to examine the effect of naphthalenediols on primary cortical neurons exposed to glutamate or peroxyl-radical oxidative stress. In cytotoxicity studies, cells were exposed to compounds for $24 \mathrm{~h}$, leading to observed toxicity in the order 1,4-ND $>1,2 \mathrm{ND}>>2,3-\mathrm{ND} \approx \mathrm{EGCG}>1,8-$
\end{abstract}


ND. This order was explained on the basis of the tendency of each compound to form their corresponding quinone, a factor which depends upon the loss of aromaticity in the quinone product. Excellent protection, superior to EGCG, was provided by 2,3- and 1,8NDs. Additional studies using glutamate as a stressor showed that 1,8-ND prevented neurotoxicity in a concentration-dependent manner, with a significant protective effect observed at concentrations as low as $500 \mathrm{nM}$. 


\section{Dedication}

To my husband, Costel and my sons, Andrei and Dragos, for their love and constant encouragement, support and advice 


\section{Acknowledgements}

I am deeply thankful to my supervisor, Dr. James Wright, who brought me into the wonderful and challenging antioxidant research area, for his kindness, generosity, patience, encouragement, guidance and support. He has been a great source of inspiration and motivation.

I owe a tremendous amount of gratitude to my co-supervisor, Dr. Bill Willmore for all his help, advice, valuable instructions, fruitful discussions, suggestions and always being available to answer my questions.

I would like to express my special thanks to Dr. Tony Durst, University of Ottawa for the synthesis of newly designed antioxidants. The work presented in this thesis would not be possible without his support, suggestions and guidance. The synthesis was carried skilfully by his group including Dr. Helmi Hussain, Gordana Babic, and Martin Charron. I am thankful for their help and suggestions.

I would like to thank Dr. Michael Poulter for provided valuable assistance, for advice and full support during the research in primary cortical neurons.

I would like to thank Dr. Keith Ingold, National Research Council for the kind and generous help with the Stopped-flow spectrometric measurements which enriched my research experience and for all the valuable suggestions and advice during the thesis research.

I would also like to thank Dr. David Miller, Carleton University. I was lucky to have benefited from his expertise during my years as a graduate student. He brought a unique insight to the Toxicology research field. Thank you for your support, suggestions and advice. 
I would like to thank my lab colleagues, Dr. Hooman Shadnia, Alexandru Chichirau, Leonid Chepelev, Remmick So, Eman Ahmed-Muhsin and Ray for their kindness, friendship, and assistance.

I would also like to thank a number of people who have contributed in various ways to this project. I want to express my thanks to Dr. Steffany Bennett, University of Ottawa Mr. Tim Ing, Carleton University and QBM Cell Science Inc., Ottawa for the supply of PC12-AC cells and primary cortical neurons, respectively.

It is a pleasure to thank Dr. Nathalie Chaly, Carleton University and Dr. Ross Barclay, Mount Allison University for help, valuable advice and assistance.

My sincere thank you goes to all the members of Dr Willmore's group: Ahmed, Angie, Nicholas and Mohamed.

Finally, I would like to say thank you to my husband, Costel who was always there for me, always believed in me, for his patience, love and continual support. I am grateful for his confidence in me. I love him and respect him so much more for that. I am also very thankful to my sons, Andrei and Dragos, for always believing in me and for being so openly proud of my accomplishments.

I am grateful to my parents for their love, encouragement and support. Their words of wisdom while they were miles away from me, in times of stress and frustration, still provided me with the enthusiasm to press forward.

Thank you all! 


\section{Table of content}

Title page $\quad$ i

Acceptance form $\quad$ ii

Abstract

Acknowledgments $\quad$ vi

Table of content viii

List of abbreviations $\quad \mathrm{X}$

List of tables $\quad$ xii

List of figures $\quad$ xiv

Chapter 1 General introduction 1

1.1 Reactive oxygen species 2

1.1.1. Lipid peroxidation 3

1.2 Antioxidant defence systems 4

1.2.1. Antioxidant enzymes 5

$\begin{array}{ll}\text { 1.2.2. Chemical antioxidants } & 7\end{array}$

$\begin{array}{ll}\text { 1.2.3. Pro-oxidant character of antioxidants } & 11\end{array}$

1.3 Oxidative stress and diseases associated with increased oxidative stress $\quad 12$

$1.4 \quad$ The design of synthetic antioxidants 13

$\begin{array}{ll}\text { 1.5. Hypothesis } & 17\end{array}$

1.6. Summary of aims and objectives $\quad 18$

1.7. References 19

Chapter 2 Novel synthetic antioxidants as free radicals scavengers: Design 30 strategy and testing with DPPH and HL-60 cell cultures

2.1 Introduction 31

2.2 Materials and methods 38

$\begin{array}{lll}2.3 & \text { Results } & 42\end{array}$

2.4 Discussion 60

2.5 Conclusion $\quad 69$

2.6 References $\quad 69$ 
Chapter 3 Cytotoxicity and protection of synthetic catechols: On the

relationship between structure, toxicity, protection and the effect of added ascorbate

$\begin{array}{lll}3.1 & \text { Introduction } & 77\end{array}$

3.2 Materials and methods $\quad 83$

3.3 Results 91

$\begin{array}{lll}3.4 & \text { Discussion } & 115\end{array}$

3.5 Conclusion 130

3.6 References 130

Chapter 4 Cytotoxicity and cytoprotective activity of naphthalenediols $\quad 140$ depends on their tendency to form naphthoquinone

$\begin{array}{lll}4.1 & \text { Introduction } & 141\end{array}$

4.2 Materials and methods 144

$\begin{array}{lll}4.3 & \text { Results } & 148\end{array}$

$\begin{array}{lll}4.4 & \text { Discussion } & 167\end{array}$

$\begin{array}{lll}4.5 & \text { Conclusion } & 181\end{array}$

$\begin{array}{lll}4.6 & \text { References } & 181\end{array}$

Chapter 5 Cytotoxicity and cytoprotective activity of naphthalenediols in rat 187 cortical neurons

$\begin{array}{lll}5.1 & \text { Introduction } & 188\end{array}$

5.2 Materials and methods 190

$\begin{array}{lll}5.3 & \text { Results } & 194\end{array}$

$\begin{array}{lll}5.4 & \text { Discussion } & 207\end{array}$

$\begin{array}{lll}5.5 & \text { Conclusion } & 211\end{array}$

$\begin{array}{lll}5.6 & \text { References } & 212\end{array}$

$\begin{array}{lll}\text { Chapter } 6 & \text { General conclusions } & 218\end{array}$

$\begin{array}{ll}\text { Publication list } & 224\end{array}$ 


\section{List of Abbreviations}

AAPH - 2,2'-azobis (2-amidinopropane) hydrochloride

ADMET - absorption-distribution-metabolism-excretion-toxicity

AD - Alzheimer's disease

ALS - amyotrophic lateral sclerosis

AM1 - Austin Model 1

$\mathrm{RO}^{\bullet}$ - alkoxyl radical

BDE - Bond Dissociation Enthalpy

CPA - Cytoprotective Area

HL-60 - cultured human leukemia cells

DFT - density functional theory

DNA - deoxyribonucleic acid

DPPH - 2,2-diphenyl-1-picrylhydrazyl free radicals

DMSO - dimethyl sulfoxide

DCF - Dichlorofluorescein

$\mathrm{H}_{2}$ DCF-DA - 2'7'-dichlorodihydrofluorescein diacetate

DTNB - 5,5'dithiobis-2-nitrobenzoic acid

EDTA - ethylenediaminetetraacetic acid

EGCG - (-) epigallocatechin gallate

HBSS - Hanks' balanced salt solution

HAT - Hydrogen Atom Transfer

$\mathrm{H}_{2} \mathrm{O}_{2}$ - hydrogen peroxide

$\mathrm{HOCl}$ - hypochlorous acid

$\mathrm{HOO}^{\circ}$ - hydroperoxyl radical

$\mathrm{OH}^{\bullet}$ - hydroxyl radical

IP - Ionization Potential

IkB - inhibitor of kappa B

LDBS - locally dense basis sets

LLM - lowest level method

MTT - (3-(3,5-dimethylthiazol-2-yl)-2,5diphenyltetrazoliumbromide)

NMDA - N-methyl-D-aspartic acid 
$\mathrm{NADH}$ - nicotinamide adenine dinucleotide, reduced form

$\mathrm{NADPH}$ - nicotinamide adenine dinucleotide phosphate, reduced form

NF-kB - nuclear factor-kappa B

$\log \mathbf{P}$ - octanol-water partition coefficient

GSSG - oxidized glutathione

PD - Parkinson's disease

$\mathrm{ROO}^{\circ}$ - peroxyl radical

PMA - phorbol 12-myristate 13-acetate

PBS - phosphate buffered saline

ROS - reactive oxygen species

GSH - reduced glutathione

PC12 - rat adrenal pheochromocytoma cells

RPMI 1640 - Roswell Park Memorial Institute medium

SPLET - Sequential Proton Loss Electron Transfer

SET - Single Electron Transfer

$\mathrm{O}_{2}{ }^{--}$- superoxide radical

SOD - superoxide dismutase

SAR - structure-activity relationship

$\alpha$-TOH $-\alpha$-tocopherol 


\section{List of tables}

2.1. Additive effects on the BDE value in phenolic compounds relative to phenol 35 $(87 \mathrm{kcal} / \mathrm{mol})$.

2.2. Bond dissociation enthalpy $\left(\Delta \mathrm{H}^{\mathrm{o}}{ }_{298}\right)$ for catechols and reference compounds:

$\mathrm{BDE}_{1}$ is for catechol $\rightarrow$ semiquinone, $\mathrm{BDE}_{2}$ is for semiquinone $\rightarrow$ quinone.

2.3. Data obtained from stopped-flow analysis of different concentrations of $\mathrm{H} 3$ reacting with $\mathrm{DPPH}^{\bullet}$ in ethyl acetate: time of reaction, rate constants of each run $(n=4)$ and the average of $k_{\text {exp }}$.

2.4. Rate constants for $\mathrm{DPPH}^{\bullet}+$ compounds in ethyl acetate solvent, $\mathrm{R}^{2}$ values, calculated $\mathrm{BDE}_{\mathbf{l}}$.

2.5. Rates of $\mathrm{O}_{2}{ }^{\bullet-}$ production by five different concentrations of cells and calculated nmols of $\mathrm{O}_{2}{ }^{--}$produced per min by $10^{6}$ cells.

2.6. Free energy changes $\Delta \mathrm{G}^{0}{ }_{298}$ for various reactions which involve a phenol $(\mathrm{ArOH})$ or a catechol $\left(\mathrm{QH}_{2}\right)$ in gas phase and in solution. The equilibrium constants $\mathrm{K}_{\mathrm{eq}}$ at $298 \mathrm{~K}$ are presented.

3.1. Bond dissociation enthalpy $\left(\Delta \mathrm{H}^{\circ}{ }_{298}\right)$ and $\log \mathrm{P}$ values for catechols and

EGCG: $\mathrm{BDE}_{1}$ is for catechol $\rightarrow$ semiquinone, $\mathrm{BDE}_{2}$ is for semiquinone $\rightarrow$ quinone. $\mathrm{QH}_{2}=$ parent catechol, $\mathrm{Q}=$ quinone derived from the catechol.

4.1 Bond dissociation enthalpy $\left(\Delta \mathrm{H}^{\mathrm{o}}{ }_{298}\right)$, calculated $\log \mathrm{P}(\log \mathrm{P}), \mathrm{pKa}$, and $\mathrm{EC}_{50}$ of naphthalenediols with and without ascorbate, $\mathrm{BDE}_{1}$ is for naphthalenediol $\rightarrow$ naphthosemiquinone, $\mathrm{BDE}_{2}$ is for naphthosemiquinone $\rightarrow$ naphthoquinone.

4.2. Cytoprotective efficacy of antioxidants against oxidative stress induced by 12 mM AAPH. Incubation time: $24 \mathrm{~h}, 2 \mathrm{~h}$ pretreatment with antioxidant.

4.3. $\mathrm{EC}_{50}$ and cytoprotective efficacy of substituted 1,8-NDs against oxidative stress induced by $12 \mathrm{mM}$ AAPH. Incubation time: $24 \mathrm{~h}, 2 \mathrm{~h}$ pretreatment with antioxidant.

5.1. Calculated $\mathrm{BDE}_{1}$ and $\mathrm{BDE}_{2}$, the cytotoxicity $\mathrm{EC}_{50}$ for PC12-AC cells [11] and for cortical neurons and the ratio of the $\mathrm{EC}_{50}$ 's between the cell lines. 
5.2. Cytoprotective efficacy of antioxidants against oxidative stress induced by

$1.5 \mathrm{mM}$ AAPH. Incubation time is $24 \mathrm{~h}, 2 \mathrm{~h}$ pretreatment with antioxidant. 


\section{List of Figures}

1.1. The chemical structure of $\alpha$-tocopherol. $\quad 7$

1.2. Structure of $\alpha$-tocopherol, an analogue of $\alpha$-tocopherol and probucol. 15

2.1. Structural formulas for the compounds tested: 2-Hydroxymethyl-4- 43 methoxy-phenol $=\mathrm{H}_{0}$, new synthetic catechols $\mathrm{H}, \mathrm{H} 1, \mathrm{H} 2, \mathrm{H} 3, \mathrm{H} 4$ and known reference antioxidants EGCG, propyl gallate, resveratrol, vitamin $\mathrm{E}$, and Trolox (water-soluble vitamin E).

2.2. Plot of the first order rate constant $k_{\exp }$ vs. concentration of $\mathrm{H} 3$. 47

2.3. Plot of $\log \mathrm{k}_{\mathrm{DPPH}}$ vs. calculated BDEs of $\mathrm{H}_{0}, \mathrm{H}, \mathrm{H} 1, \mathrm{H} 2, \mathrm{H} 3, \mathrm{H} 4$, and 49 Vitamin E.

2.4. Log (concentration of HL-60 cells) vs time (h). 50

2.5. Plot of Log (concentration of HL-60 cells) vs time (h). 52

2.6. Change in cytochrome $\mathrm{C}$ absorbance over time for different cell 53 concentrations.

2.7. Absorbance vs. concentration of EGCG. 55

2.8. Absorbance vs. concentration of resveratrol. 56

2.9. Absorbance vs. concentration of propyl gallate. 56

2.10. Absorbance vs. concentration of Trolox (water-soluble Vit. E). 57

2.11. Absorbance vs. concentration of $\mathrm{H} 1$. 57

2.12. Absorbance vs. concentration of $\mathrm{H} 2$. 58

2.13. Absorbance vs. concentration of H3. 58

2.14 Absorbance vs. concentration of $\mathrm{H} 4$. 59

2.15. Plot of $\mathrm{IC}_{50}$ vs. BDE for synthetic compounds H1, H2, H3, H4 and known 60 antioxidant EGCG, propyl gallate, resveratrol, and Trolox.

2.16. Structure of fully substituted catechol H1. 63

3.1. Structural formulas for the synthetic catechols $\mathrm{H} 1, \mathrm{H} 2$, and $\mathrm{H} 4$ and their 92 diacetates H1-DA, H2-DA, H4-DA and EGCG = (-)-epigallocatechin gallate.

3.2. Cytotoxicity of three catechols H1, H2, H3 and their diacetates H1-DA, 94 
H2-DA, and H4-DA and the known compound EGCG as measured by MTT assay.

3.3a. Cytotoxicity response curve for $\mathrm{H} 1, \mathrm{H} 1+50 \mu \mathrm{M}$ ascorbate, showing \% 96 live cells relative to control (MTT assay) vs. conc. of $\mathrm{H} 1$.

3.3b. Cytotoxicity response curve for the acetylated compound H1-DA, H1-DA 96 $+50 \mu \mathrm{M}$ ascorbate.

3.4a. Cytotoxicity response curve for $\mathrm{H} 2, \mathrm{H} 2+50 \mu \mathrm{M}$ ascorbate and $\mathrm{H} 2+75 \quad 97$ $\mu \mathrm{M}$ ascorbate.

3.4b. Cytotoxicity response curve for the acetylated compound H2-DA, H2-DA $+50 \mu \mathrm{M}$ ascorbate.

3.5a. Cytotoxicity response curve for $\mathrm{H} 4, \mathrm{H} 4+50 \mu \mathrm{M}$ ascorbate. 98

3.5b. Cytotoxicity response curve for H4-DA, H4-DA + $50 \mu \mathrm{M}$ ascorbate. 98

3.6. Cell viability (MTT assay) for PC12-AC cells vs concentration of 99 ascorbate

3.7. H2-DA $(20 \mu \mathrm{M})$ generates superoxide ion in differentiated HL-60 cells, 100 causing an absorbance change due to reduction of cytochrome C(III).

3.8. Fluorescence vs. concentration of H2-DA.

3.9a. (Extracellular) $\mathrm{H}_{2} \mathrm{O}_{2}$ concentration vs. concentration of $\mathrm{H} 1, \mathrm{H} 1+$ Ascorbate $(50 \mu \mathrm{M})$ and $\mathrm{H} 1-\mathrm{DA}$.

3.9b. (Extracellular) $\mathrm{H}_{2} \mathrm{O}_{2}$ concentration vs. concentration of $\mathrm{H} 2-\mathrm{DA}, \mathrm{H} 2-\mathrm{DA}+$ Ascorbate $(50 \mu \mathrm{M})$.

3.9c. (Extracellular) $\mathrm{H}_{2} \mathrm{O}_{2}$ concentration vs. concentration of $\mathrm{H} 4, \mathrm{H} 4+$ Ascorbate $(50 \mu \mathrm{M})$ and H4-DA.

3.10. $\mathrm{H}_{2} \mathrm{O}_{2}$ response curves as a function of time (FOX1 assay) for each test compound in its diacetate form.

3.11. GSH response curves as a function of concentration of diacetates H1-DA, H2-DA, and H4-DA.

3.12. Cell viability (MTT assay) for PC12-AC cells vs. concentration of menadione.

3.13a. Effects of H2-DA $(10 \mu \mathrm{M})$ and H2-DA + ascorbate on the viability of 
menadione $(50 \mu \mathrm{M})$-treated PC12-AC cells.

3.13b. Effects of H2-DA $(20 \mu \mathrm{M})$ and H2-DA + ascorbate on the viability of 110 menadione $(50 \mu \mathrm{M})$-treated PC12-AC cells.

3.14 Effects of H2-DA and EGCG on the viability of menadione $(50 \mu \mathrm{M})$ treated PC12-AC cells.

3.15. Cell viability (MTT assay) for PC12-AC cells vs. concentration of AAPH

3.16. Cytoprotection of H2-DA and EGCG against AAPH-induced oxidative stress

3.17 Total cytoprotective area (CPA) for H2-DA (the cross-hatched region) showing a narrow range of protection between 0 and $40 \mu \mathrm{M}$.

3.18 Total cytoprotective area for EGCG (cross-hatched region).

3.19 Structure of compounds 5 and 9 [57]

4.1. Structural formulas for the 9 compounds tested, where $1,2-\mathrm{ND}-\mathrm{DA}=1,2$ naphthalenediol-diacetate, 1,8-ND-DGly = 1,8-ND-diglycerate and EGCG $=(-)$-epigallocatechin gallate.

4.2. Cytotoxicity of the naphthalenediols, initially present as the diacetates, and the reference compound EGCG.

4.3. $\mathrm{H}_{2} \mathrm{O}_{2}$ response curves as a function of time (FOX1 assay) for each test compound in its diacetate form.

4.4. Cell viability (MTT assay) for PC12-AC cells vs. concentration of AAPH.

4.5. Cytoprotection against AAPH-induced oxidative stress for compounds 1,2ND-DA and 1,4-ND-DA.

4.6. Cytoprotection of PC12-AC cells by naphthalenediols with AAPH (12 $\mathrm{mM}$ ) as a stressor including 2,3-ND, 1,8-ND, DPND (as diacetates), and EGCG.

4.7. Total Cytoprotective area for EGCG (both cross-hatched regions).

4.8. Total Cytoprotective area for 2,3-ND (both cross-hatched regions), showing a more extended cytoprotection experiment, with data out to 350 $\mu \mathrm{M}$.

4.9. Cell viability (MTT assay) for PC12-AC cells vs concentration of 
ascorbate.

4.10. Cytotoxicity response curve for $1,8 \mathrm{ND}-\mathrm{DA}$ and $1,8 \mathrm{ND}-\mathrm{DA}$ with $75 \mu \mathrm{M} 159$ ascorbate

4.11. Cytotoxicity response curve for DPND-DA and DPND-DA with $50 \mu \mathrm{M} 160$ ascorbate.

4.12. Cytotoxicity response curve for 2,3ND-DA and 2,3ND-DA with $75 \mu \mathrm{M} 160$ ascorbate.

4.13. Cytotoxicity response curve for $1,2 \mathrm{ND}-\mathrm{DA}$ and $1,2 \mathrm{ND}-\mathrm{DA}$ with $50 \mu \mathrm{M} 161$ ascorbate.

4.14. Cytotoxicity response curve for 1,4ND-DA and 1,4ND-DA with $50 \mu \mathrm{M} 161$ ascorbate.

4.15. Cytotoxicity of the 1,8-ND-DA and substituted 1,8-NDs (1,8-ND-DA 162 acrylamide; 1,8-ND-DA acrylate, 1,8-ND-DGly)

4.16 Total Cytoprotective area for 1,8-ND-DGly (both cross-hatched regions), 163 showing an extended cytoprotection experiment, with data up to $300 \mu \mathrm{M}$.

4.17. Total Cytoprotective area for 1,8-ND-DA-acrylamide (both cross-hatched regions), showing an extended cytoprotection experiment, with data up to 164 $300 \mu \mathrm{M}$.

4.18. Total Cytoprotective area for substituted 1,8-ND-DA acrylate (both cross- 165 hatched regions).

4.19. Energetics and structural changes for the naphthalenediol $\rightarrow 173$ naphthosemiquinone $\rightarrow$ naphthoquinone.

5.1. Structural formulas for the 5 compounds tested, where 1,2-ND-DA $=1,2-194$ naphthalenediol diacetate, etc. and EGCG $=(-)$-epigallocatechin gallate.

5.2. Cell viability of rat cortical neurons (MTT assay) after $24 \mathrm{~h}$ incubation 195 with naphthalenediols and EGCG.

5.3. Cell viability (MTT assay) for primary cortical neurons vs. concentration 196 of AAPH.

5.4. Cytoprotection of cortical neurons by selected naphthalenediols, in 197 presence of AAPH (1.5 mM). Compounds tested: 2,3-ND, 1,8-ND (as 
diacetates) and EGCG.

5.5. Total Cytoprotective Area for 1,8-ND (shaded regions). 200

5.6. Total Cytoprotective Area for 2,3-ND (shaded regions). 200

5.7. Total Cytoprotective Area for EGCG (shaded regions). 200

5.8. Cytotoxicity of glutamate to cortical neurons (trypan blue assay). 201

5.9. Image of primary cortical neurons with no treatment (Control). 202

5.10. Image of primary cortical neurons stressed with $250 \mu \mathrm{M}$ glutamate. 203

5.11. Image of primary cortical neurons stressed with $250 \mu \mathrm{M}$ glutamate and 203 protected by $10 \mu \mathrm{M} 1,8-\mathrm{ND}-\mathrm{DA}$ treatment.

5.12. Cytoprotection of cortical neurons by 1,8 -ND showing low-dose protection 204 


\section{Chapter 1}

\section{General Introduction}




\subsection{REACTIVE OXYGEN SPECIES}

Reactive oxygen species (ROS) are continuously produced in organisms as part of normal aerobic metabolism $[1,2]$ as well as after exposure to environmental stressors such as radiation [3] or cigarette smoke [4]. ROS include the superoxide radical $\left(\mathrm{O}_{2}{ }^{--}\right)$, hydrogen peroxide $\left(\mathrm{H}_{2} \mathrm{O}_{2}\right)$, hypochlorous acid $(\mathrm{HOCl})$, hydroxyl radical $\left(\mathrm{OH}^{\bullet}\right)$, peroxyl radical $\left(\mathrm{ROO}^{\circ}\right)$, hydroperoxyl radical $\left(\mathrm{HO}_{2}{ }^{\circ}\right)$ and alkoxyl radical $\left(\mathrm{RO}^{\circ}\right)$ [5]. With the exception of $\mathrm{H}_{2} \mathrm{O}_{2}$ and $\mathrm{HOCl}$, all species contain an unpaired electron in the outer orbital of oxygen. Such free radicals are highly reactive and chemically destructive, reacting with non-radical molecules from which they extract electrons [6]. The non-radical molecule, in turn, becomes a radical itself, leading to a molecular chain reaction which generates more free radicals and leads to an amplification of damage.

ROS are continuously generated through normal aerobic metabolism. Approximately $90 \%$ of the oxygen used by the cell is consumed by the mitochondria, a small proportion of which leads to the generation of ROS [7]. Therefore, the rate of mitochondrial ROS formation increases by increasing the metabolic rate [7].

During metabolism, oxygen undergoes a four-electron reduction to produce water in mitochondria, reactions which are catalyzed by cytochrome c oxidase [8,9]. However, a small percentage of the oxygen undergoes one-electron reduction leading to several ROS and hydrogen peroxide according to the following reactions [10]:

$$
\begin{array}{ll}
\mathrm{O}_{2}+e^{-} \rightarrow \mathrm{O}_{2}^{\bullet-} & \text { Superoxide radical } \\
\mathrm{O}_{2}^{\bullet-}+\mathrm{H}^{+} \rightleftarrows \mathrm{HO}_{2}^{\bullet} & \text { Hydroperoxyl radical } \\
\mathrm{HO}_{2}^{\bullet}+e^{-}+\mathrm{H}^{+} \rightarrow \mathrm{H}_{2} \mathrm{O}_{2} & \text { Hydrogen peroxide } \\
\mathrm{H}_{2} \mathrm{O}_{2}+e^{-} \rightarrow \mathrm{OH}^{\bullet}+\mathrm{OH}^{-} & \text {Hydroxyl radical }
\end{array}
$$


Hydrogen peroxide is not a radical but is one of the most studied ROS. It has a relatively long half-life and can readily move through membranes [11]. The dismutation of superoxide radicals, according to the equation:

$$
\mathrm{O}_{2}{ }^{--}+\mathrm{O}_{2}^{\cdot-}+2 \mathrm{H}^{+} \rightarrow \mathrm{H}_{2} \mathrm{O}_{2}+\mathrm{O}_{2}
$$

is the main source of intracellular hydrogen peroxide. Hydrogen peroxide contributes significantly to oxidative stress. It can undergo Fenton-type reactions with metals such as $\mathrm{Fe}^{2+}$ and $\mathrm{Cu}^{+}$to produce $\mathrm{OH}^{\bullet}$ radicals [12], according to

$$
\mathrm{Fe}^{2+}\left(\mathrm{Cu}^{+}\right)+\mathrm{H}_{2} \mathrm{O}_{2} \rightarrow \mathrm{Fe}^{3+}\left(\mathrm{Cu}^{2+}\right)+\mathrm{OH}^{\bullet}+\mathrm{OH}^{-}
$$

Hydroxyl radicals are extremely reactive and can damage all major macromolecules of the cell $[13,14]$. They can also be generated through the Haber-Weiss reaction [15].

$$
\mathrm{O}_{2}^{--}+\mathrm{H}_{2} \mathrm{O}_{2} \rightarrow \mathrm{O}_{2}+\mathrm{OH}^{-}+\mathrm{OH}^{\bullet}
$$

Other sources of ROS include the peroxisomal $\beta$-oxidation of fatty acids, cytochrome P450 reactions, phagocytic cells (respiratory burst), metabolism of xenobiotic compounds, and tissue specific enzymes (e.g. xanthine oxidase).

\subsubsection{Lipid peroxidation}

An important target of ROS is the biomembrane which contains fatty acids (lipids). The mechanism of lipid peroxidation is a chain reaction which proceeds in three stages $[5,16,17]$ :

Initiation: $\quad$ production of $\mathrm{R}^{\bullet}: \mathrm{RH} \rightarrow \mathrm{R}^{\bullet}$

Propagation: $\mathrm{R}^{\bullet}+\mathrm{O}_{2} \rightarrow \mathrm{ROO}^{\bullet}$

$$
\mathrm{ROO}^{\bullet}+\mathrm{RH} \rightarrow \mathrm{ROOH}+\mathrm{R}^{\bullet}
$$

Termination: $\mathrm{ROO}^{\bullet}+\mathrm{ROO}^{\bullet} \rightarrow \mathrm{ROOR}+\mathrm{O}_{2}$ 


$$
\begin{aligned}
& 2 \mathrm{R}^{\bullet} \rightarrow \mathrm{R}-\mathrm{R} \\
& \mathrm{R}^{\bullet}+\mathrm{ROO}^{\bullet} \rightarrow \mathrm{ROOR}
\end{aligned}
$$

The initiation reaction can be nonenzymatic (caused by heat, light, or by a single electron transfer (SET) from a reducing agent such as $\mathrm{Fe}^{2+}$ to an acceptor such as $\mathrm{ROOH}$ ) or an enzyme-catalyzed SET reaction. Once a free radical $\mathrm{R}^{\bullet}$ has been generated, then reactions (9) and (10) form a chain reaction. Reaction (9) is very fast, with a rate constant of ca. $10^{9} \mathrm{M}^{-1} \mathrm{~s}^{-1}$ whereas (10) is much slower, typically $10^{1} \mathrm{M}^{-1} \mathrm{~s}^{-1}$ [16]. Termination of the chain reaction takes place with quenching of the propagating free radical through various pathways (11)-(13) [16]. Lipid peroxidation can be lethal to the cell by decreasing the cell membrane fluidity and increasing the "leakiness" of the membrane bilayer to substances such as $\mathrm{Ca}^{2+}$ ions that normally cross it through specific channels [5]. The influx of $\mathrm{Ca}^{2+}$ activates $\mathrm{Ca}^{2+}$-activated phospholipases which further destroy the cell membrane resulting in cell lysis.

\subsection{ANTIOXIDANT DEFENCE SYSTEMS}

As a result of a continuous production of ROS and the possibility of lipid peroxidation, cells have evolved potent and complex antioxidant defence systems to protect themselves. The term antioxidant, as defined by Halliwell and Gutteridge [18], is any substance that, when present at low concentrations compared to that of an oxidizable substrate, significantly delays or inhibits oxidation of that substrate".

There are three kinds of antioxidant systems:

i) antioxidant enzymes: the primary system or preventive antioxidants which limit the initial formation of oxygen centred radicals (peroxyl and alkoxyl radicals). 
ii) chemical antioxidants: the secondary scavenging system or chain-breaking antioxidants which interrupt chain reactions propagated by ROS already present (vitamin E, vitamin C, carotenoids, coenzyme Q, glutathione).

iii) repair mechanisms: the third system which includes enzymes for repairing damaged proteins (methionone sulphoxide reductase for repairing oxidised methionine residues), lipids (phospholipase $\mathrm{A}_{2}$, lecithin cholesterol acyltransferase [5]) and DNA (many enzymes such as endonuclease III, DNA glycosylase) [19].

\subsubsection{Antioxidant enzymes}

The primary antioxidant system includes enzymes which play important roles in the control of formation and proliferation of ROS resulting from molecular oxygen. Enzymatic defence systems include superoxide dismutase (SOD), catalase, glutathione peroxidase, and glutathione reductase.

Superoxide dismutase is the principal enzyme of the biological defence against the damage caused by $\mathrm{O}_{2}^{\bullet-}[20,21]$. SOD catalyzes the dismutation of superoxide anions to hydrogen peroxide and oxygen, according to reaction (5). The rate of reaction (5) is approximately $10^{4}$ times greater than that of the spontaneous dismutation at physiological pH [1,20,22]. In mammalian tissues, two different superoxide dismutases occur depending on their cellular location and metal ion content: $\mathrm{Cu} / \mathrm{ZnSOD}$ present in cytoplasm of most cells and MnSOD within the mitochondria [20]. The liver, adrenal gland, kidney, and spleen contain large amounts of SOD.

Catalase is an enzyme (tetrameric hemoprotein) located in peroxisomes of most tissues [5,10]. This enzyme catalyses reduction of $\mathrm{H}_{2} \mathrm{O}_{2}$ to water, according to the general reaction 


$$
2 \mathrm{H}_{2} \mathrm{O}_{2} \rightarrow 2 \mathrm{H}_{2} \mathrm{O}+\mathrm{O}_{2}
$$

The activity of catalase varies among the tissues. There is a high level of catalase in liver, kidney and red blood cells and less in brain, heart and skeletal muscle [23]. Catalase shares the function of removing $\mathrm{H}_{2} \mathrm{O}_{2}$ with another enzyme, glutathione (GSH) peroxidase. At high concentrations, $\mathrm{H}_{2} \mathrm{O}_{2}$ is removed by catalase and at low concentrations, organic peroxides are removed by GSH peroxidase (utilizing glutathione in the process) [10].

Glutathione (GSH) peroxidase is a selenium dependent enzyme (most forms) which catalyzes the following reactions using glutathione as the reducing substrate:

$$
\begin{aligned}
& 2 \mathrm{GSH}+\mathrm{H}_{2} \mathrm{O}_{2} \rightarrow \mathrm{GSSG}+2 \mathrm{H}_{2} \mathrm{O} \\
& 2 \mathrm{GSH}+\mathrm{ROOH} \rightarrow \mathrm{GSSG}+\mathrm{H}_{2} \mathrm{O}+\mathrm{ROH}
\end{aligned}
$$

This decreases the oxidative damage produced by lipid peroxidation. There are also two other known GSH peroxidases: selenium independent GSH peroxidase [24] and phospholipid hydroperoxide glutathione peroxidase (an enzyme associated with membranes $[25,26])$. Both enzymes catalyze only the reduction of lipid hydroperoxides.

Glutathione reductase is a flavoprotein that reduces oxidised glutathione to replenish reduced GSH using NADPH, according to the equation:

$$
\mathrm{GSSG}+\mathrm{NADPH}+\mathrm{H}^{+} \rightarrow 2 \mathrm{GSH}+\mathrm{NADP}^{+}
$$

The enzyme is localized primarily in the cytosol, also in the membrane-bound organelles and mitochondrial matrix [5]. The ratio GSH/GSSG is used as an indicator of oxidative stress in tissues. 


\subsubsection{Chemical antioxidants}

Chain-breaking antioxidants include vitamin E, vitamin $\mathrm{C}$, glutathione, carotenoids, uric acid and bilirubin. In the next section some of the antioxidants which are relevant for our studies will be discussed.

Vitamin $\mathbf{E}$ is the most effective lipid-soluble chain-breaking antioxidant [27]. Vitamin E exists in eight naturally occurring different forms, four tocopherols and four tocotrienols (Figure 1.1) [27]. Each form has its own biological activity.<smiles>Cc1c(C)c2c(c(C)c1O)CC[C@](C)(CCCCCCCCCOC(=O)O[Na])O2</smiles>

Figure 1.1. The chemical structure of $\alpha$-tocopherol.

Alpha-tocopherol (or $\alpha$-TOH) is the most active form of vitamin $\mathrm{E}$ in humans. It is also a powerful biological antioxidant [28]. The main role of Vitamin $E$ is to protect against membrane lipid peroxidation by reacting with lipid peroxyl radicals and alkoxyl radicals. $\alpha-\mathrm{TOH}$ intercepts peroxyl radicals generated by lipid peroxidation with a rate constant of $10^{6} \mathrm{M}^{-1} \mathrm{~s}^{-1}$ [28], according to the equation:

$$
\alpha-\mathrm{TOH}+\mathrm{RO}_{2}^{\bullet} \rightarrow \alpha-\mathrm{TO}^{\bullet}+\mathrm{ROOH}
$$

In addition to its antioxidant behaviour, Vitamin $\mathrm{E}$ is a membrane-stabilizing agent through its van der Waals interaction with membrane phospholipids, thus preventing the damaging actions of phospholipases [29,30]. 
Vitamin $\mathbf{C}$ is an excellent water-soluble reducing agent. It plays an important role in cellular redox reactions $[31,32]$. At the $\mathrm{pH}$ of $7.4,99.95 \%$ of vitamin $\mathrm{C}$ will be present as ascorbate $\left(\mathrm{AscH}^{-}\right)$and only $0.05 \%$ as ascorbic acid $\left(\mathrm{AscH}_{2}\right)\left(\mathrm{pK}_{1}=4.17\right)[33]$. Ascorbate (the negatively charged lactone of ascorbic acid) is found in the cytoplasm of the cells. Ascorbate loses one electron leading to the semidehydroascorbate radical $\left(\mathrm{AscH}{ }^{\bullet}\right)$. This rapidly ionizes to the ascorbyl radical anion $\left(\mathrm{Asc}^{\circ-}\right)$ which can be further oxidized to give dehydroascorbic acid (DHA), according to Scheme 1.1 [5,33].

\section{SCHEME 1.1}

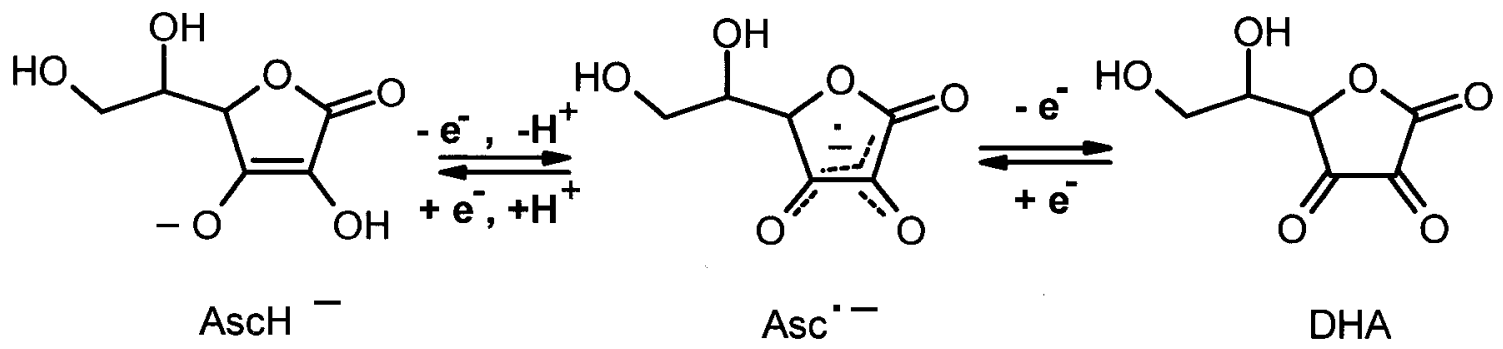

Dehydroascorbic acid is converted back to ascorbic acid by a glutathione-dependent enzyme, dehydroascorbate reductase [34,35], according to the reaction:

$$
\mathrm{DHA}+2 \mathrm{GSH} \rightarrow \mathrm{AscH}_{2}+\mathrm{GSSG}
$$

Ascorbate can react with and scavenge various reactive species such as $\mathrm{O}_{2}{ }^{\bullet-}$, $\mathrm{HO}_{2}{ }^{\bullet}, \mathrm{OH}^{\bullet}$, and $\mathrm{HOCl}$ (in chronic inflammation [5]). Wefers et al showed that ascorbate is an efficient scavenger in vitro of singlet oxygen [36].

Vitamin $\mathrm{C}$ and Vitamin $\mathrm{E}$ function synergistically to protect membrane lipids from damage by quenching the free radicals [37-39]. Vitamin $\mathrm{C}$ regenerates the reduced form of vitamin E. Ascorbate acts as an electron-transfer agent at the water/membrane interface, where the $\alpha$-tocopheroxyl radical reacts with ascorbate with the regeneration of $\alpha-\mathrm{TOH}[37,40]$, according to the equation: 


$$
\alpha-\mathrm{TO}^{\bullet}+\mathrm{AscH}^{-} \rightarrow \alpha-\mathrm{TOH}+\mathrm{Asc}^{\bullet-}
$$

Glutathione (GSH), a tripeptide composed of L-glutamate, L-cysteine and glycine, protects against free radical damage by providing reducing equivalents for key enzymes such as glutathione-S-transferase (with role in detoxification of xenobiotics) and GSH-peroxidase (antioxidant enzyme) [23]. It is an electron donor via the sulfhydryl group of the cysteine. Its concentration in the cell can be in the millimolar range while most other components generally tend to be in the micromolar range.

Another important role of GSH is that of a free radical scavenger. GSH reacts directly with peroxyl, phenoxyl and semiquinone radicals and is effective in scavenging hydroxyl radicals and singlet oxygen [23]. It is also involved in the regeneration of ascorbate from its oxidized form, dehydroascorbic acid.

Glutathione participates in DNA synthesis and repair, protein synthesis, amino acid transport, enhancement of immune function and enzyme activation [41]. It plays an essential role in the nervous system as a redox modulator of some ionotropic water receptor currents and as a potential neurotransmitter [42].

Natural polyphenols such as flavonoids and catechins are important constituents of fruits, vegetables, nuts, seeds, tea, olive oil and red wine. [43]. These polyphenols inhibit lipid peroxidation and lipoxygenases in vitro. Many studies have shown the beneficial effects of tea polyphenolic compounds on quenching free radicals and their role in the prevention and therapy of disease [45,47]. The anti-inflammatory, hepatoprotective, antithrombotic, and antiviral activities of polyphenols are related, in part, to their ability to scavenge a wide range of ROS such as $\mathrm{OH}^{\circ}, \mathrm{O}_{2}{ }^{\circ}, \mathrm{RO}^{\circ}$, and $\mathrm{RO}_{2}{ }^{\circ}$ $[44,45]$. They can also chelate metal ions decreasing their metal ion prooxidant effects 
[46]. Their antioxidant efficiency will dependent on their bioavailability to cells and tissues and the ability to interact with and penetrate lipid bilayers causing variations in the cell membrane structure and fluidity. The uptake of flavonoids into the cytosol is dependent on cell type [47]. Modification of cholesterol concentrations in cell membranes will influence the incorporation, uniformity of distribution, and the orientation of antioxidants in the lipid bilayers changing in this way their antioxidant efficiency [48]. Cholesterol depletion in erythrocytes causes a significant decrease in the protection offered by antioxidants against oxidative damage induced by ROS.

Many studies have suggested that natural polyphenols exert their biological actions not only through their hydrogen-donating antioxidant capacity but also by interaction with intracellular protein kinase and lipid kinase signalling cascades such as phosphoinositide 3-kinase, Akt/PKB, tyrosine kinases, protein kinase $\mathrm{C}$, and MAP kinases) $[49,50,51]$. Flavonoids have the ability to bind to the ATP sites on enzymes such as mitochondrial ATPase, protein kinase A, topoisomerase and protein kinase C [50,52,53]. Flavonoids interfere with pathways of intermediary metabolism, and downregulate the expression of adhesion molecules [54].

It was demonstrated that specific flavonoids can suppress the induction of inducible nitric oxide synthase (iNOS - an inflammatory mediator) gene and protein expression, and NO- production by cytokines and endotoxins in mouse macrophage RAW 264.7 cells $[49,55,56]$. The mechanism was not due to a direct inhibitory effect on enzyme activity, but rather the modulation of cell signalling pathways necessary for NOS gene expression. 
In lung cells, low amounts of phenolic antioxidants can regulate redox signalling [57]. They inhibit the inflammatory process by suppressing the activity of nuclear factorkappa B (NF-kB - an important modulator of inflammatory responses occurring in tubular epithelial cells) either through nuclear factor E2 p45-related factor 2 (Nrf2) induced phase-2 antioxidant enzymes (GSH), inhibitor of kappa B (IkB) pathway or reducing the activity of ROS and p38 mitogen activated protein (MAP) kinase. The antioxidants can also upregulate histone deacetylase (HDAC) activity and /or repair the modified HDAC proteins. Thus, antioxidants as study in this thesis involve scavenging of ROS but in fact they can play an additional role which involve cell signalling.

In all our studies, epigallocatechin gallate (EGCG) was used as a reference compound because of its strong demonstrated antioxidant ability. EGCG is one of the most studied and most active natural antioxidants. It is isolated from green tea and it demonstrates a large spectrum of biological activities, including antioxidant [43], chemopreventive, and chemotherapeutic actions in cellular and animal models of cancer [58]. Many studies have demonstrated the preventive capacity of EGCG on oxidative damage to biomolecules $[59,60]$. Sugisawa et al showed that physiological concentrations of EGCG prevent the effect of ROS-induced chromosomal damage [61].

\subsubsection{Pro-oxidant character of antioxidants}

In addition to their beneficial health effects due to free radical scavenging ability, the natural antioxidants (Vitamin C, Vitamin E, carotenoids and polyphenols) may exert prooxidant activities at higher doses and under specific conditions [5]. Vitamin C reduces $\mathrm{Fe}^{3+}$ to $\mathrm{Fe}^{2+}$ which reacts either with $\mathrm{O}_{2}$, according to reaction (22), or with 
hydrogen peroxide resulting in formation of superoxide anions and highly reactive hydroxyl radicals $[62,63]$ according to reaction $(23)$.

$$
\begin{aligned}
& \mathrm{Fe}^{3+}+\mathrm{AscH}^{-} \rightarrow \mathrm{AscH}^{\bullet}+\mathrm{Fe}^{2+} \\
& \mathrm{Fe}^{2+}+\mathrm{O}_{2} \rightarrow \mathrm{Fe}^{3+}+\mathrm{O}_{2}^{\bullet-} \\
& \mathrm{Fe}^{2+}+\mathrm{H}_{2} \mathrm{O}_{2} \rightarrow \mathrm{Fe}^{3+}+\mathrm{OH}^{-}+\mathrm{OH}^{\bullet}
\end{aligned}
$$

In the case of polyphenols (like flavonoids) the prooxidant activity can be explained by a mechanism associated with the formation of quinones [64]. Quinones may either redox cycle or undergo Michael addition (this can lead to protein thiol depletion with associated loss of protein function). The net result of redox cycling is a chain reaction producing superoxide anion $\left(\mathrm{O}_{2}{ }^{--}\right)$and consuming reducing equivalents in the form of $\mathrm{NAD}(\mathrm{P}) \mathrm{H}$ as well as molecular oxygen. In the Chapter 3 and 4 of this thesis, the prooxidant effects of catechols and naphthalenediols were tested.

\subsection{OXIDATIVE STRESS AND DISEASES ASSOCIATED WITH INCREASED OXIDATIVE STRESS}

Oxidative stress can be defined as an imbalance between the levels of antioxidants and prooxidants in favour of prooxidants. The widely accepted definition of oxidative stress was given by Sies in 1985 [65]: oxidative stress represents "the disturbance in the prooxidant and antioxidant balance in favour of the former, leading to potential damage".

Oxidative stress occurs when the generation of ROS in a system exceeds the ability of the antioxidant defense system to deactivate and eliminate them $[65,66,67]$. This imbalance can result from a reduction of antioxidant capacity (depletions of dietary antioxidants or mutations in antioxidant enzymes) or from an excess of ROS. The 
increase in free radicals in the human body (e.g. due to exposure to toxins and drugs, or activation of phagocytes in chronic inflammatory diseases) is one of the most common causes of oxidative stress and relevant to human diseases [5]. In the case of mild oxidative stress, tissues respond by making more antioxidants in an attempt to restore the balance (e.g. increased SOD synthesis [68], upregulation of GSH [69], etc.).

The accumulation of ROS causes damage to all cellular components (DNA, lipids, proteins, and carbohydrates) [66]. This damage can have additive effects if is not properly repaired resulting in cellular dysfunction and the promotion of various diseases such as cancer [70], cardiovascular disease [71], diabetes [72] neurodegenerative diseases (Parkinson's disease (PD), Alzheimer disease) [5], ischemia-reperfusion injury [73, 74] and aging [75-77].

\subsection{THE DESIGN OF SYNTHETIC ANTIOXIDANTS}

Oxidative stress can be implicated either in the origin of a disease or in the pathology of the disease. Therefore, an antioxidant treatment should delay or prevent the onset of that disease or can decrease the oxidative damage with therapeutic benefits [78].

Considerable effort has been made in the last ten years to design and develop novel therapeutic antioxidants. The investigation of structure-activity relationships for antioxidants and the absorption-distribution-metabolism-excretion-toxicity (ADMET) studies are of significance in the strategy to design new radical scavenging antioxidants [79].

Many groups have focused on the rational design of new antioxidants. Two types of strategies have been used in designing new antioxidants. The first is to modify the 
existing antioxidants to improve their activity (for example, the $\alpha$-tocopherol analogues, 4-thiaflavans) [80-83]. The second strategy starts with the design of a completely new antioxidant (such as hydroxyphenylurea derivatives, 6-substituted-2,4-dimethyl-3pyridinols) $[84,85]$.

In 1980, Burton and Ingold proposed a structure-activity relationship (SAR) for $\alpha$-tocopherol $[86,87]$. They demonstrated that $\alpha$-tocopherol is a superb chain-breaking antioxidant by measuring its reactivity toward peroxyl radicals. Their studies demonstrated the steric and stereoelectronic effects that stabilized the phenoxyl radical formed by reaction of $\alpha$-tocopherol with peroxyl radicals. The overlap between the $2 p$ lone electron pair on the para ether oxygen and the aromatic $\pi$ system is important in stabilization. This overlap is maximized by contraction of a six-membered heterocyclic ring of $\alpha$-tocopherol to a five-membered ring (2,3-dihydrobenzofuran) (Figure 1.2) [87]. Thus, new tocopherol analogues with higher antioxidant activity were proposed. One of the most studied is probucol, obtained by substitution of methyls ortho to the hydroxyl with tert-butyl groups (Figure 1.2) [88,89]. 


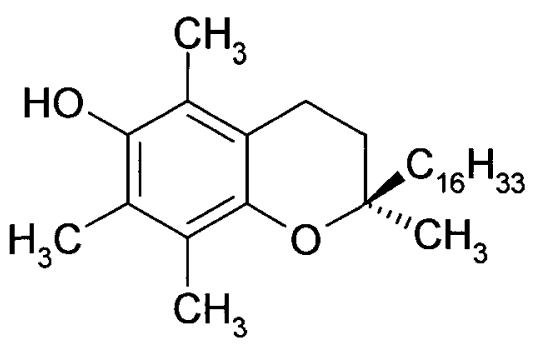<smiles></smiles>

$\alpha$ - tocopherol

$\alpha$ - tocopherol analogue<smiles>CC(C)(Sc1cc(C(C)(C)C)c(O)c(C(C)(C)C)c1)Sc1cc(C(C)(C)C)c(O)c(C(C)(C)C)c1</smiles>

Figure 1.2. Structure of $\alpha$-tocopherol, an analogue of $\alpha$-tocopherol and probucol.

It is known that there are three possible mechanisms by which a "chain-breaking antioxidants" can deactivate a free radical. Assuming the attacking radical is a peroxyl radical ( $\left.\mathrm{ROO}^{\circ}\right)$ the mechanisms are:

a) Hydrogen Atom Transfer (HAT) - an H-atom is transferred from $\mathrm{ArOH}$ to the peroxyl radical, according to the reaction [90]

$$
\mathrm{ArOH}+\mathrm{ROO}^{\bullet} \rightarrow \mathrm{ArO}^{\bullet}+\mathrm{ROOH}\left(\mathrm{ArO}^{\bullet} \text { must be stable }\right)
$$

b) Single Electron Transfer (SET) - a radical cation $\left(\mathrm{ArOH}^{+}\right)$is formed which is rapidly deprotonated in solution [90], according to the following reactions:

Electron transfer: $\mathrm{RO}_{2}{ }^{\bullet}+\mathrm{ArOH} \rightarrow \mathrm{RO}_{2}{ }^{-}+\mathrm{ArOH}^{+}$

Deprotonation equilibrium: $\mathrm{ArOH}^{+}+\mathrm{H}_{2} \mathrm{O} \rightarrow \mathrm{ArO}^{\bullet}+\mathrm{H}_{3} \mathrm{O}^{+}$

Hydroperoxide formation: $\mathrm{RO}_{2}^{-}+\mathrm{H}_{3} \mathrm{O}^{+} \rightarrow \mathrm{ROOH}+\mathrm{H}_{2} \mathrm{O}$ 
The overall reaction is: $\mathrm{RO}_{2}{ }^{\bullet}+\mathrm{ArOH} \rightarrow \mathrm{ROOH}+\mathrm{ArO}^{\bullet}$ identical to that of the HAT mechanism.

c) Sequential proton loss electron transfer (SPLET) - ArOH loses a proton and forms the anion $\mathrm{ArO}^{-}[91,92]$, according to the equation:

$$
\mathrm{ArOH} \rightleftarrows \mathrm{ArO}^{-}+\mathrm{H}^{+}
$$

This is followed by Single Electron Transfer and formation of the peroxyl anion, according to the equation:

$$
\mathrm{ArO}^{-}+\mathrm{RO}_{2}^{\bullet} \rightarrow \mathrm{ArO}^{\bullet}+\mathrm{ROO}^{-}
$$

When $\mathrm{ROO}^{-}$is protonated the product is identical to HAT and SET. All three mechanisms, HAT, SET and SPLET can occur in parallel but one or another is favoured based on rates of reactions. The rate of reaction will strongly correlate with the Bond Dissociation Enthalpy (BDE) of the O-H bond in the case of the HAT mechanism, with the Ionization Potential (IP) for the SET mechanism, and with the $\mathrm{pK}_{\mathrm{a}}$ for the SPLET mechanism, which requires the formation of anion. It was suggested that in most reactions of phenolic antioxidants with free radicals, H-atom transfer is predominant [90]. Recent work indicates that the reactions a) and c) are competitive [91].

Therefore, the ability to predict and calculate the BDE of the $\mathrm{O}-\mathrm{H}$ bond and the $\mathrm{pKa}$ of the parent compound could be very useful in designing effective antioxidants.

Chapter 2 of this thesis presents, in detail, a rational strategy for the design of chain-breaking antioxidants. The starting point in the design is an analysis of the structure of Vitamin E. 


\subsection{HYPOTHESIS}

The following hypotheses were tested in the thesis:

1) that $\mathrm{BDE}$ can be used to predict the antioxidant reactivity of molecules containing a weak $\mathrm{OH}$ bond [90]. Molecules should have a BDE within the "design window" of 68$75 \mathrm{kcal} / \mathrm{mol}$. The weaker the $\mathrm{OH}$ bond of the antioxidant, the faster will be the reaction with free radicals (e.g. peroxyl radicals).

2) in the case of synthetic catechols (compounds with two OH groups) a low BDE for the first exchangeable $\mathrm{H}$-atom $\left(\mathrm{BDE}_{1}\right.$ is for catechol $\rightarrow$ semiquinone) will favour the antioxidant character. A high $\mathrm{BDE}$ for the second exchangeable $\mathrm{H}$-atom $\left(\mathrm{BDE}_{2}\right.$ is for semiquinone $\rightarrow$ quinone) makes the formation of the quinone more difficult.

3) naphthalenediols, which are capable of forming the corresponding naphthoquinones, are relatively cytotoxic whereas those which cannot are relatively non-toxic. These compounds show promise as cytoprotective antioxidants.

These hypotheses are based on the following observations: The experimental $\mathrm{BDE}$ of vitamin $\mathrm{E}$ was found to be $77 \mathrm{kcal} \mathrm{mol}^{-1}$ [28]. Since the ascorbate ion has a BDE of $68.5 \mathrm{kcal} \mathrm{mol}^{-1}$ [93] this requires that an antioxidant (ArOH) have a BDE higher than this value in order for ascorbate to regenerate the synthetic ArOH. Therefore, it is hypothesized that molecules with a BDE within the "design window" of $68-75 \mathrm{kcal} \mathrm{mol}^{-1}$ will react fast with free radicals (DPPH radicals and superoxide produced in cells). The weaker the $\mathrm{OH}$ bond of the antioxidant, the faster will be the reaction with free radicals (e.g. peroxyl radicals). (Chapter 2).

Chapter 3 shows that catechols, although they fit in the design window, have a serious flaw in that they tend to form toxic quinones. This led to a redesign of the 
molecules so as to increase $\mathrm{BDE}_{2}$. For this purpose it was chosen the family naphthalenediols.

Chapter 4 shows that the $\mathrm{BDE}_{2}$ of naphthalenediols is relevant to the formation of the corresponding quinones and this can be used as a predictor of toxicity. The naphthalenediols tested have a $\mathrm{BDE}_{1}$ within the "design window" of $68-75 \mathrm{kcal} \mathrm{mol}^{-1}$.

\subsection{SUMMARY OF AIMS AND OBJECTIVES}

The main objective of this work is to create novel synthetic antioxidants which are superior to vitamin $\mathrm{E}$ in correlation to its effectiveness in deactivating free radicals generated in living systems, mainly peroxyl radicals $\left(\mathrm{ROO}^{\circ}\right)$.

The first aim of this thesis is a systematic design of new antioxidants using vitamin $\mathrm{E}$ as a starting point in order to develop an optimum antioxidant for use in biological systems. Two generations of molecules were designed and tested: a catechol family and a naphthalenediol family.

The second aim of this thesis is the testing of the novel synthetic compounds for their reactivity in chemical solvent (using the 2,2-diphenyl-1-picrylhydrazyl free radicals - DPPH) and in cultured human leukemia cells (HL-60) for the ability to quench free radicals. I also examined the correlation between calculated BDE values and $\log \mathrm{k}$, the second-order rate constant (DPPH assay) as well as the correlation between BDE and $\mathrm{IC}_{50}$ (the concentration of antioxidant necessary to suppress $50 \%$ of the hydroperoxyl radicals produced).

The third aim of this thesis is the testing of the new antioxidants for cytotoxicity and cytoprotection against oxidative stress induced by various stressors (menadione and 
2,2'-azobis (2-amidinopropane) hydrochloride - AAPH) in an adherent clone of rat pheochromocytoma (PC12-AC) cells. The effect of added ascorbate on the cytotoxicity of synthetic catechols and naphthalenediols was examined. Toxicity and protective data were combined to create a measure of the cytoprotective range for each compound. Theoretical calculations were used to see how the toxic or protective effects can be related to molecular structure. The studies of cytotoxicity and cytoprotection of the promising synthetic antioxidants were extended to primary cell culture (neurons) to see if the conclusions derived from PC12-AC cells are more general and whether animal trials should be pursued. The known antioxidant (-)-epigallocatechin gallate (EGCG) from green tea was used for comparison in all studies.

\subsection{REFERENCES}

1. Fridovich, I. (1978) The biology of oxygen radicals. Science 201, 875-880.

2. Fridovich, I. (1998) Oxygen toxicity: a radical explanation. J. Exp. Biol. 201, 12031209.

3. Brenneisen, P., Wenk, J., Klotz, L.O., Wlaschek, M., Briviba, K., Krieg, T., Sies, H., Scharffetter-Kochanek, K., (1998) Central role of ferrous/ferric iron in the ultraviolet B irradiation- mediated signaling pathway leading to increased interstitial collagenase (matrix-degrading metalloprotease (MMP)-1) and stromelysin-1 (MMP-3) mRNA levels in cultured human dermal fibroblasts. J. Biol. Chem. 273, 5279-5287.

4. van der Vaart, H., Postma, D. S., Timens, W., and ten Hacken, N. H. T. (2004) Acute effects of cigarette smoke on inflammation and oxidative stress: a review. Thorax 59, $713-21$ 
5. Halliwell, B., and Gutteridge, J. M. C. (1999) Free Radicals in Biology and Medicine, Oxford University Press: Oxford.

6. Halliwell B, and Gutteridge JMC. Cross CE. (1992) Free radicals, antioxidants, and human disease: where are we now? J. Lab. Clin Med. 119, 598-620.

7. Barja, J. (2002) Endogenous oxidative stress: relationship to aging, longevity and caloric restriction. Ageing Res. Rev. 1, 394-411.

8. Halliwell, B., and Gutteridge, J. M. C. (1986) Oxygen free radicals and iron in relation to biology and medicine: some problems and concepts. Arch. Biochem. Biophys. 246, $501-514$

9. McCord, J. M., and Fridovich, I. (1970) The utility of superoxide dismutase in studying free radical reactions. II the mechanism of the mediation of cytochrome c reduction by a variety of electron carriers. J. Biol. Chem. 245, 1374-1377.

10. Yu, B.P. (1994) Cellular defences against damage from reactive oxygen species. Physiol. Rev. 74, 139-162.

11. Harris, E. D. (1992) Regulation of antioxidant enzymes. FASEB J. 6, 2675-2683.

12. Imlay, J. A., Chin, S. M., and Linn, S. (1988) Toxic DNA damage by hydrogen peroxide through the Fenton reaction in vivo and in vitro. Science 240, 640-642.

13. Pryor, W. A. (1986) Oxy-radicals and related species: their formation, lifetimes, and reactions. Annu. Rev. Physiol. 48, 657-667.

14. Sies, H. (1993) Strategies of antioxidant defense. Eur. J. Biochem., 215, 213-219. 15. Haber, F., and Weiss, J. (1934) The catalytic decomposition of hydrogen peroxide by iron salts. Proc. R. Soc. Lond. Ser. A 1,332-351. 
16. Girotti, A.W. (1998) Lipid hydroperoxide generation, turnover, and effector action in biological systems. J. Lipid Res. 39, 1529-1542.

17. van Acker, S. A. B. E., Luc M.H.K., and Aalt, B. (1993) Molecular pharmacology of Vitamin E: structural aspects of antioxidant activity. Free Rad. Biol. Med. 15, 311-328.

18. Halliwell, B., and Gutteridge, J. M. C. (1995) The definition and measurement of antioxidants in biological systems. Free Rad. Biol. Med.18, 125-126.

19. Halliwell B. (1996) Antioxidants in human health and disease. Annu. Rev. Nutr.16, $33-50$.

20. Fridovich, I. (1986). Superoxide dismutases. Meth. Enzymol. 58, 61-97.

21. McCord, J. M., and Fridovich, I. (1969) Superoxide dismutase. An enzymatic function for erythrocuprein (hemocuprein). J. Biol. Chem. 244, 6056-6063.

22. Gregory, E. M., and Fridovich, I. (1973) Induction of superoxide dismutase by molecular oxygen. J. Bacteriol. 114, 5443-5447.

23. Rice-Evans, C.A., and Burdon, R. H. (1994) Free radical damage and its control. New Comprehensive Biochemistry, 28, Elsevier Science B.V., Amsterdam, the Netherlands.

24. Lawrence, R. A., and Burk, R. F. (1976) Glutathione peroxidase activity in selenium deficient rat liver. Biochem. Biophys. Res. Commun. 71, 952-959.

25. Fisher, A. B., Dodia, C., Manevich, Y., Chen, J-W., and Feinstein, S. I. (1999) Phospholipid hydroperoxides are substrates for non-selenium glutathione peroxidase. $J$ Biol Chem. 274, 21326-21334.

26. Ursini, F. M., Maiorino, M., and Gregolin, C. (1985) The selenoenzyme phospholipid hydroperoxide glutathione peroxidase. Biochim. Biophys. Acta 839, 62-70. 
27. Burton, G. W., and Ingold, K. U. (1981) Autoxidation of biological molecules. The antioxidant activity of vitamin $\mathrm{E}$ and related chain-breaking phenolic antioxidants in vitro. J. Am. Chem. Soc. 1113, 6472-6477.

28. Burton, G. W., and Ingold, K. U. (1986) Vitamin E: Application of the principles of physical organic chemistry to the exploration of its structure and function. Acc. Chem. Res. 19, 194-201.

29. Salgado, J., Villalian, J., and Gomez-Fernandez, J. C. (1993) Alpha-tocopherol interacts with natural micelle-forming single-chain phospholipids stabilizing the bilayer phase. Arch. Biochem. Biophys. 306, 368-376.

30. Bradford, A., Atkinson, J., Fuller,N., and R. P. Rand, R. P. (2003) The effect of vitamin $\mathrm{E}$ on the structure of membrane lipid assemblies. J. Lipid Res. 44, 1940-1945.

31. Machlin, L. J., and Bendich, A. (1987) Free radical tissue damage: Protective role of antioxidant nutrients. FASEB J. 1, 441-445.

32. Niki, E. (1987) Interaction of ascorbate and $\alpha$-tocopherol. Ann. N. Y. Acad. Sci. 498, 186-198.

33. Rose, R.D., and Bode, A. M. (1993) Biology of free radical scavengers: An evaluation of ascorbate. FASEB J. 7, 1135-1142.

34. Mendiratta, S., Qu, Z. C., and May, J. M. (1998) Enzyme-dependent ascorbate recycling in human erythrocytes: role of thioredoxin reductase. Free Rad. Biol. Med. 25, 221-228.

35. Vethanayagam, J. C., Green, E. H., Rose, R.C., and Bode, A. M. (1999) Glutathionedependent ascorbate recycling activity of rat serum albumin. Free Rad. Biol. Med. 26, 1591-1598. 
36. Wefers, H., and Sies, H. (1983) Oxidation of glutathione by the superoxide radical to the disulfide and the sulfonate yielding singlet oxygen. Eur. J. Biochem. 137, 29-36.

37. Packer, J. E., Slater, T. F., and Willson, R. L. (1979) Direct observation of a free radical interaction between vitamin E and vitamin C. Nature 278, 737-738.

38. Frei, B., Stocker, R., and Ames, B. N. (1988) Antioxidant defences and lipid peroxidation in human blood plasma. Proc. Natl. Acad. Sci. USA 85, 9748-9752.

39. Scarpa, M., Rigo, A., Maiorino, M., Ursini, F., and Gregolin, C. (1984) Formation of $\alpha$-tocopherol by ascorbate during peroxidation of phosphatidyl choline liposomes. An electron paramagnetic resonance study. Biochim. Biophys. Acta 801, 215-219.

40. Niki, E., Kawakami, A., Saito, M., Yamamoto, Y., Tsuchiya, J., and Kamiya, Y. (1985) Effect of phytyl side chain of vitamin E on its antioxidant activity. J. Biol. Chem. 260, 2191-2196.

41. Bains, J. S., and Shaw, C. A. (1997) Neurodegenerative disorders in humans: the role of glutathione in oxidative stress -mediated neuronal death. Brain Res. Reviews 25, 335358.

42. Varga, V., Jenei, Zs., Janaky, R., Saransaari, P., and Oja, S. S. (1997) Glutathione is an endogenous ligand of rat brain N-methyl- D-aspartate (NMDA) and 2-amino-3hydroxy-5- methyl-4-isoxazolepropionate (AMPA) receptors. Neurochem. Res. 22, 1165-1171.

43. Rice-Evans, C.A., Miller, N. J., and Paganga, G. (1996) Structure-antioxidant activity relationship of flavonoids and phenolic acids. Free Rad. Biol. Med. 20, 933.

44. Chen, Y. Zheng, R., Jia, Z., and Ju, Y. (1990) Flavonoids as superoxide scavengers and antioxidants. Free Rad. Biol. Med. 9, 19-21. 
45. Robak, J., and Gryglewski, R. J. (1988) Flavonoids are scavengers of superoxide anions. Biochem. Pharmacol. 37, 837-841.

46. Mira, L., Fernandez, M. T., Santos, M., Rocha, R., Florencio, M. H., and Jennings, K. R. (2002) Interaction of flavonoids with iron and copper ions: a mechanism for their antioxidant activity. Free Rad. Res. 36, 1199-1208.

47. Spencer, J. P. E., Abd El Mohsen, M. M., and Rice-Evans, C. (2004) Cellular uptake and metabolism of flavonoids and their metabolites: implications for their bioactivity. Arch. Biochem. Biophys. 423, 148-161.

48. Lopez-Revuelta, A., Sanchez-Gllego, J., Harnandez-Hernandez, A., Sanchez-Yahue, J., and Llanillo, M. (2006) Membrane cholesterol contents influence the protective effects of quercetin and rutin in erythrocytes damaged by oxidative stress. Chem. Biol. Int. 161 . 79-91.

49. Schroeter, H., Spencer, J. P., Rice-Evans, C., and Williams, R. J. (2001) Flavonoids protect neurons from oxidized low density lipoprotein-induced apoptosis involving c-Jun N-terminal kinase (JNK), c-Jun and caspase-3. Biochem. J. 358, 547-557.

50. Williams, R. J., Spencer, J. P. E., and Rice-Evans, C. (2004) Flavonoids: Antioxidants or signalling molecules? Free Rad. Biol. Med. 36, 838-849.

51. Matter, W. F., Brown, R. F., and Vlahos, C. J. (1992) The inhibition of phosphatidylinositol 3-kinase by quercetin and analogs. Biochem. Biophys. Res. Commun. 186, 624-631.

52. Barzilai, A., and Rahamimoff, H. (1983) Inhibition of Ca2 +-transport ATPase from synaptosomal vesicles by flavonoids. Biochim. Biophys. Acta 730, 245-254. 
53. Revuelta, M. P., Cantabrana, B., and Hidalgo, A. (1997) Depolarizationdependent effect of flavonoids in rat uterine smooth muscle contraction elicited by $\mathrm{CaCl2}$. Gen . Pharmacol. 29, 847-857.

54. Soriani, M., Rice-Evans, C., and Tyrrell, R. M. (1998) Modulation of the UVA activation of haem oxygenase, collagenase and cyclooxygenase gene expression by epigallocatechin in human skin cells. FEBS Lett. 439, 253-257.

55. Kim, H.K., Cheon, B.S., Kim, Y. H., Kim, S.Y., and Kim, H.P. (1999) Effects of naturally occurring flavonoids on nitric oxide production in the macrophage cell line RAW 264.7 and their structure-activity relationships. Biochem. Pharmacol. 58, 759-765. 56. Krol, W., Czuba, Z.P., Threadgill, M.D., Cunningham, B.D., and Pietsz, G. (1995) Inhibition of nitric oxide (NO•) production in murine macrophages by flavones. Biochem. Pharmacol. 50, 1031-1035.

57. Rahman, I., Yang, S.R., and Biswas, S. K.(2006) Current concepts of redox signaling in the lungs. Ant. Redox Sign. 8, 681-689.

58. Kanner, J., Frankel, E., Granit, R., German, B., and Kinsella, J. E. (1994). Natural antioxidants in grapes and wines. J. Agric. Food Chem. 42, 64-69.

59. Johnson, M. K., and Loo, G. (2000) Effects of epigallocatechin gallate and quercetin on oxidative damage to cellular DNA. Mutat. Res. 459, 211-218.

60. Yamanaka, N., Oda, O., and Nagao, S. (1997) Green tea catechins such as (-)epicatechin and (-)-epigallocatechin accelerate $\mathrm{Cu} 2+$-induced low density lipoprotein oxidation in propagation phase. FEBS Lett. 401, 230-234. 
61. Sugisawa, A., and Umegaki, K. (2002) Physiological concentrations of (-)epigallocatechin-3-O-gallate (EGCG) prevent chromosomal damage induced by reactive oxygen species in WIL2-NS cells. J. Nutr. 132, 1836-1839.

62. Halliwell, B., Wasil, M., and Grootvels, M. (1987) Biologically significant scavenging of the myeloperoxidase-derived oxidant hypochlorus acid by ascorbic acid. FEBS Lett. 213, 15-19.

63. Samuni, A., Aronovitch, J., Godinger, D., Chevion, M., and Czapski, G. (1983) On the cytotoxicity of vitamin $\mathrm{C}$ and metal ions. A site-specific Fenton mechanism. Eur. $J$. Biochem. 137, 119-124.

64. Brunmark, A., and Cadenas, E. (1989) Redox and addition chemistry of quinoid compounds and its biological implications. Free Rad. Biol. Med. 7, 435-477.

65. Sies, H. (1985) Oxidative stress. Toronto, Academic Press.

66. Sies, H. (1986) Biochemistry of oxidative stress. Angew. Chem. Int. Ed. Engl. 25, $1058-1071$.

67. Sies, H., and Cadenas, E. (1985) Oxidative stress: damage to intact cells and organs. Phil. Trans. of the Royal Society of London, Series B: Biol. Sci. 311, 617-631.

68. Iqbal, J., Clerch, L. B., Hass, M. A., Frank, L., and Massaro, D. (1989) Endotoxins increases lung $\mathrm{Cu}, \mathrm{Zn}$ superoxide dismutase mRNA: $\mathrm{O}_{2}$ raises enzyme synthesis. J. Am. Physiol. 257, L61-64.

69. Han, S.-K., Mytilineou, C., and Cohen, G. (1996) L-DOPA up-regulates glutathione and protects mesencephalic cultures against oxidative stress. J. Neurochem. 66, 501-510. 70. Klaunig, J. E., and Kamendulis, L. M. (2004) The role of oxidative stress in carcinogenesis. Ann. Rev. Pharm. Toxicol. 44, 239-267. 
71. MacCarthy, P. A., and Shah, A. M. (2003) Oxidative stress and heart failure. Cor. artery dis. 14, 109-113.

72. Yan, S. D., Schmidt A. M., Anderson, G. M., Zhang, J., Brett, J., and Zou, Y. S. (1994) Enhanced cellular oxidant stress by the interaction of advanced glycation end products with their receptors/binding proteins. J. Biol. Chem. 269, 9889-9897.

73. Bolli, R. (1988) Oxygen-derived free radicals and postischemic myocardial dysfunction ("stunned myocardium"). J. Am. Coll. Cardiol. 12, 239.249.

74. Zweier, J. L., Flaherty, J. T., and Weisfeldt, M. L. (1987) Direct measurement of free radical generation following reperfusion of ischemic myocardium. Proc. Natl. Acad. Sci. U.S.A. 84, 1404-1407.

75. Biesalski, H. K. (2002) Free radical theory of aging. Curr. Opin. Clin. Nutr. Metabol. Care 5, 5-10.

76. Berlett, B. S., and Stadtman, E. R. (1997) Protein oxidation in aging, disease, and oxidative stress. J. Biol. Chem. 272, 20313-20316.

77. Ames, B. N., Shigenaga, M. K., and Hagan, T. (1993) Oxidants, antioxidants, and the degenerative diseases of aging. Proc. Natl. Acad. Sci. USA, 90, 7915-7922.

78. Halliwell, B., and Whiteman, M. (2004) Measuring reactive species and oxidative damage in vivo and in cell culture: how should you do it and what the results mean? British J. Pharm. 142, 231-255.

79. Zhang, H-Y. (2005) Structure-activity relationship and rational design strategies for radical scavenging antioxidants. Curr. Comp.-Aided Drug Des. 1, 257-273.

80. Watanabe, A., Noguchi, N., Fujisawa, A., Kodama, T, Tamura, K., Cynshi, O., and Niki, E. (2000) Stability and reactivity of aryloxyl radicals derived from a novel 
antioxidant BO-653 and related compounds. Effects of substituent and side chain in solution and membranes. J. Am. Chem. Soc. 122, 5438-5442.

81. Menichetti, S., Aversa, M. C., Cimino, F., Contini, A., Viglianisi, C., and Tomaino, A. (2005) Synthesis and "double-faced" antioxidant activity of polyhydroxylated 4thiaflavans. Org. Biol. Chem. 3, 3066-3072.

82. Noguchi, N., and Niki, E. (2000) Phenolic antioxidants: a rationale for design and evaluation of novel antioxidant drug for artherosclerosis. Free Rad. Biol. Med. 28, 15381546.

83. Noguchi, N., Iwaki, Y., Takahashi, M., Komuro, E., Kato, Y., Tamura, K., Cynshi, O., Kodama, T, and Niki, E. (1997) 2,3-Dihydro-5-hydroxy-2,2-dipentyl-4,6-ditertbutylbenzofuran: design and evaluation as a novel radical-scavenging antioxidant against lipid peroxidation. Arch. Biochem Bioph. 342, 236-243.

84. Nakao, K., Shimizu, R., Kubota, H., Yasuhara, M., Hashimura, Y., Suzuki, T., Fujita, T., and Ohmizu, H. (1998) Quantitative structure - activity analyses of novel hydroxyphenylurea derivatives as antioxidants. Bioorg. Med. Chem.6, 849-868.

85. Wijtmans, M., Pratt, D.A., Brinkhorst, J., Serwa, R., Valgimigli, L., Pedulli, G. F., and Porter, N.A. (2004) Synthesis and reactivity of some 6-substituted-2,4-dimethyl-3pyridinols, a novel class of chain-breaking antioxidants. J. Org. Chem. 69, 9215-9223 86. Burton, G. W.; LePage, Y.; Gabe, E. J.; Ingold, K. U. (1980) Antioxidant activity of vitamin $\mathrm{E}$ and related phenols. Importance of stereoelectronic factors. J. Am. Chem. Soc. $102,7791-7792$. 
87. Burton, G. W.; Hughes, L.; Ingold, K. U. (1983) Antioxidant activity of phenols related to vitamin E. Are there chain-breaking antioxidants better than $\alpha$-tocopherol? J. Am. Chem. Soc. 105, 5950-5951.

88. Barnhart, R.L., Bush, S. J., and Jackson, R. L. (1989) Concentration-dependent antioxidant activity of probucol in low density lipoproteins in vitro: probucol degradation precedes lipoprotein oxidation. J. Lipid Res. 30, 1703-1710.

89. Bittolo-Bon, B., Cazzolato, G., and Avogaro, P. (1991) Probucol protects lowdensity lipoproteins from in vitro and in vivo oxidation. Pharmacol. Res. 29, 337-344.

90. Wright, J. S., Johnson, E. R., and DiLabio, G. A. (2001) Predicting the activity of phenolic antioxidants. J. Am. Chem. Soc. 12, 1173-1183.

91. Wright, J. S., Rowley, C. N., and Chepelev, L. L. (2005) A 'universal' B3LYP-based method for gas-phase molecular properties: Bond dissociation enthalpy, ionization potential, electron and proton affinity and gas-phase acidity. Mol. Phys. 103, 815-823.

92. Litwinienko, G, and Ingold, K. U. (2005) Abnormal Solvent Effects on Hydrogen Atom Abstraction. 3. Novel Kinetics in Sequential Proton Loss Electron Transfer Chemistry. J. Org. Chem. 70, 8982-8990.

93. Dilabio, G. A., Pratt, D. A., LoFaro, A. D., and Wright, J. S. (1999) Theoretical study of $\mathrm{X}-\mathrm{H}$ bond energetics $(\mathrm{X}=\mathrm{C}, \mathrm{N}, \mathrm{O}, \mathrm{S})$ : Application to substituent effects, gas phase acidities and redox potentials. J. Phys. Chem. A 103, 1653-1661. 


\title{
Chapter 2
}

Novel synthetic antioxidants as free radicals scavengers:

Design strategy and testing with DPPH and HL-60 cell

\author{
cultures
}




\subsection{INTRODUCTION}

Reactive oxygen species (ROS) play major roles in various diseases, in aging and age-related diseases. [1,2]. Depending on their chemical structure, ROS can be very reactive and toxic, leading to oxidative damage of lipids, proteins, and nucleic acids and even death if their production is not well controlled [3-6]. In the case of oxidative stress, when the production of free radicals exceeds the cells defense systems (such as superoxide dismutase, catalase, the glutathione peroxidase system, and the vitamin E/ascorbic acid system), the use of an antioxidant therapy such as synthetic antioxidants (radical scavengers) would be effective [7-9]. Vitamin $\mathrm{E}$ is one of the most important chain-breaking, lipid-soluble antioxidant in biological membrane capable of quenching the propagation of free-radical reactions $[10,11]$. Many other chemical structures have been used to design novel radical scavengers, but the structure of $\alpha$-tocopherol has often served as a starting point for the design of potent synthetic free-radical scavengers [12]. Over the past several years, considerable progress has been made in understanding what makes a molecule an effective antioxidant and developing methods to design novel and non-toxic antioxidant molecules [13].

In the previous chapter, I have discussed the process of lipid peroxidation by which lipid molecules are converted into lipid hydroperoxides (ROOH). The mechanism of lipid peroxidation involves 3 reactions: initiation, propagation and termination [12]. The control of initiation and propagation reactions is a general approach in designing a synthetic antioxidant. 
In this chapter, I am focused on the design of antioxidant molecules that can interrupt the chain reaction of lipid peroxidation, according to the reaction

$$
\mathrm{RO}_{2}^{\bullet}+\mathrm{ArOH} \rightarrow \mathrm{ROOH}+\mathrm{ArO}^{\bullet}
$$

There are three possible mechanisms (discussed in Chapter 1) for deactivation of peroxyl radicals: Hydrogen Atom Transfer (HAT) correlated with the Bond Dissociation Enthalpy (BDE) of the O-H bond, Single Electron Transfer (SET) [14] correlated with Ionization Potential; and Sequential Proton Loss Electron Transfer (SPLET) correlated with the $\mathrm{pK}_{\mathrm{a}}$ [15]. It was suggested that in most reactions of phenolic antioxidants with free radicals, $\mathrm{H}$-atom transfer is predominant [14]. Therefore, prediction and calculation of the $\mathrm{BDE}$ of the $\mathrm{OH}$ bond could be a very useful tool in the designing effective antioxidants.

One of the best lipid-soluble chain-breaking antioxidants is $\alpha$-tocopherol ( $\alpha$ $\mathrm{TOH}$ ), a component of vitamin $\mathrm{E}$ which intercepts peroxyl radicals generated in lipid peroxidation with a rate constant of $10^{6} \mathrm{M}^{-1} \mathrm{~s}^{-1}[16]$, according to:

$$
\alpha-\mathrm{TOH}+\mathrm{RO}_{2}{ }^{\bullet} \rightarrow \alpha-\mathrm{TO}^{\bullet}+\mathrm{ROOH}
$$

Then, the $\alpha$-tocopheroxyl radical reacts with ascorbic acid with the regeneration of $\alpha$ TOH [17-19], according to:

$$
\alpha-\mathrm{TO}^{\bullet}+\mathrm{AscH}^{-} \rightarrow \alpha-\mathrm{TOH}+\mathrm{Asc}^{\bullet-}
$$

The ascorbate radical can then either disproportionate to ascorbate plus dehydroascorbic acid or be reduced back to ascorbic acid by interaction with other reducing species in the cell, such as glutathione or enzyme systems that use NADH and NADPH [20,21]. The BDE for ROO-H is about $88 \mathrm{kcal} / \mathrm{mol}$, so there will be a relatively low barrier for a BDE 
of ArO-H less than $88 \mathrm{kcal} \mathrm{mol}^{-1}$ (the BDE of $\alpha$-tocopherol is approximately $77 \mathrm{kcal}$ $\left.\mathrm{mol}^{-1}\right)$. The antioxidant will react faster with the peroxyl radical, preventing reaction with the substrate (lipid molecules - RH). Phenols with a BDE of $88 \mathrm{kcal} \mathrm{mol}^{-1}$ will react slowly with $\mathrm{RO}_{2}{ }^{*}$, the reaction being thermoneutral. According to the Hammond postulate [22], the rate of reaction of the substrate with peroxyl radical is correlated with the barrier height of an $\mathrm{H}$-atom transfer from $\mathrm{ArOH}$ to $\mathrm{RO}_{2}{ }^{\circ}$. The reaction of $\alpha$-tocopherol with peroxyl radicals is exothermic (low barrier) and much faster since the lower the BDE (the weaker the $\mathrm{OH}$ bond) the faster will be the reaction with free radicals [14]. Based on additivity values it was predicted that the BDE of $\alpha-\mathrm{TOH}$ is -2 (two groups ortho-methyl), 0 (meta-methyl), 0 (phytyl tail) and -6.0 (para-O), giving a predicted BDE of $77 \mathrm{kcal} \mathrm{mol}^{-1}$ in agreement with the calculated BDE [14]. Thus Vitamin E, and any other molecules with a lower BDE than $77 \mathrm{kcal} \mathrm{mol}^{-1}$, are effective chain-breaking antioxidants that prevent lipid peroxidation while phenol is not.

In designing compounds as effective antioxidants, the following parameters have to be considered as relevant [23-26]:

1. The compounds must not contain weak $\mathrm{C}-\mathrm{H}$ bonds because these can form carboncentered radicals by homolytic cleavage. These radicals react fast with molecular oxygen and become chain-propagating radicals, such as $\operatorname{ROO}^{\bullet}[27,28]$.

2. The compounds can have a sulfur, nitrogen or oxygen atom. Sulfur-centered radicals can form $\mathrm{RSOO}^{\bullet}$ radicals [5]. However, molecules involving oxygen-centered radicals are more often studied. The oxygen-centered radicals are stable and don't react with oxygen to form $\operatorname{ArOOO}^{\bullet}$ because the reaction is endothermic by ca. $20 \mathrm{kcal} \mathrm{mol}^{-1}$ [14]. 
3. The compounds should react fast with peroxyl radicals (ROO ${ }^{\circ}$ ). According to equation (1) the $\mathrm{ROO}^{\bullet}$ forms by reaction with $\mathrm{ArOH}$ a bond in $\mathrm{ROO}-\mathrm{H}$ with a BDE of 88 kcal mol ${ }^{-1}$ [29]. Therefore, the BDE of the antioxidant should be below this value for a rapid reaction.

4. Our goal is to design an antioxidant superior to vitamin E. Thus, the compounds should have a BDE value lower than $77 \mathrm{kcal} \mathrm{mol}^{-1}$, the experimental BDE of vitamin E [16].

5. Since the ascorbate ion has a BDE of $68.5 \mathrm{kcal} \mathrm{mol}^{-1}$ [30] this requires that an antioxidant $(\mathrm{ArOH})$ have a $\mathrm{BDE}$ higher than this value in order for ascorbate to regenerate the synthetic ArOH. The useful design window is $68-75 \mathrm{kcal} \mathrm{mol}^{-1}$ [31].

6. The radical $\mathrm{ArO}^{\circ}$ formed should not react with lipid, protein or other biological substrates. The radical should react with vitamin $\mathrm{C}$ or glutathione in order to regenerate the $\mathrm{ArOH}[16]$.

7. The antioxidants should have functional groups that allow them to be transported through cell membranes (for example, by esterifying the $\mathrm{OH}$ groups) and increase the lipid solubility (like the phytyl tail in vitamin E) [19].

To predict a BDE value based on group additivity rules, a set of optimized $\triangle \mathrm{BDEs}$ (BDEs relative to phenol itself) were defined by performing locally dense basis sets (LDBS) calculations [14].

Phenolic antioxidants can contain various functional groups which are electron-donating such as methyl, hydroxy, methoxy, and amino or electron-withdrawing groups such as formyl, acetyl, carboxyl, and ester groups. Table 1 shows the recommended additivity values on the $\mathrm{OH} \mathrm{BDE}$ in phenolic compounds as calculated by Wright et al. [14]. 
Table 2.1. Additive effects on the BDE value in phenolic compounds relative to phenol $(87 \mathrm{kcal} / \mathrm{mol})$.

\begin{tabular}{|l|l|l|l|}
\hline Group & Ortho substitution & Meta substitution & Para substitution \\
\hline $\mathrm{NH}_{2}$ & -11.5 & -0.2 & -9.4 \\
\hline $\mathrm{OCH}_{3}$ & -1.4 & -0.6 & -6.1 \\
\hline $\mathrm{OH}$ & -9.2 & -0.4 & -5.9 \\
\hline $\mathrm{CH}-\mathrm{CH}_{2}$ & -4.0 & -0.2 & -4.7 \\
\hline$-\mathrm{C}\left(\mathrm{CH}_{3}\right)_{3}$ & -2.7 & -0.6 & -2.5 \\
\hline $\mathrm{CH}_{3}$ & -2.0 & -0.4 & -2.5 \\
\hline $\mathrm{Cl}$ & +1 & +1.2 & -1.4 \\
\hline $\mathrm{CN}$ & +3.6 & +2.7 & +2.2 \\
\hline $\mathrm{CHO}$ & +8.0 & +2.2 & +2.4 \\
\hline $\mathrm{COOH}$ & +8.1 & +2.5 & +2.6 \\
\hline
\end{tabular}

For ortho functional groups, both conformational changes and hydrogen bonding must be taken into account. Scheme 2.1 shows the parent catechol and the catechol radical. The $\mathrm{OH}$ bond is broken in the parent molecule and the radical is able to rearrange in order to be stable [32]. In the calculation of the BDE of ortho-substituted catechols, the electronic effect must be taken into account, considering the H-bond of the parent molecule and the $\mathrm{H}$-bond of the radical. For instance, the calculated $\triangle \mathrm{BDE}$ of the ortho-catechol is $(-5.2+4-8=-9.2)$ :

$-5.2 \mathrm{kcal} / \mathrm{mol}$ - electronic effect

$-4 \mathrm{kcal} / \mathrm{mol}$ - contribution of hydrogen bond in parent

$-8 \mathrm{kcal} / \mathrm{mol}$ - contribution of hydrogen bond in radical

Thus, the BDE of a catechol is $77.9 \mathrm{kcal} / \mathrm{mol}$. 


\section{SCHEME 2.1}<smiles></smiles>

A catechol donates its first hydrogen to a radical such as ROO forming the semiquinone (the bond dissociation enthalpy of the diol denoted $\mathrm{BDE}_{1}$ ). Then, the oxidation of semiquinone leads to a quinone $\left(\mathrm{BDE}_{2}\right)$.

\section{SCHEME 2.2}

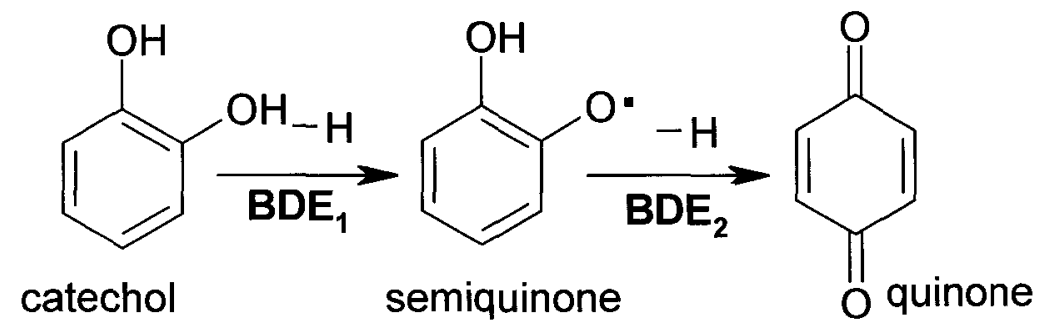

A systematic theoretical investigation of families of antioxidants was started based on knowledge gained in understanding how to predict new and superior target compounds. In this chapter, the design of a series of novel antioxidants with a catechol moiety which have a BDE that falls into or near the design window will be discussed. The objective was to create molecules more effective than a reference compound, vitamin E, as an antioxidant. After the synthesis of promising compounds, I tested them for their capacity to quench free radicals in chemical and biological systems.

The potential antioxidant activity of the new synthetic compounds has been assessed based on two assays: scavenging stable 2,2-diphenyl-1-picrylhydrazyl free radicals (DPPH assay) and inhibiting phorbol 12-myristate 13-acetate (PMA)-induced radical formation in cultured human leukemia cells (HL-60). 
In the DPPH assay, the antioxidants can react with the stable, purple-coloured free radical DPPH, forming the colourless species $\mathrm{DPPH}_{2}$ by $\mathrm{H}$-atom transfer similar to the reaction with peroxyl radicals $[23,32,33]$. The weaker the $\mathrm{OH}$ bond, the faster the reaction of test samples with DPPH radicals [32].

In order to test the newly designed antioxidants for the capacity to scavenge free radicals in cells, I have chosen the HL-60 cell line as a model. HL-60, a human promyelocytic leukemia cell line first isolated by Collins et al in 1977, is a cell model widely used to evaluate the biological activity of a large number of compounds as potential chemopreventive agents capable of inducing cellular differentiation [34-36]. Some of these reagents cause HL-60 cells to differentiate to granulocyte-like cells, others to monocyte/macrophage-like cells [37]. Dimethyl sulfoxide (DMSO)-differentiated cells, by stimulation with PMA, can generate superoxide radicals at a constant rate [3840]. Using cytochrome $C$ as a monitor, the inhibitory capacity of test samples on free radicals was determined. Bhimani et al. have used this system for screening of various potential chemopreventive agents for antioxidant activity through their ability to scavenge free radicals [41]. Novel antioxidant compounds, isolated from bamboo leaves, demonstrated superoxide anion scavenging activities stronger than those of ascorbic acid and $\alpha$-tocopherol [42].

In this chapter, we have tested the hypothesis that the BDE can be used to predict the reactivity of molecules containing a weak $\mathrm{OH}$ bond [14]. Molecules with a $\mathrm{BDE}_{1}$ within the "design window" of $68-75 \mathrm{kcal} / \mathrm{mol}$ will react fast with free radicals. The weaker the $\mathrm{OH}$ bond of the antioxidant, the faster will be the reaction with free radicals (peroxyl radicals). 


\subsection{MATERIAL AND METHODS}

\section{Materials}

RPMI 1640 medium (with L-glutamine and without bicarbonate), Penicillin/Streptomycin solution, Trypan blue solution $(0.4 \%$, liquid, sterile-filtered, cell culture tested), DMSO, Hanks' balanced salt solution (HBSS) epigallocatechin gallate (EGCG), Trolox, propyl gallate, resveratrol, PMA, ethanol, sodium bicarbonate, cytochrome c (from horse heart) were obtained from Sigma Chemical Co. (St. Louis, MO, USA). DPPH was obtained from Northern Sources, Inc. Fetal bovine serum was purchased from Invitrogen (Carlsbad, CA, USA). 2-Hydroxymethyl-4-methoxyphenol $\left(\mathrm{H}_{0}\right)$, 3-Methyl-4-methoxy-1,2-dihydroxybenzene $\quad(\mathrm{H}), \quad$ 4-methoxy-3,5,6trimethylbenzene-1,2-diol (H1), 2,6,7-trimethyl-2,3-dihydrobenzofuran-4,5-diol (H2), benzo[1,3]dioxole-5,6-diol (H3), and 4-methylbenzo[1,3]dioxole-5,6-diol (H4) were synthesized as described by Hussain et al. [30]. All structures were verified in the laboratory of Tony Durst, University of Ottawa by ${ }^{1} \mathrm{H}$ and ${ }^{13} \mathrm{C}$ NMR, as well as by mass spectrometry.

\section{Cell culture}

HL-60, a human promyelocytic leukemia cell line derived by S.J. Collins et al. [35], was purchased from American Type Culture Collection (ATCC). Cells were grown in RPMI 1640 medium supplemented with $10 \%$ heat-inactivated fetal bovine serum, sodium bicarbonate $(2 \mathrm{~g} / \mathrm{L})$ and $1 \%$ Penicillin $(100$ units $/ \mathrm{mL}) /$ Streptomycin $(100 \mu \mathrm{g} / \mathrm{mL})$ solution. Cells were maintained at $37{ }^{\circ} \mathrm{C}$ in a humidified atmosphere $\left(5 \% \mathrm{CO}_{2}\right.$ in air $)$ and passed at a density of approximately $1.5 \times 10^{5}$ cells $/ \mathrm{mL}$ twice a week, with a doubling time of approximately $24 \mathrm{~h}$. Their concentration did not exceed $10^{6}$ cells $/ \mathrm{ml}$. Cell 
numbers and viability were determined by the trypan blue dye $(0.1 \% \mathrm{w} / \mathrm{v})$ exclusion method.

\section{Trypan Blue exclusion method}

To an Eppendorf tube was added $250 \mu \mathrm{L}$ of trypan blue (4\% solution), $150 \mu \mathrm{L}$ PBS and $100 \mu \mathrm{L}$ solution of cells. After 5 - 10 minutes of incubation, the mixture was vortexed and the cells were counted using a hemocytometer. Living cells appeared colorless, while dead cells stained blue. The proportion of live to dead cells in a population following certain manipulations and treatments was determined using this method. A cell that is metabolically alive has a cell membrane that is active and selects the materials that pass into cytoplasm. The membrane of a dead cell has lost this selective capacity and many materials readily pass into the cell.

\section{HL-60 cell differentiation}

HL-60 cells were induced to morphologically differentiate with $1.3 \%$ DMSO [37]. The cells in log phase growth (approximately $10^{6}$ cells $/ \mathrm{mL}$ ) were diluted to 200,000 cells $/ \mathrm{mL}$ and plated in four $175 \mathrm{~cm}^{2}$ flasks $(80 \mathrm{~mL} /$ flask $)$. DMSO was added to the flasks to a final concentration of $1.3 \%$. The effect on viability and proliferation of HL-60 cells was determined every day for seven days of incubation. The rate of superoxide production was measured with the cytochrome c reduction method [36]. Following this treatment, the cells become analogous to neutrophils found in the human immune system and become biological generators of superoxide free radicals by stimulation with PMA. 


\section{Cytochrome C reduction assay}

HL-60 cells were differentiated in culture medium containing 1,3\% DMSO for 5 days. Then the cells were then harvested with centrifugation at $1000 \mathrm{rpm}$ washed twice and resuspended in HBSS. Cells $\left(1 \times 10^{6}\right.$ cells $\left./ \mathrm{mL}\right)$ were plated in 96-well microtiter plates [36]. After preincubation of the cells with the new synthetic compounds for 10 min, free radical formation was induced by the addition of PMA $(1 \mu \mathrm{M})$. Cytochrome $\mathrm{C}$ $(80 \mu \mathrm{M})$ was added in all wells and the plate was incubated at $37{ }^{\circ} \mathrm{C}$ for $30 \mathrm{~min}$. The absorption values were read at $550 \mathrm{~nm}$ in a SpectroMax $340^{\mathrm{PC}}$ microplate reader (Molecular Devices Co., Sunnyvale CA USA). The "Blank" is based on the absorbance of cells only in HBSS in which cytochrome C was added. "Controls" were the absorbance of cells treated with PMA in HBSS and cytochrome C.

\section{DPPH: Stopped-flow kinetics assay}

The tests were done in the laboratory of Dr. Ingold K. at National Research Council (NRC), Canada. All compounds were dissolved in ether, washed with aqueous sodium dithionite, and then re-isolated prior to the kinetic measurements [31]. A solution of $\mathrm{DPPH}^{\bullet}$ (ca. $5 \times 10^{-5} \mathrm{M}$ ) was prepared and deoxygenated under nitrogen for $1.5 \mathrm{~min}$ prior to mixing with the compounds tested. The concentrations of antioxidants were at least 2 orders of magnitude greater than the concentration of $\mathrm{DPPH}^{\bullet}$.in order to obtain pseudo-first-order rate constants. The $\mathrm{DPPH}^{\bullet}$ solution was mixed 1:1 with (deoxygenated) solutions of antioxidants and the disappearance of DPPH was observed. Stopped-flow was performed using an Applied Photophysics SX 18 MV spectrometer with xenon 150 arc light source. The decay of $\mathrm{DPPH}^{\bullet}$ was monitored at $519 \mathrm{~nm}$ in the 
presence of a given (large excess) concentration of antioxidant at room temperature. Under these conditions, the decay curve was pseudo-first order, and it was well fitted by a single-exponential function $[\mathrm{DPPH}]=[\mathrm{DPPH}]_{0} \exp \left(-k_{\mathrm{obs}} t\right)+$ constant. From plots of $k_{\text {obs }}$ vs $[\mathrm{ArOH}]$ at five concentrations the second-order rate constant was obtained as the slope of the plot.

\section{Calculation of $B D E$}

Starting geometries were obtained with the PC-Spartan [43] builder module using the AM1 (Austin Model 1) method. Cartesian coordinates were then sent to the Gaussian 98 program for all subsequent calculations [44].

For calculation of the BDE, it was used the lowest level method (LLM) described by DiLabio et al. [30]. The AM1 semiempirical method was used to optimize the geometry of parent and radical $\left(\mathrm{BDE}_{1}\right)$, or radical and quinone $\left(\mathrm{BDE}_{2}\right)$, where $T=298.15$ $\mathrm{K}, P=1.00 \mathrm{~atm}$., and the AM1 frequencies were scaled by the factor 0.973 . At the geometry minimum, a single point calculation was done with (RO)B3LYP/6-311+G$(2 \mathrm{~d}, 2 \mathrm{p})$, where RO indicates that, for the radical, the restricted open-shell B3LYP method was used. All electronic energies are then corrected by the thermal contribution to the enthalpy to obtain $\mathrm{H}^{\circ}{ }_{298}$; the standard gas-phase enthalpy at $298 \mathrm{~K}$. To complete the specification of the method, I set the electronic energy of the H-atom to its exact value of -0.50000 hartree, and obtained its enthalpy $\left(\mathrm{H}^{\circ}{ }_{298}=-0.50000+5 / 2 \mathrm{RT}=-0.49764\right.$ hartree).

BDE represents the standard gas-phase enthalpy change at $298 \mathrm{~K}\left(\Delta \mathrm{H}^{0}{ }_{298}\right)$ for reaction,

$$
\operatorname{ArOH}(\mathrm{g}) \rightarrow \mathrm{ArO}^{\bullet}(\mathrm{g})+\mathrm{H}^{\bullet}(\mathrm{g})
$$




$$
\mathrm{BDE}=\sum \mathrm{H}_{298}^{\mathrm{o}}(\text { products })-\sum \mathrm{H}_{298}^{\mathrm{o}}(\text { reactants })
$$

\section{Statistics}

Data are expressed as mean $\pm \mathrm{SEM}$ values. Competitive inhibition plots are given in Result section, e.g. Figure 2.7. An exponential function gave a good fit through the data (see Figures 2.7-2.12). Using the SEM values, two additional exponentials were fitted through the top and bottom of the error bars. From these an error estimate for the $\mathrm{IC}_{50}$ was derived as follows: a line was constructed at $50 \%$ of the maximum absorbance and the minimum and maximum curves intersected this line, forming intervals. The error limit of the $\mathrm{IC}_{50}$ was taken as half of this interval. Statistical significance was assessed using a one-way ANOVA. Differences were considered significant at $p<0.05$.

\subsection{RESULTS}

Figure 2.1 shows the structures of the newly designed compounds and the well known reference antioxidants such as resveratrol (in red wine), epigallocatechin gallate (in green tea), vitamin E, trolox (solubilized form of vitamin E), and propyl gallate (in food additives). The compounds were tested for $\mathrm{H}$-atom donating ability and antioxidant capacity in cell culture. To predict the order of activity, the theoretical calculations of BDEs were run. 
<smiles>O=C(O[C@H]1Cc2c(O)cc(O)cc2O[C@H]1c1cc(O)c(O)c(O)c1)c1cc(O)c(O)c(O)c1</smiles><smiles>Oc1ccc(/C=C/c2cc(O)cc(O)c2)cc1</smiles>

Resveratrol<smiles>Cc1c(C)c2c(c(C)c1O)CCC(C)(C(=O)O)O2</smiles>

Trolox<smiles>COc1ccc(O)c(CO)c1</smiles><smiles>[2H]c1c(C)c(O)c(O)c2c1OC(C)C2</smiles><smiles>CCCCOC(=O)c1cc(O)c(O)c(O)c1</smiles>

Propyl gallate<smiles>COc1ccc(O)c(O)c1C</smiles>

$\mathrm{H}$<smiles>Oc1cc2c(cc1O)OCO2</smiles>

H3<smiles>Cc1c(C)c2c(c(C)c1O)CCC(C)(CCCC(C)C)O2</smiles>

Vitamin E<smiles>COc1c(C)c(C)c(O)c(O)c1C</smiles>

$\mathrm{H} 1$<smiles>Cc1c(O)c(O)cc2c1OCO2</smiles>

Figure 2.1. Structural formulas for the compounds tested: 2-Hydroxymethyl-4methoxy-phenol $=\mathrm{H}_{0}$, new synthetic catechols $\mathrm{H}, \mathrm{H} 1, \mathrm{H} 2, \mathrm{H} 3, \mathrm{H} 4$ and known reference antioxidants EGCG, propyl gallate, resveratrol, vitamin E, and Trolox (water-soluble vitamin $\mathrm{E})$. 


\section{BDE calculations}

Table 2.2 shows the BDEs, obtained using the lowest-level method described in Material and Methods, of compounds tested.

Table 2.2. Bond dissociation enthalpy $\left(\Delta \mathrm{H}^{\circ}{ }_{298}\right)$ for catechols and reference compounds: $\mathrm{BDE}_{1}$ is for catechol $\rightarrow$ semiquinone, $\mathrm{BDE}_{2}$ is for semiquinone $\rightarrow$ quinone.

\begin{tabular}{|c|c|c|}
\hline Compound & $\begin{array}{l}\mathrm{BDE}_{1}^{\mathrm{a}} \\
(\text { keal mol }\end{array}$ & $\begin{array}{c}\mathrm{BDE}_{2} \\
\left(\mathrm{kcal} \mathrm{mol}^{-1}\right)\end{array}$ \\
\hline$\alpha$-Tocopherol, Trolox & $77^{\mathrm{a}}$ & - \\
\hline Resveratrol & $79^{\mathrm{a}}$ & - \\
\hline Propyl gallate & $75^{\mathrm{a}}$ & $74^{\mathrm{a}}$ \\
\hline EGCG & $71^{a}$ & $74^{\mathrm{a}}$ \\
\hline $\mathbf{H}_{\mathbf{0}}$ & $79.5^{b}$ & $111^{\mathrm{b}}$ \\
\hline $\mathbf{H}^{\mathrm{a}}$ & $72.5^{b}$ & $75.8^{b}$ \\
\hline H1 & $73.6^{b}$ & $72.6^{b}$ \\
\hline H2 & $68.7^{b}$ & $71.7^{b}$ \\
\hline H3 & $69^{\mathrm{b}}$ & $67.5^{b}$ \\
\hline H4 & $66.9^{b}$ & $67.3^{b}$ \\
\hline
\end{tabular}

${ }^{a}$ Literature values from ref. [14].

${ }^{\mathrm{b}}$ Literature values from ref [31].

\section{DPPH* kinetics results}

To determine the H-atom donating ability of the designed catechols and vitamin E, I measured their reactivity toward the $\mathrm{DPPH}^{\bullet}$ radical in ethyl acetate. The secondorder rate constants, $k_{\mathrm{DPPH}}$. were obtained by following the decay of $\mathrm{DPPH}^{\bullet}$ at $519 \mathrm{~nm}$ in 
the presence of excess antioxidant at various concentrations using a stopped-flow spectrophotometer at room temperature.

Detailed experimental results are showed in Table 2.3 and Figure 2.2, using one of the catechols (H3) as an example. Table 2.3 shows the first order rate constants, $\mathrm{k}_{\exp }$, for seven concentrations of $\mathrm{H} 3$. The $\mathrm{k}_{\mathrm{exp}}$ increases as the concentration of $\mathrm{H} 3$ rises. The results were plotted and Figure 2.2 shows the concentration of H3 vs. $\mathrm{k}_{\exp }$. A very good linear correlation was obtained with the $\mathrm{R}^{2}$ value being 0.994 . The slope, which gives the second order rate constant, had a value of $5037 \mathrm{M}^{-1} \mathrm{~s}^{-1}$. 
Table 2.3. Data obtained from stopped-flow analysis of different concentrations of $\mathrm{H} 3$ reacting with $\mathrm{DPPH}^{\bullet}$ in ethyl acetate: time of reaction, rate constants of each run $(n=4)$ and the average of $k_{\text {exp }}$.

\begin{tabular}{|c|c|c|c|c|c|c|}
\hline Concentration of H3 & $\begin{array}{l}\text { Time of } \\
(\mathrm{M})\end{array}$ & $\begin{array}{l}\mathrm{k}_{\exp } \text { run 1 } \\
\left(\mathrm{s}^{-1}\right)\end{array}$ & $\begin{array}{l}\mathrm{k}_{\exp } \text { run 2 } \\
\left(\mathrm{s}^{-1}\right)\end{array}$ & $\begin{array}{l}\mathrm{k}_{\exp } \text { run 3 } \\
\left(\mathrm{s}^{-1}\right)\end{array}$ & $\begin{array}{l}\mathrm{k}_{\exp } \text { run } 4 \\
\left(\mathrm{~s}^{-1}\right)\end{array}$ & $\begin{array}{l}\mathrm{k}_{\exp } \text { average } \\
\left(\mathrm{s}^{-1}\right)\end{array}$ \\
\hline $2.49 \times 10^{-4}$ & 5 & 1.238 & 1.222 & 1.246 & 1.235 & 1.23533 \\
\hline $3.74 \times 10^{-4}$ & 5 & 1.847 & 1.863 & 1.899 & 1.88 & 1.87225 \\
\hline $5.6 \times 10^{-4}$ & 2 & 2.623 & 2.67 & 2.72 & 2.627 & 2.66 \\
\hline $8.4 \times 10^{-4}$ & 1 & 4.338 & 4.318 & 4.289 & 4.335 & 4.32 \\
\hline $1.26 \times 10^{-3}$ & 1 & 6.143 & 6.144 & 6.137 & 6.11 & 6.1335 \\
\hline $1.89 \times 10^{-3}$ & 1 & 9.085 & 9.263 & 9.222 & 9.545 & 9.27875 \\
\hline $2.44 \times 10^{-3}$ & 0.5 & 12.26 & 12.282 & 12.522 & 12.424 & 12.372 \\
\hline
\end{tabular}




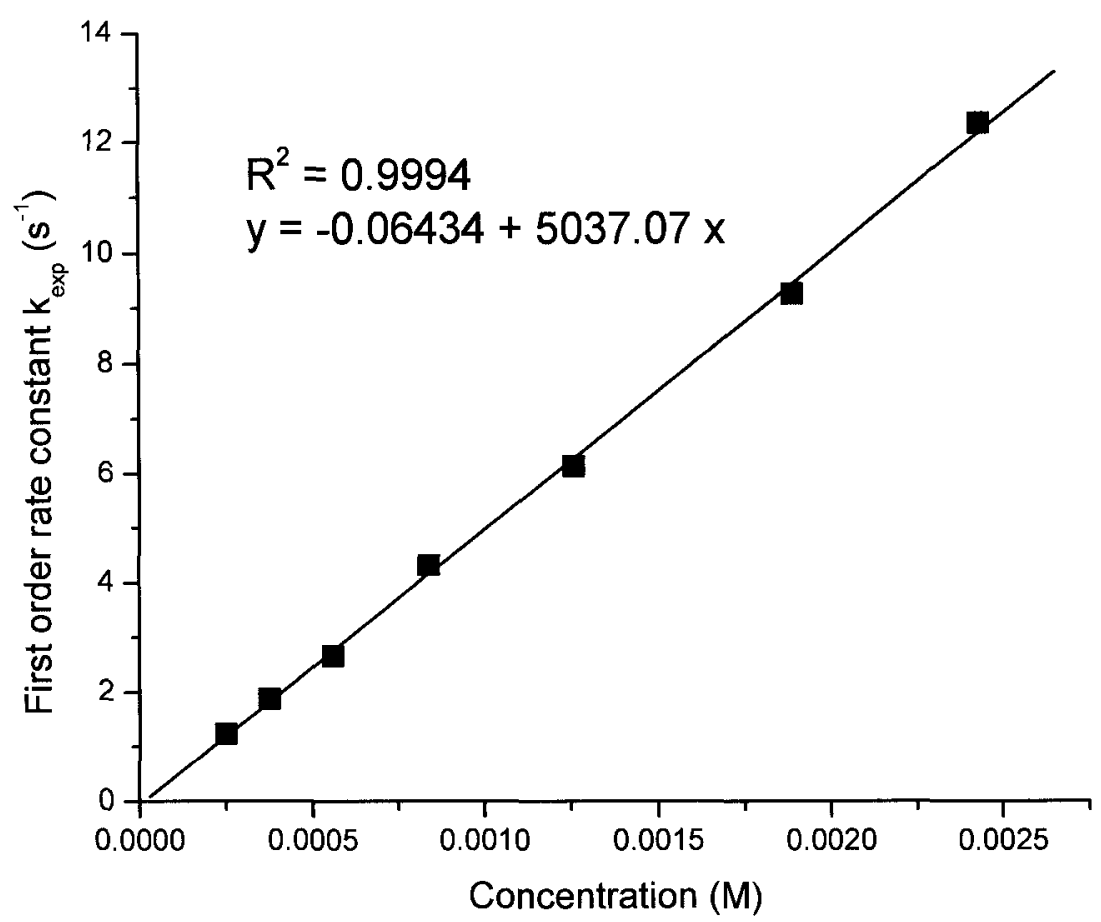

Figure 2.2. Plot of the first order rate constant $\mathrm{k}_{\mathrm{exp}}$ vs. concentration of $\mathrm{H} 3$. The slope of this graph represents the second order rate constant $\mathrm{k}_{\mathrm{DPPH}}$.

Table 2.4 shows all the results of the kinetic studies on synthetic catechols and $\alpha$ tocopherol. Reproducibility in the kinetic runs was excellent with very little deviation in the linear fit of the data, as shown by the high $\mathrm{R}^{2}$ value. Values of the second order rate constant $k_{\mathrm{DPPH}}$ range from 2.9 to 8870 , with $\mathrm{H} 3$ and $\mathrm{H} 4$ being the most reactive (almost 2 orders of magnitude more reactive with $\mathrm{DPPH}^{\bullet}$ in ethyl acetate than $\alpha$-tocopherol). The calculated BDE values are given in Table 2.4. 
Table 2.4. Rate constants for $\mathrm{DPPH}^{\bullet}+$ compounds in ethyl acetate solvent, $\mathrm{R}^{2}$ values, calculated $\mathrm{BDE}_{1}$.

\begin{tabular}{|c|c|c|c|}
\hline Compound & $\begin{array}{c}k\left(\mathrm{M}^{-1} \mathrm{~s}^{-1}\right) \\
(\mathrm{EtOAc})\end{array}$ & $\mathrm{R}^{2}$ & $\begin{array}{c}\mathrm{BDE}_{1}^{\mathrm{a}} \text { calc. } \\
\left(\mathrm{kcal} \mathrm{mol}^{-1}\right)\end{array}$ \\
\hline$\alpha$-tocopherol & $160^{\mathrm{b}}$ & $0.9992^{\mathrm{b}}$ & $75.0^{\mathrm{c}}$ \\
\hline $\mathrm{H}_{0}$ & $2.9^{\mathrm{d}}$ & $0.9942^{\mathrm{d}}$ & $79.5^{\mathrm{d}}$ \\
\hline $\mathrm{H}$ & $200^{\mathrm{d}}$ & $0.9995^{\mathrm{d}}$ & $72.5^{\mathrm{d}}$ \\
\hline $\mathrm{H} 1$ & 210 & 0.9993 & 73.6 \\
\hline $\mathrm{H} 2$ & 3000 & 0.9999 & 68.7 \\
\hline $\mathrm{H} 3$ & 5037 & 0.9994 & $69.0^{\mathrm{d}}$ \\
\hline $\mathrm{H} 4$ & 8870 & 0.9984 & $66.9^{\mathrm{d}}$ \\
\hline
\end{tabular}

${ }^{a} \mathrm{BDE}_{1}$ for loss of the second $\mathrm{H}$ atom after the first has already been lost.

${ }^{b}$ Literature value from ref [45].

${ }^{c}$ The $\mathrm{C}_{16} \mathrm{H}_{33}$ (phytyl tail) was replaced by a methyl group in the calculation.

${ }^{\mathrm{d}}$ Literature values from ref [31].

Figure 2.3 shows a very good linear correlation between rate constants and calculated BDEs, with a $\mathrm{R}^{2}$ value of 0.976 for seven points. A lower BDE means a higher rate of scavenging the DPPH radicals. 


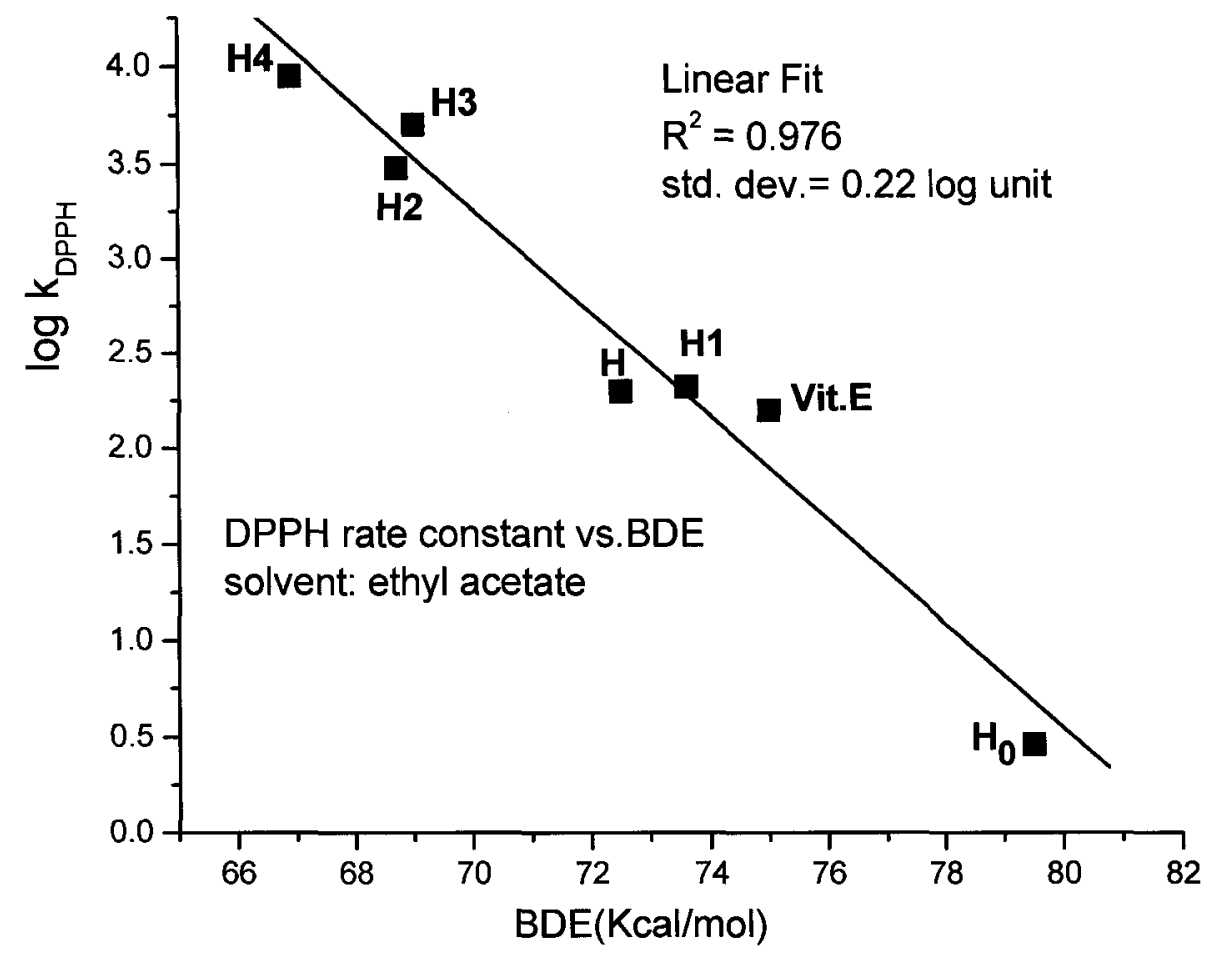

Figure 2.3. Plot of $\log \mathrm{k}_{\mathrm{DPPH}}$ vs. calculated BDEs of $\mathrm{H}_{0}, \mathrm{H}, \mathrm{H} 1, \mathrm{H} 2, \mathrm{H} 3, \mathrm{H} 4$, and Vitamin E.

Cytochrome C assay with HL-60 cells:

In order to test the ability of antioxidants to quench the ROS produced inside the cells, tests were run on HL-60 cells using the cytochrome $\mathrm{C}$ assay. Cells were differentiated and then stimulated with PMA to generate superoxide radicals. The cytochrome $\mathrm{C}$ assay is based on the change in absorbance at $550 \mathrm{~nm}$ as a result of the change in valence of the heme iron according to the reaction:

Cytochrome $\mathrm{C}(\mathrm{III})+\mathrm{O}_{2}^{\bullet-}$ (superoxide anion) $\rightarrow$ Cytochrome $\mathrm{C}(\mathrm{II})+\mathrm{O}_{2}$

Orange $\uparrow$ colour $\quad$ purple $\uparrow$ colour 
I first characterized the cells by checking the viability in culture and also the rate of growth over 5 days. I defined cell viability as the ratio of the number of viable cells relative to the total number of cells. The total number and viability of cells were determined by the trypan blue dye exclusion method.

Figure 2.4 shows the concentration of HL-60 cells in culture over the 5 days. I started with approximately 125,000 cells $/ \mathrm{mL}$ on day one. Cells were doubling exponentially in the linear portion of the log plot. This is between $\sim 125,000-700,000$ cells $/ \mathrm{mL}$, after which they get crowded and their growth slows. At high concentrations of cells, cell growth declines due to the buildup of metabolites (e.g. lactic acid) in the media that inhibit proper growth. Thus, the cell concentration in culture should be kept below 750,000 cells $/ \mathrm{mL}$ for a good viability.

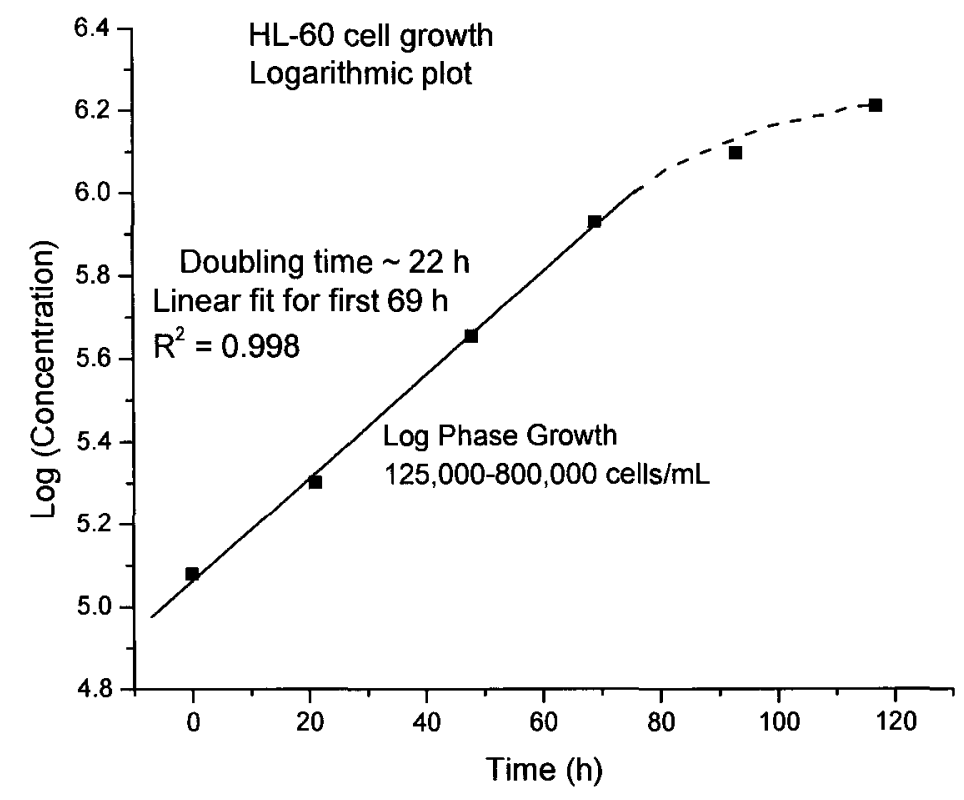

Figure 2.4. $\log$ (concentration) vs time (h). The total number of viable and nonviable cells was determined using the trypan blue method. Dead cells were blue due to the accumulation of the dye in cells. 
The conditions of the experiment (such as DMSO treatment, starting concentration of cell, concentration of cytochrome $\mathrm{c}$ and so on) were optimized in order to get reproducible results.

The next steps were to induce the differentiation of cells using 1.3\% DMSO and determine the optimal time of treatment with the differentiation agent. Cell viability had to be higher than $95 \%$ in order to use them in experiments. Cells at a concentration of $\sim 200,000$ cells $/ \mathrm{mL}$ were incubated in growth medium containing $1.3 \%$ DMSO. Cell viability and the total number of cells were checked every $20-24 \mathrm{~h}$ over 7 days using the trypan blue assay. HL-60 cells increase their ability to produce superoxide ions after differentiation [44]. In order to test the capacity of the differentiated cells to produce superoxide, the cytochrome $\mathrm{C}$ assay was run (data not shown after four, five, six and seven days of differentiation, respectively. I have observed that the cell viability starts to decline after 6 days of differentiation (DMSO is toxic for cells) and the rate of superoxide production reaches a maximum after six days of differentiation.

Figure 2.5 shows the results of growth rate of the cells treated with DMSO compared to controls (no treatment). For the first $24 \mathrm{~h}$, the cell number doubled and after that the cells growth slowed. After six days the cells were no longer dividing. 


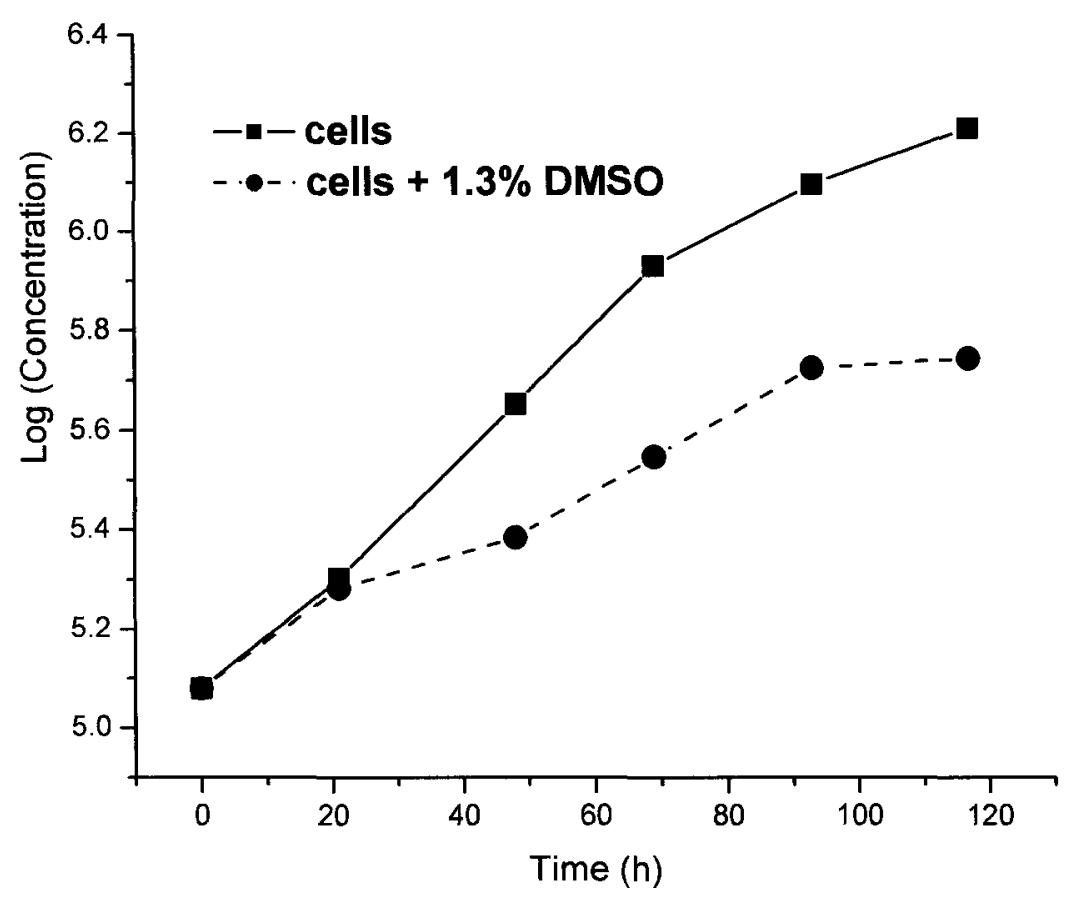

Figure 2.5. Plot of $\log$ (concentration) vs time (h). HL-60 at a density of 200,000 cells $/ \mathrm{mL}$ were grown in the presence or absence $1.3 \%$ DMSO. The concentration of cells was determined using the trypan blue method.

After five days in DMSO, cells were collected by centrifugation, washed twice with HBSS and resuspended in HBSS. Resuspended cells were added to a microplate at 5 different densities. The indicator used in experiments was $80 \mu \mathrm{M}$ cytochrome $\mathrm{C}$, in the iron (III) state (final concentration in well). Cells were stimulated to produce superoxide with PMA (1 $\mu \mathrm{M})$. Superoxide converts cytochrome C (III) to cytochrome C (II) [36]. Controls contained $137 \mu \mathrm{L}$ cells, $75 \mu \mathrm{L}$ cytochrome $\mathrm{C}, 4 \mu \mathrm{L}$ PMA and $4 \mu \mathrm{L}$ HBSS per well. Figure 2.6 shows the result of this experiment. When all of the $80 \mu \mathrm{M}$ of 
cytochrome $\mathrm{C}$ is converted, the absorbance reaches a maximum and then slowly declines due to a back reaction of ferrocytochrome $\mathrm{C}$ with $\mathrm{O}_{2}[36]$.

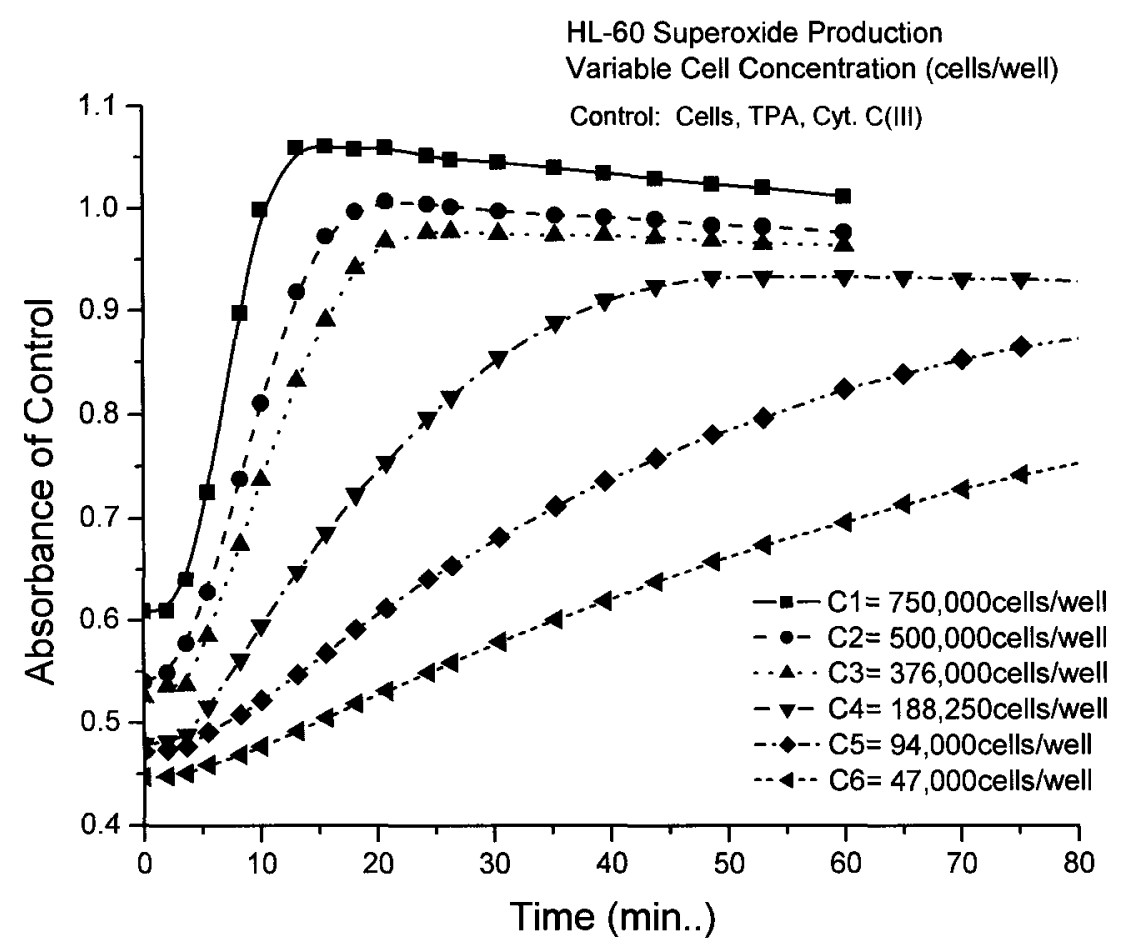

Figure 2.6. Change in cytochrome $\mathrm{C}$ absorbance over time for different cell concentrations. The absorbance of a solution containing differentiated cells, $80 \mu \mathrm{M}$ cytochrome $\mathrm{c}$ and $1 \mu \mathrm{M}$ PMA is recorded at $550 \mathrm{~nm}$ in a SpectroMax $340^{\mathrm{PC}}$ microplate reader at $37^{\circ} \mathrm{C}$.

The first two columns of Table 2.5 show five different concentrations of cells used in experiments and the time necessary for them to completely consume $80 \mu \mathrm{M}$ cytochrome C. Column 3 shows the rate of superoxide production by the cells in each well. From Column 4 of Table 2.5 it is clear that the calculated nmols of superoxide produced per min by $10^{6}$ cells is approximately the same in all wells: $\left(\sim 3.00 \mathrm{nmols} \mathrm{O}_{2}{ }^{--} / \mathrm{min}\right)$. 
Table 2.5. Rates of $\mathrm{O}_{2}^{--}$production by five different concentrations of cells and calculated nmols of $\mathrm{O}_{2}{ }^{\bullet-}$ produced per min by $10^{6}$ cells.

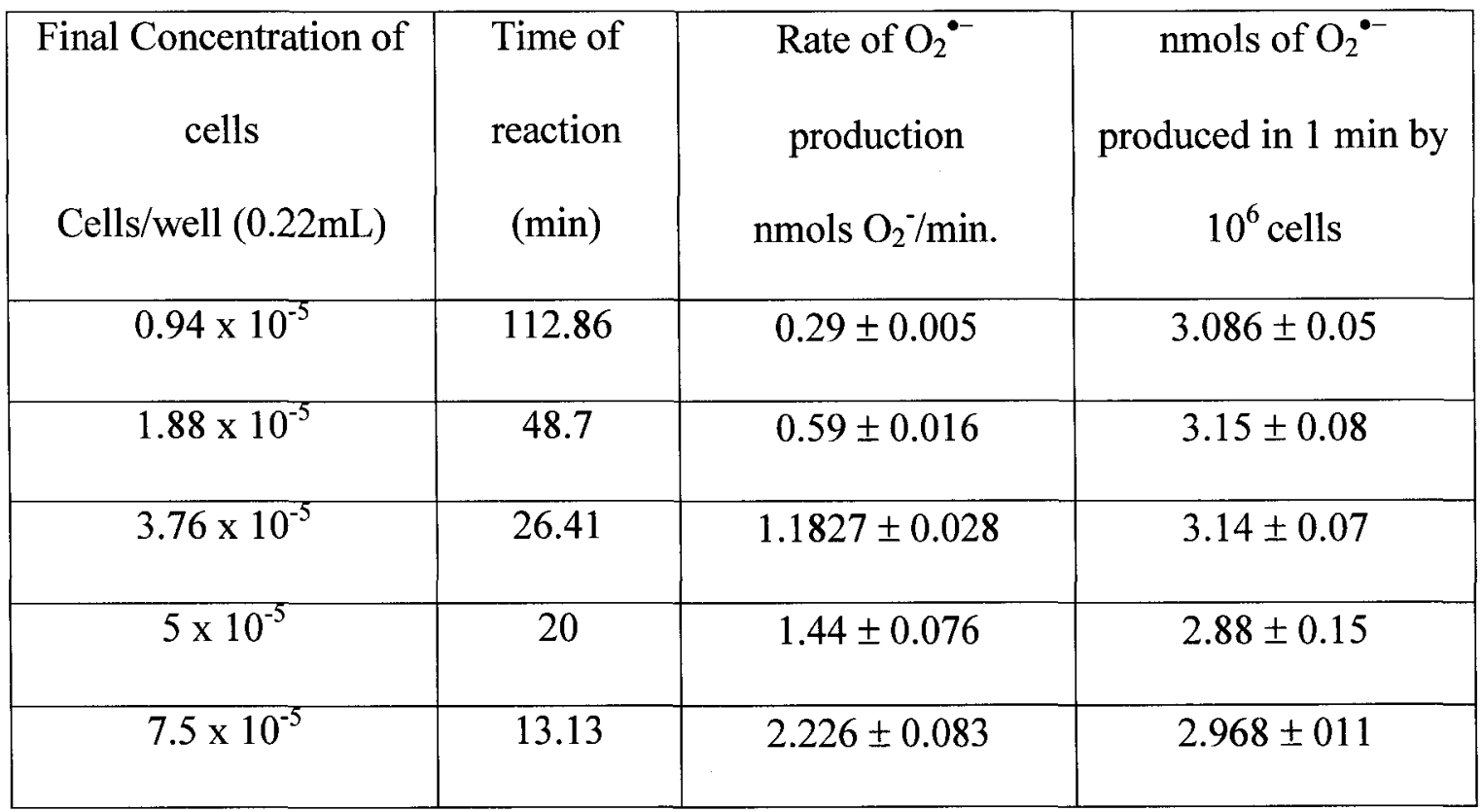

I concluded that the following optimal parameters were necessary for subsequent experiments in order to determine, with reproducible results, the antioxidant activity of the compounds tested:

- The time of incubation with DMSO $~ 5$ days

- The viability of the cells $>95 \%$

- The concentration of cytochrome $\mathrm{C} \sim 80 \mu \mathrm{M}$ (gives an absorbance of $\sim 0.4 \mathrm{OD}$ )

- The density of cells $\sim 220,000$ cells/well (each well contains $0.22 \mathrm{~mL}$, so this is a cells concentration of about $1 \times 10^{6}$ cells $/ \mathrm{mL}$ ).

Antioxidants (ArOH) were added to the solution of differentiated cells stimulated with PMA to generate superoxide. According to reaction (5) with no antioxidant present, orange cytochrome $\mathrm{C}(\mathrm{III})$ is converted to purple cytochrome $\mathrm{C}(\mathrm{II})$, while with antioxidant 
present, the production of the purple product is suppressed. Thus, the following mixtures (6 replicates for each) were prepared:

Test: $137 \mu \mathrm{L}$ Cells, $75 \mu \mathrm{L}$ cytochrome C(III), $4 \mu \mathrm{L}$ PMA, $4 \mu \mathrm{L}$ Compound tested Standard: $137 \mu \mathrm{L}$ Cells, $75 \mu \mathrm{L}$ cytochrome C(III), $4 \mu \mathrm{L}$ EtOH, $4 \mu \mathrm{L}$ Compound tested Control: $137 \mu \mathrm{L}$ Cells, $75 \mu \mathrm{L}$ cytochrome C(III), $4 \mu \mathrm{L}$ PMA, $4 \mu \mathrm{L}$ HBSS Blank: $137 \mu \mathrm{L}$ Cells, $75 \mu \mathrm{L}$ cytochrome C(III), $4 \mu \mathrm{L}$ EtOH, $4 \mu \mathrm{L}$ HBSS

The mixtures were incubated for 40 minutes at $37{ }^{\circ} \mathrm{C}$, in a humidified atmosphere $(5 \%$ $\mathrm{CO}_{2}$ in air). Treatments were read on a microplate reader at $550 \mathrm{~nm}$.

Figures 2.7 to 2.14 show the results of these experiments. From these plots, I get the $\mathrm{IC}_{50}$, (i.e. the concentration of antioxidant needed to suppress $50 \%$ of the formation of the cytochrome C (II) which represents $50 \%$ of the production of free radicals). The lower the $\mathrm{IC}_{50}$, the more potent the antioxidant.

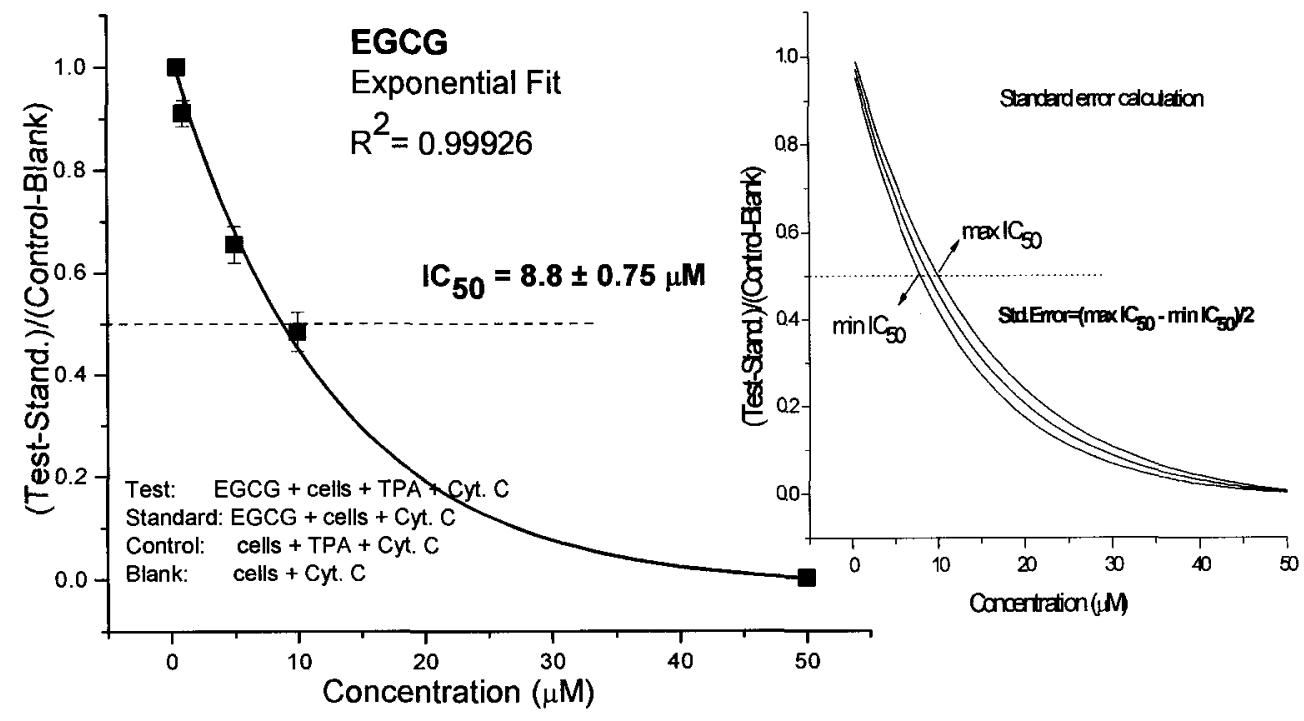

Figure 2.7. Absorbance vs. concentration of EGCG. Differentiated cells, stimulated with PMA, were incubated with $0.5,1.5,10,50 \mu \mathrm{M}$ EGCG and cytochrome C. 


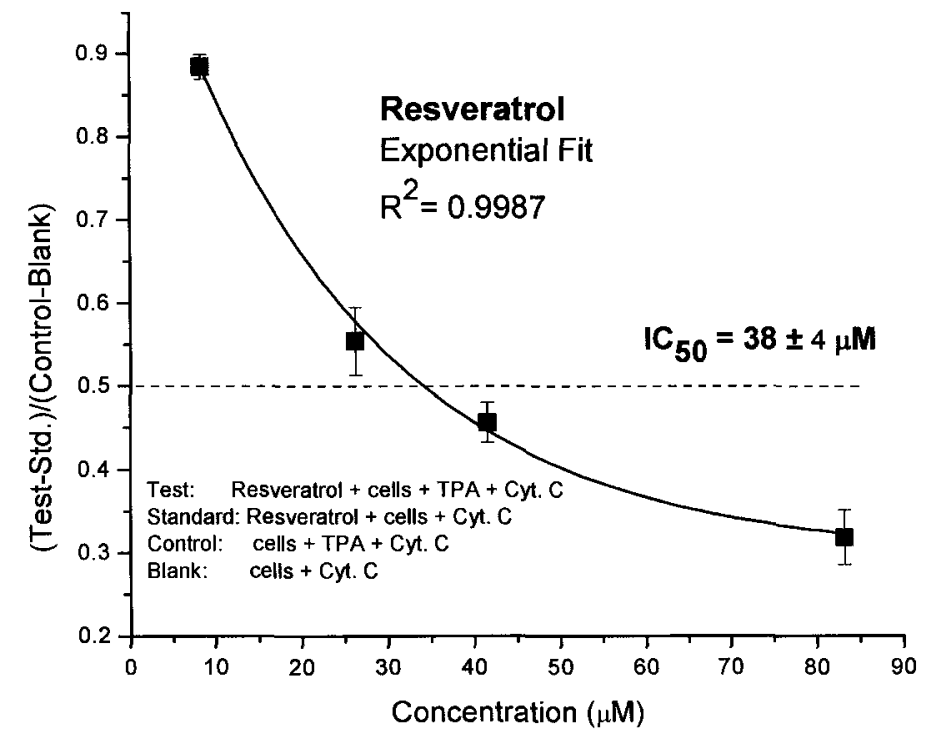

Figure 2.8. Absorbance vs. concentration of resveratrol. Differentiated cells, stimulated with PMA, were incubated with 8.3, 26.2, 41.6, 83.2 $\mu \mathrm{M}$ resveratrol and cytochrome C.

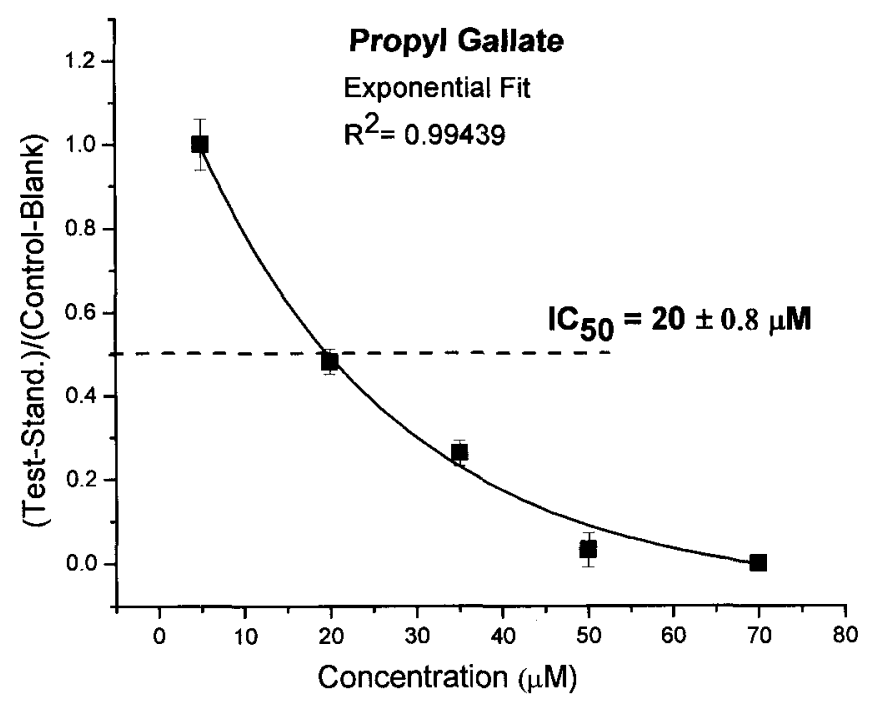

Figure 2.9. Absorbance vs. concentration of propyl gallate. Differentiated cells, stimulated with PMA, were incubated with $5,20,35,50,70 \mu \mathrm{M}$ propyl gallate and cytochrome $\mathrm{C}$. 


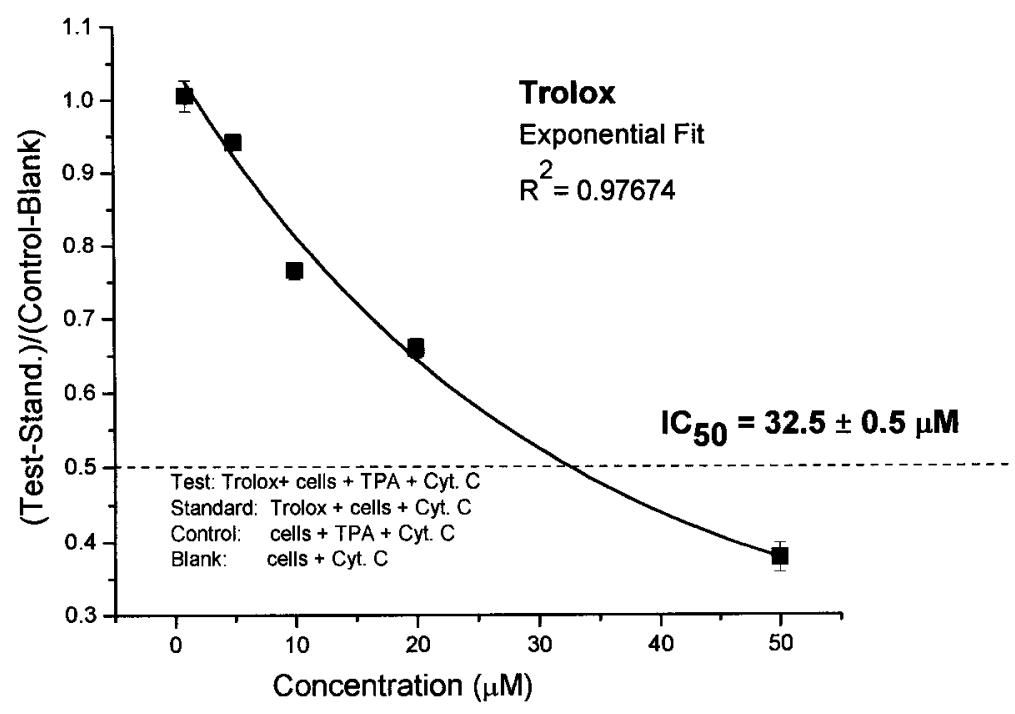

Figure 2.10. Absorbance vs. concentration of Trolox (water-soluble Vit. E). Differentiated cells, stimulated with PMA, were incubated with $1,5,10,20,50 \mu \mathrm{M}$ EGCG and cytochrome C.

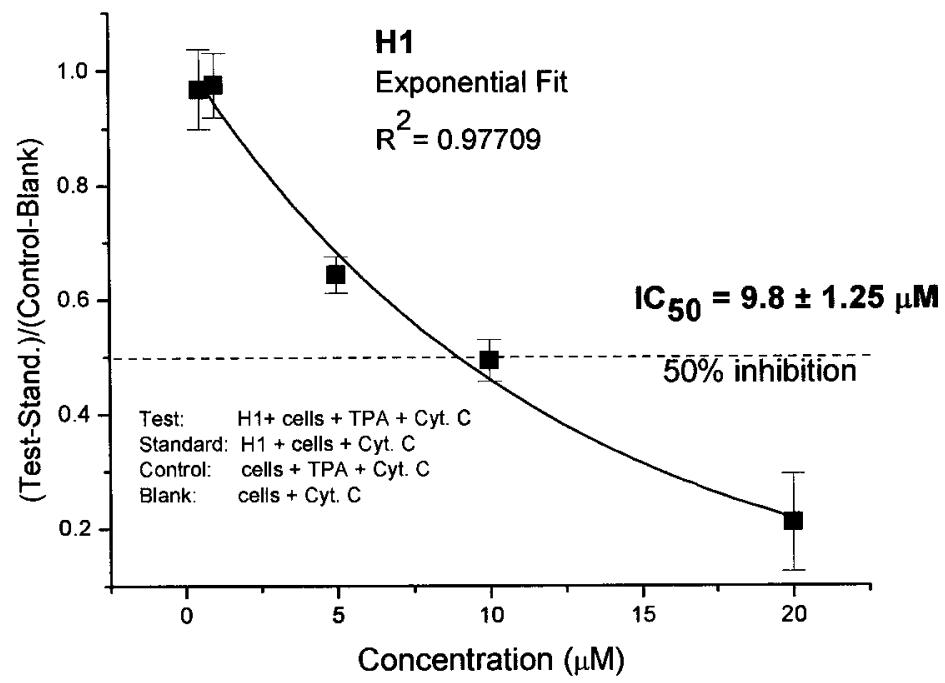

Figure 2.11. Absorbance vs. concentration of H1. Differentiated cells, stimulated with PMA, were incubated with $0.5,1,5,10,20 \mu \mathrm{M} \mathrm{H} 1$ and cytochrome $\mathrm{C}$. 


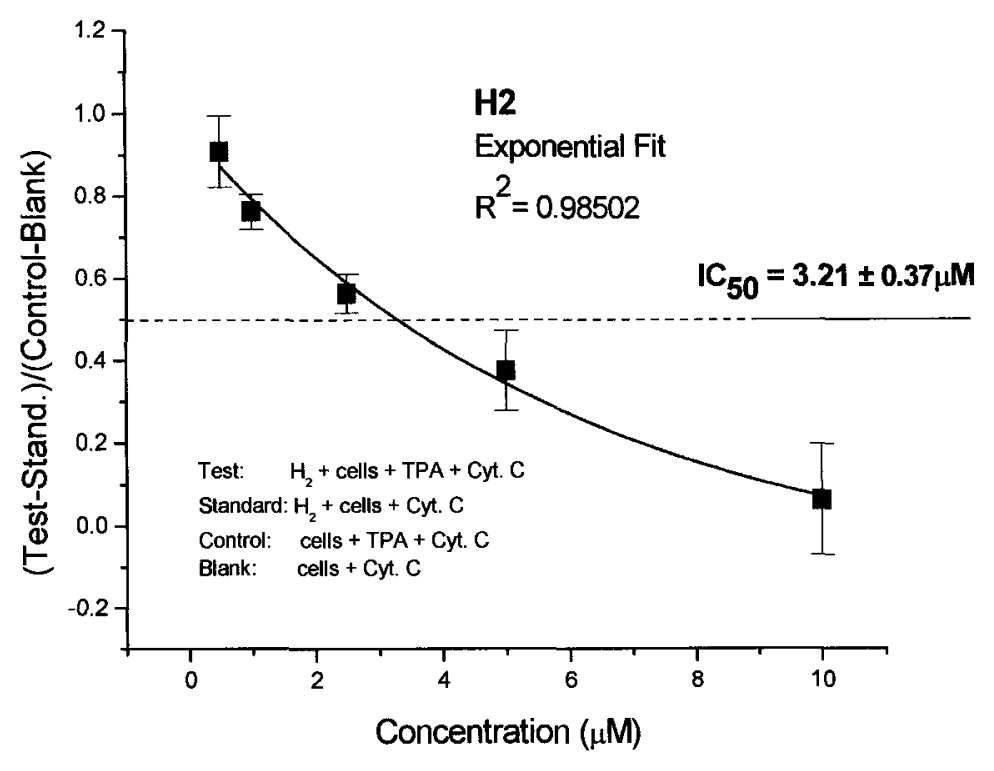

Figure 2.12. Absorbance vs. concentration of $\mathrm{H} 2$. Differentiated cells, stimulated with PMA, were incubated with $0.5,1,2.5,5,10 \mu \mathrm{M} \mathrm{H} 2$ and cytochrome C.

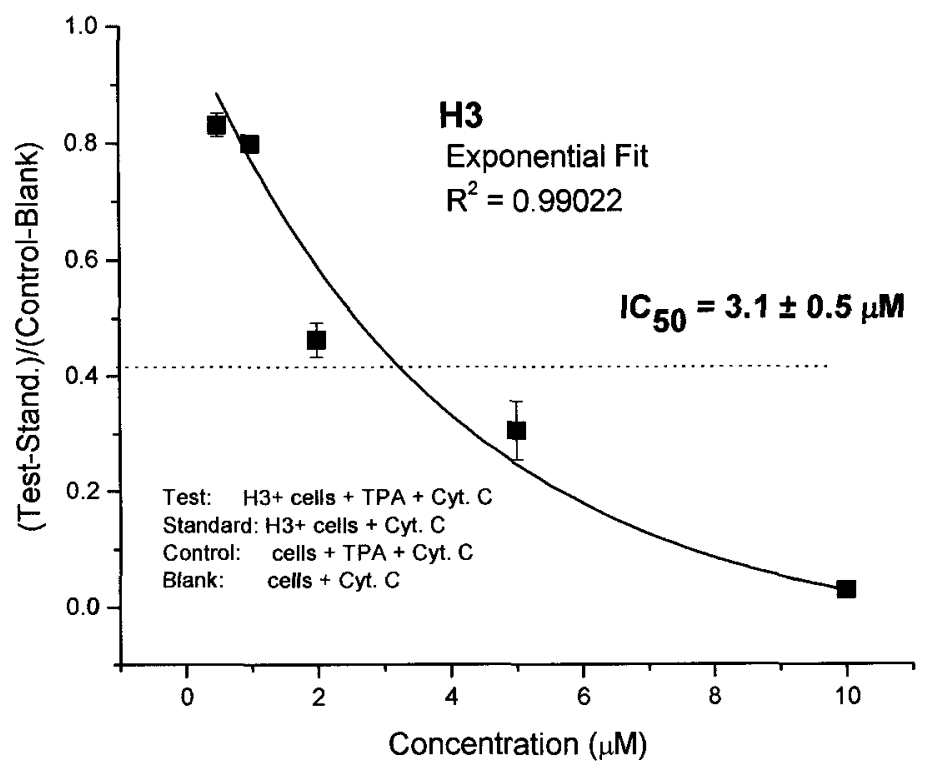

Figure 2.13. Absorbance vs. concentration of $\mathrm{H} 3$. Differentiated cells, stimulated with PMA, were incubated with $0.5,1,2,5,10 \mu \mathrm{M} \mathrm{H} 3$ and cytochrome $\mathrm{C}$. 


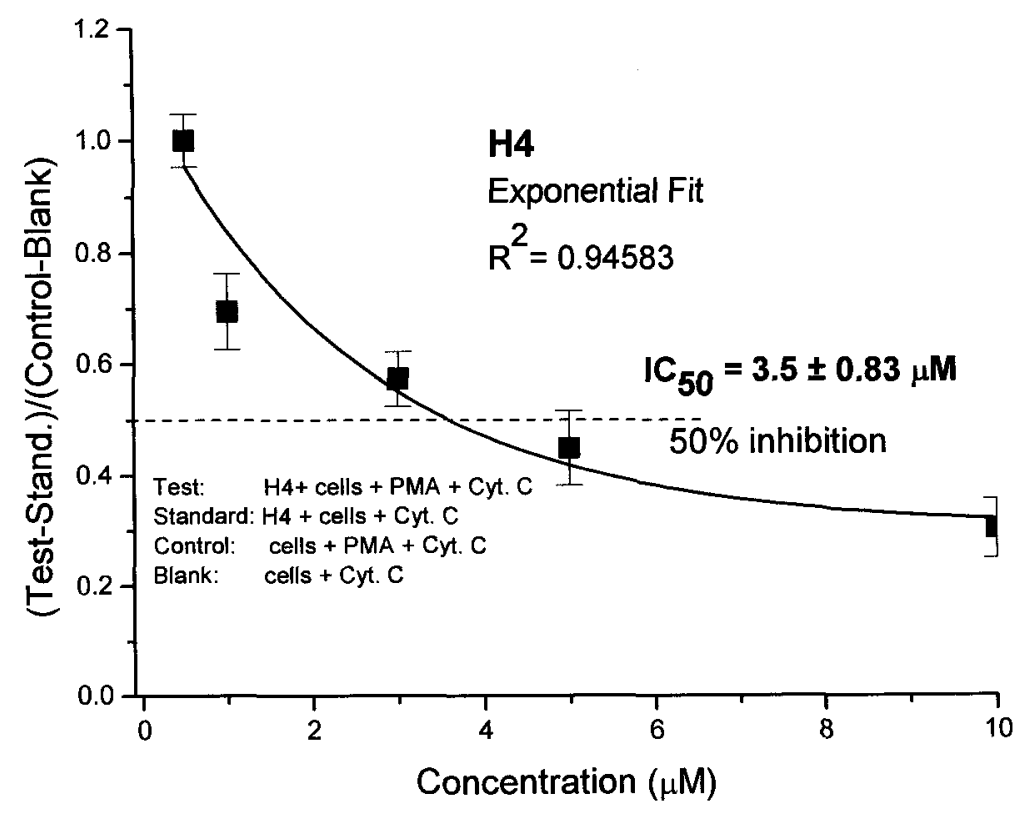

Figure 2.14. Absorbance vs. concentration of H4. Differentiated cells, stimulated with PMA, were incubated with $0.5,1,2,5,10 \mu \mathrm{M} \mathrm{H} 4$ and cytochrome C.

Figure 2.15 shows a very good linear correlation between $\mathrm{IC}_{50}$ and calculated BDEs, with a $\mathrm{R}^{2}$ of 0.9533 for 8 points. A lower $\mathrm{BDE}$ means a lower $\mathrm{IC}_{50}$ and therefore a higher rate of scavenging of free radicals. 


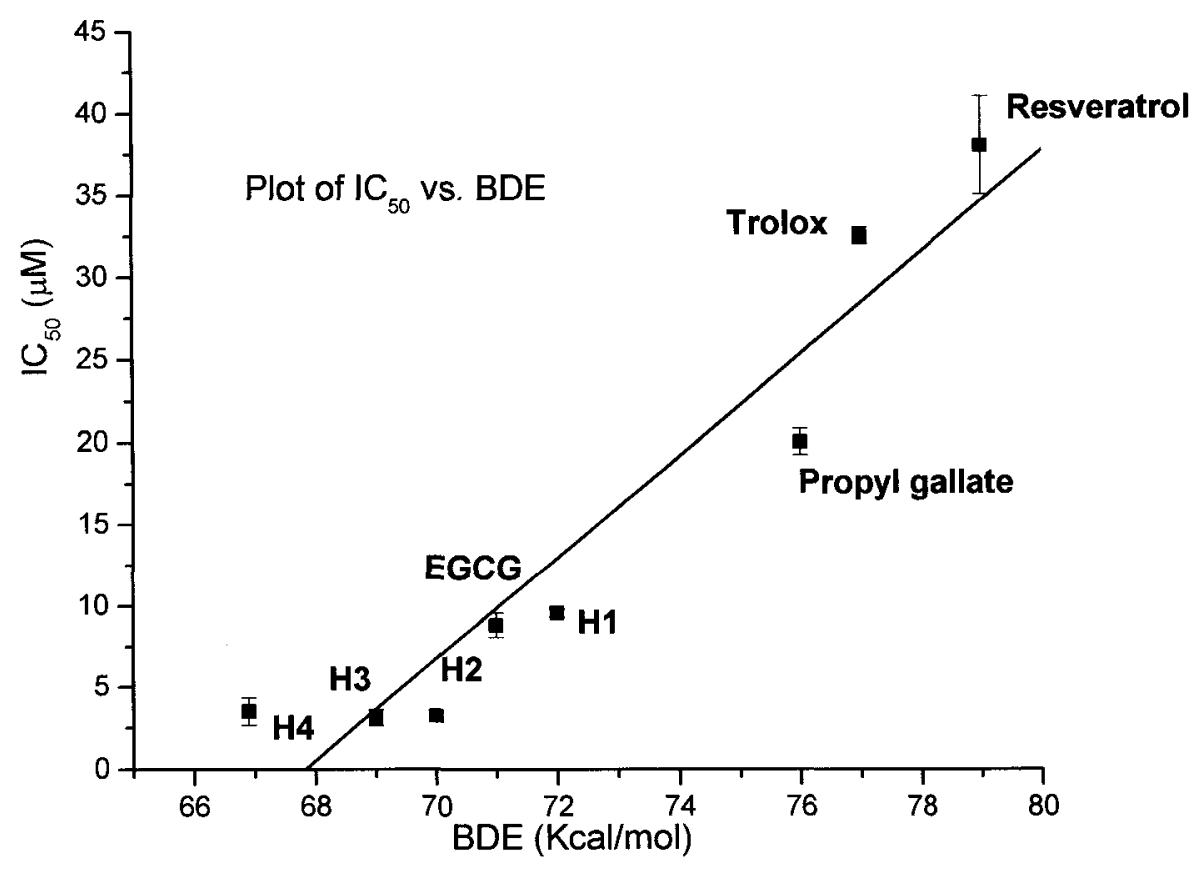

Figure 2.15. Plot of $\mathrm{IC}_{50}$ vs. BDE for synthetic compounds $\mathrm{H} 1, \mathrm{H} 2, \mathrm{H} 3, \mathrm{H} 4$ and known antioxidant EGCG, propyl gallate, resveratrol, and Trolox.

\subsection{DISCUSSION}

\section{Design strategy: BDE calculations}

In this chapter, we designed and tested molecules with the structure of the catechol, i.e. 1,2-dihydroxybenzene $\left(\mathrm{H}_{0}, \mathrm{H}, \mathrm{H} 1, \mathrm{H} 2, \mathrm{H} 3, \mathrm{H} 4\right)$ as well as known reference antioxidants such as EGCG, resveratrol, propyl gallate and Trolox for free radical scavenging ability. Discussions of the parameters which are important in designing molecules with superior antioxidant activity were presented in the Introduction of this chapter.

Thus, the answer to the question "Why were catechols used as the first generation of new antioxidants designed?" is evident. By adding an $\mathrm{OH}$ group to the ortho-position 
of the phenol, the BDE drops from $87.1 \mathrm{kcal} \mathrm{mol}^{-1}$ (phenol) to $77.9 \mathrm{kcal} \mathrm{mol}^{-1}$ (based on additivity rules as $-9.2 \mathrm{kcal} \mathrm{mol}^{-1}$ ) and thus, the BDE of catechol itself is almost in the design window. By adding other electron-donating functional groups such as methyl, hydroxyl and methoxy to catechols a variety of molecules with a BDE $<77 \mathrm{kcal} \mathrm{mol}^{-1}$ (vitamin E) will be created.

We calculated a BDE for phenol of $87.10 \mathrm{kcal} \mathrm{mol}^{-1}$, in good agreement with a current experimental gas-phase value of $87.3 \mathrm{kcal} \mathrm{mol}^{-1}$ obtained by Wayner et al. [46]. Catechols $\left(\mathrm{QH}_{2}\right)$ donate their first hydrogen to a radical (represented by BDE $)$ such as $\mathrm{ROO}^{\bullet}$, forming the semiquinone $\mathrm{QH}^{\bullet}$ and $\mathrm{ROOH}$, according to:

$$
\mathrm{QH}_{2}+\mathrm{ROO}^{\bullet} \rightarrow \mathrm{QH}^{\bullet}+\mathrm{ROOH}
$$

and breaking the chain reaction of lipid peroxidation. The cellular reducing equivalents, such as ascorbate and glutathione, reduce the semiquinone back to the catechol form. Thus, the effectiveness of $\mathrm{QH}_{2}$ as an antioxidant is strongly correlated with $\mathrm{BDE}_{1}$. The semiquinone can lose the second hydrogen $\left(\mathrm{BDE}_{2}\right)$ forming the corresponding quinone according to:

$$
\mathrm{QH}^{\bullet}+\mathrm{O}_{2} \rightarrow \mathrm{Q}+\mathrm{HO}_{2}^{\bullet}
$$

Since the $\mathrm{pK}_{\mathrm{a}}$ of the semiquinone tends to be low [47], its conjugate base $\mathrm{Q}^{\bullet-}$ donates an electron to oxygen to form superoxide and the quinone $Q$

$$
\mathrm{Q}^{\bullet-}+\mathrm{O}_{2} \rightarrow \mathrm{Q}+\mathrm{O}_{2}^{\bullet-}
$$

The first compound tested was $\mathrm{H}_{0}$ (2-hydroxymethyl-4-methoxyphenol), in which the weaker bond is the phenolic $\mathrm{OH}$ and the stronger bond is the benzylic $\mathrm{OH}$. Scheme 2.3 shows the formation of phenoxyl radical by abstraction of the first $\mathrm{H}$ and then by abstraction of second $\mathrm{H}$, resulting in a triplet diradical formed. We predicted a $\mathrm{BDE}_{1}$ of 
$79 \mathrm{kcal} \mathrm{mol}^{-1}$ based on additivity rules $\left[87 \mathrm{kcal} \mathrm{mol}^{-1}\right.$ (phenol BDE) $-6 \mathrm{kcal} \mathrm{mol}^{-1}(p$ methoxy) - $2 \mathrm{kcal} \mathrm{mol}^{-1}$ (o-methyl)]. The calculated $\mathrm{BDE}_{1}$ was $79.5 \mathrm{kcal} \mathrm{mol}^{-1}$. A BDE for the second exchangeable $\mathrm{OH}$ was calculated to be $111 \mathrm{kcal} \mathrm{mol}^{-1}$ and therefore would not participate in any exchange reaction.

\section{SCHEME 2.3}

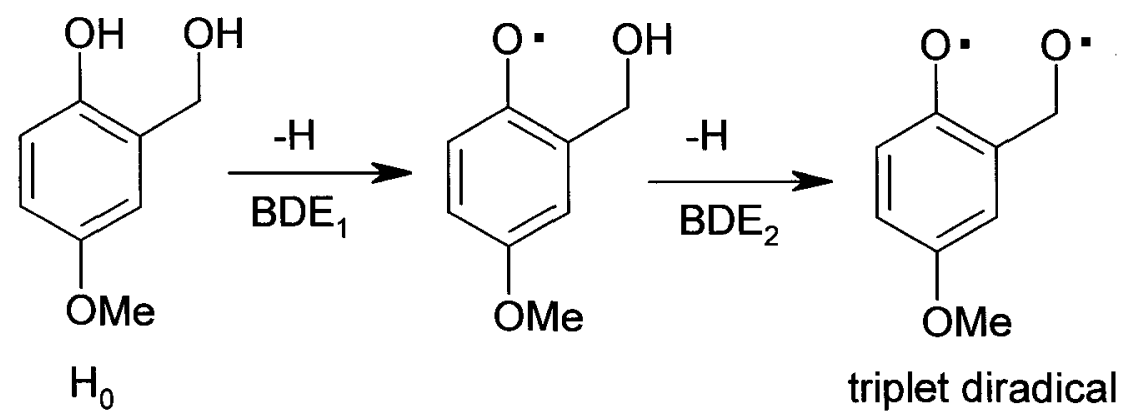

The next antioxidant tested was the catechol $\mathrm{H}$ (3-methyl-4-methoxy-1,2dihydroxybenzene) with a predicted $\mathrm{BDE}_{1}$ of $71.5 \mathrm{kcal} \mathrm{mol}^{-1}$ [87 (phenol $\left.\mathrm{BDE}_{1}\right)-9$ (ortho-hydroxy)- $0.5 \mathrm{kcal}$ (meta-methyl group) $-6 \mathrm{kcal}$ (para-methoxy)] $=71.5 \mathrm{kcal} \mathrm{mol}^{-}$ ${ }^{1}$ ] which is in agreement with observed $\mathrm{BDE}_{1}$ of $72.5 \mathrm{kcal} \mathrm{mol}^{-1}$. Its $\mathrm{BDE}_{2}$ of $75.8 \mathrm{kcal}$ $\mathrm{mol}^{-1}$ is comparable to the BDE of $\alpha$-tocopherol.

Catechol H1 (4-methoxy-3,5,6-trimethylbenzene-1,2-diol) has a fully substituted benzene ring. Based on additivity values, it was predicted that the $\mathrm{BDE}_{1}$ is $71 \mathrm{kcal} \mathrm{mol}^{-1}$ [-9 (catechol), -2 (ortho-methyl), -1.0 (two meta-methyl), and -6.0 (para-methoxy)]. We calculated a BDE of $73.6 \mathrm{kcal} \mathrm{mol}^{-1}$. The geometry of catechol H1 (Figure 2.16) could explain this difference. 


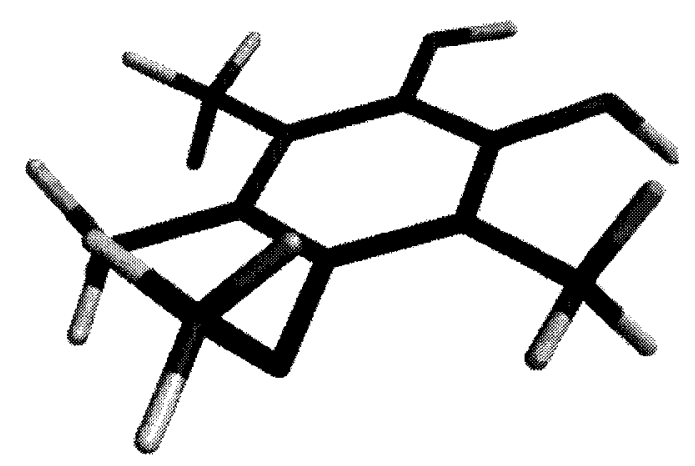

Figure 2.16. Structure of fully substituted catechol H1.

The methoxy group is rotated $90^{\circ}$ out of the plane because of the interaction with the adjacent methyl groups. This reduces optimal overlap of the methoxy oxygen relative to its normal position, rendering this a substituent that is less likely to donate electrons; the corrected additivity value for this substituent is only $-2.6 \mathrm{kcal} \mathrm{mol}^{-1}$, leading to a much better estimate of the effect of this functional group on the BDE. Loss of the second $\mathrm{H}$ atom is even faster with a $\mathrm{BDE}_{2}$ of $72.6 \mathrm{kcal} \mathrm{mol}^{-1}$.

Compound $\mathrm{H} 2$ is the bicyclic catechol 2,3-dihydro-2,6,7-trimethyl-4,5dihydroxybenzofuran, whose structure bears a resemblance to $\alpha$-tocopherol. This molecule also has a five-membered ring which enhances its planarity $[48,49]$. The phytyl tail was truncated to a single methyl group. This compound has the very low $\mathrm{BDE}_{1}$ of $68.7 \mathrm{kcal} \mathrm{mol}^{-1}$, right at the lower limit of our design window. The $\mathrm{BDE}_{2}$ of $71.7 \mathrm{kcal}$ $\mathrm{mol}^{-1}$ is also very low and the compound will be further tested in its acetylated form in order to be protected against autooxidation.

For catechol H3 (benzo[1,3]dioxole-5,6-diol), we calculated a $\mathrm{BDE}_{1}$ of $69 \mathrm{kcal}$ mol $^{-1}$. Finally, H4 (4-methylbenzo[1,3]dioxole-5,6-diol) has a BDE 1 slightly below the 
"design window" of approximately $67 \mathrm{kcal} \mathrm{mol}^{-1}$. With this low $\mathrm{BDE}_{1}$, regeneration by ascorbate will be problematic. This will be tested and discussed in the next chapter.

\section{DPPH Kinetics and BDE}

The reaction of the phenolic antioxidants $(\mathrm{ArOH})$ with the nitrogen-centered free radical $\mathrm{DPPH}^{\bullet}$ is a second order reaction, according to Scheme 2.4:

\section{SCHEME 2.4}

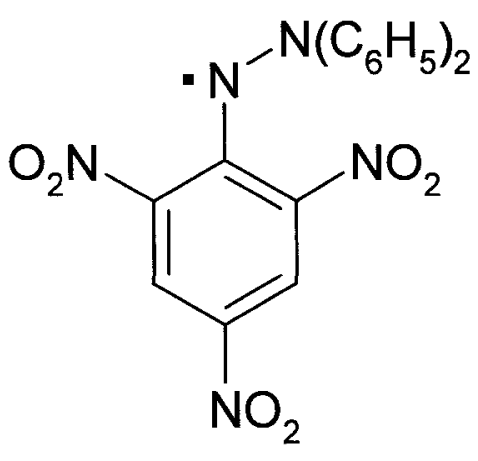

DPPH

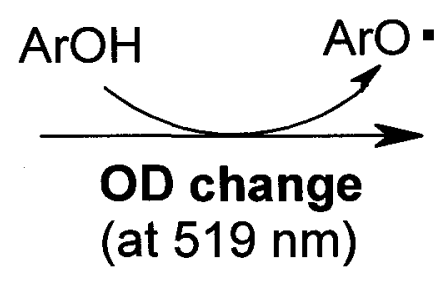

(at $519 \mathrm{~nm}$ )

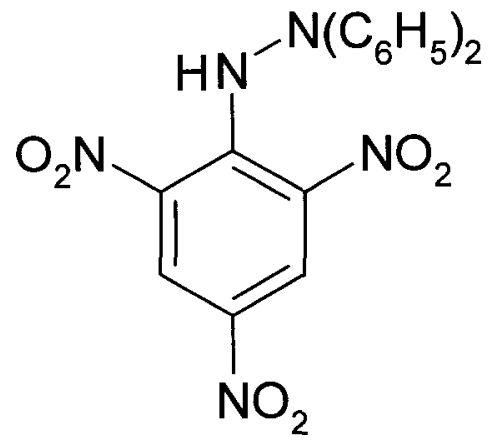

DPPH $_{2}$

The OD change was monitored at $519 \mathrm{~nm}$ (due to its odd electron DPPH gives a strong absorption at this wavelength) in presence of large excess of antioxidant at various concentrations. A decrease in absorption over time is seen (the solution starts to decolorize) due to electron pairing in presence of the antioxidant. With the exception of Vitamin E and Trolox, all other compounds are catechols having two exchangeable hydroxyl group $\mathrm{H}$ atoms. Therefore, they could react with two molecules of $\mathrm{DPPH}^{*}$. It was assumed that it is measured the rate of reaction for abstraction of the $\mathrm{H}$ atom from 
the weaker phenolic $\mathrm{OH}$. These pseudo-first order rate constants were determined by exponential fit to the decay curves near time zero.

A good correlation between rate constants and calculated BDEs was found (Figure 4). The rate of reaction with the test radical $\mathrm{DPPH}^{\bullet}$ increases (hence a better antioxidant) as $\mathrm{BDE}_{1}$ decreases. The order is $\mathrm{H}_{0}$ (least reactive with $\left.\mathrm{DPPH}^{\circ}\right)<\mathrm{H}=$ vitamin $\mathrm{E}<\mathrm{H} 1<$ $\mathrm{H} 2<\mathrm{H} 3<\mathrm{H} 4$ (most effective).

Foti et al. [32] also looked at kinetics of reactions with peroxyl radicals and obtained a good linear correlation with BDE values; this confirms that tests with the nitrogen radical $\mathrm{DPPH}^{\bullet}$ will mimic behaviour in systems which contain peroxyl radicals $\mathrm{ROO}^{\circ}$. The latter are generated biologically via normal metabolism and are known to play a role in lipid peroxidation.

\section{Correlation between $I C_{50}$ and $B D E$}

The promising compounds $(\mathrm{H} 1, \mathrm{H} 2, \mathrm{H} 3, \mathrm{H} 4)$ and some reference molecules (resveratrol, propyl gallate, EGCG and Vitamin E) were tested for their antioxidant activity in HL-60 cell culture. Differentiated HL-60 cells when stimulated by PMA produce superoxide radicals at a constant rate. The basis of our assay for superoxide is the reaction (5).

Antioxidant activity is related to $\mathrm{BDE}_{1}$ (a low $\mathrm{BDE}_{1}$ gives a more active antioxidant). Based on $\mathrm{BDE}_{1}$, I predict the following order for antioxidant activity: Resveratrol (least reactive) $<$ Trolox $<$ propylgallate $<\mathrm{H} 1<$ EGCG $<\mathrm{H} 2<\mathrm{H} 3 \sim \mathrm{H} 4$ (most reactive). According to this order, $\mathrm{H} 2, \mathrm{H} 3, \mathrm{H} 4$ are the most potent antioxidants. I found a very good correlation between $\mathrm{IC}_{50}$ and calculated $\mathrm{BDE}$. The lower the $\mathrm{BDE}$, the 
faster the reaction of antioxidant with free radicals. Thus, the $\mathrm{IC}_{50}$ of designed catechols $\mathrm{H} 2, \mathrm{H} 3, \mathrm{H} 4$ were lower than $\mathrm{IC}_{50}$ of known resveratrol and $\mathrm{EGCG}$, and more effective in quenching the free radicals produced by cells.

Next, in order to explain the mechanism by which the antioxidants suppress the free radicals produced by cells I describe the sequence of possible reactions and then I calculate the free energy changes in gas phase and in solution for the reactions in which the antioxidant $\left(\mathrm{ArOH}\right.$ or $\left.\mathrm{QH}_{2}\right)$ is directly involved (Reactions $\left.12,14,15,16\right)$ :

1. Production of superoxide by cells by stimulation with PMA (superoxide is generated at $1.9 \mathrm{nmol} / \mathrm{min} / 10^{6}$ cells, which agrees with Newburger's data) [40],

$$
\text { cells } \rightarrow \mathrm{O}_{2}^{\bullet-}
$$

The rate of superoxide production depends on how many days after differentiation the experiment is started and the viability of the cells (has to be higher than $95 \%$ ).

2. Reaction of superoxide with indicator, [3,5,50-52].

$$
\text { cytochrome } \mathrm{C}(\mathrm{III})+\mathrm{O}_{2}^{\bullet} \rightarrow \text { cytochrome } \mathrm{C}(\mathrm{II})+\mathrm{O}_{2}
$$

3. Back-reaction of oxygen with reduced iron (II) is slow,

$$
\mathrm{O}_{2}+\text { cytochrome C (II) } \rightarrow \mathrm{O}_{2}^{\bullet-}+\text { cytochrome C (III) }
$$

4. Reaction of antioxidant with indicator: electron transfer

Note that depending on the $\mathrm{pK}_{\mathrm{a}}$ of the catechols at $\mathrm{pH} 7.4$, there is also the anion form present.

$$
\mathrm{ArOH} \leftrightarrow \mathrm{ArO}^{-}
$$

Thus, $\mathrm{ArO}^{-}+$cytochrome $\mathrm{C}(\mathrm{III}) \rightarrow \mathrm{ArO}^{\bullet}+$ cytochrome C(II)

5. HAT reaction - Superoxide abstracts $\mathrm{H}$ atom from catechol

$$
\mathrm{ArOH}+\mathrm{O}_{2}^{\bullet-} \rightarrow \mathrm{ArO}^{\bullet}+\mathrm{HO}_{2}^{\bullet-}
$$


Reaction 12 does not occur, as it is too endothermic (BDE of $\mathrm{HO}_{2}{ }^{\circ-}$ is only $17 \mathrm{kcal} / \mathrm{mol}$ !).

6. Superoxide is in equilibrium with its conjugate acid $\mathrm{HO}_{2}{ }^{\circ}$ via the acid-base equilibrium:

$$
\mathrm{O}_{2}^{\bullet-}+\mathrm{H}^{+} \rightarrow \mathrm{HO}_{2}^{\bullet}\left(\mathrm{pK}_{\mathrm{a}} \text { of which is } 4.8\right)
$$

Therefore at $\mathrm{pH} 7.8 \mathrm{I}$ have $1 / 1000$ of the superoxide concentration present as $\mathrm{HO}_{2}{ }^{\circ}$. This can react with antioxidant according to the reaction:

7. HAT reaction which generates phenoxyl radical according to:

$$
\mathrm{ArOH}+\mathrm{HO}_{2}^{\bullet} \rightarrow \mathrm{ArO}^{\bullet}+\mathrm{H}_{2} \mathrm{O}_{2}
$$

The $\mathrm{pH}$ of the experiment must be known, and also should be approximately invariant over the time of the experiment.

8. Electron transfer from phenoxyl anion to hydroperoxyl radical

$$
\mathrm{ArO}^{-}+\mathrm{HO}_{2}^{\bullet} \rightarrow \mathrm{ArO}^{\bullet}+\mathrm{HO}_{2}^{-}
$$

9. Electron transfer from phenoxyl anion to oxygen

$$
\mathrm{ArO}^{-}+\mathrm{O}_{2} \rightarrow \mathrm{ArO}^{\bullet}+\mathrm{O}_{2}^{\bullet-}
$$

10. Dismutation of superoxide ion and hydroperoxyde radical $\mathrm{HO}_{2}{ }^{\bullet}[3,5]$

$$
\mathrm{HO}_{2}{ }^{+}+\mathrm{O}_{2}^{-}+\mathrm{H}^{+} \rightarrow \mathrm{HOOH}+\mathrm{O}_{2}
$$

11. Dismutation of two superoxide ions [3]:

$$
2 \mathrm{O}_{2}^{-}+2 \mathrm{H}^{+} \rightarrow \mathrm{HOOH}+\mathrm{O}_{2}
$$

The same reactions can also be written for any catechol. Knowing the $\Delta G(a q)$ for the catechol, I calculated the equilibrium constant $\mathrm{K}_{\mathrm{eq}}$ based on the formula:

$$
\Delta \mathrm{G}(\mathrm{aq})=-\mathrm{RT} \ln \mathrm{K}_{\mathrm{eq}},=-1.364 \log \mathrm{K}_{\mathrm{eq}} \text { at } 298 \mathrm{~K}
$$

The results are presented in Table 2.6. 
Table 2.6. Free energy changes $\Delta \mathrm{G}_{298}^{0}$ for various reactions which involve a phenol $(\mathrm{ArOH})$ or a catechol $\left(\mathrm{QH}_{2}\right)$ in gas phase and in solution. The constants of reactions equilibrium $\mathrm{K}_{\text {eq }}$ at $298 \mathrm{~K}$ are presented.

\begin{tabular}{|c|c|c|c|}
\hline Reaction & $\begin{array}{l}\Delta \mathrm{G}_{298}^{0}(\mathrm{~g})^{\mathrm{a}} \\
\mathrm{kcal} \mathrm{mol}^{-1}\end{array}$ & $\begin{array}{l}\Delta \mathrm{G}_{298}^{0}(\mathrm{aq})^{\mathrm{a}} \\
\mathrm{kcal} \mathrm{mol}^{-1}\end{array}$ & $\begin{array}{c}\mathrm{K}_{\mathrm{eq}} \\
\text { at } 298 \mathrm{~K}\end{array}$ \\
\hline $\begin{array}{l}\mathrm{ArOH}+\mathrm{HO}_{2}^{\bullet} \rightarrow \mathrm{ArO}^{\bullet}+\mathrm{H}_{2} \mathrm{O}_{2} \\
\mathrm{QH}_{2}+\mathrm{HO}_{2}^{\bullet} \rightarrow \mathrm{QH}^{\bullet}+\mathrm{H}_{2} \mathrm{O}_{2}\end{array}$ & $\begin{array}{l}1.95 \\
-7.9\end{array}$ & $\begin{array}{l}1.31 \\
-7.8\end{array}$ & $\begin{array}{l}10^{-1} \\
10^{6}\end{array}$ \\
\hline $\begin{array}{l}\mathrm{ArOH}+\mathrm{O}_{2}^{\bullet-} \rightarrow \mathrm{ArO}^{\bullet}+\mathrm{HO}_{2}^{\bullet-} \\
\mathrm{QH}_{2}+\mathrm{O}_{2}^{\bullet-} \rightarrow \mathrm{QH}^{\bullet}+\mathrm{HO}_{2}^{\bullet-}\end{array}$ & $\begin{array}{l}23.12 \\
13.3\end{array}$ & $\begin{array}{c}11.16 \\
8.6\end{array}$ & $\begin{array}{l}10^{-8} \\
10^{-6}\end{array}$ \\
\hline $\begin{array}{l}\mathrm{ArO}^{-}+\mathrm{HO}_{2} \rightarrow \mathrm{ArO}^{\bullet}+\mathrm{HO}_{2}^{-} \\
\mathrm{QH}^{-}+\mathrm{HO}_{2}{ }^{-} \rightarrow \mathrm{QH}^{\bullet}+\mathrm{HO}_{2}^{-}\end{array}$ & $\begin{array}{l}28.26 \\
27.74\end{array}$ & $\begin{array}{r}4.94 \\
-1.45\end{array}$ & $\begin{array}{l}10^{-4} \\
10\end{array}$ \\
\hline $\begin{array}{l}\mathrm{ArO}^{-}+\mathrm{O}_{2} \rightarrow \mathrm{ArO}^{\bullet}+\mathrm{O}_{2}^{\bullet-} \\
\mathrm{QH}^{-}+\mathrm{O}_{2} \rightarrow \mathrm{QH}^{\bullet}+\mathrm{O}_{2}^{\bullet-}\end{array}$ & $\begin{array}{l}40.78 \\
40.26\end{array}$ & $\begin{array}{l}24.48 \\
18.08\end{array}$ & $\begin{array}{l}10^{-18} \\
10^{-13}\end{array}$ \\
\hline
\end{tabular}

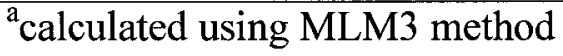

Based on calculated Keq, I concluded that reaction (14) is favoured and explained why the absorbance of cells treated with the test compound is lower than cells with no treatment. The antioxidant scavenges $\mathrm{HO}_{2}{ }^{\bullet}$ radicals and less cytochrome $\mathrm{C}(\mathrm{II})$ is formed. Therefore, I proved that an antioxidant with a lower BDE than the BDE of Vitamin E (77 kcal $\mathrm{mol}^{-1}$ ) has a higher antioxidant activity since it can more rapidly scavenge free radicals such as $\mathrm{HO}_{2}{ }^{\circ}$ or DPPH ${ }^{\bullet}$. 


\subsection{CONCLUSION}

The Bond Dissociation Enthalpy (BDE) in phenolic antioxidants is an important factor in determining the efficacy of an antioxidant; the weaker the $\mathrm{OH}$ bond, the faster will be the reaction with free radicals (peroxyl radicals). A "design window" was defined between 68-75 kcal mol ${ }^{-1}$, into which the $\mathrm{BDE}$ of active bond $\mathrm{O}-\mathrm{H}$ of the new antioxidants should fit.

In this chapter, I examined a series of target antioxidants containing a weak O-H bond, with a $\mathrm{BDE}_{1}$ within the "design window" of $68-75 \mathrm{kcal} / \mathrm{mol}$ and some outside it, which could be potentially useful for biological purposes. The compounds were then tested for reactivity with the free radical $\mathrm{DPPH}^{\bullet}$ and antioxidant activity in HL-60 cell culture. A very good linear correlation was obtained between $\log k_{\mathrm{DPPH}}$ and the $\mathrm{BDE}_{1}$ and also between $\mathrm{IC}_{50}$ and $\mathrm{BDE}_{1}$ showing that the $\mathrm{BDE}$ can be used to predict reactivity in antioxidants. The toxicity of novel synthetic antioxidants to the cells and their protective effects in cell culture will be discussed in next chapter.

\subsection{REFERENCES}

1. Gutteridge, J. M. C. (1993) Free radicals in disease processes: a compilation of cause and consequence. Free Rad. Res. Commun. 19, 141-158.

2. Harman, D. (1981), The aging process. Proc. Natl. Acad. Sci. USA 78, 7124-7128.

3. Fridovich, I. (1976) Oxygen radicals, hydrogen peroxide, and oxygen toxicity. Free Radicals in Biology (W.A. Pryor ed., New York Academic Press), 239-277.

4. Kowaltowski, A., and Vercesi, A. E. (1998) Mitochondrial damage induced by conditions of oxidative stress. Free Rad. Biol. Med.26, 463-471. 
5. Halliwell, B., and Gutteridge, J. M. C. (1999) Free Radicals in Biology and Medicine, $3^{\text {rd }}$ ed., Oxford University Press, Oxford.

6. Ozawa, T. (1997) Genetic and functional changes in mitochondria associated with aging. Physiol. Rev.77, 425-464.

7. Rice-Evans, C., and Diplock, A. T. (1993) Current status of antioxidant therapy. Free Rad. Biol. Med. 15, 77-96.

8. Lin, J-K, Chen, P.C., Ho, C.T., Lin-Shiau, S.Y., (2000) Inhibition of xanthine oxidase and suppression of intracellular reactive oxygen species in HL-60 cells by theaflavin3,36-digallate, (-)-epigallocatechin-3-gallate, and propyl gallate. J. Agric. Food Chem, $48,2736-2743$

9. Jovanovic, S. V., Steenken, S., Tosic, M., Marjanovic, B., and Simic, M. G. (1994) Flavonoids as antioxidants. J. Am. Chem. Soc. 116, 4846-4851

10. Ingold, K. U., Webb, A. C., Witter, D.;,Burton, G. W., Metcalfe, T. A. and Muller, D. P. R. (1987) Vitamin E remains the major lipid-soluble, chain-breaking antioxidant in human plasma even in individuals suffering severe vitamin E deficiency. Arch. Biochem. Biophys. 259, 224-225.

11. Burton, G. W., Joyce, A., and Ingold, K. U. (1983) Is vitamin E the only lipidsoluble, chain-breaking antioxidant in human blood plasma and erythrocyte membranes. Arch. Biochem. Biophys. 221, 281-290.

12. van Acker, S. A. B. E., Luc M.H.K., and Aalt, B. (1993) Molecular pharmacology of Vitamin E: structural aspects of antioxidant activity. Free Rad. Biol. Med. 15, 311-328. 13. Zhang, H-Y. (2005) Structure-activity relationship and rational design strategies for radical scavenging antioxidants. Curr. Comp.-Aided Drug Des. 1, 257-273. 
14. Wright, J. S., Johnson, E. R., and DiLabio, G. A. (2001) Predicting the activity of phenolic antioxidants. J. Am. Chem. Soc. 12, 1173-1183.

15. Wright, J. S., Rowley, C. N., and Chepelev, L. L. (2005) A 'universal' B3LYP-based method for gas-phase molecular properties: Bond dissociation enthalpy, ionization potential, electron and proton affinity and gas-phase acidity. Mol. Phys.103, 815-823.

16. Burton, G. W., and Ingold, K. U. (1986) Vitamin E: application of the principles of physical organic chemistry to the exploration of its structure and function. Acc. Chem. Res. 19, 194-201.

17. Packer, J. E., Slater, T. F., and Willson, R. L. (1979) Direct observation of a free radical interaction between vitamin E and vitamin C. Nature 278, 737-738.

18. Niki, E. (1987) Antioxidants in relation to lipid peroxidation. Chem. Phys. Lipids 44, 1573-1576.

19. Niki, E., Kawakami, A., Saito, M., Yamamoto, Y., Tsuchiya, J., and Kamiya, Y. (1985) Effect of phytyl side chain of vitamin E on its antioxidant activity. J. Biol. Chem. 260, 2191-2196.

20. Buettner, L. W. (1993) The pecking order of free radicals and antioxidants: lipid peroxidation, $\alpha$-tocopherol, and ascorbate. Arch. Biochem. Biophy. 300, 535-543.

21. Halliwell, B., and Whiteman, M. (2004) Measuring reactive species and oxidative damage in vivo and in cell culture: how should you do it and what do the results mean? Br. J. Pharmacol. 142, 231-255.

22. Hammond, G.S.A (1955) Correlation of reaction rates. J. Am. Chem. Soc. 77, 334338. 
23. Noguchi, N., and Niki, E. (2000) Phenolic antioxidants: a rationale for design and evaluation of novel antioxidant drug for artherosclerosis. Free Rad. Biol. Med. 28, 15381546

24. Burton, G., and Ingold, K. U. (1986) Vitamin E: Application of the principles of physical organic chemistry to the exploration of its structure and function. Acc. Chem. Res. 194, 194-201.

25. Wright, J. S. (2003) Searching for the fountain of youth. Chem. Br. 39, 25-27.

26. Wright, J. S., Carpenter, D. J., McKay, D. J.,and Ingold, K. U. (1997) Theoretical calculation of substituent effects on the $\mathrm{O}-\mathrm{H}$ bond strength of phenolic antioxidants related to vitamin E. J. Am. Chem. Soc. $119,4245-4252$.

27. Griller, D., and Ingold, K. U. (1976) Persistent carbon-centered radicals. Acc. Chem. Res., 9, 13-19.

28. Scaiano, J. C., Martin, A.; Yap, G. P. A., and Ingold, K. U. (2000) A carbon-centered radical unreactive toward oxygen: unusual radical stabilization by a lactone ring. Org. Lett. 2, 899-901.

29. Berkowitz, J., Ellison, G. B., and Gutman, D. (1994) Three methods to measure RH bond energies. J. Phys. Chem. 98, 2744-2765.

30. DiLabio, G. A., Pratt, D. A., LoFaro, A. D., and Wright, J. S. (1999) Theoretical study of $\mathrm{X}-\mathrm{H}$ bond energetics $(\mathrm{X}=\mathrm{C}, \mathrm{N}, \mathrm{O}, \mathrm{S})$ : Application to substituent effects, gas phase acidities and redox potentials. J. Phys. Chem. A 103, 1653-1661.

31. Hussain, H. H., Babic, G., Durst, T., Wright, J. S., Flueraru, M., Chichirau, A., and Chepelev, L. L. (2003) Development of novel antioxidants: Design, synthesis and reactivity. J. Org. Chem. 68, 7023-7032. 
32. Foti, M. C., Johnson, E. R., Vinqvist, M. R., Wright, J. S., Barclay, L. R. C., and Ingold, K. U. (2002) Naphthalene diols: a new class of antioxidants. Intramolecular hydrogen bonding in catechols, naphthalene diols and their aryloxyl radicals. J. Org. Chem. 67, 5190-5196.

33. Bowry, V. W., and Ingold, K.U. (1995) Extraordinary kinetic behavior of the $\alpha$ tocopheroxyl (Vitamin E) radical. J. Org. Chem. 60, 5456-67.

34. Collins, S.J., Gallo, R. C., and Gallagher, R. E. (1977) Continuous growth and differentiation of human myeloid leukaemic cells in suspension culture. Nature (London) 270, 347-349.

35. Collins, S.J., Ruscetti, F. W., Gallagher, R. E., and Gallo, R. C. (1979) Normal functional characteristics of the cultured human promyelocytic leukemia cells after induction of differentiation by dimethyl sulfoxide. J. Exp. Med. 149, 969-974.

36. Lee, S. K., Mbwambo, Z. H., Chung, H., Luyengi, L., Gamez, E. J. C., Mehta, R., G., Kinghorn, A. D., and Pezzuto, J. M. (1998) Evaluation of the antioxidant potential of natural products. Comb. Chem. High Throughput Screen. 1, 35-46

37. Collins, S.J., Ruscetti, F. W., Gallagher, R. E., and Gallo, R. C. (1978) Terminal differentiation of human promyelocytic leukemia cells induced by dimethyl sulfoxide and other polar compounds. Proc. Natl. Acad. Sci. USA 75, 2458-2462.

38. Wagner, B.A., Buettner, G.R., Oberley, L.W., C.J. Darby, C.J., and Burns, C.P. (2000) Myeloperoxidase is Involved in $\mathrm{H}_{2} \mathrm{O}_{2}$-Induced Apoptosis of HL-60 Human Leukemia Cells. J. Biol. Chem. 275, 22461-22469. 
39. Newburger, P. E., Speier, C., Borregaard, N., Walsh, C. E., and Whitin, J. C. (1984) Development of superoxide-generating system during differentiation of the HL-60 human promyelocytic leukemia cell line. J. Biol.Chem. 259, 3771-3776.

40. Newburger, P. E., Chovaniec, M. E., Greenberger, J. S., and Cohen, H. J. (1979) Functional changes in human leukemic cell line H1-60. J. Cell Biol. 82, 315-322.

41. Bhimani, R. S., Zhong, Z., Schleifer, E., Troll, W., and Frenkel, K. (1995) Human promyelocytic leukemia cells (HL-60), a new model to study the effects of chemopreventive agents on $\mathrm{H}_{2} \mathrm{O}_{2}$ production. Cancer Detec. Prevent. 19, 292-298.

42. Kweon, M. H., Hwang, H-J., and Sung, H-C. (2001) Identification and antioxidant activity of novel chlorogenic acid derivatives from bamboo (Phyllostachys edulis). $J$. Agric. Food Chem., 49, 4646-4655.

43. Spartan '02 for Windows, Wavefunction, Inc.: Irvine, CA, 2002.

44. Gaussian 98, Revision A.7, Gaussian, Inc., Pittsburgh PA, 1998.

45. Valgimigli, L., Banks, J. T., Lusztyk, J., and Ingold, K. U. (1999) Solvent effects on the antioxidant activity of vitamin E. J. Org. Chem. 64, 3381-3383.

46. Wayner, D. D. M.; Lusztyk, E.; Page, D.; Ingold, K. U.; Mulder, P.; Laarhoven, L. J. J. A.; Aldrich, H. S. (1995) Effects of solvation on the enthalpies of reaction of tertbutoxyl radicals with phenol and on the calculated $\mathrm{O}-\mathrm{H}$ bond strength in phenol. $\mathrm{J}$. $\mathrm{Am}$. Chem. Soc., 117, 8737-8744.

47. Brunmark, A., and Cadenas, E. (1989) Redox and addition chemistry of quinoid compounds and its biological implications. Free Rad. Biol. Med. 7, 435-477. 
48. Burton, G. W.; LePage, Y.; Gabe, E. J.; Ingold, K. U. (1980) Antioxidant activity of vitamin $\mathrm{E}$ and related phenols. Importance of stereoelectronic factors. J. Am. Chem. Soc. $102,7791-7792$.

49. Burton, G. W.; Hughes, L.; Ingold, K. U. (1983) Antioxidant activity of phenols related to vitamin E. Are there chain-breaking antioxidants better than $\alpha$-tocopherol? $J$. Am. Chem. Soc. 105, 5950-5951.

50. Bielski, B. H. J., Cabelli, D. E., Ruccli, R. L., and Ross, A. B. (1985) Reactivity of $\mathrm{H}_{2} \mathrm{O}_{2} / \mathrm{O}_{2}{ }^{\bullet-}$ radicals in aqueous solution. J. Phys. Chem. Ref. Data 4, 1041-1101.

51. Land, E. .J., and Swallow, A. J. (1971) One electron reactions in biochemical systems as studied by pulse radiolysis. Arch. Biochem. Biophys. 145, 365-372.

52. Bolli, R., Jeroudi, J. O., Patel, B. S., Aruoma, O. I., Halliwell, B., and Lai, E. K., and McCay, P. M. (1989) Marked reduction of free radical generation and contractile dysfunction by antioxidant therapy begun at the time of reperfusion: Evidence that myocardial "stunning" is a manifestation of reperfusion injury. Circ. Res. 65, 607-622. 


\section{Chapter 3}

Cytotoxicity and cytoprotection of synthetic catechols:

On the relationship between structure, toxicity, protection and the effect of added ascorbate 


\subsection{INTRODUCTION}

Catechols (ortho-hydroxybenzenes) and hydroquinones (para-hydroxybenzenes) are well known in biological systems, often as metabolites of simpler aromatic hydrocarbons such as benzene and being a structural unit in natural polyphenols, as potent antioxidants [1-3]. A wide variety of plants, vegetables and fruits are rich in polyphenols which have been shown to have significant benefits in chronic disease prevention [4-6]. The polyphenols such as quercetin prevent cell death by scavenging oxygen radicals [6-8], protecting against lipid peroxidation [9], and chelating metal ions $[10,11]$. Due to the presence of two exchangeable hydrogen atoms, the aromatic diols tend to be biologically reactive molecules, capable of exhibiting both anti- and prooxidant behaviour. In the previous chapter, novel antioxidants were designed to have a "window" of BDE values of the $\mathrm{OH}$ bond between $69-75 \mathrm{kcal} / \mathrm{mol}$. A group of synthetic catechols within this window were synthesized and tested for reactivity with the stable 2,2-diphenyl-1-picrylhydrazyl free radicals (DPPH) in organic solvent $[12,13]$. Then the molecules were tested using differentiated HL-60 cells for their antioxidant capacity in cell culture. The results of cell tests show them to be effective antioxidants. In order to be cytoprotective against different stressors in cells, the compounds should be non-toxic.

Therefore, in the present work I studied their cytotoxicity by using cell cultures, taking into consideration their possible pro-oxidant action. Typically, the pro-oxidant action of catechols and hydroquinones arises following autoxidation, resulting in the formation of ortho- and para-benzoquinones which are cytotoxic $[2,14,15]$. Then I tested the potential antioxidants for the protective ability in cells subjected to oxidative stress. 
There are two main cytotoxicity mechanisms associated with quinone formation $[1,2]$. In the first, Michael addition occurs between a nucleophile and the quinone at the ring position $\beta$ - to the carbonyl group. This can lead to glutathione depletion if the nucleophile is glutathione itself, or more generally to protein thiol depletion with associated loss of protein function. Thiol depletion upsets the redox environment of the cell by causing a change in the GSH/GSSG ratio, and sufficient depletion causes cell death. Another possible reaction of the quinone is the arylation of DNA bases, where the amino groups or ring nitrogen atoms on DNA bases act as the nucleophile. DNA arylation causes transcription errors which can result in tumor-initiating mutations.

The second mechanism of cytotoxicity is redox cycling, a chain reaction resulting in the continuous production of superoxide radical. One likely initiation step occurs between the catechol $\left(\mathrm{QH}_{2}\right)$ and its (inevitably present) quinone oxidation product $(\mathrm{Q})$, leading to formation of the semiquinone radical $\mathrm{QH}^{*}$ (or its conjugate base $\mathrm{Q}^{\bullet-}$, since the $\mathrm{pK}_{\mathrm{a}}$ of the semiquinone tends to be low [1]):

$$
\mathrm{QH}_{2}+\mathrm{Q} \rightarrow 2 \mathrm{Q}^{\bullet-}+2 \mathrm{H}^{+}
$$

The redox cycle begins with the first propagation step:

$$
\mathrm{Q}^{\bullet-}+\mathrm{O}_{2} \rightarrow \mathrm{Q}+\mathrm{O}_{2}^{\bullet-}
$$

In the second propagation step, $\mathrm{Q}$ can undergo a one-electron reduction by the enzyme cytochrome $\mathrm{P} 450$ reductase leading to $\mathrm{Q}^{\circ}$, according to:

$$
\mathrm{Q}+\text { reducing enzyme }+\mathrm{NAD}(\mathrm{P}) \mathrm{H} \text { cofactor } \rightarrow \mathrm{Q}^{\bullet-}+\mathrm{NAD}(\mathrm{P})^{+}
$$

The ascorbate anion, $\mathrm{AscH}^{-}$, can play a parallel role by reducing the quinone according to the electron-transfer reaction [16]:

$$
\mathrm{Q}+\mathrm{AscH}^{-} \rightarrow \mathrm{Q}^{\bullet-}+\mathrm{AscH}^{\bullet}
$$


Alternatively, ascorbate can act by $\mathrm{H}$-atom transfer to give

$$
\mathrm{Q}+\mathrm{AscH}^{-} \rightarrow \mathrm{QH}^{\bullet}+\mathrm{Asc}^{\bullet-}
$$

Regardless of whether the reduction occurs via reactions 3,4 , or 5 , (or a combination thereof), the net result of the redox cycle is a chain reaction producing superoxide anion $\left(\mathrm{O}_{2}{ }^{-}\right)$and consuming reducing equivalents in the form of $\mathrm{NAD}(\mathrm{P}) \mathrm{H}$ as well as molecular oxygen. The oxygen uptake, measured using a Clark electrode, is often used to monitor the process and to supply information about the extent of redox cycling [2].

Superoxide is a weak oxidant but it is converted by proton transfer to the stronger oxidant, the hydroperoxyl radical, its conjugate acid, according to

$$
\mathrm{O}_{2}^{\bullet-}+\mathrm{H}^{+} \rightleftarrows \mathrm{HO}_{2}^{\bullet}
$$

This factor complicates superoxide-driven chemistry because the $\mathrm{pK}_{\mathrm{a}}$ for $\mathrm{HO}_{2}{ }^{\bullet}$ is only 4.8, so the small percentage of $\mathrm{HO}_{2}{ }^{\bullet}$ present under physiological conditions may contribute to the oxidizing nature of the free radicals generated during redox cycling, as well as to participate in the dismutation of the above species to produce the strong oxidizing agent (hydrogen peroxide) [17]. Thus redox cycling will generate reactive oxygen species (ROS) in a pH-dependent manner, which is typically measured by oxygen uptake, by an increase in $\mathrm{H}_{2} \mathrm{O}_{2}$ concentration, or by the presence of lipid peroxidation products (as an indirect measure).

Another possible mechanism which can explain the toxicity of quinone is the autooxidation of $\mathrm{QH}_{2}$ in the extracellular medium as proposed by Watanabe and Forman [18]. Hydrogen peroxide is the species produced. The quinone reenters the cell and undergoes a two electron reduction to the hydroquinone; a reaction catalyzed by $\mathrm{NAD}(\mathrm{P}) \mathrm{H}$ quinone reductase according to: 


$$
\mathrm{Q}+2 \mathrm{e}^{-}+\mathrm{NAD}(\mathrm{P}) \mathrm{H} \rightarrow \mathrm{QH}_{2}+\mathrm{NAD}(\mathrm{P})^{+}
$$

The hydroquinone then is transported to the extracellular medium where is autooxidized and more hydrogen peroxide is formed.

Morita et al. [19] explained the in vitro cytotoxicity of 4-methylcatechol by the extracellular autooxidation of the catechol leading to formation of the hydrogen peroxide. A complex mechanism of the kinetics of the oxidation of naphthohydroquinones, relevant to the study of catechols, has been given by Munday $[20,21]$.

As pointed out previously [2] a rise in hydrogen peroxide concentration can usually be countered by the action of the enzyme catalase which consumes hydrogen peroxide, so redox cycling tends to be less cytotoxic than Michael addition. However, if catalase is deactivated, e.g. by azide ion, or overwhelmed by excess $\mathrm{H}_{2} \mathrm{O}_{2}$, then the cytotoxicity caused by redox cycling can increase significantly.

A rise in the intracellular concentration of hydrogen peroxide is thought to be the cause of a variety of inflammatory diseases. For example, Dopa-quinones, formed by oxidation of L-Dopa, have been shown to generate ROS by redox cycling and are correlated with development of Parkinson's disease [22,23]. The treatment of human fibroblasts with $\mathrm{H}_{2} \mathrm{O}_{2}$ leads to senescence-like features [24], and deliberate suppression of glutathione peroxidase in knockout mice also leads to accelerated senescence caused by increased concentrations of $\mathrm{H}_{2} \mathrm{O}_{2}$ [25].

In general, the presence of ascorbate anion $\left(\mathrm{AscH}^{-}\right)$would be expected to decrease the toxicity of catechols in a cellular environment due to reduction of the semiquinone, according to:

$$
\mathrm{QH}^{\bullet}+\mathrm{AscH}^{-} \rightarrow \mathrm{QH}_{2}+\mathrm{Asc}^{\bullet-}
$$


with regeneration of the catechol and formation of the ascorbate radical anion $\mathrm{Asc}^{\bullet-}$. This reaction is protective because it prevents quinone formation, and $\mathrm{Asc}^{\bullet-}$ is non-toxic due to its spontaneous or enzyme-catalyzed dismutation into $\mathrm{AscH}^{-}$and dehydroascorbic acid (DHA) which is easily reduced by the cell back to ascorbate.

Protection by ascorbate has been proven in numerous studies: For example, ascorbate needs to be maintained at sufficient levels to prevent oxidative damage in the lens of the eye, which leads to cataract formation [26]. Ascorbate also prevents autoxidation of L-Dopa and its subsequent quinone formation [27]. In endothelial cells, ascorbate reduces the effects of oxidative stress caused by menadione, resulting in the decrease loss of intracellular glutathione [28]. The toxicity of catecholic estrogens was lessened by the presence of reducing agents such as ascorbate and cysteine, again through the reduction of the semiquinone back to the parent catechol [29].

There are also situations where ascorbate can increase cytotoxicity. It is well known that ascorbate can act as a prooxidant by the reduction of iron (III) to iron (II) and subsequent Fenton chemistry to produce the highly oxidizing hydroxyl radical [17], although this has been questioned recently as to whether this is relevant to in vivo biochemistry [30]. Ascorbic acid increases cytotoxicity-induced by oxidized low-density lipoprotein and thus acts as a prooxidant, although the effect is diminished in the presence of other antioxidants such as Vitamin E [31]. Of more relevance to this paper, ascorbate has been shown to increase the rate of $\mathrm{H}_{2} \mathrm{O}_{2}$ generation in the autoxidation of some quinones [32]. Thus reaction (4) and/or (5) can accelerate the redox cycling of quinones and increase their toxicity. 
In spite of their prooxidant behaviour, catechols demonstrate antioxidant capacity by playing an important role in protection through scavenging free radicals generated during oxidative stress. [2]. Catechols donate their first hydrogen to a radical such as $\mathrm{ROO}^{\circ}$, forming the semiquinone radical and $\mathrm{ROOH}$, according to:

$$
\mathrm{QH}_{2}+\mathrm{ROO}^{\bullet} \rightarrow \mathrm{QH}^{\bullet}+\mathrm{ROOH}
$$

thus breaking the chain reaction of lipid peroxidation. The cellular reducing equivalents, ascorbate and glutathione reduce the semiquinone back to the catechol form.

Here I consider the cytotoxicity of several synthetic catechols and EGCG. H1 is a single-ring structure, 2,3,5-trimethyl-4-methoxylcatechol. H2 is the bicyclic catechol 2,3-dihydro-2,6,7-trimethyl-4,5-dihydroxybenzofuran, whose structure bears a resemblance to $\alpha$-tocopherol. I also include, in this study, the diacetylated forms, e.g. H2-Diacetate (H2-DA). H4, derived from the naturally occurring sesamol, is a methylated methylenedioxycatechol. These compounds are currently undergoing testing as potential synthetic antioxidants [13] and a study of their cytotoxicity and cytoprotection is thus part of a larger program aimed at creating superior biologically active antioxidants.

Cell viability was studied both with and without added ascorbate. The cell line chosen for cytotoxicity studies was derived from the rat adrenal pheochromocytoma cells (PC12) [33,34], a neuronal cell line that differentiates into preneuronal cells upon treatment with nerve growth factor. In the present work, I used a clone of PC12 [35] denoted PC12-AC which has two advantages: first, the cells are adherent and thus, easy to work with and second, their doubling time is faster than non-adherent PC12s [36,37]. I also used the human promyelocytic leukemia cell line HL-60 [38] to validate the redox 
cycling mechanism by an examination of reaction stoichiometry. By treatment with DMSO, the cells become analogous to neutrophils found in the human immune system and become biological generators of superoxide free radicals by stimulation with various agents [39]. Cytotoxicity was measured on PC12-AC by examination of the following experimental parameters: $\mathrm{EC}_{50}$ (effective concentration which reduces the number of viable cells by $50 \%$, as measured by the MTT assay; see below), effect of acetylation, effect of added ascorbate, the reduced to oxidized glutathione (GSH/GSSG) ratio, and the $\mathrm{H}_{2} \mathrm{O}_{2}$ response. H2-DA, H2-DA with ascorbate, and EGCG were tested for protective effects against menadione and the aqueous-phase peroxyl radical generator $\left(2,2^{\prime}\right.$-azobis (2-amidinopropane) hydrochloride (AAPH). Toxicity and protective data will be combined to create a measure of cytoprotective efficacy for each compound. Observed cytotoxicity or protection will be related to calculated molecular properties, such as the bond dissociation enthalpy of the diol (denoted $\left.\mathrm{BDE}_{1}\right)$ and its semiquinone $\left(\mathrm{BDE}_{2}\right)$ and the octanol-water partition coefficient $(\log \mathrm{P})$.

\subsection{MATERIALS AND METHODS}

\section{Materials}

$\mathrm{H} 1, \mathrm{H} 2$, and $\mathrm{H} 4$ were synthesized as described by Hussain et al. [13]. MTT (3(3,5-dimethylthiazol-2-yl)-2,5diphenyltetrazoliumbromide), RPMI 1640 medium (with L-glutamine and without bicarbonate), Penicillin/Streptomycin solution, Trypan blue solution ( $0.4 \%$, liquid, sterile-filtered, cell culture tested), epigallocatechin gallate (EGCG), dimethyl sulfoxide (DMSO), L-ascorbic acid, Hank's balanced salt solution (HBSS), sodium bicarbonate, cytochrome C (from horse heart), phosphate buffered saline 
(PBS), xylenol orange, sorbitol, ferrous sulfate, AAPH and sulfuric acid were obtained from Sigma Chemical Co. (St. Louis, MO, USA). Hydrogen peroxide was obtained from Caledon Laboratories Ltd. (Georgetown, ON, CAN). RPMI 1640, trypsin, horse serum, fetal bovine serum, newborn calf serum, and antibiotic-antimycotic were purchased from Invitrogen (Carlsbad, CA, U.S.A.). Fetal calf serum was obtained from the American Type Culture Collection (ATCC, Rockville, MD, U.S.A).

The diacetate forms of compounds (H1-DA, H2-DA and H4-DA) were prepared by reacting the diol with acetic anhydride in the presence of N,N-dimethylaminopyridine and triethylamine at the University of Ottawa. All structures were verified by ${ }^{13} \mathrm{C}$ NMR and mass spectrometry.

\section{Cell culture}

PC12-AC cells, an adherent clone of the rat adrenal pheochromocytoma cell line PC12, were a gift from Dr. Steffany Bennett (Biochemistry, Microbiology and Immunology, University of Ottawa). PC12-AC were grown in RPMI 1640 medium supplemented with 5\% newborn calf serum, 10\% heat-inactivated horse serum, containing $100 \mathrm{U} / \mathrm{mL}$ penicillin $\mathrm{G}$ sodium salt, $100 \mu \mathrm{g} / \mathrm{mL}$ streptomycin sulfate and $0.025 \mathrm{mg} / \mathrm{mL}$ amphotericin B (Invitrogen, Carlsbad, CA, U.S.A.). Cells were maintained at $37{ }^{\circ} \mathrm{C}$ in a humidified atmosphere of $5 \% \mathrm{CO}_{2}$ in air. Cells were passed at a density of approximately $5 \times 10^{5}$ cells $/ \mathrm{mL}$ twice a week with a doubling time of approximately $24 \mathrm{~h}$. Cell numbers and viability were determined by the trypan blue $(0.1 \% \mathrm{w} / \mathrm{v})$ exclusion method. 
HL-60 cells, a promyelocytic leukemia cell line (CCL-240) derived by S.J. Collins, et al. [39] was purchased from ATTC. Cells were grown in RPMI 1640 medium supplemented with $10 \%$ heat-inactivated fetal bovine serum, sodium bicarbonate $(2 \mathrm{~g} / \mathrm{l})$ and $1 \%$ Penicillin $(100 \mathrm{units} / \mathrm{ml}) /$ Streptomycin $(100 \mu \mathrm{g} / \mathrm{ml})$ solution. The cells were maintained at $37{ }^{\circ} \mathrm{C}$ in a humidified atmosphere $\left(5 \% \mathrm{CO}_{2}\right.$ in air $)$ and passed at a density of approximately $1.5 \times 10^{5}$ cells $/ \mathrm{mL}$ twice a week, with a doubling time of approximately $24 \mathrm{~h}$. Their concentration did not exceed $10^{6}$ cells $/ \mathrm{ml}$. Cell numbers and viability were determined by the trypan blue dye $(0.1 \% \mathrm{w} / \mathrm{v})$ exclusion method.

\section{Assay of MTT reduction}

PC12-AC cells undergoing exponential growth were trypsinized, counted, diluted and seeded in untreated 96-well microplates at a density of 200,000 cells $/ \mathrm{mL}(100$ $\mu \mathrm{L} /$ well). Plates were incubated for $24 \mathrm{~h}\left(37{ }^{0} \mathrm{C}, 5 \% \mathrm{CO}_{2}\right)$ to allow adherence. After incubation, the medium was discarded and replaced with fresh medium containing the compounds at concentrations ranging from 1-200 $\mu \mathrm{M}$ (test compounds were dissolved in DMSO; the final concentration of DMSO in the wells was less than $0.5 \%$ ). Cultures containing test compounds were incubated for another $24 \mathrm{~h}$. The cells were washed once with $100 \mu \mathrm{L}$ PBS and $100 \mu \mathrm{L}$ of fresh medium was added, along with $10 \mu \mathrm{L}$ MTT stock solution $(5 \mathrm{mg} / \mathrm{mL}$ in PBS). The cells were incubated for another $2 \mathrm{~h}$. MTT is reduced by live cells to a blue, water-insoluble formazan salt $[35,40-41]$. The medium was removed and the cells were lysed in $50 \mu \mathrm{L}$ DMSO, which also solubilizes the formazan. After $20 \mathrm{~min}$, the absorption values were read at $570 \mathrm{~nm}$ with background subtraction at 
$630 \mathrm{~nm}$ in a SpectroMax $340^{\mathrm{PC}}$ microplate reader (Molecular Devices Co., Sunnyvale CA USA).

Dichlorofluorescein (DCF) assay

The DCF assay is based on the oxidation of the nonfluorescent 2'7'dichlorodihydrofluorescein diacetate $\left(\mathrm{H}_{2} \mathrm{DCF}-\mathrm{DA}\right)$ to the highly fluorescent $2^{\prime} 7^{\prime}-$ dichlorofluorescein and used to detect the intracellular peroxides [42].

PC12-AC cells were pre-incubated in 96-well microplates at a density of 400,000 cells/mL for $24 \mathrm{~h}$ at $37^{\circ} \mathrm{C}$. The medium was discarded and replaced with HBSS and H2DA at various concentrations. After $2 \mathrm{hr}$ incubation, $40 \mu \mathrm{M} \mathrm{H} \mathrm{H}_{2} \mathrm{DCF}-\mathrm{DA}$ was added and the incubation continued for another $1.5 \mathrm{~h}$. After the supernatant was removed, the cells were washed and incubated with HBSS and the fluorescence of the cells was measured using a FluoStar Galaxy microplate reader (BMG LABTECH Inc., Durham NC, USA) with an excitation and emission wavelengths of $485-521 \mathrm{~nm}$ respectively.

\section{Cytochrome C assay}

The cytochrome $\mathrm{C}$ assay used to monitor superoxide production was described in Material and Methods, Chapter $2[43,44]$. Briefly, the HL-60 cells $(200,000$ cells $/ \mathrm{ml})$ were treated with $1.3 \%$ DMSO to induce granulocyte differentiation. After 5 days, the cells were harvested by centrifugation, washed twice with HBSS and plated in 96-well microplates at a concentration of ca. 500,000 cells $/ \mathrm{mL}$. The cells were pre-incubated with test compound $(20 \mu \mathrm{M})$ for 5 min prior to addition of $75 \mu \mathrm{L}$ cytochrome $\mathrm{C}$ solution in HBSS to a final concentration of $80 \mu \mathrm{M}$. Superoxide radical production was observed 
by following the colour change from ferrocytochrome C (III) to ferricytochrome C (II), which was monitored at $550 \mathrm{~nm}$ using a 96-well microplate reader.

\section{GSH and total protein determination}

The assay for glutathione is based on the reaction of reduced glutathione (GSH) with dithionitrobenzene (DTNB) [45]. PC12-AC cells undergoing exponential growth were trypsinized, counted, diluted and seeded in $10 \mathrm{~cm}$ dishes at a density of 400,000 cells $/ \mathrm{mL}(8 \mathrm{~mL} \mathrm{media/dish})$. Dishes were incubated for $4 \mathrm{~h}\left(37{ }^{0} \mathrm{C}, 5 \% \mathrm{CO}_{2}\right)$ to allow cell adherence. After incubation, the medium was discarded and replaced with fresh medium containing the compounds at concentrations ranging from $1-150 \mu \mathrm{M}$ (test compounds were dissolved in DMSO; the final concentration of DMSO in the wells was less than $0.5 \%$ ). The cultures containing test compounds were incubated for another 24 h. The cells were washed once with $5 \mathrm{~mL}$ PBS, harvested and centrifuged.

Cells were then lysed in 1:5 (w/v) ice-cold sulfosalicylic acid (previously bubbled with $\mathrm{N}_{2}$ gas for $15 \mathrm{~min}$ ), then bubbled with $\mathrm{N}_{2}$ gas for $10 \mathrm{sec}$ and centrifuged for $1 \mathrm{~min}$ at $13,000 \mathrm{~g}$ in an Eppendorf microcentrifuge. Supernatants were removed to new tubes and immediately neutralized with 9 volumes of $0.5 \mathrm{M}$ potassium phosphate (pH 6.0). Aliquots of neutralized supernatants were used for the measurement of total glutathione

equivalents $\left(\mathrm{GSH}_{\mathrm{eq}}=\mathrm{GSH}+2 \mathrm{GSSG}\right) . \mathrm{GSH}$ equivalents were determined by following the rate of reduction of DTNB by GSH at $412 \mathrm{~nm}$ and comparing this to a GSH standard curve $(0-300$ picomoles GSH). The assay medium $(100 \mu \mathrm{L})$ contained $100 \mathrm{mM}$ sodium phosphate $(\mathrm{NaPi})$ buffer $(\mathrm{pH} 7.5), 5 \mathrm{mM}$ sodium EDTA, $0.2 \mathrm{mM}$ NADPH, $0.6 \mathrm{mM}$ 
DTNB and 3.5 Units/mL glutathione reductase. The reaction was initiated with the addition of either sample or standard $(20 \mu \mathrm{L})$.

Soluble protein in tissue extracts was measured by the Coomassie blue dyebinding method [46] using the Bio-Rad protein reagent and the micro assay procedure with bovine serum albumin as the standard according to the manufacturer's instructions. Twenty $\mu \mathrm{L}$ of protein sample (pellets suspended in $200 \mu \mathrm{L}$ potassium phosphate) and 150 $\mu \mathrm{L}$ of Bio-Rad reagent (diluted 1: 4 in water) were added to the well and mixed thoroughly using a microplate mixer. After $10 \mathrm{~min}$ incubation at room temperature the absorbance was measured at $595 \mathrm{~nm}$.

\section{$\mathrm{H}_{2} \mathrm{O}_{2}(\mathrm{FOX} 1)$ Assay}

The FOX1 assay will measure all intra- and extracellular peroxides including $\mathrm{H}_{2} \mathrm{O}_{2}$; i.e. not exclusive to $\mathrm{H}_{2} \mathrm{O}_{2}$ alone. PC12-AC cells at a concentration of 400,000 cells $/ \mathrm{mL}$ were plated on 96-well microplates and incubated for $24 \mathrm{~h}$ at $37^{\circ} \mathrm{C}$. Medium was removed and replaced with $100 \mu \mathrm{L}$ HBSS buffer containing different concentrations of the test compounds. Stock solutions of compounds were prepared in DMSO and then diluted with HBSS so that the final concentration of DMSO in each well did not exceed $0.5 \%$. After incubation for $3 \mathrm{~h}$ at $37^{\circ} \mathrm{C}, 10 \mu \mathrm{L}$ of the supernatant was added to $100 \mu \mathrm{L}$ of FOX1 reagent [47] (100 mM sorbitol, $125 \mu \mathrm{M}$ xylenol orange, $250 \mu \mathrm{M} \mathrm{FeSO}_{4}, 25 \mathrm{mM}$ $\mathrm{H}_{2} \mathrm{SO}_{4}$ ), prepared $30 \mathrm{~min}$ in advance. Absorbance at $560 \mathrm{~nm}$ was read after $30 \mathrm{~min}$ incubation at room temperature. Levels of $\mathrm{H}_{2} \mathrm{O}_{2}$ in samples were compared to a standard curve of $\mathrm{H}_{2} \mathrm{O}_{2}(0-80 \mu \mathrm{M})$. 


\section{Protection against oxidative stress}

\section{a. Oxidative stress induced by menadione}

PC12-AC cells were trypsinized, counted (trypan blue), diluted and then seeded in untreated 96 -well microplates at a density of 200,000 cells $/ \mathrm{mL}(100 \mu \mathrm{L} /$ well $)$. The plates were incubated for $24 \mathrm{~h}\left(37^{\circ} \mathrm{C}, 5 \% \mathrm{CO}_{2}\right)$ to allow adherence. After incubation the medium was discarded and replaced with fresh medium containing the compounds at concentrations ranging from 1-10 $\mu \mathrm{M}$ (test compounds were dissolved in DMSO; final concentration of DMSO in the wells was less than 0.5\%). Cultures containing test compounds were incubated for another $24 \mathrm{~h}$. The used medium was then removed and replaced with fresh medium containing menadione (final concentration $50 \mu \mathrm{M}$ ) and the plates were incubated for another 2 hours.

The cell viability was assessed with MTT assay. To each well was added $10 \mu \mathrm{L}$ of MTT $(5 \mathrm{mg} / \mathrm{ml})$ and after $2 \mathrm{~h}$ incubation and lysing the cells the absorption values were read at $570 \mathrm{~nm}$ with background subtraction at $630 \mathrm{~nm}$ in a microplate reader.

\section{b. Oxidative stress induced by $A A P H$}

The 96-well microplates, prepared as previously mentioned $\left(2 \times 10^{5}\right.$ cells $\left./ \mathrm{mL}\right)$ were incubated for $24 \mathrm{~h}$ prior to use. The used medium was then replaced with fresh medium and the test compounds (in DMSO, diluted in medium) were added to the wells (at final concentrations of $0-250 \mu \mathrm{M}$ ) and incubated for $2 \mathrm{~h}$ before the addition of AAPH (final concentration $12 \mathrm{mM}$ ). After $24 \mathrm{~h}$ incubation, the cell viability was assayed using the MTT assay. AAPH has been shown to give carbon-centered radicals which rapidly add oxygen to give hydrophilic peroxyl radicals $[41,48]$. The term "Stress" is 
used to denote the absorbance (\% of Control) in the presence of AAPH (12 mM, $24 \mathrm{~h}$ incubation).

\section{Calculation of $B D E$}

The method of calculation was presented in the previous chapter (Material and Methods, Chapter 2). Briefly, for calculation of the BDE it was used the lowest-level method (LLM) described by DiLabio et al. [49]. Starting geometries were generally obtained with the Spartan '02 builder module [WaveFunction, Inc., Irvine, CA USA] using AM1; coordinates were then sent to the Gaussian 98 program for all subsequent calculations [50].

\section{Statistics}

Data are expressed as mean \pm SEM values. Competitive toxicity plots are given in Result section, e.g. Figure 3.2. A B-spline function was fitted through the data (see Figures 3.2--3.6, 3.12). Using the SEM values, two additional curves were fitted through the top and bottom of the error bars. From these an error estimate for the $\mathrm{EC}_{50}$ was derived as follows: a line was constructed at $50 \%$ of the maximum absorbance and the minimum and maximum curves intersected this line, forming intervals. The error limit of the $\mathrm{EC}_{50}$ is half of this interval. An error estimate for the cytoprotective area (CPA) was obtained as follows: a minimum and a maximum area were calculated using the minimum and maximum curves fitted through the top and bottom of the errors bars. The half of the difference between min CPA and max CPA represents the error estimate for 
the CPA. Statistical significance was assessed by using one-way ANOVA. Differences were considered significant at $p<0.05$.

\subsection{RESULTS}

Figure 3.1 shows structures for the synthetic catechols and their diacetates tested, and the known antioxidant from green tea, EGCG. The catechols were acetylated in order to be protected against extracellular autoxidation. The diacetates cross the PC12AC cell membrane and are hydrolyzed to the diols by intracellular ester hydrolases. 
<smiles>COc1c(C)c(C)c(O)c(O)c1C</smiles>

$\mathrm{H} 1$<smiles>COc1c(C)c(C)c(OC(C)=O)c(OC(C)=O)c1C</smiles>

H1-DA<smiles>Cc1c(C)c2c(c(O)c1O)CC(C)O2</smiles>

$\mathrm{H} 2$<smiles>Cc1c(O)c(O)cc2c1OCO2</smiles>

H4<smiles>CC(=O)Oc1c(C)c(C)c2c(c1OC(C)=O)CC(C)O2</smiles>

H2-DA<smiles>CC(=O)Oc1cc2c(c(C)c1OC(C)=O)OCO2</smiles>

H4-DA<smiles>O=C(O[C@@H]1Cc2c(O)cc(O)cc2O[C@H]1c1cc(O)c(O)c(O)c1)c1cc(O)c(O)c(O)c1</smiles>

Figure 3.1. Structural formulas for the synthetic catechols $H 1, H 2$, and $H 4$ and their diacetates H1-DA, H2-DA, H4-DA and EGCG = (-)-epigallocatechin gallate. 


\section{BDE and $\log P$ calculations}

The first two columns of Table 3.1 show the calculated BDE values for the first $\left(\mathrm{BDE}_{1}\right)$ and second $\left(\mathrm{BDE}_{2}\right)$ homolytic, gas-phase $\mathrm{O}-\mathrm{H}$ bond dissociation enthalpy. Columns 3 and 4 show the calculated octanol-water partition coefficient $(\log P)$ values. Thus for $\mathrm{H} 1$, for example, the first dissociation to the semiquinone $\left(\mathrm{QH}_{2} \rightarrow \mathrm{QH}^{*}\right)$ requires $74 \mathrm{kcal} \mathrm{mol}^{-1}$, whereas the second dissociation to form the quinone $\left(\mathrm{QH}^{\bullet} \rightarrow \mathrm{Q}\right)$ requires $73 \mathrm{kcal} \mathrm{mol}^{-1}$. From the Table it is clear that $\mathrm{H} 1, \mathrm{H} 2$ and $\mathrm{H} 4$ are similar in that $\mathrm{BDE}_{2}$ is comparable to $\mathrm{BDE}_{1}$.

Already from these results one can hypothesize that $\mathrm{H} 1, \mathrm{H} 2$ and $\mathrm{H} 4$ should be effective quinone formers. This is true since once the semiquinone radical has been formed they should rapidly autoxidize to form the corresponding quinone and superoxide ions.

Table 3.1. Bond dissociation enthalpy $\left(\Delta \mathrm{H}^{0}{ }_{298}\right)$ and $\log \mathrm{P}$ values for catechols and EGCG: $\mathrm{BDE}_{1}$ is for catechol $\rightarrow$ semiquinone, $\mathrm{BDE}_{2}$ is for semiquinone $\rightarrow$ quinone. $\mathrm{QH}_{2}=$ parent catechol, $\mathrm{Q}=$ quinone derived from the catechol.

\begin{tabular}{|c|c|c|c|c|}
\hline Compound & $\begin{array}{l}\mathrm{BDE}_{1} \\
\left.(\mathrm{kcal} \mathrm{mol})^{-1}\right)\end{array}$ & $\begin{array}{l}\mathrm{BDE}_{2} \\
\left(\mathrm{kcal} \mathrm{mol}^{-1}\right)\end{array}$ & $\begin{array}{l}\log P \\
\left(\mathrm{QH}_{2}\right)\end{array}$ & $\begin{array}{l}\log P^{h} \\
(Q)\end{array}$ \\
\hline H1 ${ }^{\mathrm{a}}$ & 74 & 73 & 1.25 & 0.87 \\
\hline$H 2^{\mathrm{a}}$ & 69 & 72 & 1.23 & 1.11 \\
\hline $\mathrm{H4}^{\mathrm{a}}$ & 67 & 67 & -0.13 & -0.28 \\
\hline EGCG & 71 & 74 & 2.04 & \\
\hline
\end{tabular}

${ }^{\mathrm{a}}$ See Hussain et al. [13].

${ }^{\mathrm{b}} \log \mathrm{P}$ was calculated using the Villars algorithm in the Spartan '02 program [51]. 


\section{Cytotoxicity and effect of added ascorbate in PC12-AC}

Figure 3.2 shows the cytotoxicity vs. concentration for the synthetic catechols $(\mathrm{H} 1$, $\mathrm{H} 2, \mathrm{H} 4)$ their diacetates (H1-DA, H2-DA, H4-DA) and EGCG, where the dashed line represents the effective concentration (MTT assay) for which the absorbance/cell viability is reduced to $50 \%$ of control (only cells, no treatment). There is clearly a wide range of cytotoxicity among the various catechols and their diacetates ranging from H4DA and H2 (most toxic) to H1-DA (least toxic). Even less cytotoxic is EGCG; an interesting result because this molecule contains the pyrogallol moiety which is known to autoxidize rapidly [52]. The observed order of cytotoxicity is: H2 $>$ H4-DA $>$ H2-DA $>$ $\mathrm{H} 4>\mathrm{H} 1>\mathrm{H} 1-\mathrm{DA}>\mathrm{EGCG}$, with $\mathrm{EC}_{50}$ 's of $25,26,33,43,82,103,>>200 \mu \mathrm{M}$, respectively.

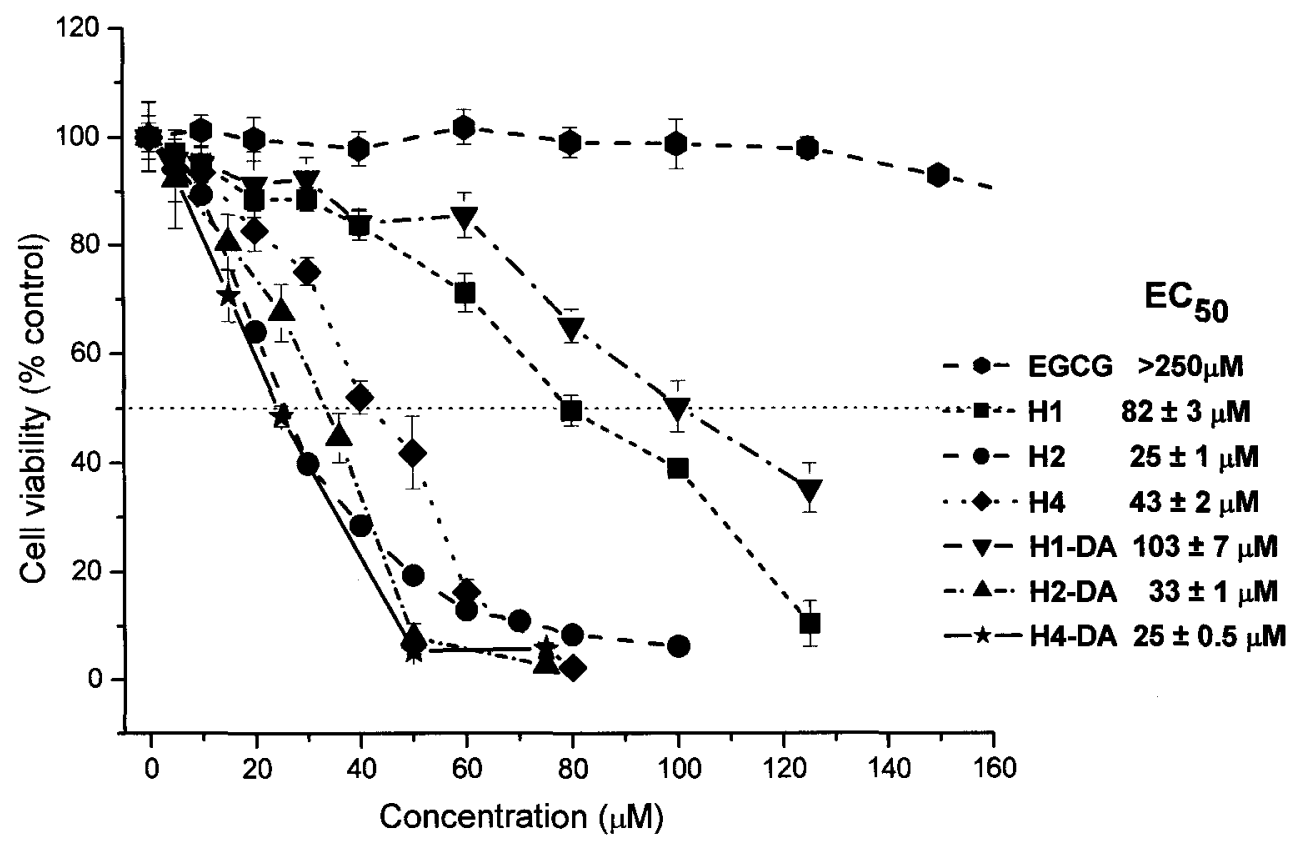

Figure 3.2. Cytotoxicity of three catechols $\mathrm{H} 1, \mathrm{H} 2, \mathrm{H} 4$ and their diacetates H1-DA, H2DA, and H4-DA and the known compound EGCG as measured by MTT assay. 
Figures 3.3a-3.5b show the number of viable PC12-AC cells, as determined using the MTT assay, for all the compounds in Figure 1 and/or their diacetates, as well as the effect of adding ascorbate at $50 \mu \mathrm{M}$. The effective concentration which reduces the number of live cells to $50 \%$ of control will be denoted $\mathrm{EC}_{50}$ in the discussion to follow.

Figures $3.3 \mathrm{a}$ and $3.3 \mathrm{~b}$ show that the cytotoxicity is somewhat greater for $\mathrm{H} 1$ than for its acetylated form $\mathrm{H} 1-\mathrm{DA}\left(\mathrm{EC}_{50}\right.$ values of 82 and $103 \mu \mathrm{M}$, respectively). Addition of ascorbate is protective for $\mathrm{H} 1(82 \rightarrow 103 \mu \mathrm{M})$, but somewhat less so for H1-DA $(103 \rightarrow$ $110 \mu \mathrm{M})$.

Figures $3.4 \mathrm{a}$ and $3.4 \mathrm{~b}$ show that $\mathrm{H} 2$ and $\mathrm{H} 2-\mathrm{DA}$ are much more cytotoxic than $\mathrm{H} 1$, with an $\mathrm{EC}_{50}$ of only $26 \mu \mathrm{M}$ and $33 \mu \mathrm{M}$, respectively. Ascorbate gives a significant protective effect to $\mathrm{H} 2$, with an $\mathrm{EC}_{50}$ value increasing to $39 \pm 0.5 \mu \mathrm{M}$ in the presence of $50 \mu \mathrm{M}$ ascorbate, and even higher protection $\left(\mathrm{EC}_{50}=52 \pm 5 \mu \mathrm{M}\right)$ in the presence of 75 $\mu \mathrm{M}$ ascorbate. For $\mathrm{H} 2-\mathrm{DA}$ the $\mathrm{EC}_{50}$ increases from $33 \mu \mathrm{M}$ to $56 \mu \mathrm{M}$ when the ascorbate is added.

By contrast, in H4 (Figure 3.5a), ascorbate increases the cytotoxicity significantly (43 $\rightarrow 32 \mu \mathrm{M}$ ), making this one of the more cytotoxic combinations of the molecules studied here. H4-DA (Figure 3.5b) has a somewhat different response, showing little difference with or without added ascorbate until the $\mathrm{EC}_{50}$ is reached, in which ascorbate is protective beyond the $\mathrm{EC}_{50}$. To try to further understand these different responses to ascorbate, we require information from the hydrogen peroxide and glutathione response curves. 


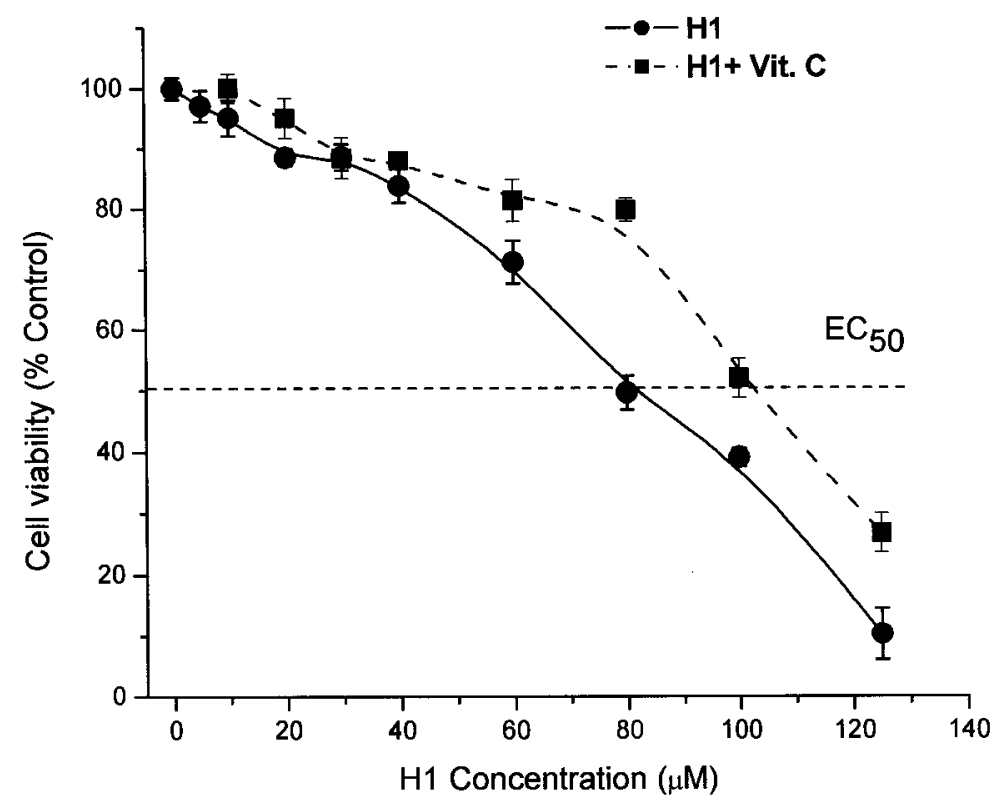

Figure 3.3a. Cytotoxicity response curve for $\mathrm{H} 1, \mathrm{H} 1+50 \mu \mathrm{M}$ ascorbate, showing \% live cells relative to control (MTT assay) vs. conc. of H1.

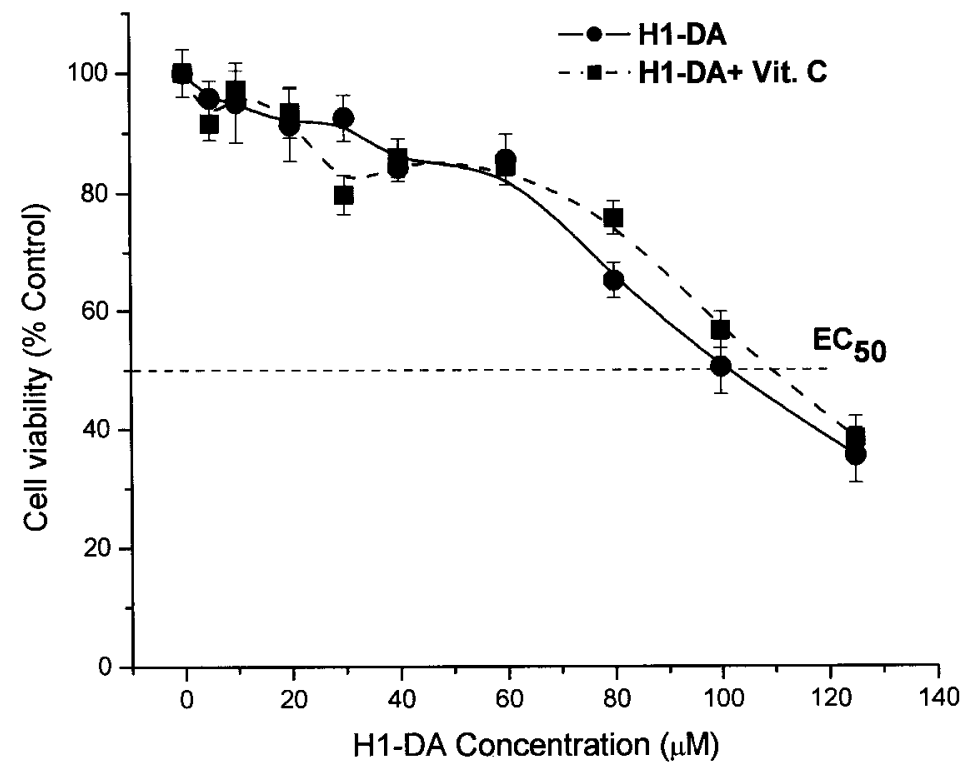

Figure 3.3b. Cytotoxicity response curve for the acetylated compound H1-DA, H1-DA $+50 \mu \mathrm{M}$ ascorbate. 


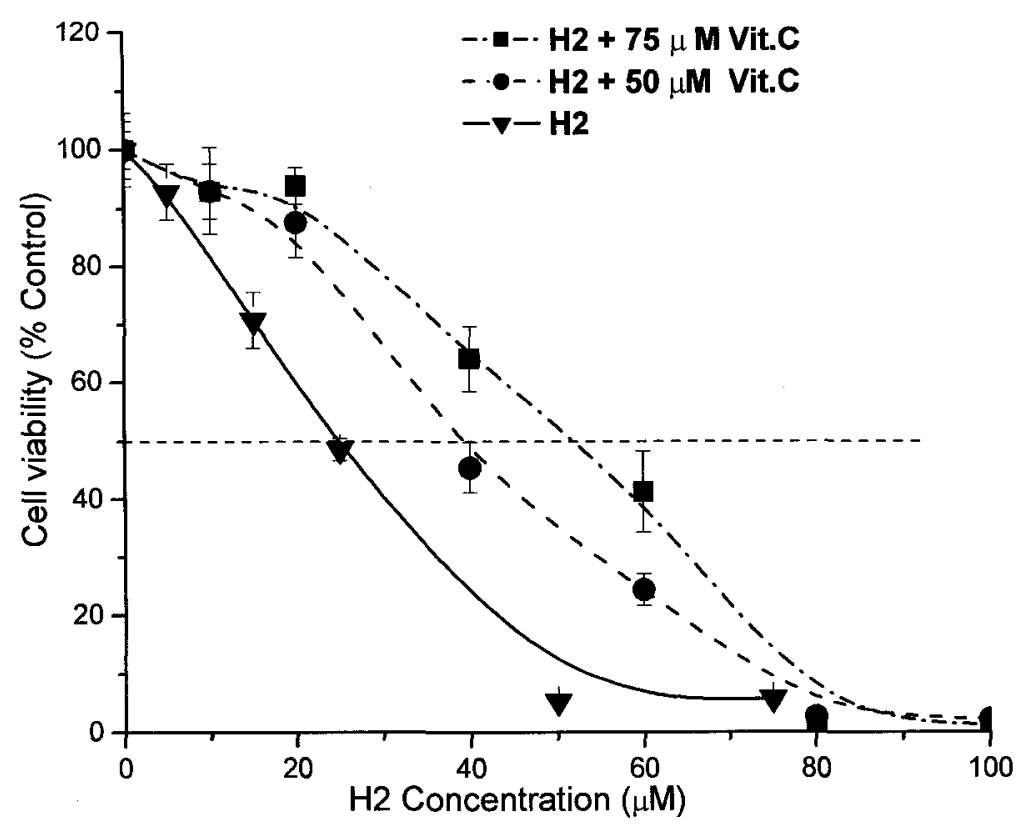

Figure 3.4a. Cytotoxicity response curve for $\mathrm{H} 2, \mathrm{H} 2+50 \mu \mathrm{M}$ ascorbate and $\mathrm{H} 2+75$ $\mu \mathrm{M}$ ascorbate.

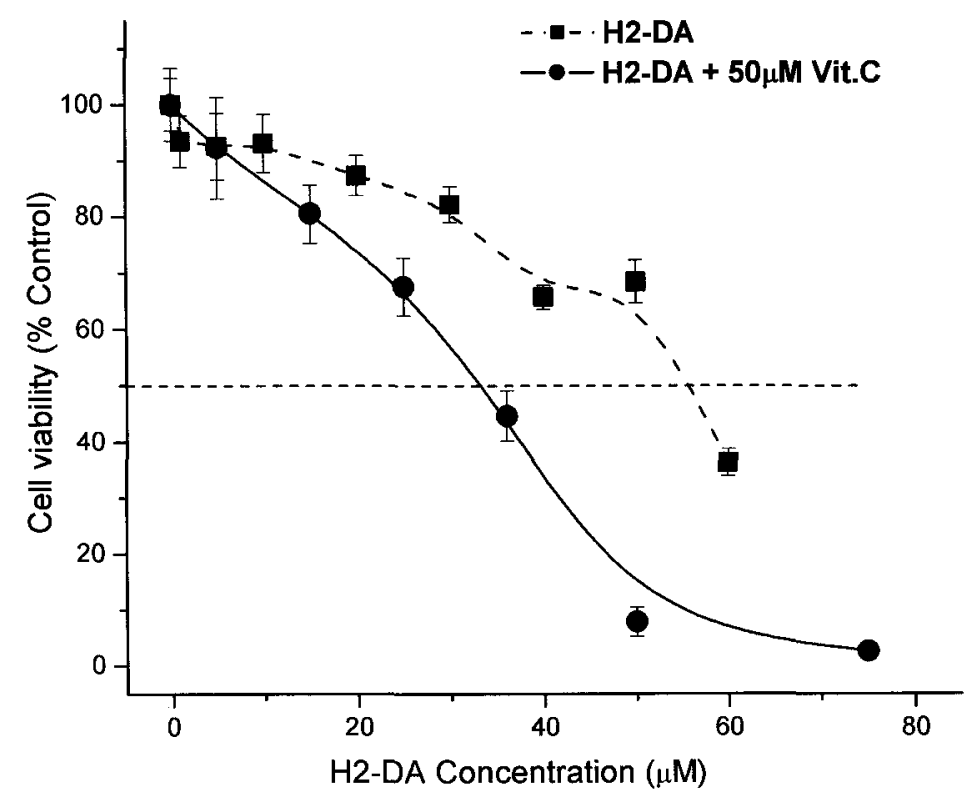

Figure 3.4b. Cytotoxicity response curve for the acetylated compound H2-DA, H2-DA $+50 \mu \mathrm{M}$ ascorbate. 


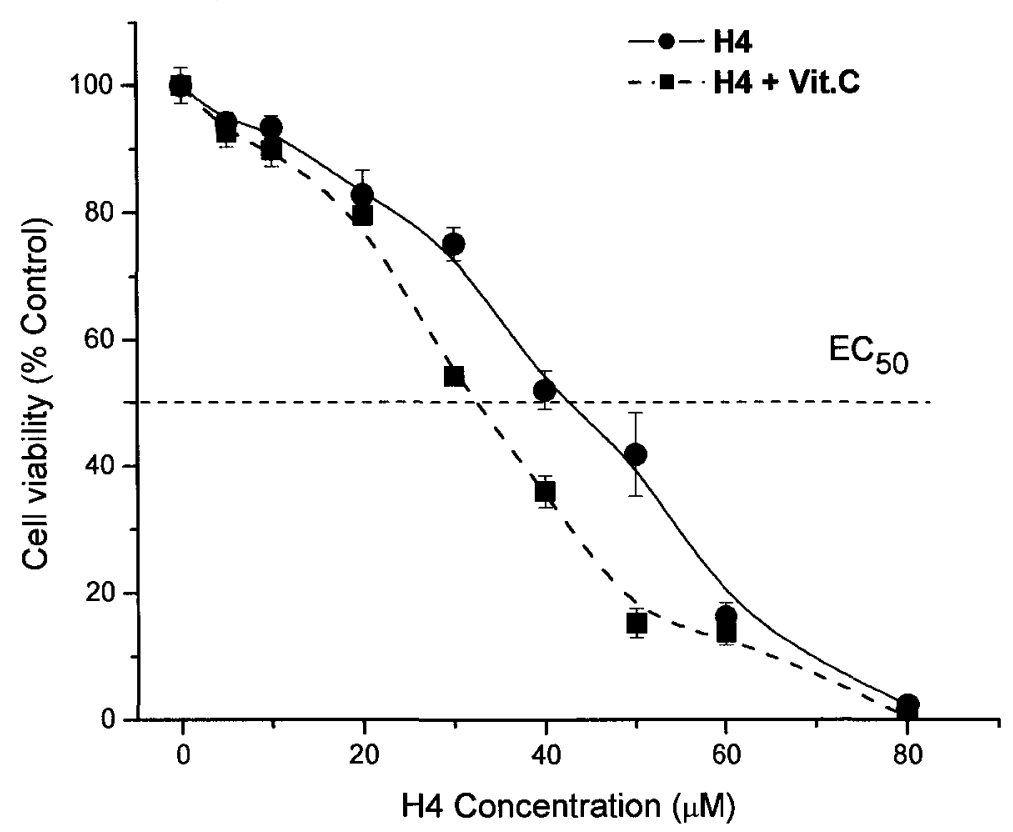

Figure 3.5a. Cytotoxicity response curve for $\mathrm{H} 4, \mathrm{H} 4+50 \mu \mathrm{M}$ ascorbate.

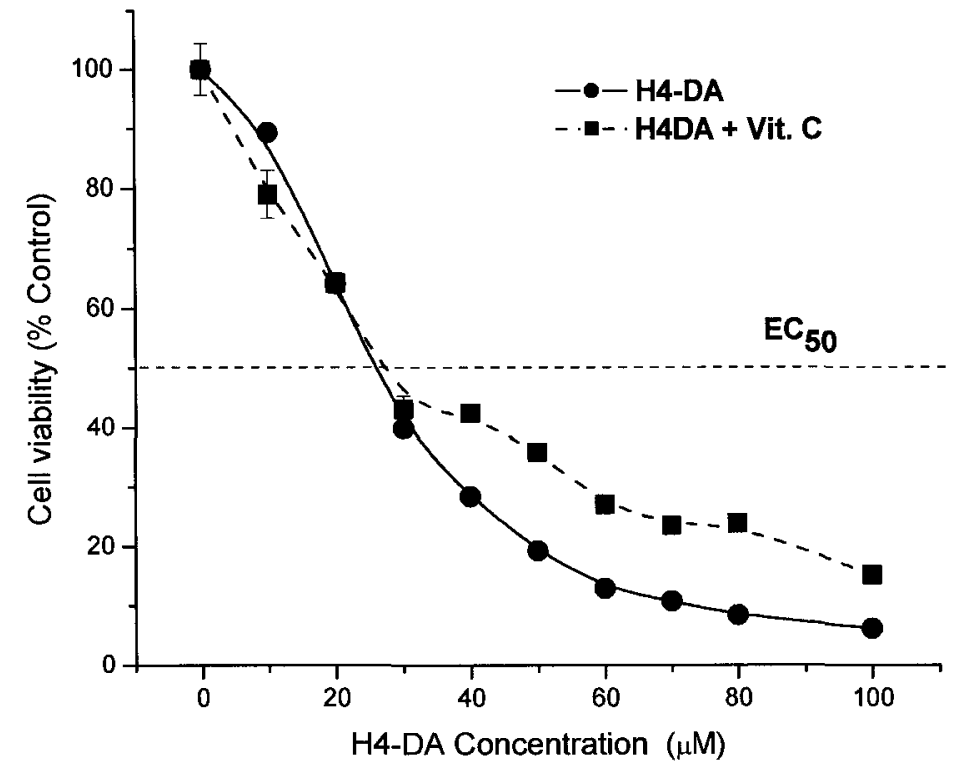

Figure 3.5b. Cytotoxicity response curve for H4-DA, H4-DA + $50 \mu \mathrm{M}$ ascorbate. 
Figure 3.6 shows the number of viable PC12-AC cells (from MTT assay) vs concentration for Vitamin C. Ascorbate anion (since solution $\mathrm{pH}=7.4$ ) is very non-toxic $\left(\mathrm{EC}_{50}>200 \mu \mathrm{M}\right)$. In this case it is known that ascorbate can dismutate into DHA which will enter the cells easily and then regenerate ascorbate [53] The concentration of $50 \mu \mathrm{M}$ Vitamin $\mathrm{C}$ that is used in the tests with catechols is non-toxic.

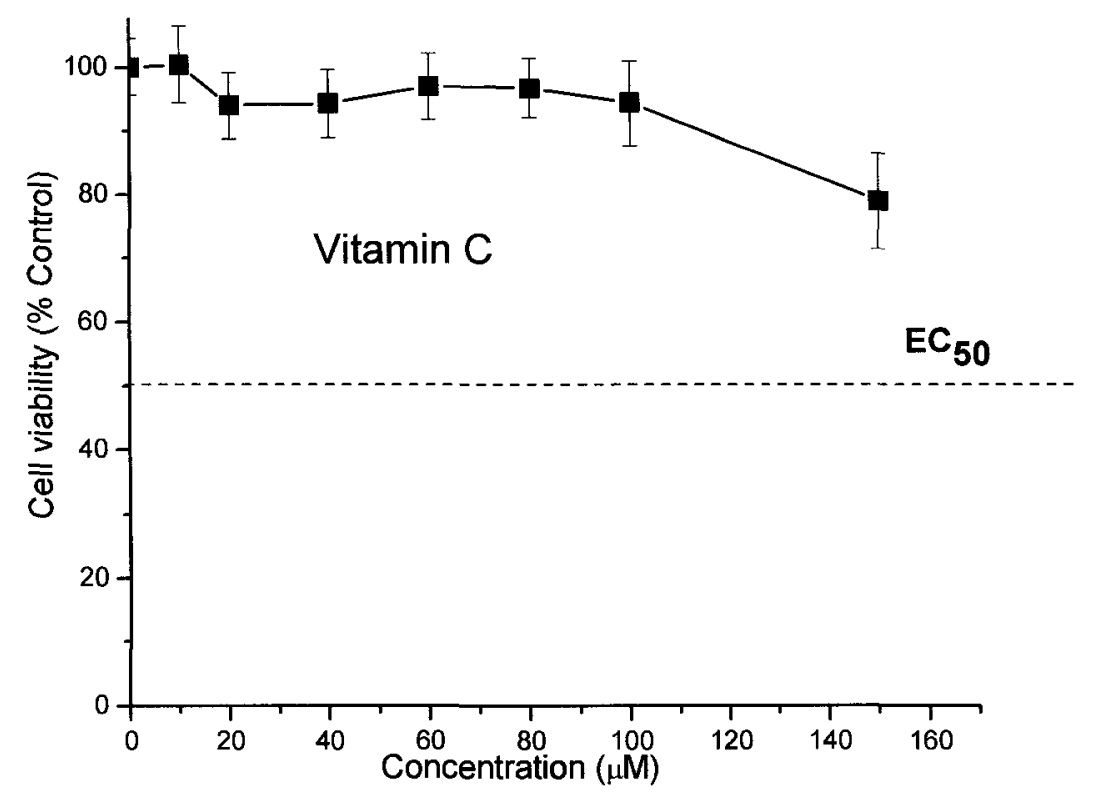

Figure 3.6. Cell viability (MTT assay) for PC12-AC cells vs concentration of Vit. C.

\section{Proof of redox cycling}

\section{a. H2-DA measurements in HL-60}

In an early phase of this work, synthetic catechols were tested for their ability to act as antioxidants, as measured by the scavenging of superoxide radicals generated by HL60 cells. [54]. Briefly, differentiated HL-60 cells were incubated either with the catechol directly (e.g. H2), or with the diacetate form (H2-DA). Cytochrome C (III) was added, and the cells were stimulated with phorbol acetate (PMA) to produce superoxide (time 
zero). The absorbance vs. time plot showed that superoxide was produced and reduced the indicator, causing a rise in absorbance. Antioxidant behavior would cause suppression in the rise of absorbance, i.e. a decreased slope. Alternatively, the HL-60 system can be studied to see whether the molecule in question can act as a pro-oxidant, by replacing the PMA in the above assay and stimulating the generation of superoxide. Using H2-DA as an example, hydrolysis inside the cell converts H2-DA into $\mathrm{H} 2$, which can then generate superoxide, detected via reduction of cytochrome C (III).

Figure 3.7 shows the results of this experiment. Differentiated HL-60 cells were incubated with H2-DA, which passed through the cell membrane in 10-15 minutes, as shown by the induction period (flat initial slope) in Figure 3.7. The graph is plateauing when the cytochrome $\mathrm{C}$ is used up.

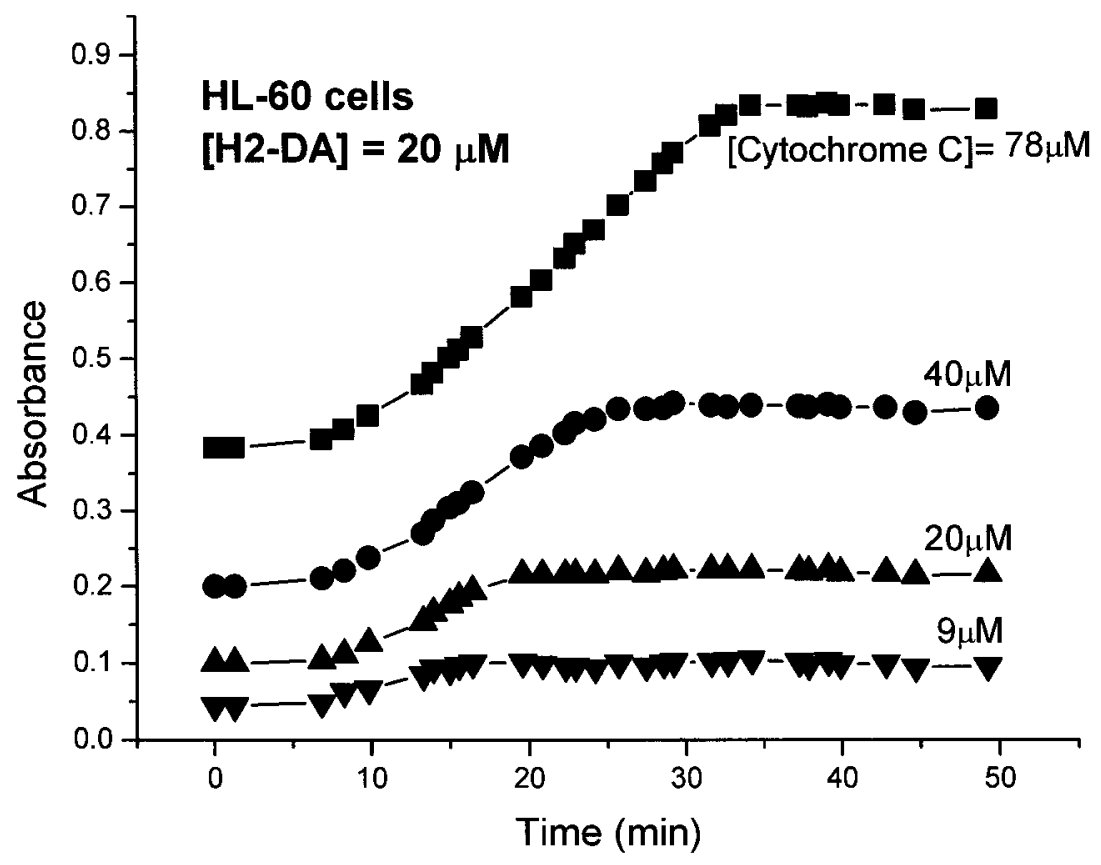

Figure 3.7. H2-DA $(20 \mu \mathrm{M})$ generates superoxide ion in differentiated HL-60 cells, causing an absorbance change due to reduction of cytochrome C(III). 


\section{b. DCF assay on PC12-AC}

Another way to monitor the intracellular oxidation mechanism is to measure the extent of intracellular oxidation products (peroxides) using a dichlorofluorescein indicator. First, PC12-AC cells were incubated in HBSS solution with $40 \mu \mathrm{M}$ DCF-DA for $1.5 \mathrm{~h}$ to load the cells. Then H2-DA was incubated with the cells for an additional 2 h. If redox cycling is occurring it should oxidize the DCF and generate a fluorescence signal.

Figure 3.8 shows the result of DCF experiments, for a concentration range of $\mathrm{H} 2-$ DA of 5 to $150 \mu \mathrm{M}$. In this experiment, the cells were washed after the last (H2-DA) incubation and prior to the fluorescence measurement. This removed all excess extracellular DCF-DA and H2-DA, as well as any DCF or $\mathrm{H} 2$ which passed from the interior to the exterior of the cell during the incubation period. There is a good doseresponse curve up to the maximum concentration of H2-DA used $(150 \mu \mathrm{M})$; beyond this range the H2-DA toxicity must increase to the point that cells are killed, and the fluorescence response will drop. From Figure 3.8 the maximum fluorescence yield is about 1400 units at $150 \mu \mathrm{M}$. 


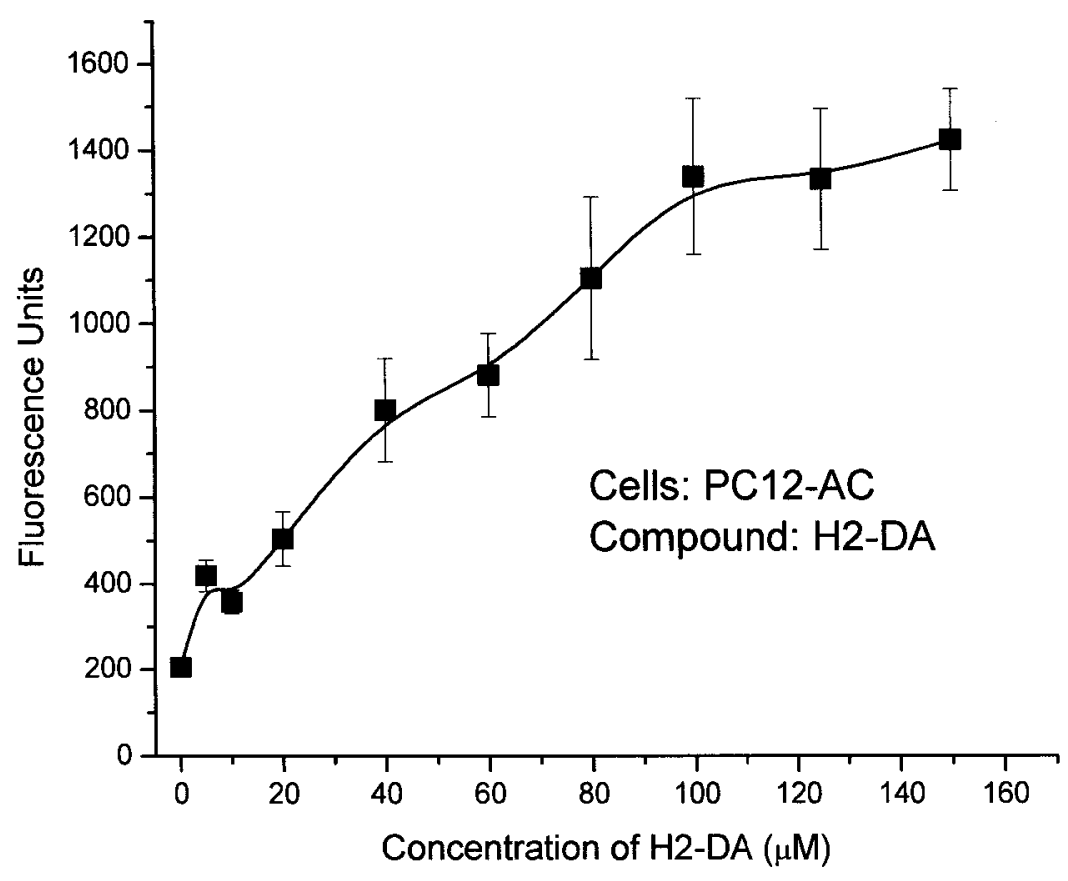

Figure 3.8. Fluorescence vs. concentration of H2-DA. PC-12AC cells $(400,000$ cells $/ \mathrm{mL}$ ), 24 hours for cell adherence. The cells were treated with H2-DA in HBSS for 2 $\mathrm{h}$, then with $40 \mu \mathrm{M}$ H2DCF-DA in HBSS, After incubation for $1.5 \mathrm{~h}$, the fluorescence was measured using a Fluogalaxi microplate reader.

\section{Hydrogen peroxide response curves}

Figures 3.9a-c (the experiments were done in Dr. Wright lab by Chichirau A.) and Figure 3.10 show the amount of $\mathrm{H}_{2} \mathrm{O}_{2}$ generated as a function of substrate concentration, for $\mathrm{H} 1$ and H1-DA, H2-DA, H4 and H4-DA, respectively, along with the effect of added ascorbate at the concentration indicated. For $\mathrm{H} 1$, the $\mathrm{H}_{2} \mathrm{O}_{2}$ response curve (Figure 3.9a) shows an essentially constant upward slope, reaching an $\mathrm{H}_{2} \mathrm{O}_{2}$ concentration of over 50 $\mu \mathrm{M}$ when $\mathrm{H} 1$ is $200 \mu \mathrm{M}$, the largest concentration we tested. Even at high concentrations, there was little change in slope, evidence that the cells must be still viable 
and undergoing redox cycling. Ascorbate caused a small reduction in $\mathrm{H}_{2} \mathrm{O}_{2}$ produced, but not until concentrations of $\mathrm{H} 1$ above $80 \mu \mathrm{M}$. The results for H2-DA (Figure 3.9b) are similar to those for $\mathrm{H} 1$. There is a strong rise in $\mathrm{H}_{2} \mathrm{O}_{2}$ with increasing $\mathrm{H} 2-\mathrm{DA}$ concentration. The $\mathrm{H}_{2} \mathrm{O}_{2}$ response is somewhat less than for $\mathrm{H} 1$, however, reaching a maximum of only $35 \mu \mathrm{M}$ at a concentration of $\mathrm{Hl}$ of $200 \mu \mathrm{M}$. A small decrease in $\mathrm{H}_{2} \mathrm{O}_{2}$ production is seen when ascorbate is added (Figure 3.9b).

The $\mathrm{H}_{2} \mathrm{O}_{2}$ response to $\mathrm{H} 4$ is qualitatively different (Figure 3.9c). There was a much smaller concentration of $\mathrm{H}_{2} \mathrm{O}_{2}$ reached with a maximum of only ca. $5 \mu \mathrm{M}$ when the concentration of $\mathrm{H} 4$ is $100 \mu \mathrm{M}$, followed by a decline. In this case, ascorbate caused an increase in production of $\mathrm{H}_{2} \mathrm{O}_{2}$.

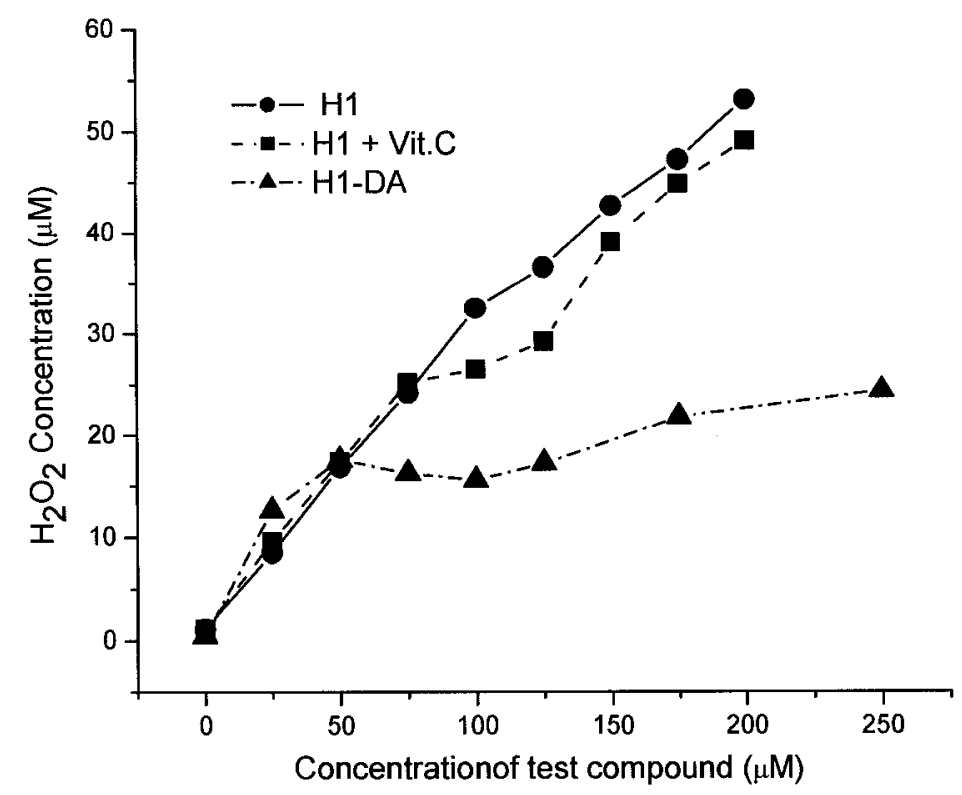

Figure 3.9a. (Extracellular) $\mathrm{H}_{2} \mathrm{O}_{2}$ concentration vs. concentration of $\mathrm{H} 1, \mathrm{H} 1+$ Ascorbate $(50 \mu \mathrm{M})$ and H1-DA. 


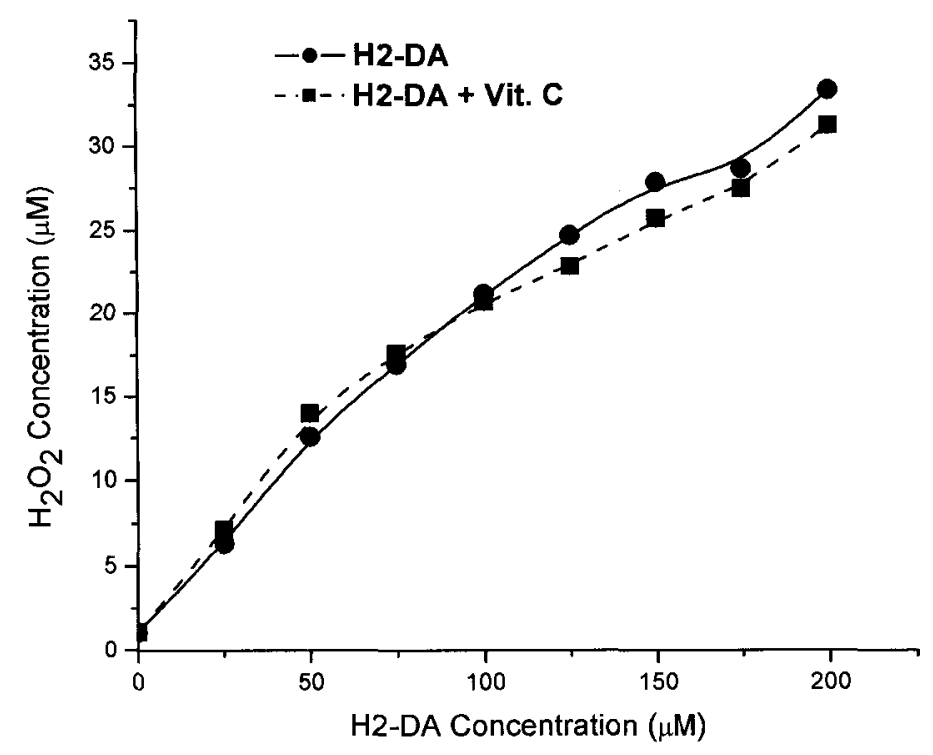

Figure 3.9b. (Extracellular) $\mathrm{H}_{2} \mathrm{O}_{2}$ concentration vs. concentration of $\mathrm{H} 2-\mathrm{DA}, \mathrm{H} 2-\mathrm{DA}+$ Ascorbate $(50 \mu \mathrm{M})$.

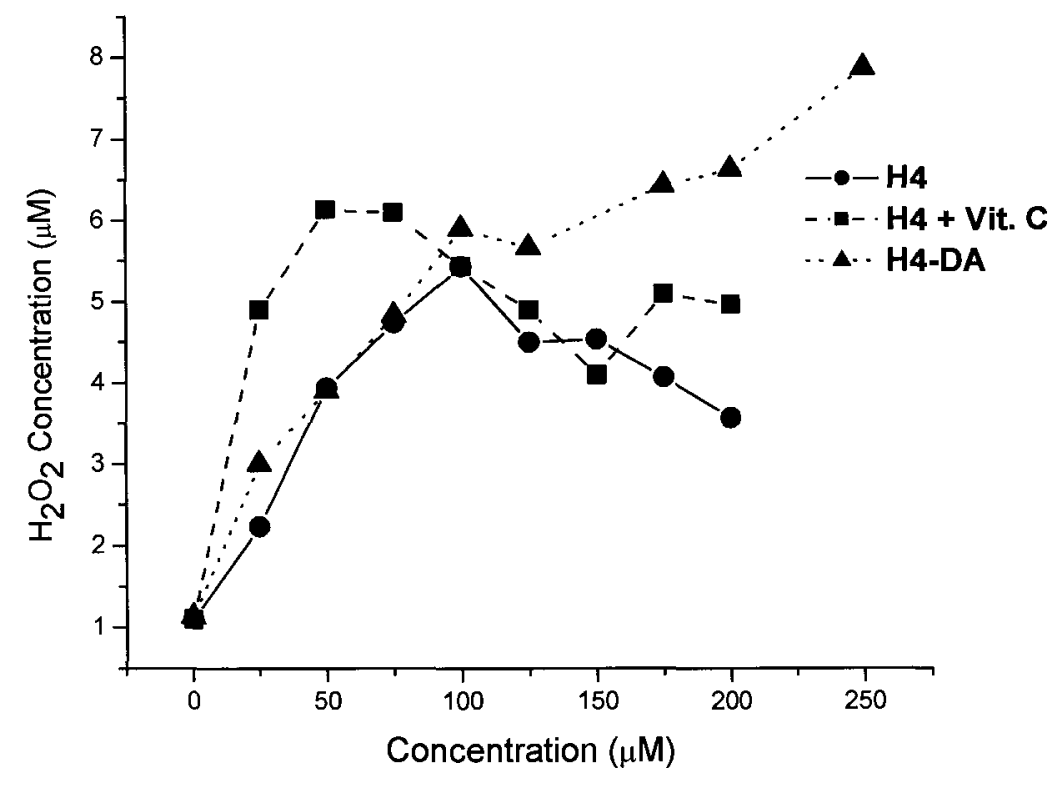

Figure 3.9c. (Extracellular) $\mathrm{H}_{2} \mathrm{O}_{2}$ concentration vs. concentration of $\mathrm{H} 4, \mathrm{H} 4+$ Ascorbate $(50 \mu \mathrm{M})$ and $\mathrm{H} 4-\mathrm{DA}$. More $\mathrm{H}_{2} \mathrm{O}_{2}$ is produced for $[\mathrm{H} 4]<100 \mu \mathrm{M}$ when ascorbate is added. 
Figure 3.10 shows the hydrogen peroxide response curves for all three catechols diacetate and EGCG drawn on the same scale, without considering the effects of added ascorbate. In these experiments, the medium was removed, then the compound was added to cells in HBSS and incubated over a variable time period (0-180 min), followed by measurement of $\mathrm{H}_{2} \mathrm{O}_{2}$ in the supernatant. H1-DA showed a slow but significant rise in time. H2-DA showed a faster rise and H4-DA and EGCG even faster still: in the case of H4-DA did we see a maximum in $\mathrm{H}_{2} \mathrm{O}_{2}$ concentration, followed by decline. $\mathrm{H}_{2} \mathrm{O}_{2}$ concentration in the case of EGCG reached a maximum of $20 \mu \mathrm{M}$ followed by decline and plateau (at $12 \mu \mathrm{M})$.

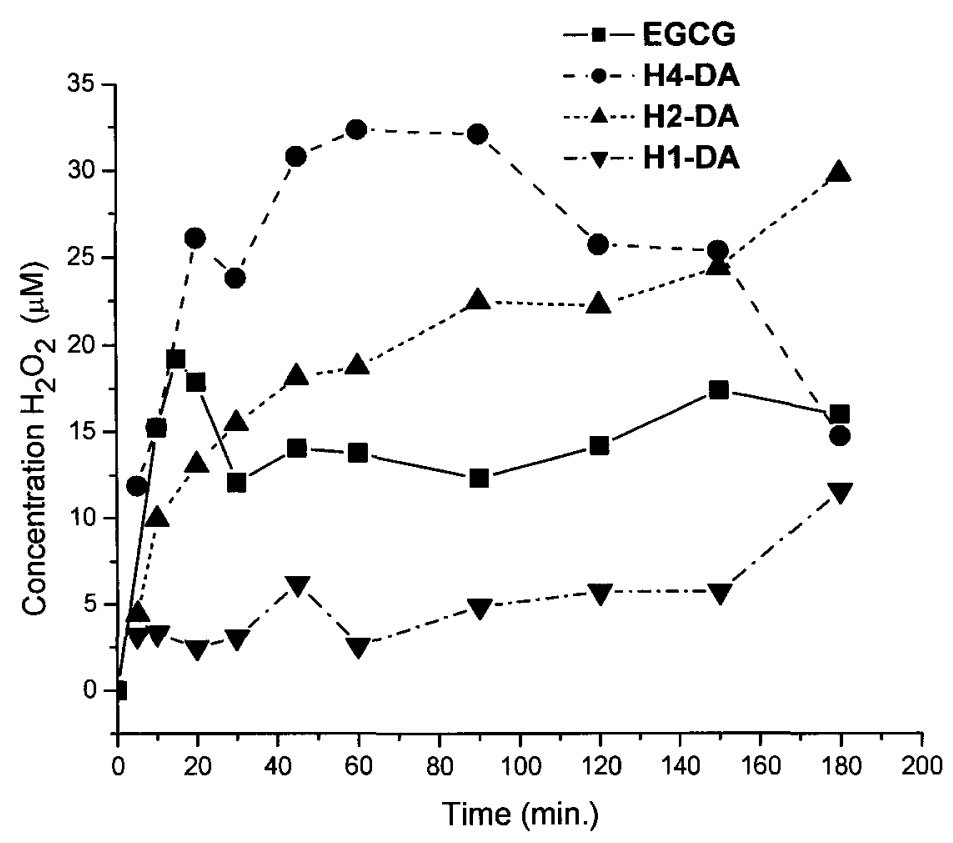

Figure 3.10. $\mathrm{H}_{2} \mathrm{O}_{2}$ response curves as a function of time (FOX1 assay) for each test compound in its diacetate form. Cytotoxicity can be almost directly related to $\mathrm{H}_{2} \mathrm{O}_{2}$ production. 


\section{GSH response curve}

The response of GSH to increasing concentrations of substrate is shown in Figure 3.11, for all three diacetates. All GSH results have been normalized to total $\mathrm{mg}$ protein. For these experiments which were carried out in medium, it is important to avoid extracellular autoxidation of the catechol, which could be catalyzed by the presence of background superoxide in the RPMI1640 medium [55]. Therefore in these experiments we used only the acetylated forms of the compounds, which were completely unreactive in the GSH assay in the absence of cells (data not shown).

For H1-DA there is a significant rise (ca. factor of two) in pmol GSH /mg protein at the highest concentration of reagent indicated. For all compounds, the statistical error increased dramatically beyond the final concentration (data not shown), due to the decreasing amounts of protein present as a result of cell death. A similar but stronger GSH response is observed for H2-DA. Here the maximum response is almost quadruple that of control, and the slope is much steeper. Thus both redox-cycling compounds are able to cause an increase in GSH concentration in the cell. H4-DA, capable of both thiol depletion and redox cycling, also shows a steep slope and a dramatic increase relative to that of control. 


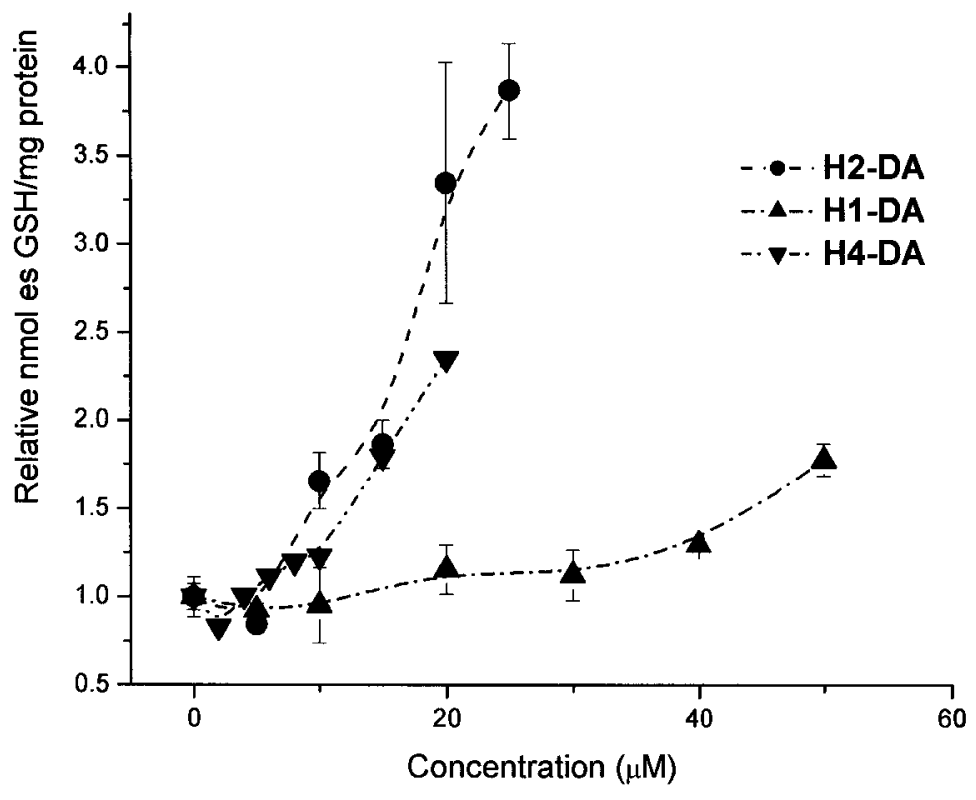

Figure 3.11. GSH response curves as a function of concentration of diacetates H1-DA, H2-DA, and H4-DA. Each plot is normalized to a per milligram protein basis. Again, closely correlated to cytotoxicity and $\mathrm{H}_{2} \mathrm{O}_{2}$ production.

\section{Protection experiments}

In order to test our new compounds for the cytoprotective effect in PC12-AC, I have chosen menadione as a classic inducer of oxidative stress. Figure 3.12 shows the cytotoxicity caused by the oxidative stressor menadione. First, the concentration of menadione and cells used in experiments had to be optimized as to obtain about $40-50 \%$ viability; this corresponds to about $47 \mu \mathrm{M}$ of menadione $\left(\mathrm{EC}_{50}\right)$ when the cell concentration is 200,000 cells $/ \mathrm{mL}$. 


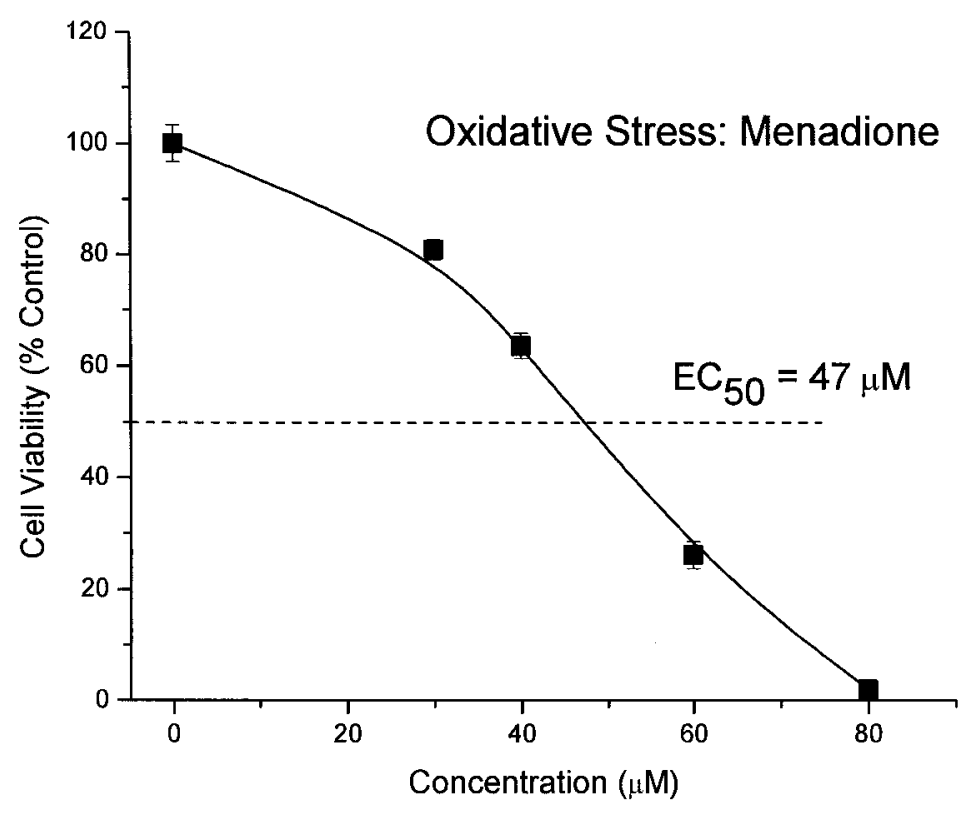

Figure 3.12. Cell viability (MTT assay) for PC12-AC cells vs. concentration of menadione.

Then I looked to see whether the antioxidants or antioxidant/Vitamin C combinations could increase the viability (i.e. protective effect) of the cells stressed with $50 \mu \mathrm{M}$ menadione (more than $60 \%$ of cells were killed). Figure $3.13 \mathrm{a}$ shows the effect of H2-DA, H2-DA + ascorbate on viability of PC12-AC cells with and without $50 \mu \mathrm{M}$ menadione. A synergistic protective response was seen for a combination of $10 \mu \mathrm{M} \mathrm{H} 2-$ DA and $50 \mu \mathrm{M}$ Vitamin C. At $10 \mu \mathrm{M} \mathrm{H} 2-\mathrm{DA}$ I see a strong protective effect $(30 \%$ to $60 \%$ viability). This increased in the presence of ascorbate (30\% to $85 \%$ viability, levels similar to that found in controls). Figure $3.13 \mathrm{~b}$ shows the experiment as before but with concentrations of $\mathrm{H} 2-\mathrm{DA}$ at $20 \mu \mathrm{M}$. At this concentration of $\mathrm{H} 2-\mathrm{DA}$, there was a slight increase in viability of cells stressed with menadione and the only protective effect was 
when H2-DA + ascorbate was used, resulting in a two-fold increase in viability. These results suggested that H2-DA has a very narrow protective "window".

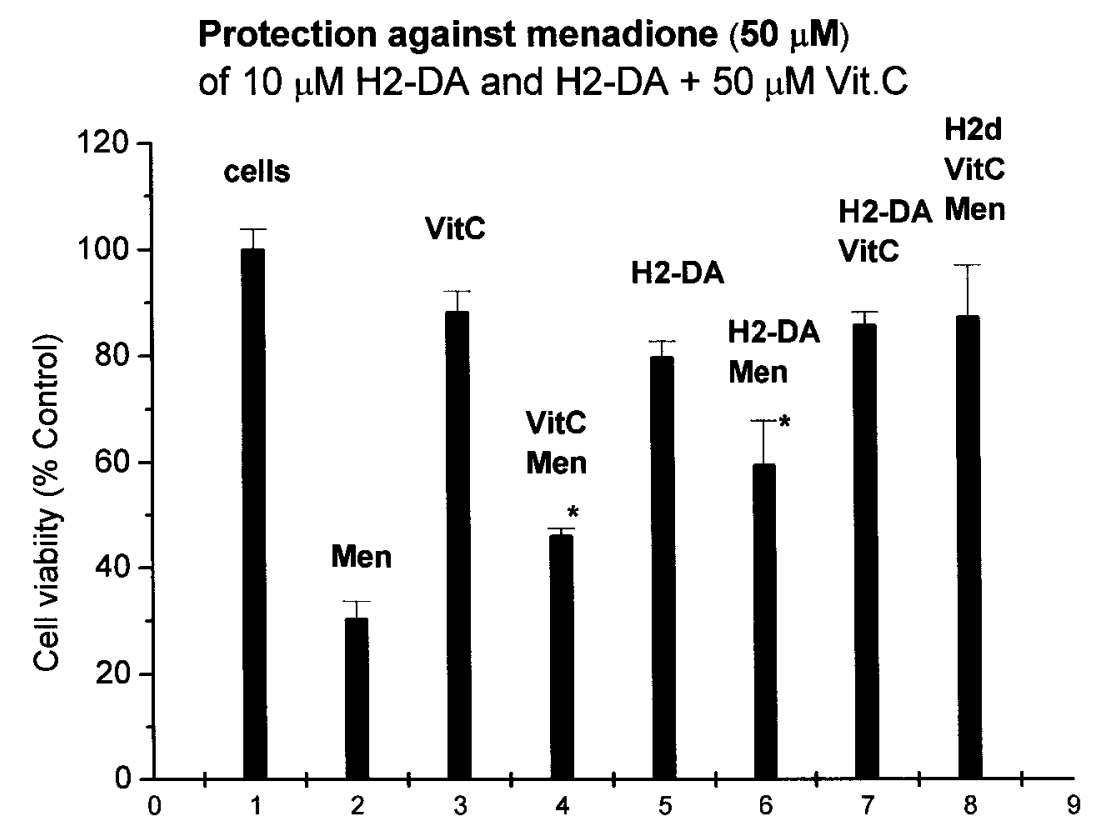

Figure 3.13a. Effects of $\mathrm{H} 2-\mathrm{DA}(10 \mu \mathrm{M})$ and $\mathrm{H} 2-\mathrm{DA}+\mathrm{Vit.C}$ on the viability of menadione $(50 \mu \mathrm{M})$-treated PC12-AC cells. Cell viability was assessed by the MTT method as described in Material and Methods. Cells were preincubated with H2-DA for $24 \mathrm{~h}$ before treatment with menadione for $2 \mathrm{~h} .\left(^{*}\right) \mathrm{P}<0.05$ compared with Menadionetreated cells. 


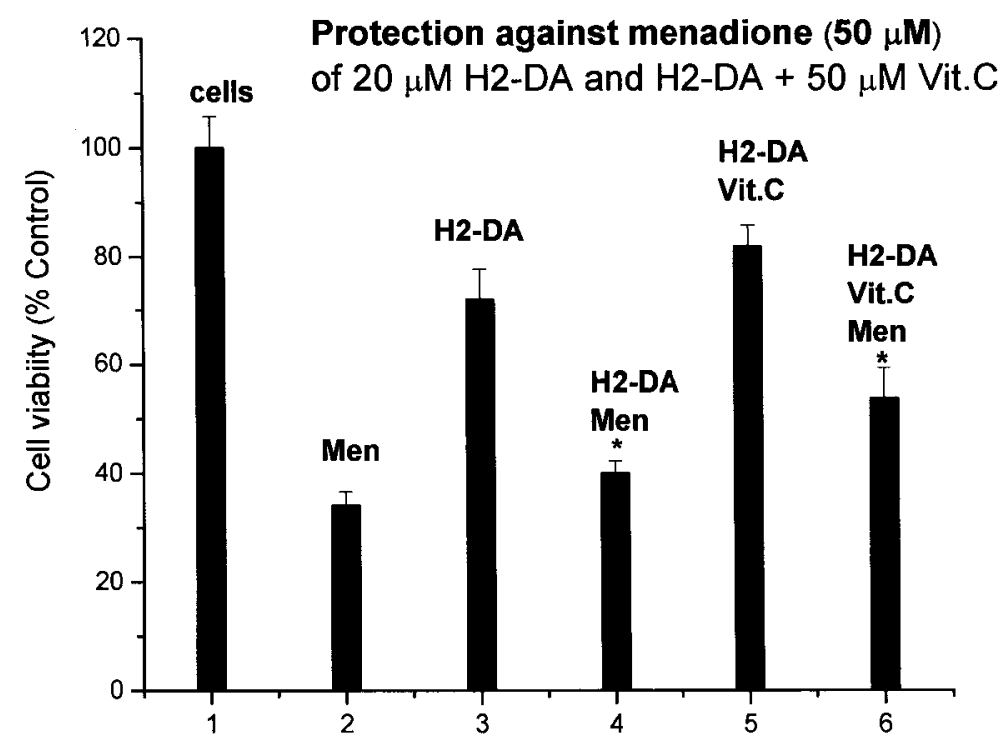

Figure 3.13b. Effects of H2-DA $(20 \mu \mathrm{M})$ and H2-DA + ascorbate on the viability of menadione $(50 \mu \mathrm{M})$-treated PC12-AC cells. Cell viability was assessed by the MTT method as described in Material and Methods. Cells were preincubated with H2-DA for $24 \mathrm{~h}$ before treatment with menadione for $2 \mathrm{~h} .\left(^{*}\right) \mathrm{P}<0.05$ compared with Menadionetreated cells.

Figure 3.14 shows the effect of H2-DA $(10 \mu \mathrm{M})$ and EGCG, respectively on viability of menadione treated PC12-AC cells. EGCG and H2-DA at the same concentration of $10 \mu \mathrm{M}$ have almost the same protective effect (the viability is increased from $\sim 35 \%$ in cells with menadione to $\sim 62 \%$ in cells treated with menadione + compound). 


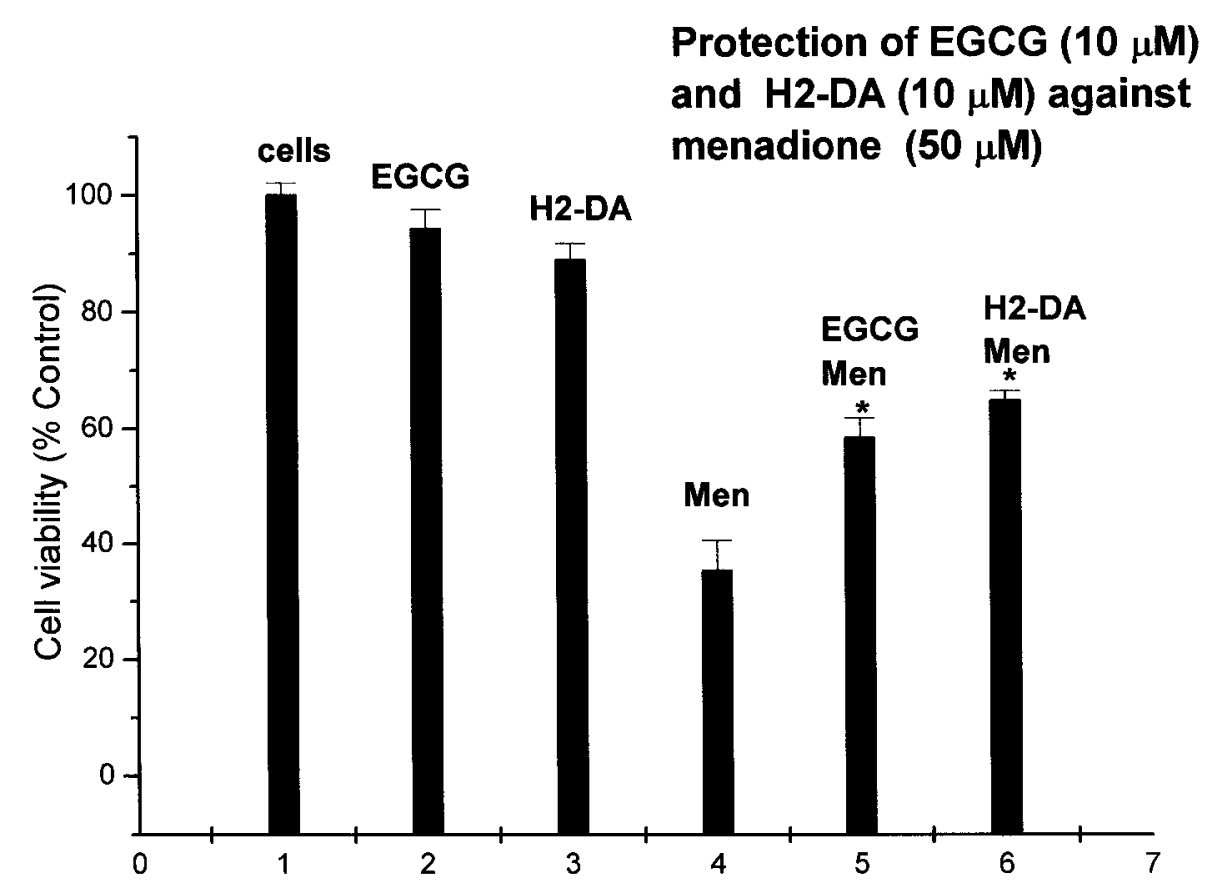

Figure 3.14. Effects of $\mathrm{H} 2-\mathrm{DA}$ and EGCG on the viability of menadione $(50 \mu \mathrm{M})$ treated PC12-AC cells. Cell viability was assessed by the MTT method as described in Material and methods. Cells were treated $10 \mu \mathrm{M} \mathrm{H2-DA}$ and EGCG, respectively for 24 $\mathrm{h}$ and then for $2 \mathrm{~h}$ with menadione. $\left(^{*}\right) \mathrm{P}<0.05$ compared with Menadione-treated cells.

When the menadione testing was concluded, it was decided to extend this work to include another oxidative stressor whose mechanism of toxicity is very well known. For this purpose AAPH was chosen, since it is commonly used to induce oxidative stress by generating peroxyl radicals (ROO•) at a relatively constant rate. For these experiments, the cells were subjected to $24 \mathrm{~h}$ exposure of AAPH over concentrations ranging from 0 to $25 \mathrm{mM}$. Cell viability was determined using the MTT assay. Figure 3.15 shows for $\mathrm{AAPH}$, the $\mathrm{EC}_{50}=10.5 \pm 3 \mathrm{mM}$. 


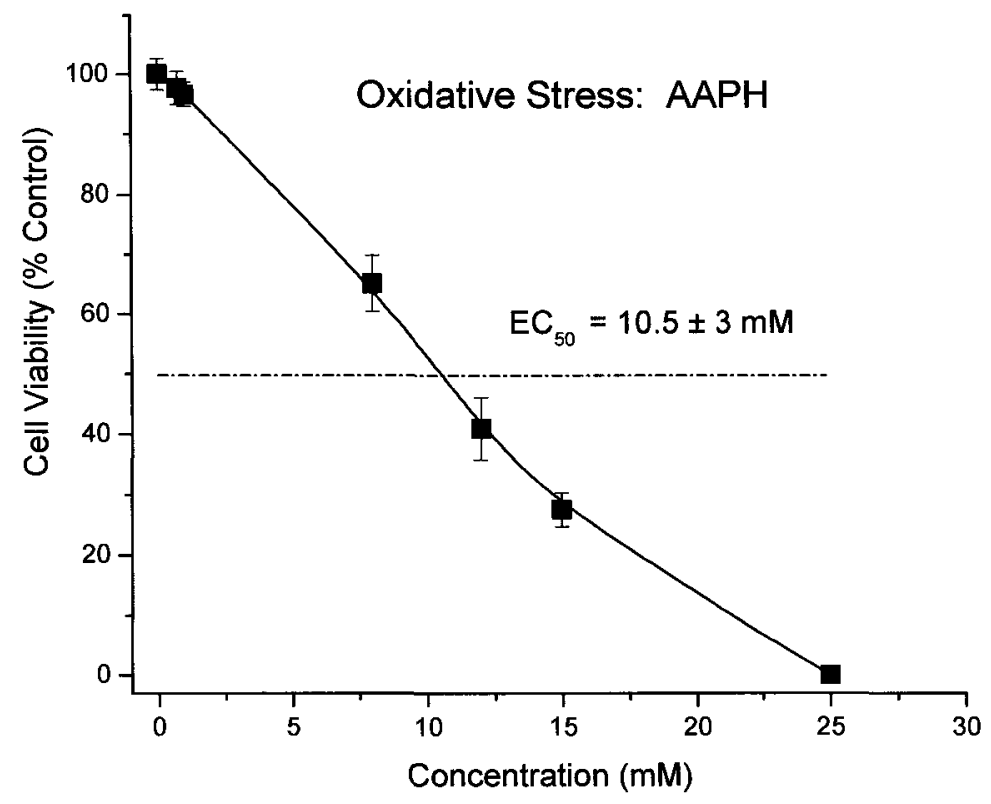

Figure 3.15. Cell viability (MTT assay) for PC12-AC cells vs. concentration of AAPH.

Figure 3.16 shows the cytoprotection of H2-DA and EGCG against oxidative stress caused by AAPH, where the AAPH concentration was $12 \mathrm{mM}$. This was sufficient to reduce cell viability to $40 \pm 5 \%$ of Control. The protective range spanned from $40 \%$ to $100 \%$ of Control. As can be seen in Figure 3.16 , the H2-DA has only a slight protective effect until $20 \mu \mathrm{M}$, beyond which its became cytotoxic. EGCG is more strongly protective attaining full protection (Control levels) at $50 \mu \mathrm{M}$. 


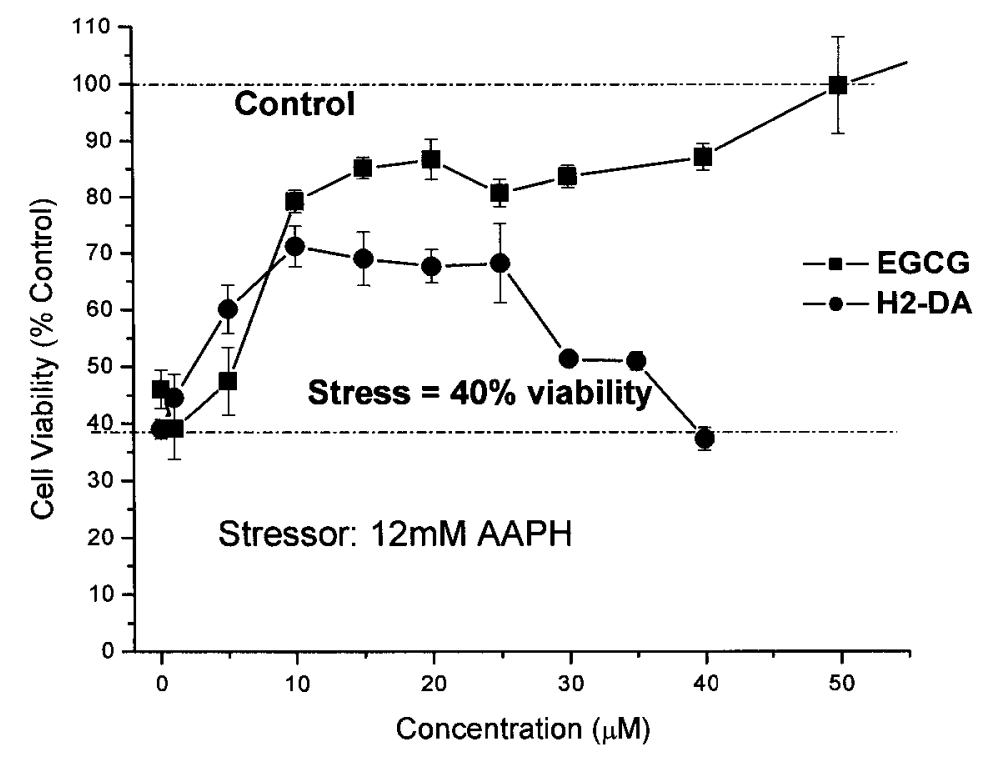

Figure 3.16. Cytoprotection of H2-DA and EGCG against AAPH-induced oxidative stress. PC12-AC cells were pre-incubated with antioxidants for $2 \mathrm{~h}$ and then for other 24 $\mathrm{h}$ with AAPH (12 mM). The viability was assessed with MTT assay described in Material and Methods.

Figures 3.17 and 3.18 show the relevant data for H2-DA and EGCG, respectively. Oxidative "stress" represented a decrease of cell viability to $40 \%$ of Control levels in the presence of AAPH (12 mM, $24 \mathrm{~h}$ incubation) and absence of compounds. The left-hand side of the Protection Zone is defined by the cytoprotection experiment (data from Figure 3.16). The cytotoxicity envelope provides the upper curve. The bottom boundary of the protective zone is determined as AAPH "stress". Figure 3.17 shows the H2-DA protective range of 0 to $40 \mu \mathrm{M}$, with the maximum peak in protection, $72 \pm 3 \%$ viability at a concentration of $15 \mu \mathrm{M}$. Figure 3.18 shows the EGCG protective range of 0 to $580 \mu \mathrm{M}$, with the maximum peak in protection, $100 \pm 5 \%$ viability at $60 \mu \mathrm{M}$ concentration. 


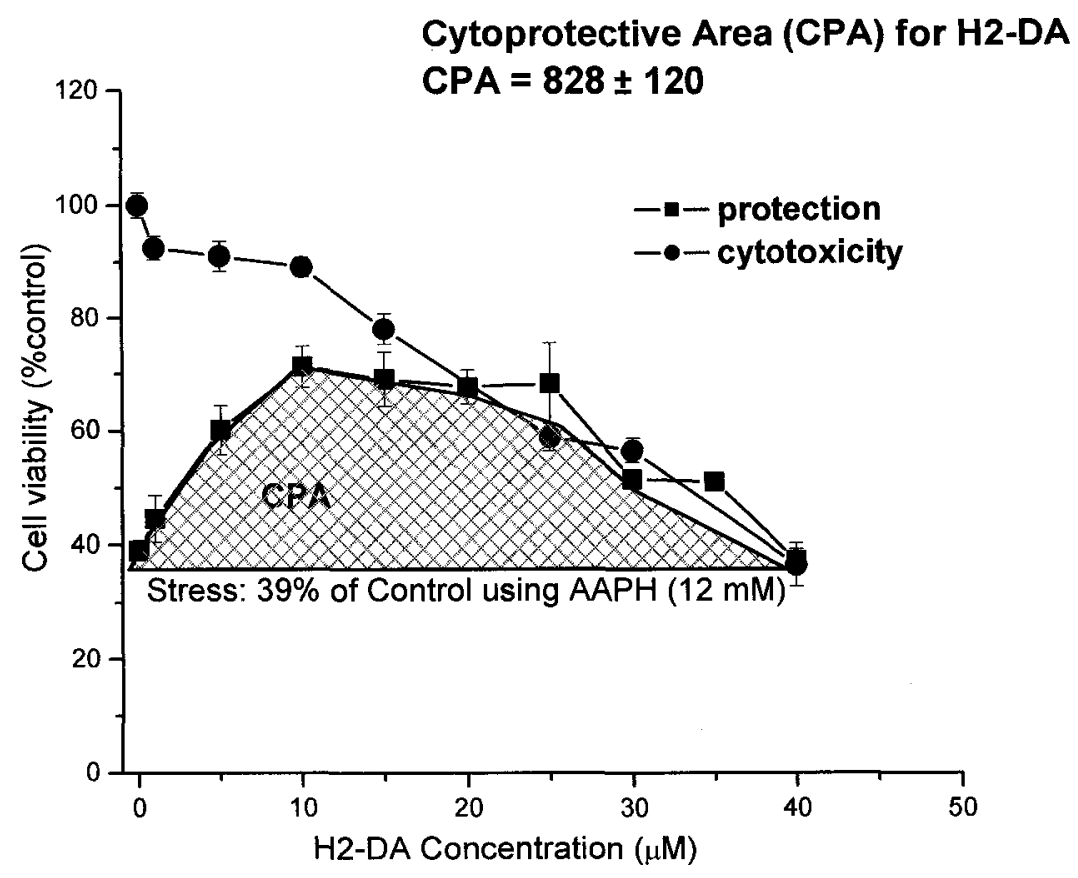

Figure 3.17. Total cytoprotective area (CPA) for $\mathrm{H} 2-\mathrm{DA}$ (the cross-hatched region) showing a narrow range of protection between 0 and $40 \mu \mathrm{M}$.

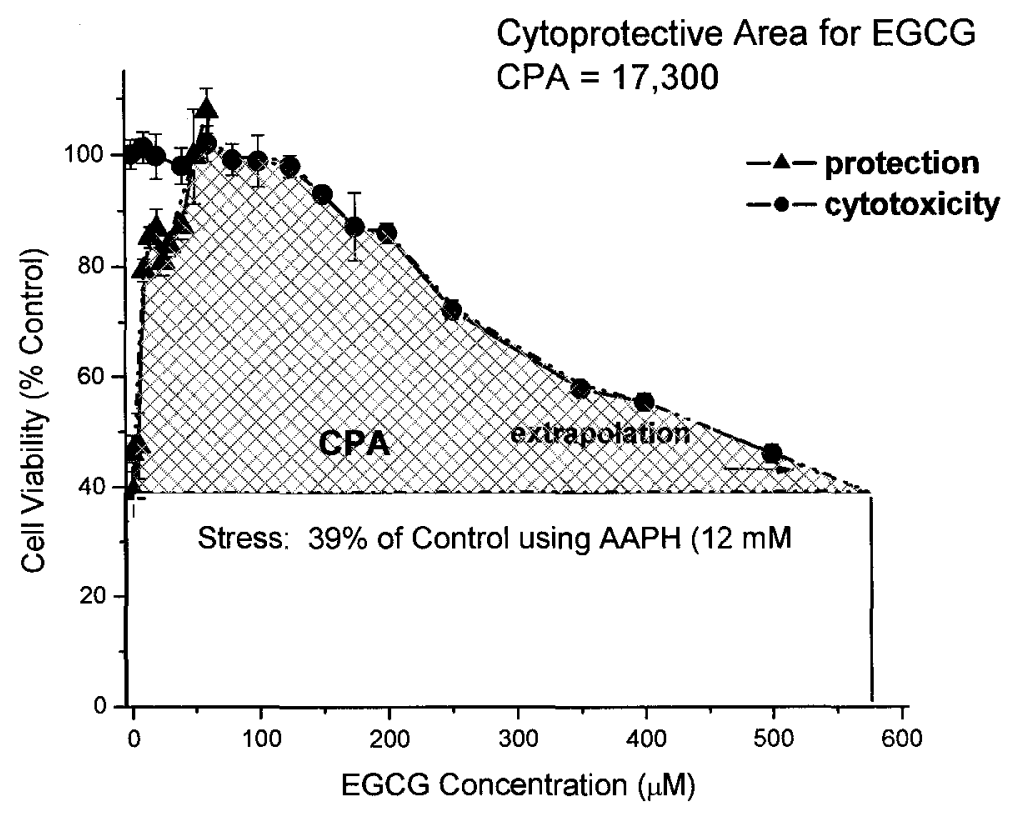

Figure 3.18. Total cytoprotective area for EGCG (cross-hatched region). 


\subsection{DISCUSSION}

\section{Predicting reaction mechanism}

The fully substituted catechols $\mathrm{H} 1$ and $\mathrm{H} 2$ are unlikely to deplete glutathione via nucleophilic addition to the corresponding quinone, since the electron donors adjacent to the carbonyl positions in the corresponding quinone (methyl or methoxyl) render these positions essentially inactive to nucleophiles (no longer electropositive). The toxicity mechanism of $\mathrm{H} 1$ and $\mathrm{H} 2$ is expected to be redox cycling, as is known to be the case for 2,3-dimethoxy-1,3-naphthoquinone [56] (see also Watanabe, 2003, for an intraextracellular variation on this theme) and/or autoxidation of the parent diol [20]. It would therefore be expected that $\mathrm{H} 1$ and $\mathrm{H} 2$ would show similar variations in $\mathrm{H}_{2} \mathrm{O}_{2}$ and $\mathrm{GSH}$ response but differ from $\mathrm{H} 4$, which has an open ring position and could react with thiols as well as undergo redox cycling. (see below).

\section{Variations in absolute cytotoxicity and $\log P$}

It is of interest to consider variations in absolute cytotoxicity, as well as the difference in cytotoxicity behavior, between a compound and its respective diacetate. A previous comparison of this type was made on a series of catechols and hydroquinones related to butylated hydroxyanisole by Lam and coworkers [57]. These authors examined the cell lines P388 and KB and looked at the effect on cytotoxicity for both acetyl (monoand di-) substitution, as well as the effect of replacing an $\mathrm{OH}$ group by an $\mathrm{OCH}_{3}$ (methoxy) group. Their most toxic compound was 3-tert-butyl-5-methoxy-catechol (their compound 5), with an $\mathrm{EC}_{50}$ of $0.09 \mu \mathrm{g} / \mathrm{mL}$ in P-388 cells. Considering only the P-388 data, they found that removing the tert-butyl significantly raised the $\mathrm{EC}_{50}$ to $1.6 \mu \mathrm{g} / \mathrm{mL}$ 
(compound 9). In the case of the catechol, 6-tert-butyl-3-methoxy-catechol, monoacetylation increased the $\mathrm{EC}_{50}$ from 0.56 to 2.70 and full acetylation increased it further to 3.70. Similar trends were noted in KB cells.

Based on these data Lam et al. [57] concluded that the presence of a tert-butyl group enhanced the cytotoxicity, whereas mono and diacetylation made the compounds less cytotoxic. Figure 19 shows compounds 5 and 9 from their study.

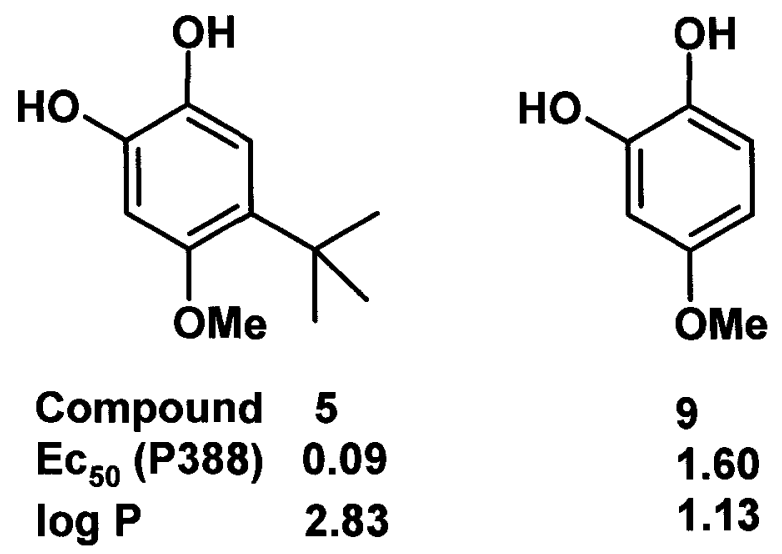

Figure 3.19. Structure of compounds 5 and 9 [57].

We calculated $\log \mathrm{P}$ for their compounds as described in Table 1 and obtained values of 2.83 and 1.13 for compounds 5 and 9 respectively. This is a very significant difference due to the added tert-butyl group in compound 5, which is therefore much more lipid-soluble than compound 9. As shown by Moridani et al. [58] in a QSAR study of cytotoxicity of phenols in hepatocytes, a leading term in the cytotoxicity correlation is $\log \mathrm{P}$, i.e. the higher the lipophilicity, the greater the cytotoxicity (and hence the lower the $\mathrm{EC}_{50}$ ). Although the tert-butyl substituent (an electron donor and a sterically bulky group) renders the compound 5 less susceptible to Michael addition, this is clearly a less important factor as compound 5 is far more cytotoxic than compound 9 . 
Our data show $\mathrm{EC}_{50}$ 's increasing in the compound order of $\mathrm{H} 2, \mathrm{H} 4, \mathrm{H} 1, \mathrm{EGCG}$ with values of $25,43,80,>250 \mu \mathrm{M}$, respectively whereas their respective $\log \mathrm{P}$ values are $1.23,-0.13,1.25,2.04$, respectively (Table 3.1). Thus the observed order of cytotoxicity of the compounds is $\mathrm{H} 4>\mathrm{H} 2>\mathrm{H} 1>>\mathrm{EGCG}$, whereas the predicted order using $\log \mathrm{P}$ values is $\mathrm{EGCG}>>\mathrm{H} 1 \approx \mathrm{H} 2>\mathrm{H} 4$; the opposite of observed order. Evidently differences in cytotoxicity arising through different reaction mechanisms far outweigh simple physical variables like lipid solubility.

The lipophilicity of the quinones was found to be similar to that of the parent catechols, to within half a $\log$ unit (Table 1). This means that transport into and out of the cell will be similar for both catechols and quinones, i.e. there is no difference between the reduced (catechol) and oxidized (quinone) forms with respect to transport through the cellular membrane.

\section{Effect of acetylation or methoxylation on cytotoxicity}

Not surprisingly, fully methoxylated compounds were the least toxic in the data set of Lam et al. [57], since no quinone formation is possible, eliminating both thiol depletion and redox cycling mechanisms. Thus, for example, Miller et al. [59] have shown that damage due to catechol oxidation in neurons could be prevented by $O$ methylation (conversion of $\mathrm{OH}$ into $\mathrm{OCH}_{3}$ ), which reduces the ability to oxidize the catechols. The acetylation data of Lam et al. are not as easy to explain, since nonspecific intracellular ester hydrolases would be expected to quickly catalyze formation of the catechol, such that the only difference between acetylated or non-acetylated compounds would be the presence of an induction period, which is the time required for hydrolysis of 
acetyl groups. Evidently this hydrolysis needs to be monitored in each system, since differences between acetylated and non-acetylated molecules are even more pronounced in KB cells. Certainly if an acetyl group is not released then a catechol, for example, is unable to autoxidize and begin a redox cycle, which would drastically decrease its cytotoxicity. The time involved in measuring cytotoxicity therefore becomes relevant; if the time scale is too short (e.g. minutes instead of hours) then the delay time for hydrolysis will become a factor and cytotoxicity will be a variable of time of incubation.

In our experiments, the cytotoxicity of all compounds was determined over a $24 \mathrm{~h}$ time period. This long incubation period has the advantage of minimizing any time lags due to hydrolysis by esterases. Thus I would expect the diacetate toxicity to be close to that of the unsubstituted compound. However, I do see significant differences between the compounds and their diacetates. For example, I find H1-DA to be significantly less toxic than $\mathrm{H} 1\left(\mathrm{EC}_{50}=100\right.$, vs. 80 for $\left.\mathrm{H} 1\right)$ (Figure 3.3 ), whereas the diacetate H4-DA is more toxic than $\mathrm{H} 4\left(\mathrm{EC}_{50}=26\right.$ vs. 43 , respectively)(Figure 3.5$)$. This may be a factor of a) the ability of the compound to enter the cell and b) the ability of the compound to form a radical. It goes back to the arguments of protection/toxicity afforded inside/outside of the cell. For example, $\mathrm{H} 4$ becomes MORE toxic as it enters the cell and becomes a radical whereas $\mathrm{H} 1$ enters the cell and does not (Figure 3.10). In fact, in the case of H1 where the tested concentrations are necessarily high due to the high $\mathrm{EC}_{50}$, I observed formation of a red color in the microplate wells. Since the cytotoxicity tests were carried out in medium, it is probable that this differential toxicity must have come from extracellular autoxidation in the presence of (high concentrations of) $\mathrm{H} 1$, probably initiated by superoxide in the medium reacting with catechol, according to $\mathrm{HO}_{2}{ }^{\circ}$ (from 
superoxide) $+\mathrm{QH}_{2} \rightarrow \mathrm{QH}^{\bullet}+\mathrm{H}_{2} \mathrm{O}_{2}$. As a consequence, this would increase the toxicity of $\mathrm{H} 1$ relative to $\mathrm{H} 1-\mathrm{DA}$, as observed. $\mathrm{H} 1$ does not generate significant amounts of $\mathrm{H}_{2} \mathrm{O}_{2}$ and has a high $\mathrm{EC}_{50}$. Whether intracellular or extracellular, it requires much more of this compound to generate the same amount of $\mathrm{H}_{2} \mathrm{O}_{2}$ as $\mathrm{H} 4$. Both diacetylated compounds most likely have an equal chance of entering the cell. However, I have no simple explanation for the higher toxicity of H4-DA than of $\mathrm{H} 4$.

\section{Reaction mechanism and BDE value}

A typical sequence for a catechol undergoing redox reactions and generating superoxide is shown in Scheme 3.1. This scheme shows only the protonated forms of the semiquinone $\left(\mathrm{QH}^{\circ}\right)$ and of superoxide anion (the hydroperoxyl radical $\left.\mathrm{HO}_{2}{ }^{\circ}\right)$; whether the protonated or anionic form is present depends on the $\mathrm{pH}$, but does not affect the general mechanistic argument to follow. (Note that $\mathrm{pK}_{\mathrm{a}}$ 's of semiquinones tend to be rather low at $\mathrm{pH} 4$ to 5 , so the dominant form at $\mathrm{pH} 7.4$ is the anion).

\section{SCHEME 3.1}

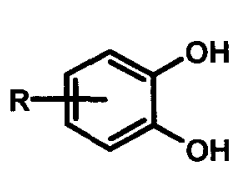

Catechol $\left(\mathrm{QH}_{2}\right)$

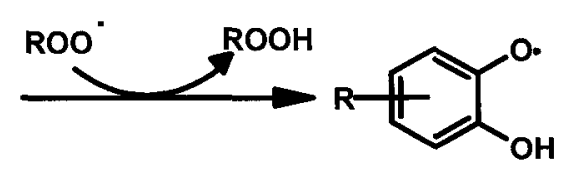

Semiquinone (QH)

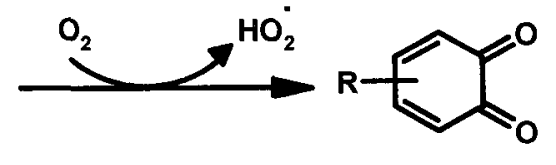

Quinone (Q)

$\mathbf{P} 450$ reductase

NAD(P)H

An attacking radical, e.g. peroxyl ( $\left.\mathrm{ROO}^{\circ}\right)$ provides the initiation step converting $\mathrm{QH}_{2}$ into its semiquinone radical, $\mathrm{QH}^{*}$. Alternatively, $\mathrm{QH}^{*}$ could be produced in a disproportionation reaction between $\mathrm{QH}_{2}$ and $\mathrm{Q}$ (reaction (1)). Note that in the former 
case, $\mathrm{QH}_{2}$ is acting as an antioxidant (deactivates $\mathrm{ROO}^{\circ}$ ) but in the latter disproportionation $\mathrm{QH}_{2}$ becomes a pro-oxidant through generation of its semiquinone radical. This illustrates the complexity of catechol/semiquinone/quinone chemistry, where the rates of competing reactions become relevant to the eventual cytotoxicity. In any case once the semiquinone has formed then redox cycling proceeds as shown. The superoxide anion (hydroperoxyl radical) is generated which disproportionates producing $\mathrm{H}_{2} \mathrm{O}_{2}$ plus molecular oxygen. This is the case with $\mathrm{H} 1, \mathrm{H} 2$ and, to a lesser, extent, $\mathrm{H} 4$.

The effectiveness of $\mathrm{QH}_{2}$ as an antioxidant was strongly correlated with $\mathrm{BDE}_{1}$. Thus we and others have shown that the rate of reaction with the test radical $\mathrm{DPPH}^{\bullet}$ increases (hence a better antioxidant) as $\mathrm{BDE}_{1}$ decreases; i.e. the weaker the bond in $\mathrm{QH}_{2}$ the faster the reaction with the free radical $\operatorname{ROO}^{\bullet}[12,13]$. However, the activity as a prooxidant must depend both on $\mathrm{BDE}_{1}$ (related to rate of generation of $\mathrm{QH}^{\bullet}$ ) and $\mathrm{BDE}_{2}$ (related to rate of production of Q). Thus both BDEs will affect the rate of redox cycling; $\mathrm{BDE}_{1}$ through generation of the semiquinone, and $\mathrm{BDE}_{2}$ through generation of the quinone. Kinetic modeling of this type of complex system has been done by Roginsky and coworkers [53] and for a useful summary of the situation we quote from Pattison et al: "whether DOPA and other catechols behave as antioxidants or pro-oxidants is dependent on the nature of the oxidizing radical, the radical flux, and the reactivity of the resulting semiquinone radical. In general, those catechols that give rise to the most stable (least reactive) semiquinones are the most likely to show antioxidant, rather than prooxidant behavior" [60].

How does this relate to the cytotoxicity of our catechols? From the above discussion it is clear that a low $\mathrm{BDE}_{1}$ is protective, whereas a low $\mathrm{BDE}_{2}$ is destructive to 
the cell. In order to obtain a low $\mathrm{BDE}_{1}$ it is typically needed to load an aromatic ring system with electron donors, e.g. hydroxyl, amino or methoxyl groups or, to a lesser extent, alkyl groups [58]. However, Table 1 shows that $\mathrm{BDE}_{1}$ values that are similar to $\mathrm{BDE}_{2}$ values for the catechols $\mathrm{H} 1, \mathrm{H} 2$ and $\mathrm{H} 4$ described here (e.g. 74 and 73 for $\mathrm{H} 1$ ), indicative of a reactive semiquinone. When both BDEs are approximately equal, this will favor the pro-oxidant case, since the semiquinone (anion) reaction with oxygen is much faster than the catechol reaction with peroxyl radicals. This is the situation for the catechols $\mathrm{H} 1, \mathrm{H} 2$, and $\mathrm{H} 4$, all of which are relatively cytotoxic.

\section{Discussion - proof of redox cycling}

Figure 3.7 shows the proof that the compounds are redox cycling. Differentiated HL-60 cells were incubated with H2-DA, which passed through the cell membrane in 10 to 15 minutes, as shown by the induction period (flat initial slope) in Figure 3.1. There are then two possible mechanisms which can lead to an increase in absorbance with time. The first is stoichiometric, which begins when the catechol $\mathrm{QH}_{2}$ in its neutral form being transported back through the cell membrane into the extracellular fluid, where the indicator is present, and is (partially) converted into its anionic form $\mathrm{QH}^{-}$. This reacts with indicator according to (in abbreviated terminology)

$$
\mathrm{QH}^{-}+\mathrm{III} \rightarrow \mathrm{QH}^{\bullet}+\mathrm{II}
$$

with a rise in absorbance. A second reduction could in principle also occur via the semiquinone radical anion,

$$
\mathrm{Q}^{\bullet-}+\mathrm{III} \rightarrow \mathrm{Q}+\mathrm{II}
$$


In this simple mechanism a stoichiometric factor of two results, i.e. one $\mathrm{QH}_{2}$ can reduce two molecules of III. Further consideration of the disproportionation possibility leads to a maximum stoichiometric factor of 4; i.e. an initial concentration of H2-DA equal to 20 $\mu \mathrm{M}$ could reduce a maximum amount of cytochrome C (III) equivalent to $80 \mu \mathrm{M}$, followed by no further reduction. However, Figure 1 shows that at a concentration of indicator equal to 4 times that of $\mathrm{QH}_{2}$, a constant absorbance is reached by $35 \mathrm{~min}$ showing that all the indicator was used up, i.e. the stoichiometric factor must be greater than 4. This result is explained as follows: First, an initiating free radical is generated, probably by disproportionation as in reaction (1), since a small amount of Q is always present along with $\mathrm{QH}_{2}$. A redox cycle now begins to produce superoxide according to reaction (2) and (3), followed by one-electron reduction of $\mathrm{Q}$ back to $\mathrm{Q}^{\bullet-}$ to continue the chain, and superoxide ion is exported outside the cell (possibly via its conjugate acid, $\mathrm{HO}_{2}{ }^{\circ}$ ). This results in a stoichiometric factor which depends on the redox cycle chain length. Thus Figure 3.7 shows unambiguous proof that a redox cycle is occurring for the catechol $\mathrm{H} 2$ inside the HL-60 cells.

Another way to prove the intracellular redox cycling vs. extracellular oxidation mechanism is to measure the extent of intracellular oxidation products using a dichlorofluorescein indicator. The oxidation of the nonfluorescent 2'7'dichlorodihydrofluorescein diacetate $\left(\mathrm{H}_{2} \mathrm{DCF}-\mathrm{DA}\right)$ to the highly fluorescent 2'7'dichlorofluorescein (DCF) is used to detect the generation of (ROS; previously defined).

First, PC12-AC cells were incubated in HBSS solution with $40 \mu \mathrm{M}$ DCF-DA for $1.5 \mathrm{~h}$ to load the cells. Then H2-DA was incubated with the cells for an additional $2 \mathrm{~h}$. If redox cycling is occurring it should oxidize the DCF and generate a fluorescence signal. 
An increasing in fluorescence was observed with increasing of H2-DA concentration. The compound undergoes redox cycling inside the cells, and ROS are produced which oxidize the dye.

\section{Effect of ascorbate on toxicity correlates with BDE value}

As discussed above, ascorbate is protective (decreases cytotoxicity) in the case of $\mathrm{H} 1$ and $\mathrm{H} 2$, but increases the cytotoxicity of $\mathrm{H} 4$. How can be explained the difference? Assume for simplicity that ascorbate acts by $\mathrm{H}$-atom transfer rather than electron transfer. Reaction (5) shows that ascorbate can increase the rate of the redox cycle by one-electron reduction of $Q$ in parallel with the enzymatic reduction; this must increase the cytotoxicity. On the other hand, ascorbate can reduce the semiquinone according to reaction 8 .

Comparing reactions (5) and (8) it is clear that the rate of reduction of the closedshell quinone $\mathrm{Q}$ must be much slower than the reduction of the open-shell radical $\mathrm{QH}^{\circ}$. This statement is consistent with known data from Roginsky and coworkers [16,53], where the rate constant for the quinone reduction is slower by several orders of magnitude than that of semiquinone reduction. Therefore I focused on the first step, the conversion between $\mathrm{QH}_{2}$ (non-toxic) and $\mathrm{QH}^{\bullet}$ (toxic). Now consider the comparative gas-phase BDE values, which I use as a guide to reduction potentials in aqueous solution [49]. The BDE for $\mathrm{AscH}^{-} \rightarrow \mathrm{Asc}^{--}+\mathrm{H}$ is $68.5 \mathrm{kcal} \mathrm{mol}^{-1}$. Therefore $\mathrm{AscH}^{-}$can reduce anything whose radical has a $\mathrm{BDE}$ above this, e.g. $\mathrm{QH}^{\bullet}$ for $\mathrm{H} 1$ and $\mathrm{H} 2$, with $\mathrm{BDE}_{1}$ of 73 and $69 \mathrm{kcal} \mathrm{mol}^{-1}$, respectively. This reaction regenerates the catechol and is protective. On the other hand, for $\mathrm{H} 4$, whose $\mathrm{BDE}_{1}$ lies below that of ascorbate, its semiquinone 
radical is not reduced by ascorbate anion (no protection from ascorbate). But why should a very weak $\mathrm{QH}_{2}$ bond $\left(<68.5 \mathrm{kcal} \mathrm{mol}^{-1}\right)$ increase the toxicity of added ascorbate?

One mechanism which provides an answer is that the catechol can then react with ascorbate radical anion according to the reverse of reaction 8 , i.e.

$$
\mathrm{QH}_{2}+\mathrm{Asc}^{\bullet-} \rightarrow \mathrm{QH}^{\bullet}+\mathrm{AscH}^{-}
$$

These two cases are summarized in Scheme 3.2, below. Case 1 is protective, converting semiquinone back to catechol. Case 2 should increase the toxicity, since now the semiquinone is competing with ascorbate radical anion disproportionation (protective, regenerates ascorbate anion) to create more semiquinone (destructive). Thus ascorbate radical anion, which is normally non-toxic, acts as a pro-oxidant through conversion of the catechol into the semiquinone. Creation of a catechol with a $\mathrm{BDE}_{1}$ even lower than H4 could easily be accomplished, and these low BDE compounds should show strongly increased cytotoxicity in the presence of added ascorbate anion. This binary effect could be beneficial under the right circumstances, such as the targeted delivery of such a compound to a cancer cell [62], combined with ascorbate supplementation. 


\section{SCHEME 3.2}

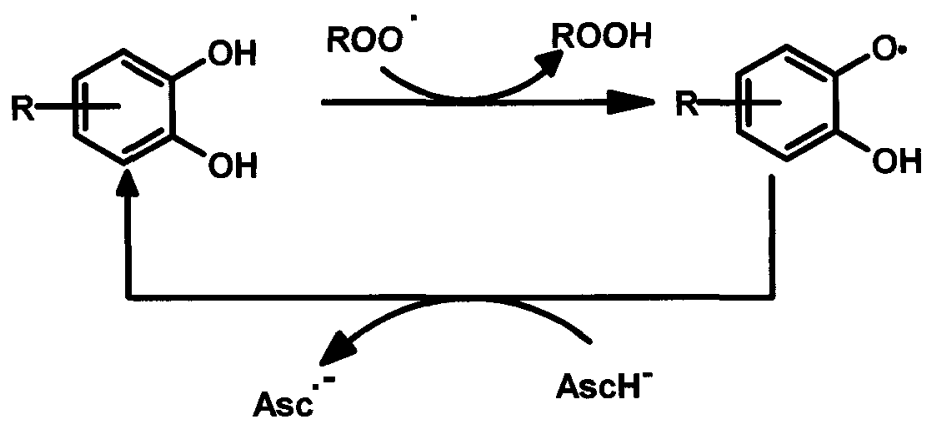

Case 1. BDE $>68.5 \mathrm{kcal} / \mathrm{mol}$, ascorbate anion is protective

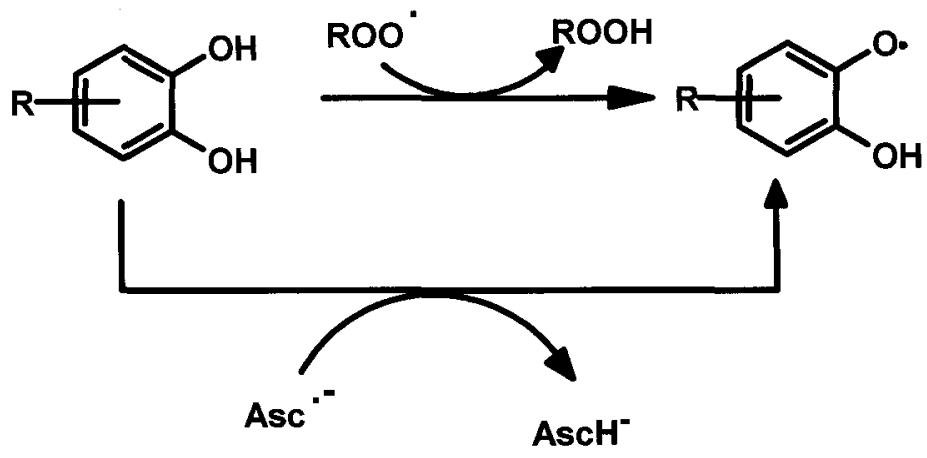

Case 2. BDE $<68.5 \mathrm{kcal} / \mathrm{mol}$, ascorbate anion is destructive

\section{Cytotoxicity correlates with $\mathrm{H}_{2} \mathrm{O}_{2}$ response curves}

As shown in Figure 3.6a, for the pure redox cycling case of $\mathrm{H} 1$ the $\mathrm{H}_{2} \mathrm{O}_{2}$ generation is large and increases almost linearly with concentration of substrate. Ascorbate begins to decrease the production of $\mathrm{H}_{2} \mathrm{O}_{2}$ at concentrations of $\mathrm{H} 1$ greater than ca. $50 \mu \mathrm{M}$. This is perfectly mirrored in the cytotoxicity curves for $\mathrm{H} 1$ and $\mathrm{H} 1+$ ascorbate (Figure 3.2a): Ascorbate becomes protective to $\mathrm{H} 1$ at concentrations greater than ca. $50 \mu \mathrm{M}$. For H2-DA (Figure 3.6b) there is little effect due to ascorbate and it does not occur until relatively high concentration, so this case is not clear. On the other hand, for $\mathrm{H} 4$ at low concentrations, ascorbate increases peroxide production (Figure 3.6c) 
and simultaneously increases cytotoxicity (Figure 3.3a). Note also that overall more peroxide is produced for H4-DA than for $\mathrm{H} 4$, consistent with its greater cytotoxicity.

In general, for the pure redox cycling of $\mathrm{H} 1$ and $\mathrm{H} 2$, it appears that the effect of added ascorbate can be determined by examining the amount of $\mathrm{H}_{2} \mathrm{O}_{2}$ produced. Since it is the redox cycling which is causing toxicity, more $\mathrm{H}_{2} \mathrm{O}_{2}$ produced means higher cytotoxicity. Conversely, when a diacetate form (H1-DA) leads to reduced peroxide production, this also leads to lower cytotoxicity.

H4 is capable of both redox cycling and thiol depletion. Nevertheless the peroxide response curves give important indicators of cytotoxicity: when peroxide concentrations increase as ascorbate is added, so does cytotoxicity. Thus the more unusual case of ascorbate ion potentiating cytotoxicity can also be predicted from examination of the $\mathrm{H}_{2} \mathrm{O}_{2}$ response curves.

\section{Glutathione response curves}

The $24 \mathrm{~h}$ GSH response to H1-DA, H2-DA and H4 all show GSH increasing with concentration of substrate (Figure 3.8). Evidently the cell must up-regulate glutathione synthesis in response to catechol treatment on the $24 \mathrm{~h}$ time scale of the experiment. In other work [63] it has been shown that this up-regulation does in fact occur in a number of other systems causing oxidative stress which are related to catechols. This phenomenon was discussed in a systematic way by Han et al. [63], who described an increase in GSH in response to catechols, hydroquinones, L-dopa, dopamine and apomorphine. These authors believed that a compound must autoxidize to show this GSH response, e.g. by reaction of semiquinone plus molecular oxygen to produce 
superoxide ion. This caused an initial rise in GSSG, which triggered the up-regulation of total glutathione synthesis. Earlier work on quinone-induced oxidative stress showed upregulation of $\gamma$-GCS led to elevated glutathione levels [64]. The same effect was reported later by Ishige et al. [65] and Myhrstad et al. [66] for flavonoids; the latter work explicitly monitored the (rapid) up-regulation of $\gamma$-glutamylcysteine synthetase, which preceded the rise in total glutathione levels. Another study using endothelial cells showed that $100 \mu \mathrm{M}$ hydrogen peroxide was sufficient to cause a doubling in total glutathione levels [67].

The time sequence of measurement of GSH is important, and in our experiments the period of incubation is $24 \mathrm{~h}$. This observation period plays a role because, for example, Dabrosin and Ollinger [68] showed that exposure of hepatocytes to estradiol caused a $25 \%$ decrease in GSH at $4 \mathrm{~h}$, whereas the GSH levels at $20 \mathrm{~h}$ had nearly doubled.

Considering each compound separately (Figure 3.8), the redox cycler H1-DA shows a steady increase over its range, until the error bars become large near its $\mathrm{EC}_{50}$ of ca. 50 $\mu \mathrm{M}$, as determined using the $10 \mathrm{~cm}$ dishes (Note: $\mathrm{EC}_{50}$ 's are lower by a factor of two compared to the MTT assay, because the concentration of cells $/ \mathrm{cm}^{2}$ in the GSH assay is much lower than in the MTT assay, which uses microplate wells). The more toxic redox cycler H2-DA shows a very dramatic increase and reaches a value of nearly 4.0 relative to control; the cells are showing an amazingly high up-regulation of GSH in response to the oxidative stress as the $\mathrm{EC}_{50}$ is approached.

Compound H4-DA presents an interesting choice between possible thiol depletion and concurrent redox cycling. GSH for H4-DA is evidently still strongly up-regulated (factor of at least three) rather than depleted, in spite of the smaller amount of peroxide generated (Figure 3.7c). Thus based on the assays we chose it is difficult to give a simple 
interpretation of the cause of cytotoxicity for these catechols, since the cells are producing $\mathrm{H}_{2} \mathrm{O}_{2}$ from redox cycling, but attempting to compensate for the increased oxidative stress by the up-regulation of GSH production.

What it was found remarkable is that all three of these compounds, although reacting by different mechanisms, cause an observed $24 \mathrm{~h}$ increase in GSH concentration. Clearly the cell is trying to react to a changing redox environment so as to minimize the toxicity.

Literature cited above has shown this to occur in a number of cells and for a number of compounds, and it is speculated that this is a response to oxidative stress. It would be of considerable interest to define the generality and magnitude of this response as a function of cell line and molecular characteristics of the oxidative stressor.

\section{Cytoprotection of H2-DA compared with EGCG against oxidative stress induced by menadione or AAPH}

In order to test the catechols for their cytoprotection capacity against oxidative stress, using a range of concentrations in which the catechols are non-toxic, I have chosen menadione as a stressor. The cells are first treated with the compounds and then incubated with menadione. Menadione induces cytotoxicity in many cells $[69,70]$. There are two mechanisms underlying this toxicity: a) menadione produces oxidative stress via redox cycling: menadione is converted to semiquinone radicals by microsomal or mitochondrial enzymes and the radicals generated react with molecular oxygen, thus releasing superoxide anions and subsequent redox cycling and b) the reaction of menadione with soluble thiols (like GSH) or protein thiols results in formation of 
quinone-glutathione conjugates or quinone-protein adducts, respectively, resulting in depletion of thiols and a change in the intracellular redox status.

The antioxidant activity and hence cytoprotection is related to $\mathrm{BDE}_{1}$. A lower $\mathrm{BDE}_{1}$ means a more active antioxidant and a higher ability to scavenge ROS. In previous chapter it was discussed the antioxidant activity of catechols and EGCG. It was found that the most active in scavenging superoxide radicals is H2-DA. Therefore, I tested H2DA and also its combination with ascorbate (lower the toxicity of H2-DA) and EGCG for cytoprotective activity against menadione. Based on the $\mathrm{BDE}_{1}\left(\mathrm{BDE}_{1}\right.$ of $\mathrm{H} 2-\mathrm{DA}=69$ $\mathrm{kcal} \mathrm{mol}^{-1}<\mathrm{BDE}_{1}$ of EGCG $=71 \mathrm{kcal} \mathrm{mol}^{-1}$ ) it was predicted that $\mathrm{H} 2-\mathrm{DA}$ would be the most protective. For the same concentration tested of $10 \mu \mathrm{M}$ of the compounds, I obtained a higher protection of H2-DA than EGCG. A synergistic protective effect was seen for a combination of $10 \mu \mathrm{M} \mathrm{H} 2-\mathrm{DA}$ and $50 \mu \mathrm{M}$ ascorbate. I suggest that the protective action of catechols against menadione is associated with their superoxide scavenging activity.

Since menadione acts by a wide variety of pharmacological actions that may all contribute to cell death I decided to test the compounds against AAPH. The toxicity of AAPH is due to the peroxyl radical formation.

As shown in Figures 3.17-3.18, the cytoprotection area (CPA) of a compound was defined as an integral of the region where cell viability exceeds that of the cells remaining after AAPH treatment (40\% viability) is related both to its protective effect and its toxicity envelope. Basing the protective effect on $\mathrm{BDE}_{1}$ alone, it was predicted an order of protection which is H2-DA > EGCG. However, the CPA gives the order EGCG $(\mathrm{CPA}=17,300)>\mathrm{H} 2-\mathrm{DA}(\mathrm{CPA}=828 \pm 120)$ so $\mathrm{BDE}_{1}$ is not a useful descriptor of 
cytoprotection. Clearly the reason for this is that the cytotoxicity, which provides the upper envelope for the CPA, is far more important in determining the CPA. EGCG is 20 times more protective than H2-DA. The protection of H2-DA, coupled with its high toxicity (its $\mathrm{EC}_{50}$ is only $32 \mu \mathrm{M}$ ), suggests that this is a poor compound (low $\mathrm{EC}_{50}$, narrow protective range, low CPA). Based on this, the goal is to design compounds with a low inherent toxicity and a wide protective range.

\subsection{CONCLUSION}

Based on the above, for any catecholic antioxidant capable of first and second dissociations, a low $\mathrm{BDE}_{1}$ will favor the antioxidant character, but a low $\mathrm{BDE}_{2}$ will cause pro-oxidant behavior. This is due to the tendency of the semiquinone to have a low $\mathrm{pK}_{\mathrm{a}}$ value and the rapid rate of reaction of its anion $\mathrm{Q}^{\bullet-}$ with oxygen to generate superoxide. Thus, making semiquinone formation easy but quinone formation more difficult will be a desirable design. In this way we will lower the toxicity and increase the protection capacity of the antioxidants. In the next chapter it is designed a new class of novel synthetic antioxidants: substituted naphthalenediols. I test them for cytotoxicity and protective effects against oxidative stress in adrenal and primary cortical neuronal cells.

\subsection{REFERENCES}

1. Brunmark, A., and Cadenas, E. (1989) Redox and addition chemistry of quinoid compounds and its biological implications. Free Rad. Biol. Med. 7, 435-477.

2. O'Brien, P.J. (1991) Molecular mechanisms of quinone toxicity. Chem.-Biol. Int. 80, $1-31$. 
3. Decker, E. A. (1997) Phenolics: Prooxidants or antioxidants? Nutr. Rev. 55, 396-398.

4. Weisburger, J. H., and Chung, F-L. (2002), Mechanism of the chronic disease causation by nutritional factors and tobacco products and their prevention by tea polyphenols. Food Chem. Toxicol. 40, 1145-1155.

5. Galati, G., Moridani, M. Y., Chan, T. S., and O'Brien, P. J. (2001) Peroxidative metabolism of apigenin and naringenin versus luteolin and quercetin: glutathion oxidation and conjugation. Free Radic. Biol. Med. 30, 370-382.

6. Jovanovic, S. V., Steenken, S., Tosic, M., Marjanovic, B., and Simic, M. G. (1994) Flavonoids as antioxidants. J. Am. Chem. Soc. 116, 4846-4851.

7. Bors, W., Heller, W., Michel, C., and Saran, M. (1990) Flavonoids as antioxidants: determination of radical-scavenging efficiencies. Methods Enzymol. 186, 343-355.

8. Bors, W., Michel, C., and Saran, M. (1994) Flavonoids as antioxidants: Rate constats for reactions with oxygen radicals. Methods Enzymol. 234, 420-429.

9. Qiuyin, C., Rahn, R.O., and Ruiwen, Z. (1997) Dietary flavonoids ,quercetin, luteolin and genistein, reduce oxidative DNA damageand lipid peroxidation and quench free radicals. Cancer Lett.119, 99-107.

10. Afanasev, I. B., Dorozhko, A. I., Brodskii, A. V., Kontyuk, V. A., and Potapovitch, A. I. (1989) Chelating and free radical scavenging mechanism of inhibitory action of rutin and quercetin in lipid peroxidation. Biochem. Pharmacol. 38, 1763-1768.

11. Morel, I., Lescoat, G., Cogrel, P., Sergent, O., and Pasdeloup, N. (1993) Antioxidant and iron-chelating activities of the flavonoids catechin, quercetin and diosmetin on ironloaded rat hepatocyte cultures. Biochem. Pharmacol. 45, 13-19. 
12. Foti, M. C., Johnson, E. R., Vinqvist, M. R., Wright, J. S., Barclay, L. R. C., and Ingold, K. U. (2002) Naphthalene diols: a new class of antioxidants. Intramolecular hydrogen bonding in catechols, naphthalene diols and their aryloxyl radicals. J. Org. Chem. 67, 5190-5196.

13. Hussain, H. H., Babic, G., Durst, T., Wright, J. S., Flueraru, M., Chichirau, A., and Chepelev, L. L. (2003) Development of novel antioxidants: design, synthesis and reactivity. J. Org. Chem. 68, 7023-7032.

14. Monks, T. .J., Hanzlik, R. P., Cohen, G. M., Ross, D., and Graham, D. G. (1992) Contemporary issues in toxicology: Quinone chemistry and toxicity. Toxicol. Appl. Pharmacol. 112, 2-16.

15. Fan, P. W., Zhang, F., and Bolton, J. L. (2000) 4-hydroxylated metabolites of antiestrogens tamoxifen and toremifene are metabolized to unusually stable quinone methides. Chem., Res., Toxicol.13, 45-52.

16. Roginsky, V. A., Barsukova, T. K., and Stegmann, H. B. (1999) Kinetics of redox interaction between substituted quinones and ascorbate under aerobic conditions. Chem. Biol. Int. 121, 177-197.

17. Halliwell, B., and Gutteridge, J. M. C. (1999) Free Radicals in Biology and Medicine, Oxford University Press: Oxford.

18. Watanabe, N., and Forman, H. J. (2003) Autoxidation of extracellular hydroquinones is a causative event for the cytotoxicity of menadione and DMNin A539-S cells. Arch. Biochem. Biophys. 411, 135-157. 
19. Morita, K., Arimochi, H., and Ohnishi, Y. (2003) In vitro cytotoxicity of 4methylcatechol in murine tumor cells: induction of apoptotic cell death by extracellular pro-oxidant action. J. Pharmacol. Exp. Ther. 306, 317-323.

20. Munday, R. (2000) Autoxidation of naphthohydroquinones: effects of $\mathrm{pH}$, naphthoquinones and superoxide dismutase. Free Rad. Biol. Med. 32, 245-253

21. Munday, R. (2004) Activation and detoxification of naphthoquinones by NAD(P)H: quinone oxidoreductase. Methods Enzymol. 382, 364-380.

22. Graham, D. G. (1978) Oxidative pathways for catecholamines in the genesis of neuromelanin and cytotoxic quinones. Mol. Pharmacol. 13, 633-633.

23. Bindoli, A., Rogobello, M. P., and Deeble, D. J. (1992) Biochemical and toxicological properties of the oxidation products of catecholamines. Free Rad. Biol. Med. 13, 391-305.

24. Chen, Q., and Ames, B. N. (1994) Senescence-like growth arrest induced by hydrogen peroxide in human diploid fibroblast F65 cells. Proc. Natl. Acad. Sci USA 91, 4130-4134.

25. DeHaan, J. B., Bladier, C., Mehrnoush, L.-M., Taylor, J., Hutchinson, P., Crack, P. J., Hertzog, P., and Kola, I. (2004) Fibroblasts derived from Gpx1 knockout mice display senescent-like features and susceptible to $\mathrm{H}_{2} \mathrm{O}_{2}$-mediated cell death. Free Rad. Biol. Med. 36, 53-64.

26. Van der Pols, J. C. (1999) A possible role for vitamin C in age-related cataract. Proc. Nutri. Soc. 58, 295-301.

27. Van Muiswinkel, F. L., Riemers, G. M., Peters, G. J., LaFleur, M. V. M., Siegel, D., Jongenelen, C. A. M., and Drukarch, B. (2000) L-Dopa stimulates expression of the 
antioxidant enzyme NAD(P)H:Quinone oxidoreductase (NQO) in cultured astorglial cells. Free Rad. Biol. Med. 29, 332-353.

28. May, J. M., Qu, Z-C., and Li, X. (2003) Ascorbic acid blunts oxidant stress due to menadione in endothelial cells. Arch. Biochem. Biophys. 311, 136-133.

29. Samuni, A. M., Chuang, E. Y., Krisha, M. C., Stein, W., DeGraff, W., Russo, A., and Mitchell, J. B. (2003) Semiquinone radical intermediate in catecholic estrogen-mediated cytotoxicity and mutagenesis: Chemoprevention strategies with antioxidants. Proc. Nat. Acad. Sci. 100, 5390-5395.

30. Carr, A., and Frei, B. (1999) Does vitamin C act as a pro-oxidant under physiological conditions? FASEB Journal 13, 1007-1023.

31. Ashidate, K., Kawamura, M., Hisako, T., Miyazaki, S., Hayashi, H., Teramoto, T.,and Hirata, Y. (2003) Ascorbic acid augments cytotoxicity induced by oxidized lowdensity lipoprotein. J. Atheroscle. Thombosis 10, 7-12.

32. Pethig, R., Gascoyne, P. R. C., MacLaughlin, J. A., and Szent-Gyorgi, A. (1983) Ascorbate-quinone interactions: Electrochemical, free radical and cytotoxic properties. Proc. Natl. Acad. Sci. USA. 80, 129-132.

33. Burstein D.E., and Greene L.A. (1982) Nerve growth factor has both mitogenic and antimitogenic activity. Dev. Biol. 93, 377-382.

34. Greene, L. A., Aletta J. .M., Rukenstein A., and Green S.H. (1987) PC12 pheochromocytoma cells: culture, nerve growth factor treatment, and experimental exploitation. Methods Enzymol. 137, 207-216. 
35. Denizot, F., and Lang, R. (1986) Rapid colorimetric assay for cell growth and survival: modification to the tetrazolium dye procedure giving improved sensitivity and reliability. J. Immunol. Methods 89, 271-277.

36. Dixon, D. N., Loxley, R. A., Barron, A., Cleary, S., and Phillips, J. K. (2005) Comparative studies of PC12 and mouse pheochromocytoma-derived rodent cell lines as models for the study of neuroendocrine systems. In vitro Cell Dev. Biol. - Animal 41, 197-206.

37. Teng, K. K., Georgieff, I. S., Aletta, J. M., Nune, J., Shelanski, M. L., and Greene, L. A. (1993) Characterization of a PC12 cell sub-clone (PC12-C41) with enhaced neurite outgrowth capacity: implications for a modulatory role of high molecular weight tau in neuritogenesis. J. Cell Sci. 106, 611-626.

38. Collins, S.J., Gallo, R. C., and Gallagher, R. E. (1977) Continuous growth and differentiation of human myeloid leukaemic cells in suspension culture. Nature (London) $270,347-349$.

39. Collins, S.J., Ruscetti, F. W., Gallagher, R. E., and Gallo, R. C. (1978) Terminal differentiation of human promyelocytic leukemia cells induced by dimethyl sulfoxide and other polar compounds. Proc. Natl. Acad. Sci. USA 75, 2458-2462.

40. Mossman, T. (1983) Rapid colorimetric assay for cellular growth and survival; application to proliferation and cytotoxicity assays. J. Immunol. Methods, 65, 55-63.

41. Vistica, D.T., Skehan, P., Scudiero, D., Monks, A., Pittman, A., and Boyd, M. R. (1991) Tetrazolium-based assays for cellular viability: a critical examination of selected parameters affecting formazan production. Cancer Res. 51, 2515-2520. 
42. Wang, H., and Joseph, J.A. (1999) Quantifying cellular oxidative stress by dichlorofluorescein assay using microplate reader. Free Rad. Biol. Med. 27, 612-616.

43. Newburger, P E., Chovaniec, M. E., Greenberger, J. S., and Cohen, H. J. (1979) Functional changes in human leukemic cell line HL-60. A model for myeloid differentiation. J. Cell Biol. 82, 315-22.

44. Lee, S. K., Mbwambo, Z. H., Chung, H., Luyengi, L, Gamez, E. J. C., Mehta, R. G., Kinghorn, A., Douglas, and Pezzuto, J. M. (1998) Evaluation of the antioxidant potential of natural products. Comb. Chem. and High Throughput Screen. 1, 35-36.

45. Tietze, F. (1969) Enzymic method for quantitative determination of nanogram amounts of total and oxidized glutathione: applications to mammalian blood and other tissues. Anal. Biochem. 27, 502-522.

46. Bradford, M. M. (1976) A rapid and sensitive method for the quantitation of microgram quantities of protein utilizing the principle of protein-dye binding. Anal. Biochem. 72, 238-253.

47. Wolff, S. P. (1993) Ferrous ion oxidation in the presence of ferric ion indicator xylenol orange for measurement of hydroperoxides. Methods Enzymol. 233, 182-189.

48. Terao, K., and Niki, E. (1986) Damage to biological tissues induced by radical initiator 2,2'-azobis(2-amidinopropane) dihydrochloride and its inhibition by chainbreaking antioxidants. Free Radic. Biol. Med. 2, 193-201.

49. DiLabio, G. A., Pratt, D. A., LoFaro, A. D., and Wright, J. S. (1999) Theoretical Study of X-H Bond Energetics $(\mathrm{X}=\mathrm{C}, \mathrm{N}, \mathrm{O}, \mathrm{S})$ : Application to Substituent Effects, Gas Phase Acidities and Redox Potentials. J. Phys. Chem. A 103, 1653-1661.

50. Gaussian 98, Revision A.7, Gaussian, Inc., Pittsburgh PA, 1998. 
51. Villar (J. Computational Chem., 6, 681 (1991) Int. J. Quantum Chem., 33.

52. Siegel, S. M., and Siegel, B. Z. (1958) Autoxidation of pyrogallol: general characteristics and inhibition by catalase. Nature (London) 181, 1153-1154.

53. Roginsky, V. A.,;Michel, C., and Bors, W. (2000) Reactivity of semiquinones with ascorbate and the ascorbate radical as studied by pulse radiolysis. Arch. Biochem. Biophys. 393, 73-80.

54. Lee, S. K., Mbwambo, Z. H., Chung, H., Luyengi, L., Gamez, E. J. C., Mehta, R., G., Kinghorn, A. D., and Pezzuto, J. M. (1998) Evaluation of the antioxidant potential of natural products. Comb. Chem. High Throughput Screen. 1, 35-46.

55. Long, L. H., and Halliwell, B. (2001) Oxidation and generation of hydrogen peroxide by thiol compounds in commonly used cell culture media. Biochem. Biophys. Res. Commun. 286, 991-994.

56. Gant, T. W., Ramakrishna, D. N. R., and Mason, R. P. (1988) Redox cycling ann sulphydryl arylation: Their relative importance in the mechanism of quinone cytotoxicity to isolated hepatocytes. Chem.-Biol. Interactions $65,157-173$.

57. Lam, L. K. T., Garg, P. K., Swanson, S. M., and Pezzuto, J. M. (1988) Evaluation of the cytotoxic potential of catechols and quinones structurally related to butylated hydroxyanisole. J. Pharm. Sci. 77, 393-395.

58. Moridani, M. Y., Siraki, A., and O’Brien, P. J. (2003) Quantitative structure toxicity relationships for phenols in isolated rat hepatocytes. Chemico Biol. Int. 135, 213-223.

59. Miller, J. W., Selhub, J., and Joseph, J. A. (1996) Oxidative damage caused by free radicals produced during catecholamine autoxidation: protective effects of $O$ methylation and melatonin. Free Rad. Biol. Med. 21, 231-239. 
60. Pattison, D. K., Dean, R. T., and Davies, M. J. (2002) Oxidation of DNA, proteins and lipids by DOPA, protein-bound DOPA, and related catechol(amine)s. Toxicology 177, 23-37.

61. Wright, J. S., Johnson, E. R., and DiLabio, G. A. (2001) Predicting the activity of phenolic antioxidants. J. Am. Chem. Soc. 12, 1173-1183.

62. Cadenas, E., and Packer L. (1996) Handbook of antioxidants, New York : M. Dekker 63. Han, S.-K., Mytilineou, C., and Cohen, G. (1996) L-DOPA up-regulates glutathione and protects mesencephalic cultures against oxidative stress. J. Neurochem. 66, 501-510. 64. Shi, M. M., Kugelman, A., Iwamoto, T., Tian, L., and Forman, H. J. (1994) Quinoneinduced oxidative stress elevates glutathione and induces $\gamma$-glutamylcysteine synthetase activity in rat lung epithelial L2 cells. J. Biol. Chem. 269, 26512-26517.

65. Ishige, K., Schubert, D., and Sagara, Y. (2001) Flavonoids protect neuronal cells from oxidative stress by three distinct mechanisms. Free Rad. Biol. Med. 30, 333-336.

66. Myhrstad, M. C. W., Carlsen, L. N., Blomhoff, R., and Moskaug, J. O. (2002) Flavonoids increase the intracellular glutathione level by transactivation of the $\gamma$ glutamylcysteine synthetase catalytical subunit promoter. Free Rad. Biol. Med. 32, 386393.

67. Day, R. M., Suzuki, Y. J., Lum, J. M., White, A. C., and Fanburg, B. L. (2002) Bleomycin up-regulates expression of $\gamma$-glutamylcysteine synthetase in pulmonary artery endothelial cells. Am. J. Physiol. - Lung Cell Mol. Physiol. 282, L1349-L1357.

68. Dabrosin, C., and Ollinger, K. (2003) Variability of Glutathione during the menstrual cycle_-due to estrogen effects on hepatocytes? Free Rad. Biol. Med.36, 145-151. 
69. Thor, H., Smith, M. T., Hartzell, P., Bellomo, G., Jewell, S. A., and Orrenius, S. (1982) The metabolism of menadione (2-methyl-1,4-naphthoquinone) by isolated hepatocytes. J. Biol. Chem. 257, 12419-12425.

70. D’Arcy, D. M., Rodgers, A., Cohen, G. M. (1987) Mechanism of toxicity of 2- and 5-hydroxy-1,4-naphthoquinone; absence of a role for redox cycling in the toxicity of 2hydroxy-1,4-naphthoquinone to isolated hepatocytes. J. Appl. Toxicol. 7, 123-129. 


\title{
Chapter 4
}

\section{Cytotoxicity and cytoprotective activity of}

\section{naphthalenediols depends on their tendency to form}

\author{
naphthoquinone
}




\subsection{INTRODUCTION}

In previous chapters it was discussed the concept of a "design window" for creation of an antioxidant with anti-radical activity superior to vitamin $\mathrm{E}$ [1-2]. Molecules which fit into this "window" had bond dissociation enthalpies (BDEs) in the range $69-75 \mathrm{kcal} / \mathrm{mol}$. Using this design window, several catechols were synthesized and tested in organic solvent against the standard free radical $\mathrm{DPPH}^{\bullet}$ and also in cell culture using cytochrome $\mathrm{C}$ assay. The correlations between calculated $\mathrm{BDE}$ values and $\log \mathrm{k}$, the second-order rate constant, and between $\mathrm{IC}_{50}$ and $\mathrm{BDE}$ respectively were excellent [1]. Three catechols and the well-known compound epigallocatechin gallate (EGCG) were then tested in cell culture using PC12-AC cells. The catechols had high cytotoxicity, with EGCG being much less toxic [3]. They also showed a cytoprotective effect against menadione or (2,2'-azobis (2-amidinopropane) hydrochloride (AAPH), but in a very narrow range. Because of their cytotoxicity, the catechols appeared to be a questionable starting point for further antioxidant development. Thus, we started to examine compounds that had a low $\mathrm{BDE}_{1}$ that will favor the antioxidant character and a high $\mathrm{BDE}_{2}$ to make more difficult the formation of quinone (redox cycling and Michael addition). Therefore, we designed and tested a new class of synthetic antioxidants, the naphthalenediols which satisfy both criteria.

Naphthoquinones occur naturally in the environment and in biological systems as metabolites of naphthalene, as components involved in mitochondrial respiration, as foodstuffs, as environmental pollutants, and as anti-cancer drugs [4-6]. The cytotoxicity of substituted naphthoquinones was discussed by Miller et al. [7], who examined the series 1,4-NQ, 2-Me-1,4-NQ and 2,3-diMe-1,4-NQ, where Me $=$ methyl and $\mathrm{NQ}=$ 
naphthoquinone, and found that the order of toxicity was 1,4-NQ $\sim 2-\mathrm{Me}-1,4-\mathrm{NQ}>>2,3-$ diMe-1,4-NQ. This order correlated both with the amount of thiol alkylation and its subsequent depletion, and with the amount of redox cycling, so it was not clear which mode caused more toxicity. Later work [8] showed that thiol alkylation via Michael addition is the more important toxic mechanism. Thus, the pure redox cycler 2,3dimethoxy-1,4-NQ is relatively nontoxic [8] compared to menadione (2-methyl-1,4-NQ), consistent with the fact that the former does not undergo Michael addition whereas the latter does. Other factors considered relevant to cytotoxicity include lipophilicity and the $\mathrm{pK}_{\mathrm{a}}$ of the naphthalenediol form [5,9-10].

Naphthoquinones (NQ) can be formed by autoxidation of naphthalenediols (ND, also called naphthohydroquinones). This oxidation was studied with respect to reactivity of the estrogen steroid hormone equilenin [11-12]. Equilenin is metabolized to either 2hydroxyequilenin or 4-hydroxyequilenin. The latter diol autoxidizes non-enzymatically to the corresponding naphthoquinone. However, the 2-hydroxyequilenin never oxidizes to the corresponding 2,3-naphthoquinone, thus the two naphthoquinones have fundamentally different stability. As early as 1974, Arnold and coworkers [13] and later Scott et al. [14] carried out calculations on ground-state properties of benzo-, naphthoand anthraquinones. They studied the 1,2-, 1,4-, 1,5- 1,7-, 2,3- and 2,6-NQs and showed that the 1,2- and 1,4-forms were particularly stable due to preservation of a single (fully aromatic) benzene ring adjacent to the quinone ring. The others were much less stable due to the energy penalty associated with loss of aromaticity in the adjacent benzene ring (as with 2,3-naphthoquinone) or when in a completely quinonoid structure (as with 2,6naphthoquinone) [11]. 
In addition to being cytotoxic, naphthalenediols and the related catechols can also be cytoprotective, i.e. by acting as antioxidants. Catechols act as an antioxidant by donating its first hydrogen to a radical such as $\mathrm{ROO}^{\bullet}$, forming the semiquinone $\left(\mathrm{QH}_{2} \rightarrow\right.$ $\mathrm{QH}^{\bullet}$ ) and $\mathrm{ROOH}$, thus breaking the chain reaction of lipid peroxidation [2]. Showing purely antioxidant behavior then requires that cellular reducing equivalents, e.g. ascorbate or glutathione, to reduce the semiquinone back to the diol form. The importance of added antioxidants in reducing toxicity has been shown in many publications, such as in reducing cytotoxicity of catecholic estrogen [15].

If the semiquinone is not reduced, it can act as a pro-oxidant by donating a second hydrogen (or electron, since the semiquinone has a low $\mathrm{pK}_{\mathrm{a}}$ ), giving $\mathrm{Q}^{\bullet-}$, which donates an electron to oxygen to form superoxide and the quinone Q. Toxicity generally arises, as discussed above, from the $\mathrm{Q}$ alkylating glutathione or protein thiols via Michael addition or via enzymatic redox cycling between $Q^{\bullet-} \rightarrow Q$, and back [4]. Other mechanisms include extracellular autoxidation [16-17] or some combination of intra/extracellular transport and autoxidation [18].

In this chapter, I tested the hypothesis that naphthalenediols, capable of forming the corresponding naphthoquinone, are relatively cytotoxic, whereas those which cannot are relatively nontoxic. Using PC12-AC cells [19], all compounds were compared for cytotoxicity, including the polyphenolic antioxidant EGCG as a reference compound. Each compound was tested for protective effects against the aqueous-phase peroxyl radical generator AAPH. Toxicity and protective data were combined to create a measure of cytoprotective efficacy for each compound. Theoretical calculations of BDE were utilized to predict the toxic or protective effects of compounds according to 
molecular structure. These data are relevant to antioxidant design for biological systems. Finally, I tested the effect of added ascorbate on the naphthalenediols toxicity and the protection of derivatives of $1,8-\mathrm{ND}$, more water-soluble than 1,8-ND.

\subsection{MATERIAL AND METHODS}

\section{Materials}

2,3-Naphthalenediol and 1,4-naphthalenediol (2,3-ND and 1,4-ND) were obtained from Sigma (St. Louis, MO, USA). Since all commercially available samples of 1,2-ND were found to be of unsatisfactory purity, 1,2-ND was prepared starting from 1,2naphthoquinone (Sigma) by $\mathrm{NaBH}_{4}$ reduction [20] followed by immediate acetylation (see below) of the crude diol. All syntheses (including the synthesis of 1,2-ND, 1,4dipropyl-2,3-naphthalenediol (DPND) and its diacetate (DPND-DA), 1,8-ND, 1,8-NDDA acrylate, 1,8-ND-DA acrylamide and 1,8-ND-diglycerate) were carried by Martin Charron in the Professor Durst group (University of Ottawa). 1,8-ND was prepared by heating 1,8-naphthosultone (Sigma) and $\mathrm{KOH}$ together in a stainless steel beaker at $300^{\circ} \mathrm{C}$ using a Bunsen burner [21] (for an alternative synthesis, see ref. 16). For the synthesis of DPND, commercially available 2,3-naphthalenediol (Sigma) was converted into its diallyl ether by reaction with allyl bromide in the presence of $\mathrm{K}_{2} \mathrm{CO}_{3}$ in refluxing acetone. This intermediate was dissolved in decalin and heated to $190^{\circ} \mathrm{C}$ to yield its Claisen rearrangement product. The desired diol DPND was obtained by olefin hydrogenation of the 1,4-diallyl-2,3-naphthalenediol with $30 \% \mathrm{Pd}$ on activated carbon in a hydrogen atmosphere in methanol solvent. The corresponding diacetates were prepared by reacting the diols with acetic anhydride in the presence of $\mathrm{N}, \mathrm{N}$-dimethylaminopyridine 
and triethylamine. All structures were verified by ${ }^{1} \mathrm{H}$ and ${ }^{13} \mathrm{C} \mathrm{NMR}$, as well as by mass spectrometry. AAPH, L-ascorbic acid, EGCG, (3-(3,5-dimethylthiazol-2-yl)2,5diphenyltetrazoliumbromide (MTT), dimethyl sulfoxide (DMSO) and phosphate buffered saline (PBS), xylenol orange, sorbitol, ferrous sulphate, and sulfuric acid were obtained from Sigma Chemical Co. (St. Louis, MO, USA). Hydrogen peroxide was obtained from Caledon Laboratories Ltd. (Georgetown, ON, CAN). RPMI 1640, trypsin, horse serum, newborn calf serum, and antibiotic-antimyctotic were purchased from Invitrogen (Carlsbad, CA, USA).

\section{Cell culture}

PC12-AC cells, an adherent clone of the rat adrenal pheochromocytoma cell line, were a gift from Dr. Steffany Bennett (Biochemistry, Microbiology and Immunology, University of Ottawa). The cells were thawed and grown in RPMI 1640 medium supplemented with 5\% newborn calf serum, $10 \%$ heat-inactivated horse serum, glutamine, bicarbonate, $100 \mathrm{U} / \mathrm{mL}$ penicillin $\mathrm{G}$ sodium salt, $100 \mu \mathrm{g} / \mathrm{mL}$ streptomycin sulfate and $0.025 \mathrm{mg} / \mathrm{mL}$ amphotericin B (Invitrogen). The cells were maintained at $37^{\circ} \mathrm{C}$ in a humidified atmosphere $\left(5 \% \mathrm{CO}_{2}\right.$ in air) and passed at a density of ca. $5 \times 10^{5}$ cells $/ \mathrm{mL}$ twice a week; doubling time was approximately $24 \mathrm{~h}$. Cell numbers and viability were determined by the trypan blue $(0.1 \% \mathrm{w} / \mathrm{v})$ exclusion method.

\section{Cytotoxicity test using MTT reduction assay}

The assay was described in Material and Methods, Chapter 3. Briefly, PC12-AC cells plated at a density of $2 \times 10^{5}$ cells $/ \mathrm{mL}(100 \mu \mathrm{L} /$ well $)$ were incubated for $24 \mathrm{~h}\left(37^{\circ} \mathrm{C}\right.$, 
$5 \% \mathrm{CO}_{2}$ ) to allow adherence and for another $24 \mathrm{~h}$ with medium containing test compounds. The incubation was continued for another $2 \mathrm{~h}$ with $10 \mu \mathrm{L}$ MTT stock solution $(5 \mathrm{mg} / \mathrm{mL}$ in PBS) [22-24]. The absorption values were read at $570 \mathrm{~nm}$ with background subtraction at $630 \mathrm{~nm}$ in a SpectroMax $340^{\mathrm{PC}}$ microplate reader (Molecular Devices Co., Sunnyvale CA USA). The "Control" is based on the absorbance of cells in medium only, and all treatments are expressed as a percentage of these control values in plots of cell viability.

\section{FOX1 (ferric oxidase 1) Assay}

The assay was described in Material and Methods, Chapter 3. Briefly, PC12-AC cells at a concentration of 400,000 cells $/ \mathrm{mL}$ were incubated for $24 \mathrm{~h}$ at $37^{\circ} \mathrm{C}$. The medium from the 6 wells was replaced with HBSS and the compound at a final concentration of $100 \mu \mathrm{M}$ every $15 \mathrm{~min}$ for up to $3 \mathrm{~h}$. Afterwards, $10 \mu \mathrm{L}$ of the supernatant was added to $100 \mu \mathrm{L}$ of FOX1 reagent [25] (100 mM sorbitol, 125 $\mu \mathrm{M}$ xylenol orange, $250 \mu \mathrm{M} \mathrm{FeSO}, 25 \mathrm{mM} \mathrm{H}_{2} \mathrm{SO}_{4}$ ), prepared $30 \mathrm{~min}$ in advance. Absorbance at $560 \mathrm{~nm}$ was read after $30 \mathrm{~min}$ incubation at room temperature. Levels of $\mathrm{H}_{2} \mathrm{O}_{2}$ in samples were compared to a standard curve of $\mathrm{H}_{2} \mathrm{O}_{2}(0-80 \mu \mathrm{M})$.

\section{Protection against oxidative stress}

The 96-well microplates prepared in the same way as before $\left(2 \times 10^{5}\right.$ cells $\left./ \mathrm{mL}\right)$ were incubated for $24 \mathrm{~h}$ prior to use. The used medium was then replaced with fresh medium and the test compounds were added to the wells (at final concentrations of $0-250$ $\mu \mathrm{M}$ ) and incubated for $2 \mathrm{~h}$ before the addition of AAPH (final concentration $12 \mathrm{mM}$ ). 
After $24 \mathrm{~h}$ incubation, cell viability was assayed using the MTT assay. AAPH has been shown to give carbon-centered radicals which rapidly add oxygen to give hydrophilic peroxyl radicals [26-27]. The term "Stress" is used to denote the absorbance (\% of Control) in the presence of AAPH (12 mM, $24 \mathrm{~h}$ incubation).

\section{Statistics}

Data are expressed as mean \pm SEM values. In the case of $\mathrm{EC}_{50}$ (see Figures 4.2, 4.4, 4.9-4.15) and CPA (see Figures 4.7, 4.8, 4.16-4.18) the same treatment as described in Chapter 3- statistics was applied to calculate the error of the $\mathrm{EC}_{50}$ and CPA, respectively. Statistical significance was assessed by using one-way ANOVA. Differences were considered significant at $p<0.05$.

\section{Calculation of BDE}

The method of calculation was presented in the previous chapters. It was used the lowest-level method (LLM) as described by DiLabio et al. [28].

\section{Calculation of $\log P$}

The calculation of the octanol-water partition coefficent, Log P, was done using Advanced Chemistry Development Software (ACD Labs, Software Solaris V4.67) available through a structure search on SciFinder Scholar 2004 [29]. 


\subsection{RESULTS}

\section{Experimental}

All of the compounds, with the exception of EGCG, were prepared in their diacetylated form. The purpose of acetylation is to provide protection against extracellular autoxidation, which does not occur in the acetylated form (see also ref. [18]). Figure 4.1 shows structures for the 9 compounds tested. 
<smiles>CC(=O)Oc1ccc2ccccc2c1OC(C)=O</smiles>

1,2-ND-DA<smiles>CC(=O)Oc1ccc(OC(C)=O)c2ccccc12</smiles>

1,4-ND-DA<smiles>CC(=O)Oc1cccc2cccc(OC(C)=O)c12</smiles>

1,8-ND-DA<smiles>CC(=O)Oc1cc2ccccc2cc1OC(C)=O</smiles>

2,3-ND-DA<smiles>O=C(O[C@H]1Cc2c(O)cc(O)cc2O[C@H]1c1cc(O)c(O)c(O)c1)c1cc(O)c(O)c(O)c1</smiles>

DPND-DA<smiles>CCCc1c(OC(C)=O)c(OC(C)=O)c(CCC)c2ccccc12</smiles><smiles>CC(C)(C)c1cc(O)c(O)c(C(C)(C)C)c1</smiles><smiles>CC(=O)Oc1cccc2c(C=CC(N)=O)ccc(OC(C)=O)c12</smiles>

1,8-ND-DA 4-acrylamide<smiles>[R]Oc1cccc2cccc(O[R])c12</smiles>

\section{1,8-ND-diGlycerate}

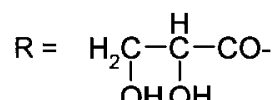<smiles>COC(=O)/C=C/c1ccc(OCC(=O)OC)c2c(OC(C)=O)ccc(OC(C)=O)c12</smiles>

Figure 4.1. Structural formulas for the 9 compounds tested, where $1,2-\mathrm{ND}-\mathrm{DA}=1,2-$ naphthalenediol-diacetate, 1,8-ND-DGly $=1,8-\mathrm{ND}$-diglycerate and EGCG $=(-)-$ epigallocatechin gallate. 
Figure 4.2 shows the cytotoxicity vs. concentration for the 6 compounds, where the dashed line represents the effective concentration (MTT assay) for which the absorbance/cell viability is reduced to $50 \%$ of control. There is clearly a wide range of cytotoxicity among the various naphthalenediols, ranging from 1,4-ND (most toxic) to $1,8-\mathrm{ND} \approx 2,3-\mathrm{ND}$ (least toxic). Even less cytotoxic is EGCG, an interesting result since this molecule contains the pyrogallol moiety which is known to autoxidize rapidly [30].

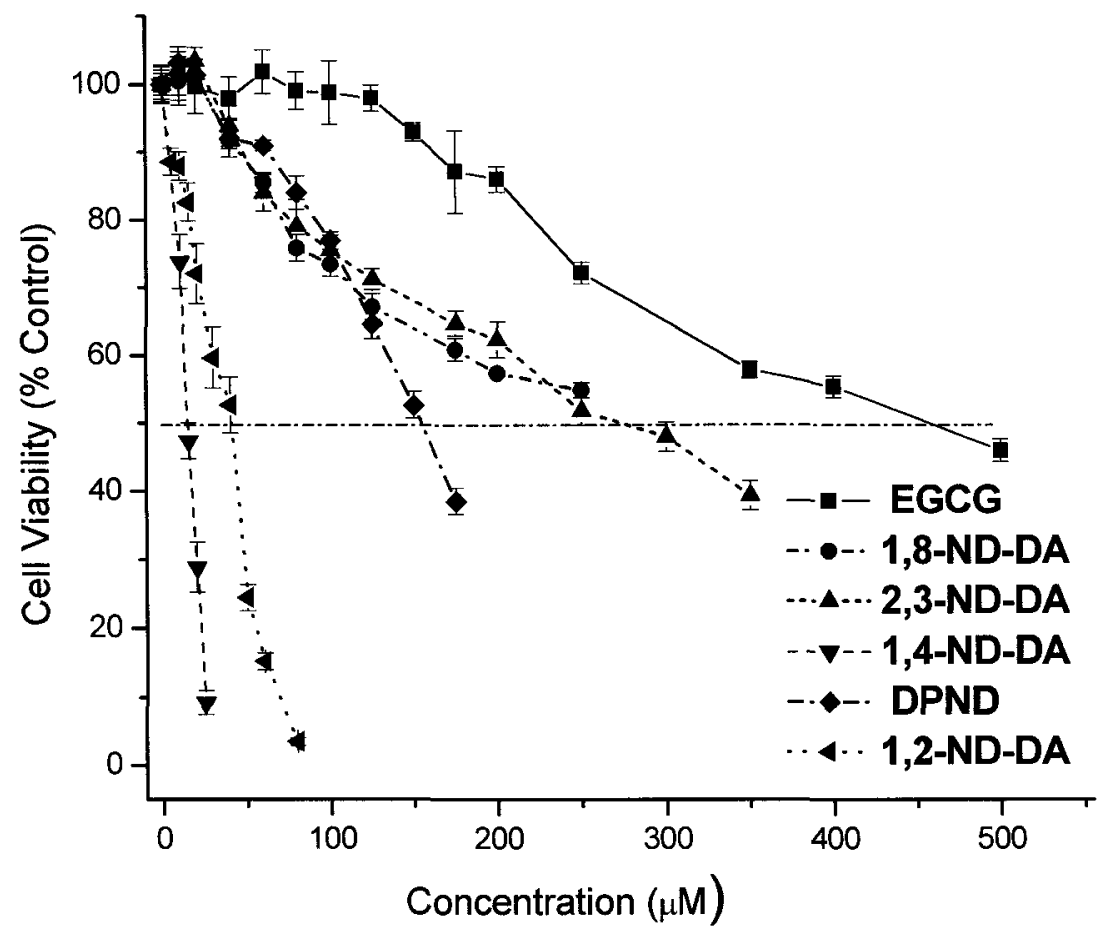

Figure 4.2. Cytotoxicity of the naphthalenediols, initially present as the diacetates, and the reference compound EGCG. Incubation time: $24 \mathrm{~h}$.

In order to explain the toxicity of naphthalenediols I measured the amount of $\mathrm{H}_{2} \mathrm{O}_{2}$ generated. Figure 4.3 shows the amount of $\mathrm{H}_{2} \mathrm{O}_{2}$ generated as a function of time, for $100 \mu \mathrm{M}$ concentration of the naphthalenediols. In these experiments, the medium was 
removed, then the compound was added to cells in HBSS and incubated over a variable time period, followed by measurement of $\mathrm{H}_{2} \mathrm{O}_{2}$ in the supernatant. 1,2-ND and 1,4-ND showed a faster rise in time; in the case of 1,4-ND did I see a maximum in $\mathrm{H}_{2} \mathrm{O}_{2}$ concentration, followed by a rapid decline. Figure 4.3 shows that the amount of $\mathrm{H}_{2} \mathrm{O}_{2}$ produced in $2 \mathrm{~h}$ in the case of 1,8-ND, DPND and 2,3-ND is essentially background (at ca. $1 \mu \mathrm{M}$ ), or even less, and never rises above background even at concentrations of the compounds which are above the $\mathrm{EC}_{50}$.

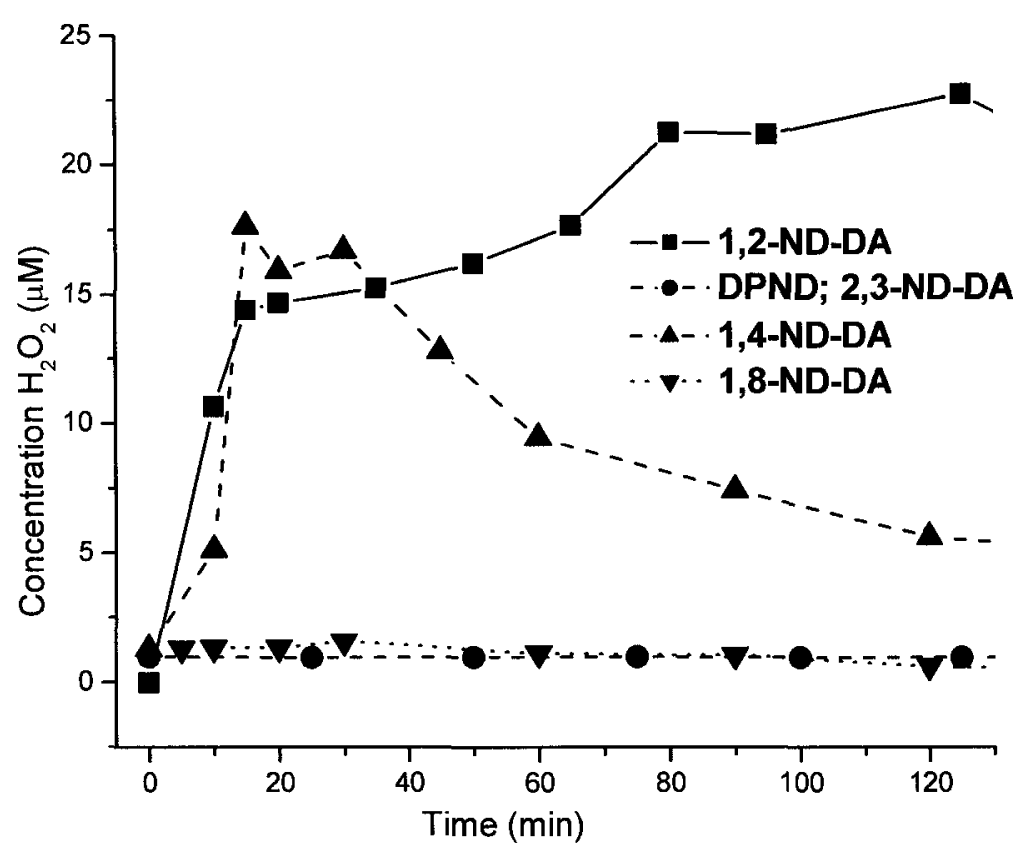

Figure 4.3. $\mathrm{H}_{2} \mathrm{O}_{2}$ response curves as a function of time (FOX1 assay) for each test compound in its diacetate form.

Figure 4.4 shows the cytotoxicity caused by the oxidative stressor AAPH which generates peroxyl radicals $\mathrm{ROO}^{\circ}$ at a relatively constant rate. Since the MTT assay measures only live (metabolizing) cells, it cannot distinguish between cell death and 
inhibition of cell growth. The inhibition process has been demonstrated for resveratrol, catechols [31] and polyphenols [32]. Since the doubling time of $24 \mathrm{~h}$ is sufficiently rapid that there can be confusion between these two sources of reduced cell population, I use the term $\mathrm{EC}_{50}=$ Effective Concentration which reduces formazan blue absorbance to $50 \%$ of control. This is labeled cell viability (expressed as a percentage of Control (no stressor)) in Figure 4.3 and following. For $\mathrm{AAPH}$, the $\mathrm{EC}_{50}=10.5 \pm 3 \mathrm{mM}$.

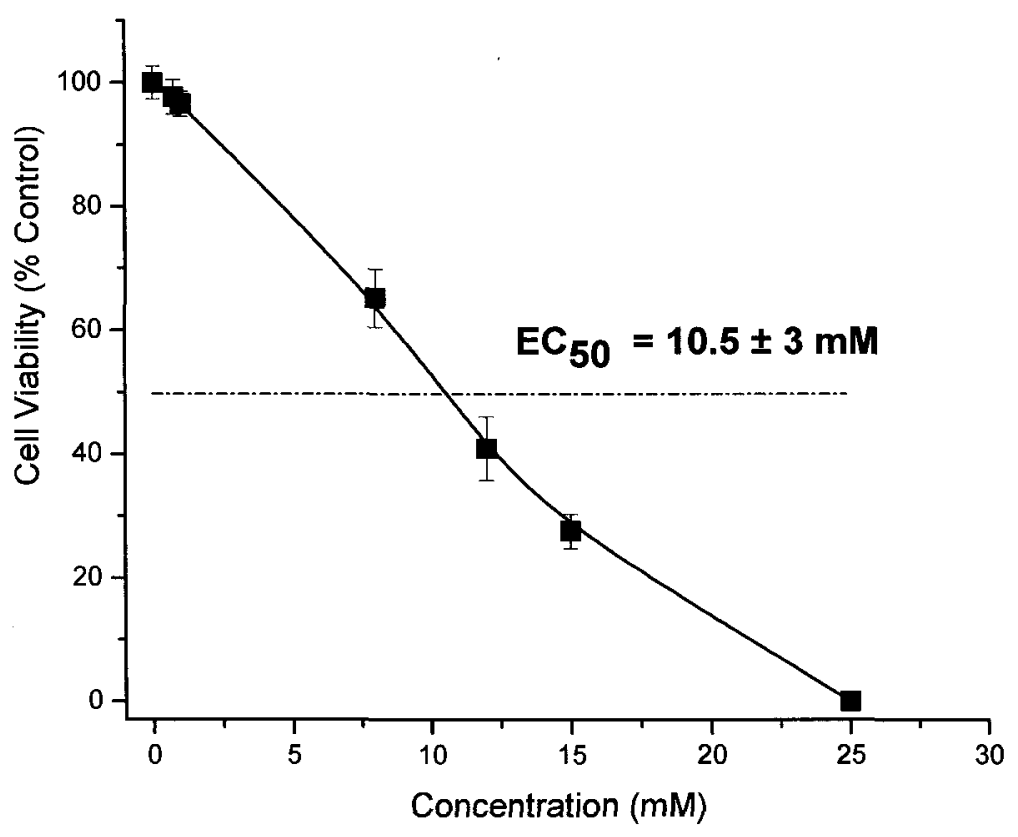

Figure 4.4. Cell viability (MTT assay) for PC12-AC cells vs. concentration of AAPH.

Figure 4.5 shows the cytoprotection of 1,2-ND-DA, 1,4-ND-DA and EGCG against the oxidative stress caused by AAPH, where the AAPH concentration was set at $12 \mathrm{mM}$. This was sufficient to reduce cell viability to $40 \pm 5 \%$ of Control. Since the post-AAPH treated cells had $42 \%$ viability, the protective range remaining spans from 42-100\% of Controls. The concentration, which inhibits half of the original loss in 
viability, is therefore $71 \%$, and an $\mathrm{IC}_{50}$ for this particular cell type (PC12-AC), this stressor (AAPH at $12 \mathrm{mM}, 24 \mathrm{~h}$ ), and each compound shown could therefore be defined. However, \% viability for compounds can easily cross the $\mathrm{IC}_{50}$ line twice (on the way up and on the way down, see Figure 4.6 for $1,8-\mathrm{ND}-\mathrm{DA})$, so the $\mathrm{IC}_{50}$ definition was problematic and was not used.

As can be seen in Figure 4.5, the 1,2-ND-DA has only a slight protective effect above "Stress", and then beyond ca. $10 \mu \mathrm{M}$ its inherent cytotoxicity begins to take its toll on the cells. The 1,4-ND-DA shows a definite protective effect in a range out to $10 \mu \mathrm{M}$ (no further data were taken beyond this range due to increasing toxicity).

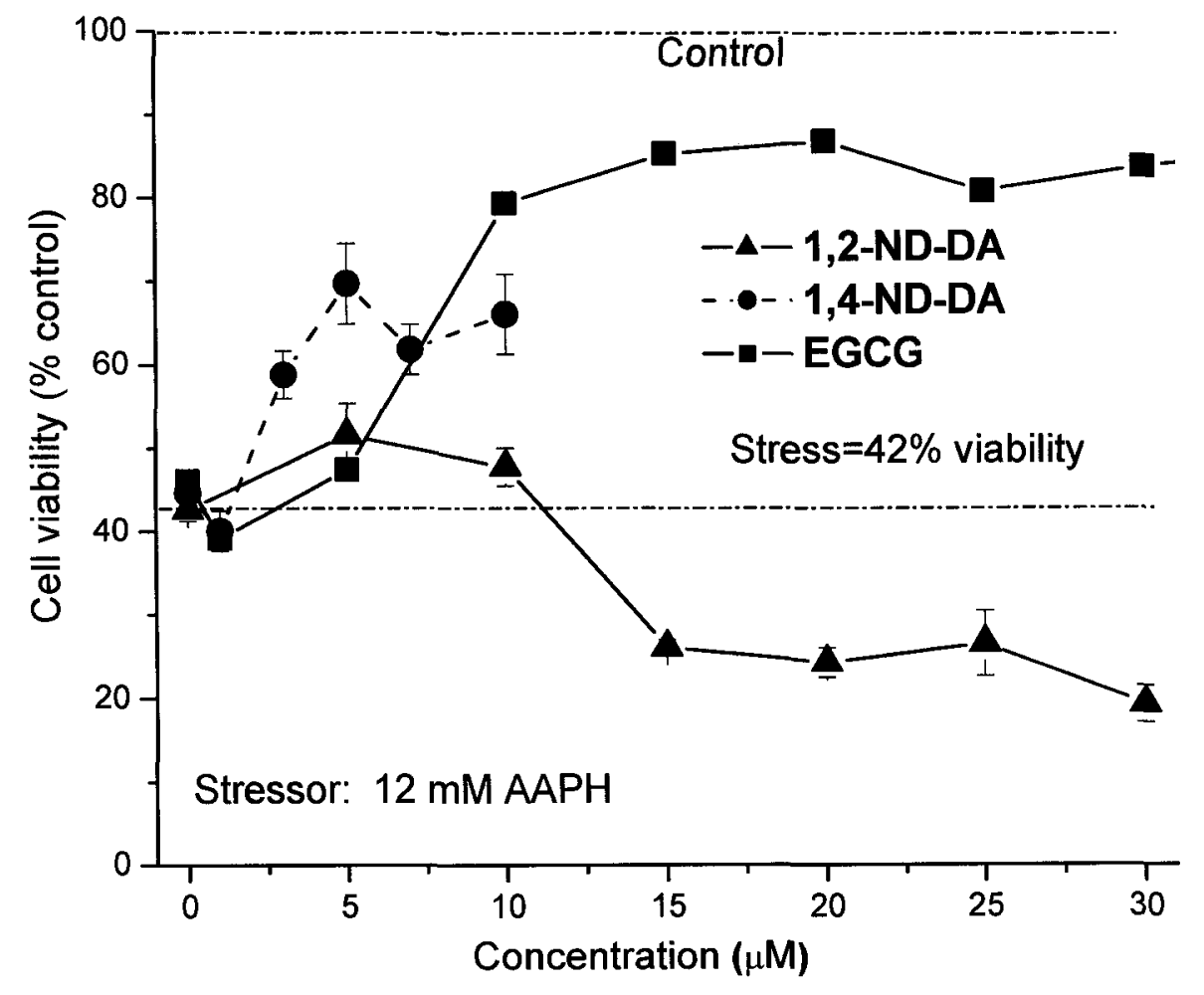

Figure 4.5. Cytoprotection against AAPH-induced oxidative stress for compounds 1,2ND-DA and 1,4-ND-DA. 
Figure 4.6 shows cytoprotection caused by adding 1,8-ND-DA, 2,3-ND-DA and DPND-DA and EGCG to the AAPH-treated cells. The range has now been expanded to 0-60 $\mu \mathrm{M}$ and could have been increased still further since all the compounds continue to be protective in the observed range. 1,8-ND (for simplicity, I omit the DA notation from this point on) was most strongly protective over the range shown, although its maximum was near $20 \mu \mathrm{M}$. On the other hand, 2,3-ND showed a more linear dose-response curve. EGCG is more strongly protective and at $50 \mu \mathrm{M}$ has reached the value of Control (i.e. maximum protection); the slight exceeding of Control is due to experimental error.

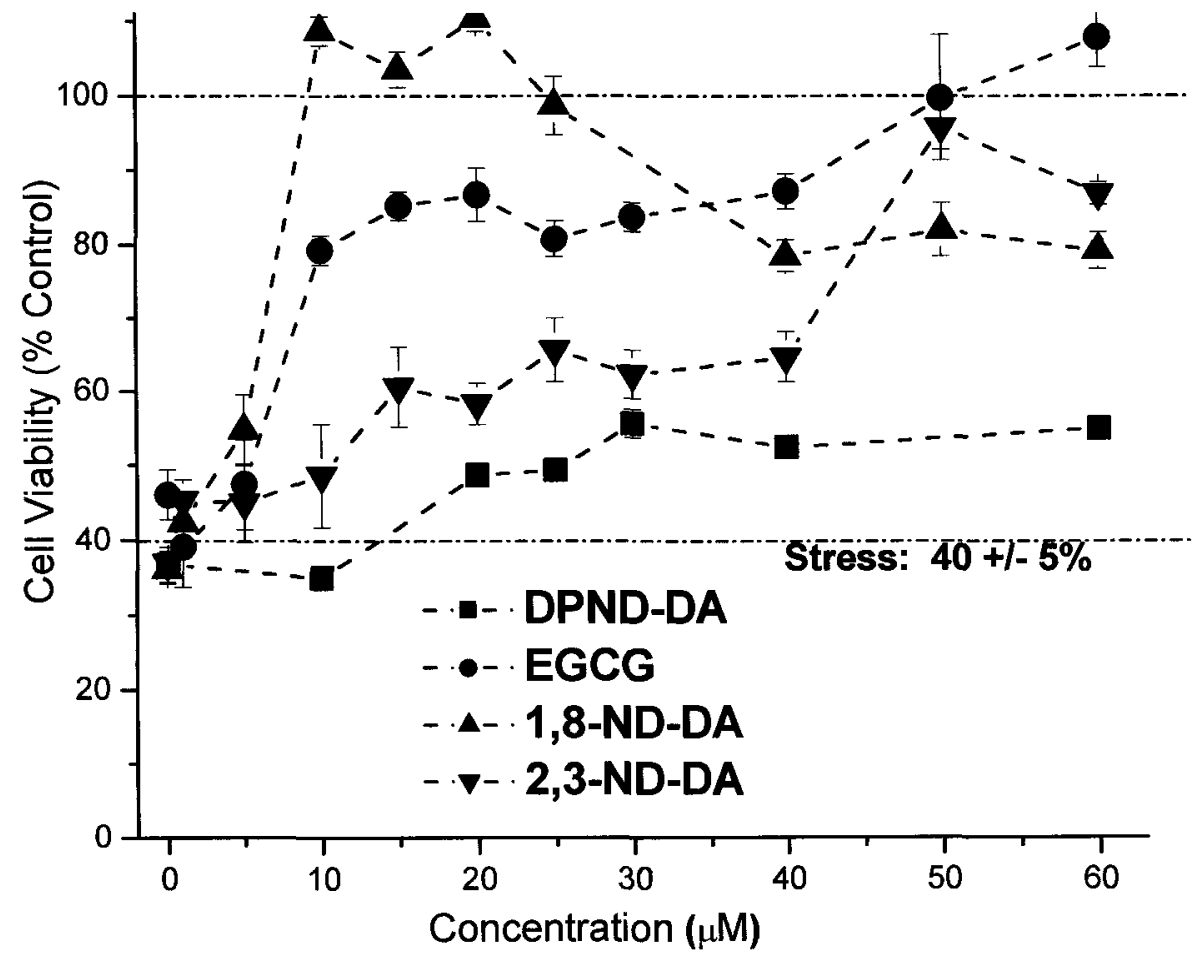

Figure 4.6. Cytoprotection of $\mathrm{PC} 12-\mathrm{AC}$ cells by naphthalenediols with AAPH (12 mM) as a stressor including 2,3-ND, 1,8-ND, DPND (as diacetates), and EGCG. 
Figure 4.7 shows the relevant data for EGCG. In the presence of AAPH, but without EGCG, "Stress" was 39\% of Control values (12 mM, $24 \mathrm{~h}$ incubation). The lefthand side of the Protection Zone is defined by the cytoprotection experiment (data from Figure 4.4 for EGCG, shown as triangles). The cytotoxicity envelope provides the upper curve (filled circles), and since the data were from 0 to $500 \mu \mathrm{M}$ I extrapolated from 500 $580 \mu \mathrm{M}$ to obtain the final portion (cytotoxicity extrapolation, dotted line). The bottom boundary of the protective zone, or "Stress", is the viability in presence of AAPH (39\% in this experiment). Then for EGCG I can characterize the cytoprotection against AAPHinduced stress by (i) its protective range, in this case $0-580 \mu \mathrm{M}$, (ii) the maximum peak in protection, in this case $100 \pm 5 \%$ viability at $60 \mu \mathrm{M}$ concentration, or (iii) the "Cytoprotective Area" (CPA), which is the area between the boundaries described above (total cross-hatched area, Figure 4.7). 


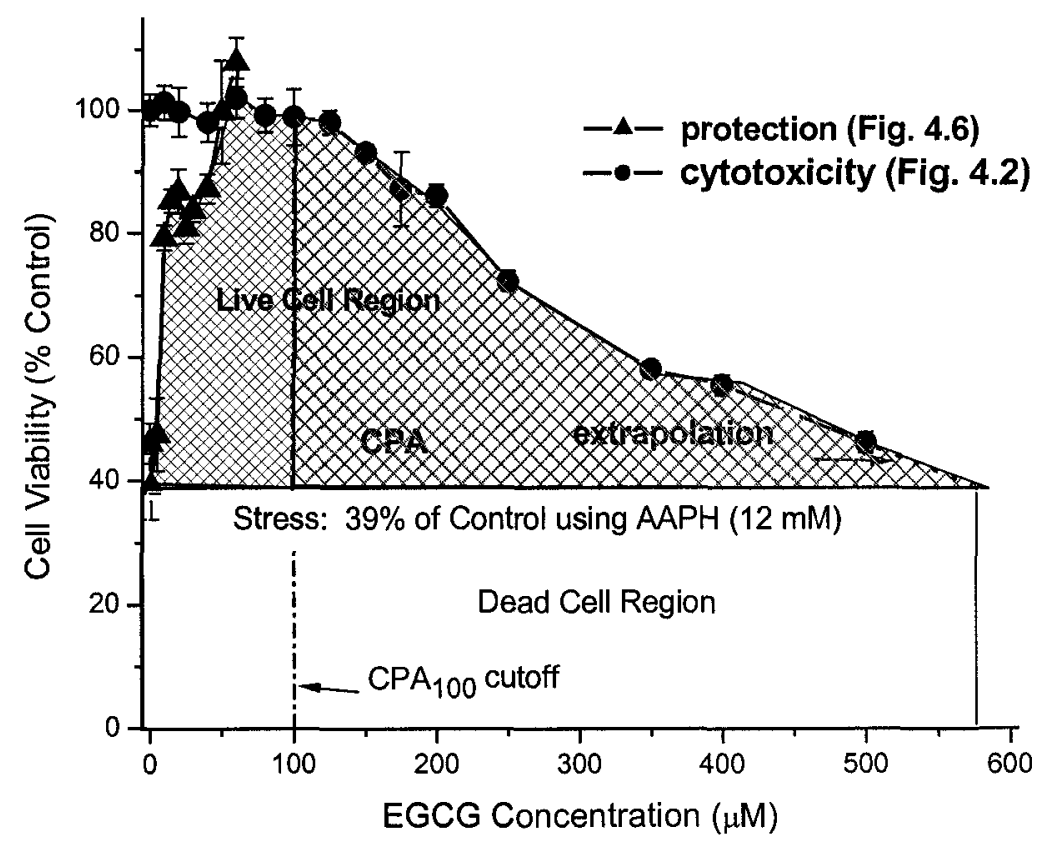

Figure 4.7. Total Cytoprotective area for EGCG (both cross-hatched regions). Boundaries: Cytoprotection experiment (from Figure 4.6) at left (triangles), cytotoxicity envelope (from Figure 4.2) at top (filled circles), extrapolated region $500-580 \mu \mathrm{M}$ (dotted line), viability in presence of AAPH Stress (solid line, 39\% Control). CPA C $_{100}$ : dark cross-hatched region only.

One assumption I made in constructing Figure 4.7 is that the graph for the cytoprotection experiment (solid triangles), which was only carried out up to $60 \mu \mathrm{M}$, will intersect and become coincident with the cytotoxicity data (solid circles). To verify that this was true, I continued the cytoprotection experiment for $2,3-\mathrm{ND}$ out to larger concentrations. Figure 4.8 shows that data for the two experiments do indeed become coincident, to within experimental error, so that an average can be drawn beyond $50 \mu \mathrm{M}$ (dark solid line) which encloses the cytoprotective area. 


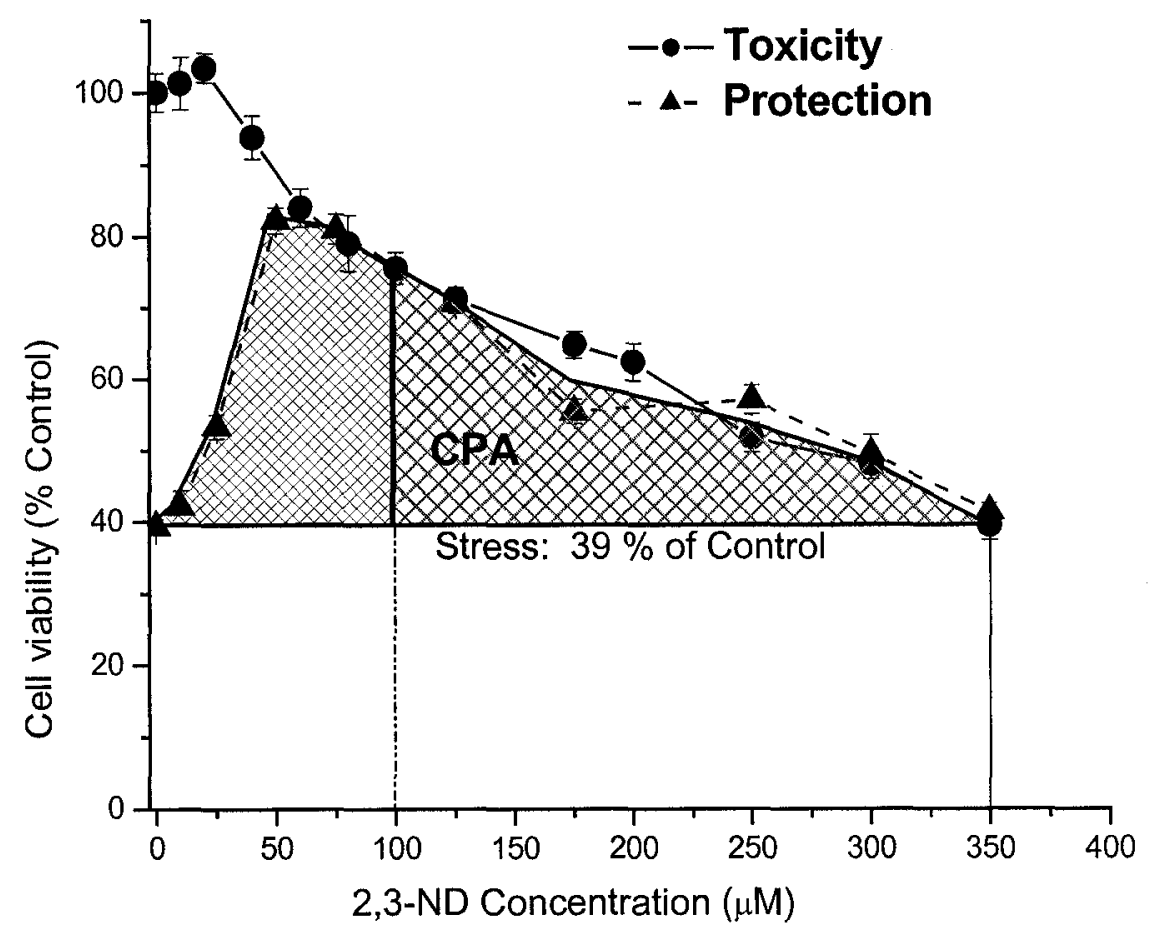

Figure 4.8. Total Cytoprotective area for 2,3-ND (both cross-hatched regions), showing a more extended cytoprotection experiment, with data out to $350 \mu \mathrm{M}$. Stressor: AAPH $(12 \mathrm{mM})$

Studies of the effect of ascorbate on cytotoxicity of the NADOLS

Figure 4.9 shows the number of viable PC12-AC cells (from MTT assay) vs concentration for Vitamin $\mathrm{C}$. Ascorbate anion (since solution $\mathrm{pH}=7.4$ ) is very non-toxic $\left(\mathrm{EC}_{50}>200 \mu \mathrm{M}\right)$. The concentration of $75 \mu \mathrm{M}$ Vitamin $\mathrm{C}$ that is used in the tests with naphthalenediols is non-toxic. 


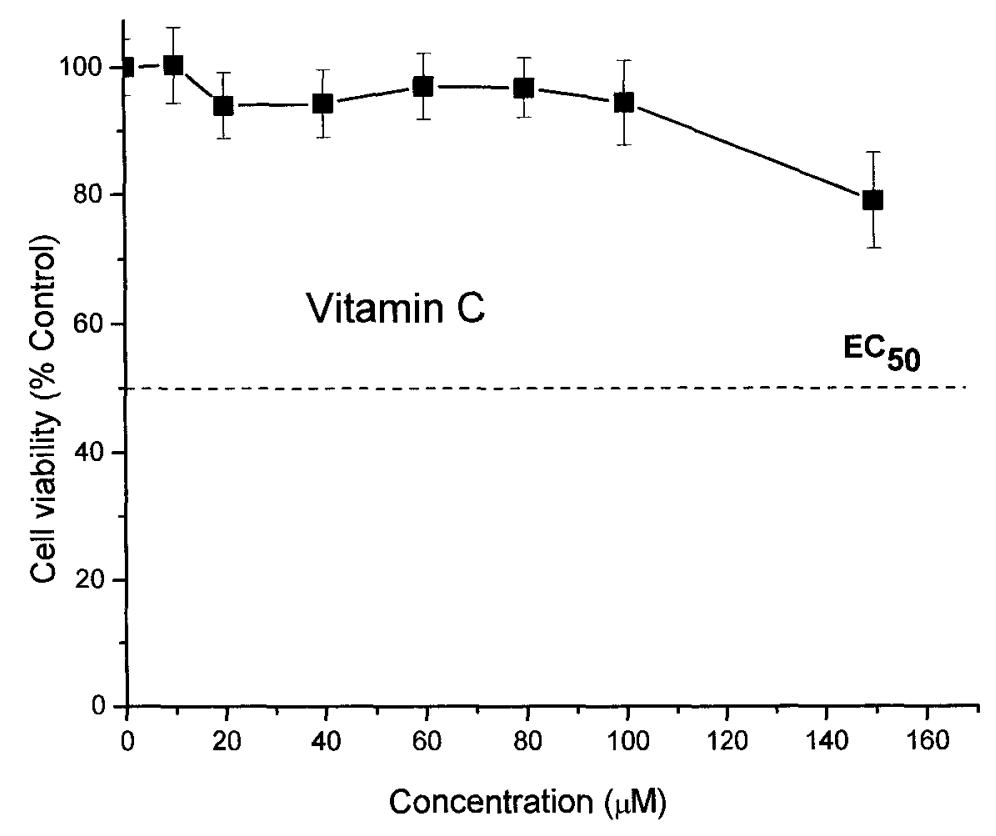

Figure 4.9. Cell viability (MTT assay) for PC12-AC cells vs concentration of Vit. C.

Figures $4.10-4.14$ show the number of viable PC12-AC cells, as determined using the MTT assay, for some of the compounds in Figure 4.1, as well as the effect of adding ascorbate at $50 \mu \mathrm{M}$ or $75 \mu \mathrm{M}$. The effective concentration which reduces the number of live cells to $50 \%$ of control will be denoted $\mathrm{EC}_{50}$ in the discussion to follow.

Figure 4.10 shows that 1,8-ND, in the presence and absence of added ascorbate, had essentially the same behavior $\left(\mathrm{EC}_{50}\right.$ value higher than $\left.250 \mu \mathrm{M}\right)$. Ascorbate gives a significant protective effect to DPND, with the $\mathrm{EC}_{50}$ value increasing to $200 \mu \mathrm{M}$ in the presence of $50 \mu \mathrm{M}$ ascorbate (Figure 4.11), and even higher protection $\left(\mathrm{EC}_{50}>200 \mu \mathrm{M}\right.$ ) in the presence of $75 \mu \mathrm{M}$ ascorbate (data not shown). Figure 4.12 shows that the same protective effect of ascorbate is evident for the much less toxic $2,3-\mathrm{ND}$, where $75 \mu \mathrm{M}$ ascorbate reduces the toxicity still further. 
In contrast, with 1,2-ND (Figure 4.13), ascorbate increases the cytotoxicity significantly $(40 \rightarrow 7.5 \mu \mathrm{M})$, making this one of the more cytotoxic combinations of the molecules studied here. 1,4-ND (Figure 4.14) has a somewhat different response, showing little difference with or without added ascorbate $\left(\mathrm{EC}_{50}\right.$ of $\left.15 \mu \mathrm{M}\right)$.

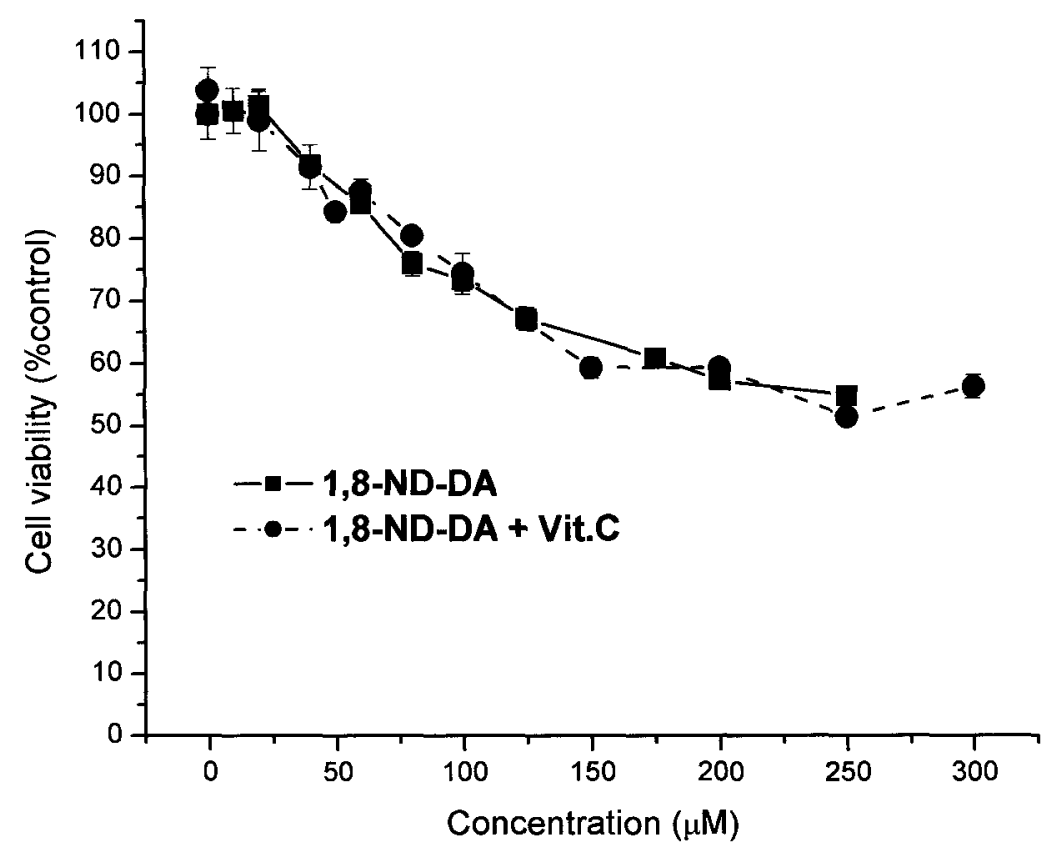

Figure 4.10. Cytotoxicity response curve for 1,8 ND-DA and 1,8 ND-DA with $75 \mu \mathrm{M}$ ascorbate 


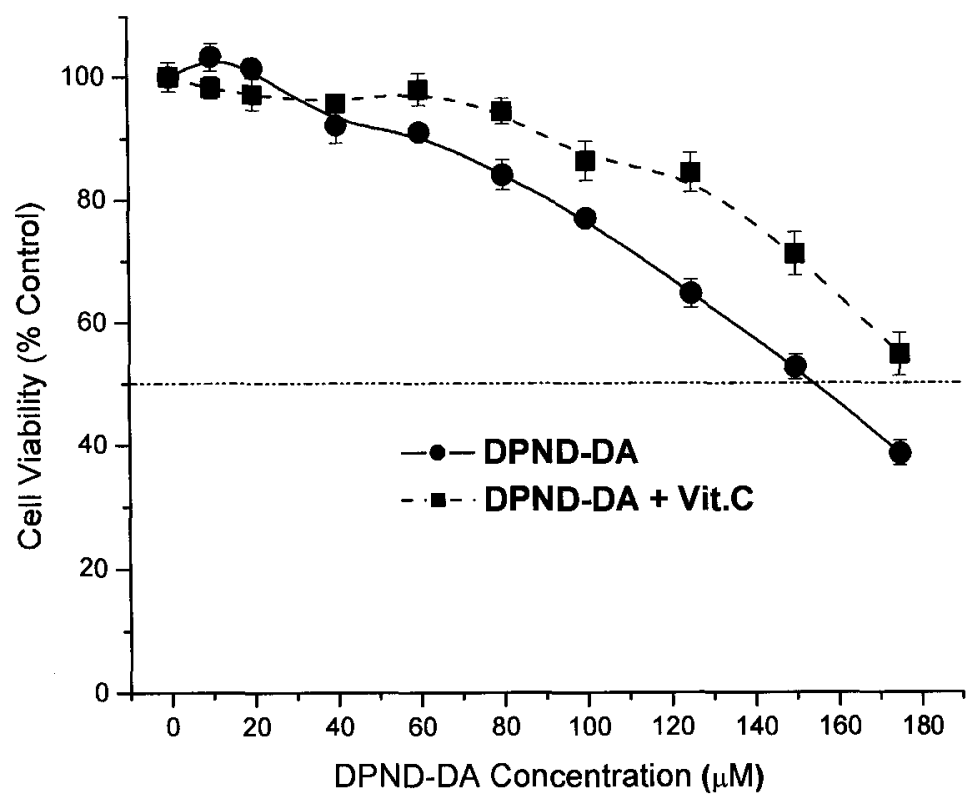

Figure 4.11. Cytotoxicity response curve for DPND-DA and DPND-DA with $50 \mu \mathrm{M}$ ascorbate.

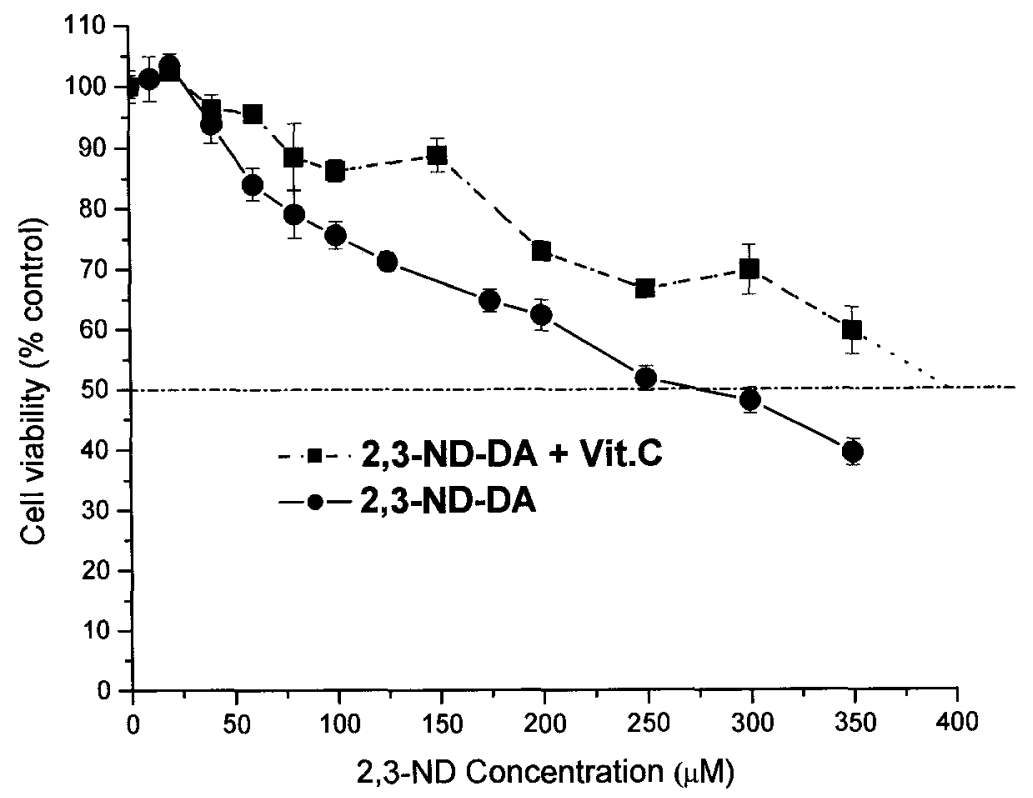

Figure 4.12. Cytotoxicity response curve for 2,3ND-DA and 2,3ND-DA with $75 \mu \mathrm{M}$ ascorbate. 


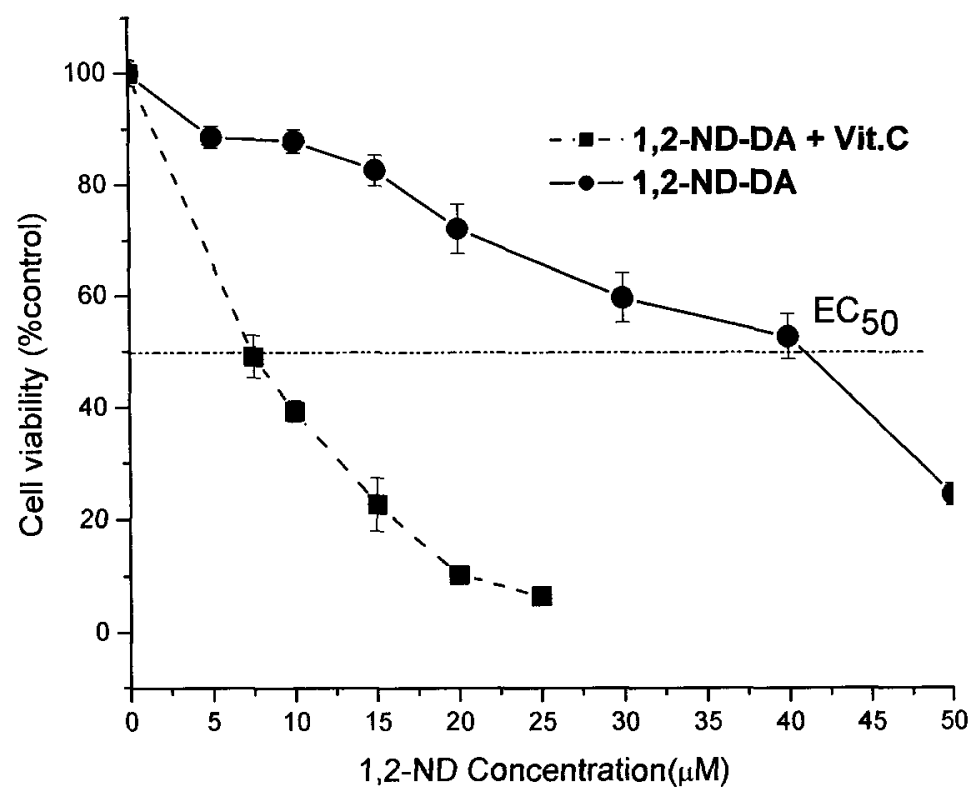

Figure 4.13. Cytotoxicity response curve for $1,2 \mathrm{ND}-\mathrm{DA}$ and $1,2 \mathrm{ND}-\mathrm{DA}$ with $50 \mu \mathrm{M}$ ascorbate.

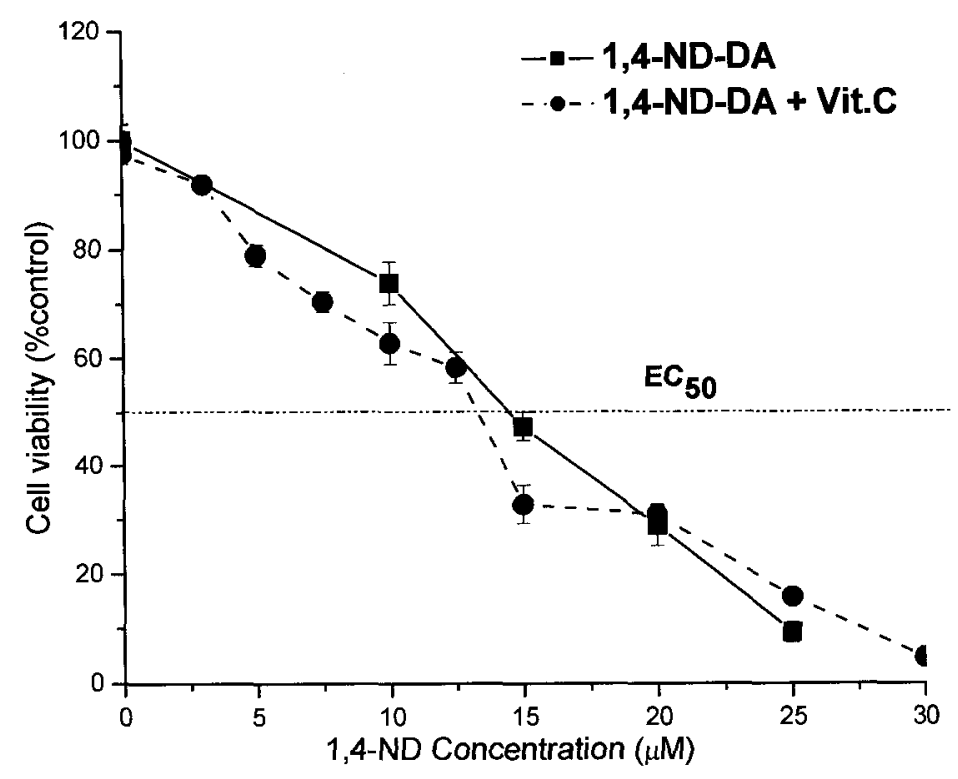

Figure 4.14. Cytotoxicity response curve for 1,4ND-DA and 1,4ND-DA with $50 \mu \mathrm{M}$ ascorbate. 


\section{Toxicity and cytoprotection studies of derivatives of $1,8-N D$}

1,8-ND-DA showed a very strong protective effect but the compound has a poor solubility in aqueous solutions. We therefore designed and tested three derivatives of 1,8-ND that were more water soluble. 8-ND acrylate and 1,8-ND-DGly have a toxicity similar with $1,8-\mathrm{ND}\left(\mathrm{EC}_{50}=250 \mu \mathrm{M}\right)$. Less cytotoxic is $1,8-\mathrm{ND}$ acrylamide with an $\mathrm{EC}_{50}$ of $375 \mu \mathrm{M}$.

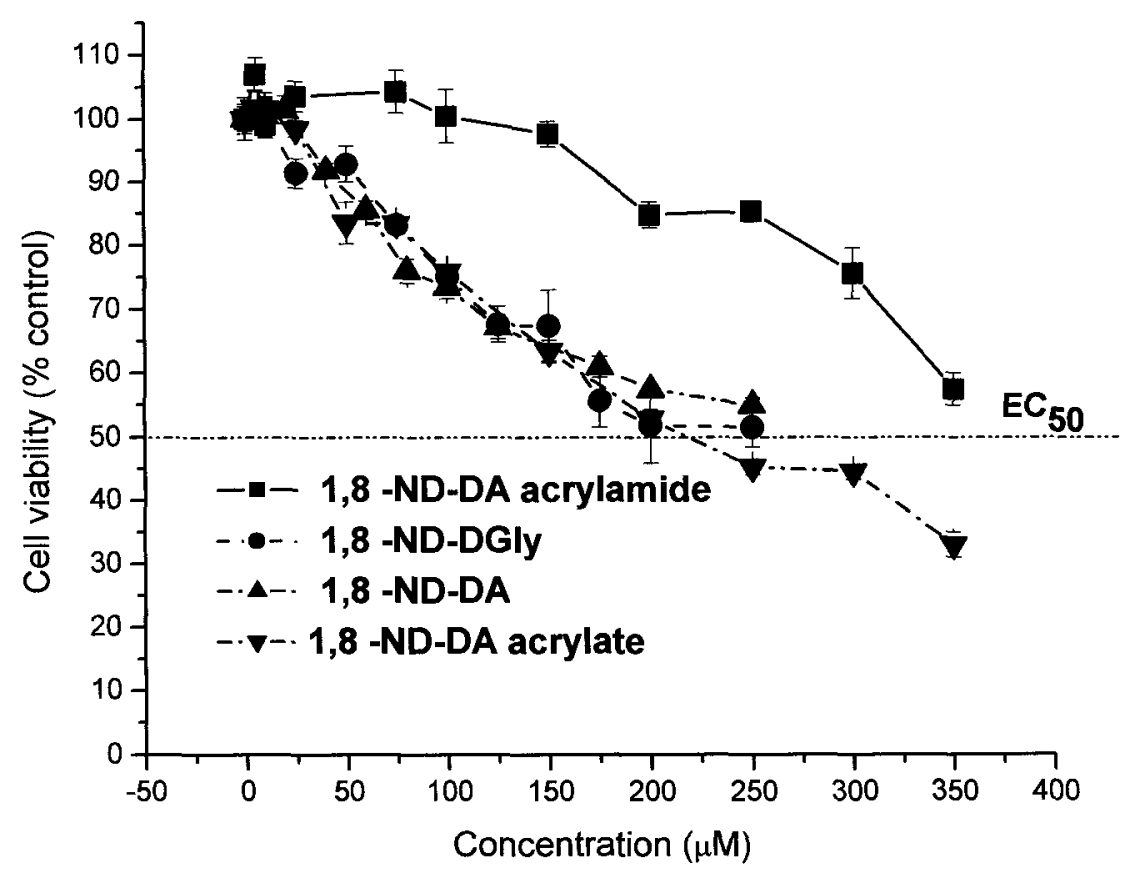

Figure 4.15. Cytotoxicity of the 1,8 -ND-DA and substituted 1,8 -NDs (1,8-ND-DA acrylamide; 1,8-ND-DA acrylate, 1,8-ND-DGly)

Figures 4.16-4.18 show the relevant cytoprotection data for 1,8-ND derivatives. In the presence of AAPH, but without compound tested, Stress was $40 \% \pm 7$ of Control (12 mM, $24 \mathrm{~h}$ incubation). For 1,8-ND-DA acrylate and 1,8-ND-DGly the left-hand side 
of the Protection Zone is defined by the cytoprotection experiment and the cytotoxicity envelope provides the upper curve. For 1,8-ND-DA acrylamide the cytotoxicity envelope doesn't play any role in defining the cytoprotective area because the protection curve doesn't intersect the cytotoxicity curve (Figure 4.17). The protective range is between 5-300 $\mu \mathrm{M}$ for 1,8-ND-DGly (with maximum protection (75\% viability) at 50 $\mu \mathrm{M})$ and $1,8-\mathrm{ND}-\mathrm{DA}$ acrylamide with maximum protection $(75 \%$ viability) at $60 \mu \mathrm{M})$ and 5-260 $\mu \mathrm{M}$ for $1,8-\mathrm{ND}-\mathrm{DA}$ acrylate (with maximum protection ( $80 \%$ viability) at 75 $\mu \mathrm{M})$.

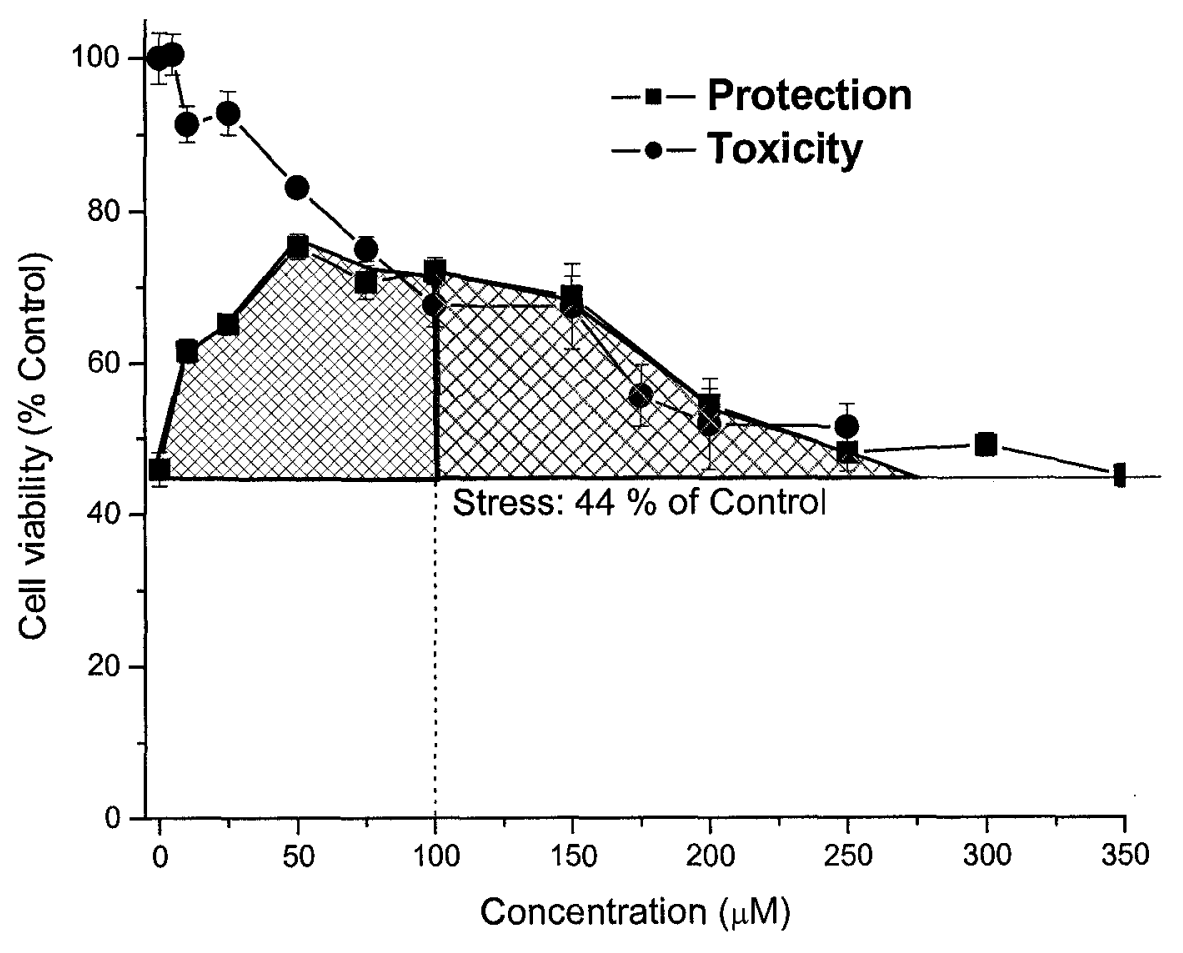

Figure 4.16. Total Cytoprotective area for 1,8-ND-DGly (both cross-hatched regions), showing an extended cytoprotection experiment, with data up to $300 \mu \mathrm{M}$. Boundaries: Cytoprotection experiment at left (square), cytotoxicity envelope at top (filled circles), viability in presence of AAPH stress (solid line, $44 \%$ relative to Control). 


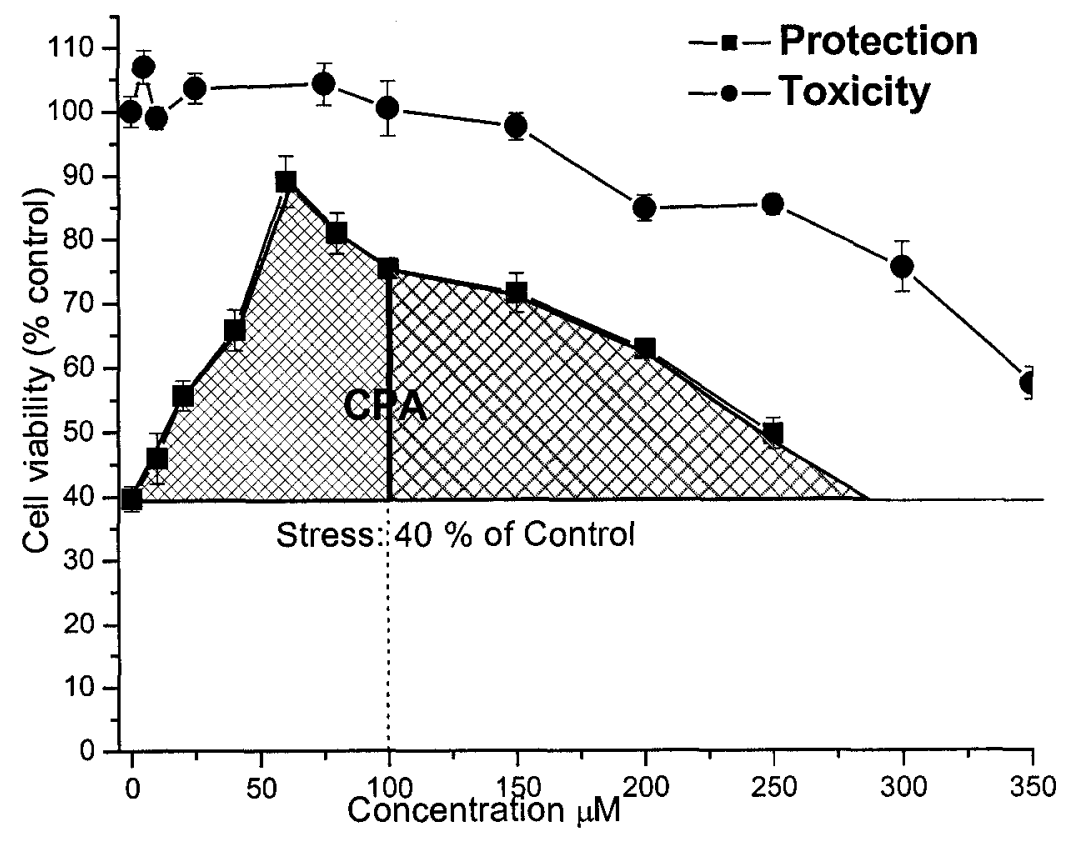

Figure 4.17. Total Cytoprotective area for 1,8-ND-DA-acrylamide (both cross-hatched regions), showing an extended cytoprotection experiment, with data up to $300 \mu \mathrm{M}$. 


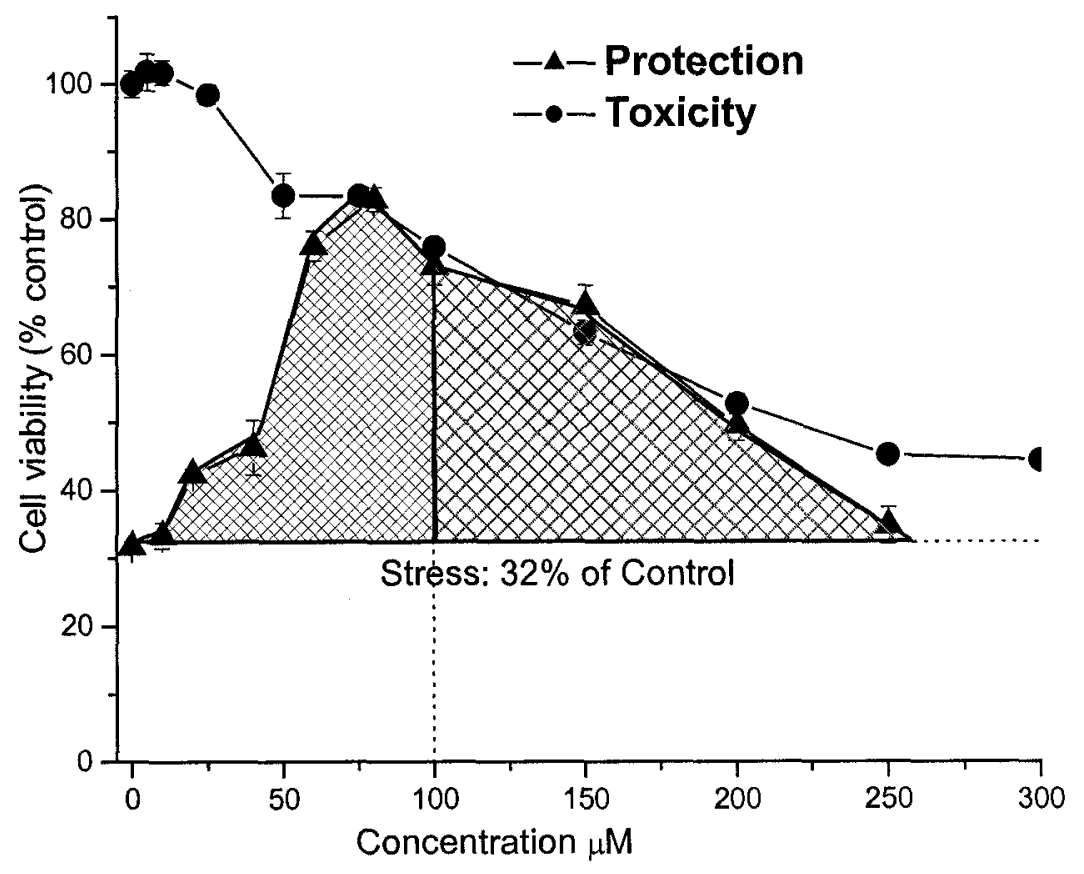

Figure 4.18. Total Cytoprotective area for substituted 1,8-ND-DA acrylate (both crosshatched regions). Boundaries: Cytoprotection experiment at left (triangles), cytotoxicity envelope at top (filled circles), viability in presence of AAPH stress (solid line, 44\% relative to Control)

\section{Theoretical}

Table 4.1 shows the calculated results for $\mathrm{BDE}_{1}$ (in generic notation $\mathrm{NQH}_{2} \rightarrow$ $\mathrm{NQH}^{\bullet}$, where $\mathrm{NQ}=$ naphthoquinone $)$ and $\mathrm{BDE}_{2}\left(\mathrm{NQH}^{\bullet} \rightarrow \mathrm{NQ}\right)$, the calculated octanolwater partition coefficient $\operatorname{LogP}$, the $\mathrm{pK}_{\mathrm{a}}$ of the parent $\mathrm{NQH}_{2}$, and the cytotoxicity of compounds with and without ascorbate expressed as the $\mathrm{EC}_{50}$. 
Table 4.1. Bond dissociation enthalpy $\left(\Delta \mathrm{H}^{\mathrm{o}}{ }_{298}\right)$, calculated $\log \mathrm{P}(\log \mathrm{P}), \mathrm{pKa}$, and $\mathrm{EC}_{50}$ of naphthalenediols with and without ascorbate, $\mathrm{BDE}_{1}$ is for naphthalenediol $\rightarrow$ naphthosemiquinone, $\mathrm{BDE}_{2}$ is for naphthosemiquinone $\rightarrow$ naphthoquinone.

\begin{tabular}{|c|c|c|c|c|c|c|}
\hline Compound & $\begin{array}{l}\mathrm{BDE}_{\mathrm{I}} \\
\mathrm{kcal} \mathrm{mol}^{-1}\end{array}$ & $\begin{array}{c}\mathrm{BDE}_{2} \\
\mathrm{kcal} \mathrm{mol}^{-1}\end{array}$ & $\log P^{2}$ & $\mathrm{pK}_{\mathrm{a}}(\text { Diol })^{\mathrm{a}}$ & $\mathrm{EC}_{50}(\mu \mathrm{M})$ & $\begin{array}{l}\mathrm{EC}_{50} \text { of the compound } \\
\text { tested + ascorbate }(\mu \mathrm{M})\end{array}$ \\
\hline 1,4-ND & 75 & 55 & 1.88 & 10.3 & $14 \pm 0.6$ & $14 \pm 0.5$ \\
\hline $1,2-\mathrm{ND}$ & 70 & 69 & 2.11 & 8.17 & $40 \pm 3$ & $7.5 \pm 0.5$ \\
\hline$\overline{\text { DPND }}^{6}$ & 75 & 86 & 5.16 & 9.27 & $155 \pm 4$ & $185 \pm 5$ \\
\hline 2,3-ND & 79 & $\overline{84}$ & 2.11 & 9.10 & $273 \pm 20$ & $>350$ \\
\hline $1,8-\mathrm{ND}$ & 72 & $104^{\mathrm{a}}$ & 1.93 & 6.36 & $>250$ & 250 \\
\hline 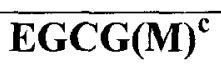 & 71 & 74 & 0.75 & 9.29 & --- & ---- \\
\hline $\mathrm{EGCG}^{\mathrm{d}}$ & 71 & 74 & 2.04 & 8.38 & $456 \pm 16$ & ---- \\
\hline
\end{tabular}

${ }^{\mathrm{a}}$ Calculated log P, using Advanced Chemistry Development (ACD Labs, Software: Solaris V4.67) in SciFinder Scholar [29].

b1,4-dipropyl-2,3-naphthalenediol

${ }^{c}$ EGCG model compound, 4-methyl-1,2,3-trihydroxybenzene

${ }^{\mathrm{d}} \mathrm{BDE}_{1}$ and $\mathrm{BDE}_{2}$ are based on on calculations for EGCG model compound 


\subsection{DISCUSSION}

Given the data on cytotoxicity (Figure 4.2), the reduction in cell viability due to AAPH (Figure 4.3) and the protection against AAPH-induced cell loss by the various naphthalenediols and EGCG (Figures 4.4-4.5), it is of interest to compare the efficacy of the various compounds on some common basis. "Control" is based on absorbance (MTT assay) of cells plus medium, and "Stress" corresponds to the absorbance of cells plus medium in the presence of $\mathrm{AAPH}$, without compound; this is converted to a percent viability in comparison to Control.

One problem in using these definitions is that the baseline varies in experiments done on different days, due to unavoidable variations in plating density, a parameter which has some effect on the toxic response of the cells. Thus, the cell viability after AAPH incubation for $24 \mathrm{~h}$ may range between $40 \pm 5 \%$ (see Figure 4.5). This makes comparison between experiments on different compounds imperfect. It would be possible to normalize the data by setting the baseline equal to zero in each experiment, but in the interest of simplicity, I have not done that and accept that there is some variation in the "Stress" baseline. This imprecision will not obscure the general validity of the conclusions but could affect the comparison between closely similar compounds, e.g. 2,3-ND and 1,8-ND.

Table 2 shows the result of treating each compound in the same way as 2,3-ND. Clearly the most useful protective index is the Cytoprotective Area (CPA), the integral of the region where cell viability exceeds that of the cells remaining after AAPH treatment. The CPA order is 1,2-ND (least protective) $<1,4-\mathrm{ND}<<\mathrm{DPND}<2,3-\mathrm{ND} \approx 1,8-\mathrm{ND}<<$ EGCG (most protective). This is inversely related to the cytotoxicity (measured by $\mathrm{EC}_{50}$, 
Table 4.1), which gives $1,4-\mathrm{ND}$ (most toxic) $>1,2-\mathrm{ND}>$ DPND $>2,3-\mathrm{ND} \approx 1,8-\mathrm{ND}>$ EGCG. The only inversion is that $1,4-\mathrm{ND}$ is observed to be more cytotoxic than 1,2-ND but simultaneously offers better protection, although over a very narrow range of concentrations (Fig 2). Similarly, an antioxidant effect has been shown for the related molecule menadiol (2-methyl-1,4-naphthalenediol) [33], which is the reduced form of the known oxidative stressor menadione [2]. Thus, even strongly cytotoxic pro-oxidants can also be cytoprotective antioxidants.

The order of cytotoxicity is also supported by the measurements of hydrogen peroxide. As shown in Figure 4.3, the naphthalenediols were incubated with cells and the $\mathrm{H}_{2} \mathrm{O}_{2}$ generated was monitored as a function of time (for $2 \mathrm{~h}$ ). The maximum rate of generation of $\mathrm{H}_{2} \mathrm{O}_{2}$ was observed with the most toxic compounds which undergo redox cycling: $1,4-\mathrm{ND}\left(\mathrm{EC}_{50}=15 \mu \mathrm{M}\right)$, followed by 1,2-ND $\left(\mathrm{EC}_{50}=40 \mu \mathrm{M}\right) .2,3-\mathrm{ND}, \mathrm{DPND}$ and 1,8-ND caused no production of $\mathrm{H}_{2} \mathrm{O}_{2}$. 
Table 4.2. Cytoprotective efficacy of antioxidants against oxidative stress induced by $12 \mathrm{mM} \mathrm{AAPH.}$ Incubation time: $24 \mathrm{~h}, 2 \mathrm{~h}$ pretreatment with antioxidant.

\begin{tabular}{|l|l|l|l|l|}
\hline Compound & $\begin{array}{l}\text { Range }^{\text {a }} \\
(\mu \mathrm{M})\end{array}$ & $\begin{array}{l}\text { Peak Max. } \\
(\% \text { Control })\end{array}$ & $(\% \text { Control } \cdot \mu \mathrm{M})^{\mathbf{b}}$ & $\begin{array}{l}\mathbf{C P A}_{100} \\
(\% \text { Control } \cdot \mu M)^{\mathbf{c}}\end{array}$ \\
\hline 1,2-ND & $5-10$ & 53 & ca. 100 & ca. 100 \\
\hline 1,4-ND & $3-17$ & $70 @ 5 \mu \mathrm{M}$ & $285 \pm 20$ & $285 \pm 20$ \\
\hline DPND & $15-180$ & $56 @ 30 \mu \mathrm{M}$ & $2770 \pm 90$ & $1440 \pm 60$ \\
\hline 2,3-ND & $1-360$ & $96 @ 50 \mu \mathrm{M}$ & $7225 \pm 293$ & $2895 \pm 20$ \\
\hline 1,8-ND & $1-350$ & $100 @ 20 \mu \mathrm{M}$ & $9030 \pm 200$ & $4600 \pm 72$ \\
\hline EGCG & $5-575$ & $100 @ 60 \mu \mathrm{M}$ & $17,300 \pm 1240$ & $4967 \pm 159$ \\
\hline
\end{tabular}

"Total protective range; only the region above "Stress" is counted (see Figure 4.6). ${ }^{\mathrm{b}} \mathrm{CPA}=$ Cytoprotective Area (total)

${ }^{\mathrm{c}} \mathrm{CPA}_{100}=$ Cytoprotective Area with cutoff at $100 \mu \mathrm{M}$ concentration of compound 
In general, it is easy to see from Figure 6 that a very cytotoxic compound cannot be very cytoprotective, hence the approximate inverse order of cytotoxicity $\left(\mathrm{EC}_{50}\right)$ and CPA. This is true regardless of how cytoprotective a compound is at low concentration (triangles, Figure 4.6), the CPA is mostly determined by the cytotoxicity "envelope" (circles, Figure 6). Hence, 1,8-ND and 2,3-ND have too steep a downward slope in their cytotoxicity envelope to be able to compete with EGCG, which has the best CPA by a factor of two. However, this suggests what to consider when cytoprotection is desired and some cytotoxicity can be tolerated. It is more useful (larger increase in CPA) to lower the toxicity of $1,8-\mathrm{ND}$ by appropriate functional group substitutions than it is to try to increase antioxidant activity.

Another possibility for comparing efficacy of compounds is that one may wish to limit the maximum value of concentration to be administered, e.g. $100 \mu \mathrm{M}, 250 \mu \mathrm{M}$, etc. In that case, the CPA can be modified so as to introduce a cutoff on the concentration axis. Table 4.2 shows the recalculated area where the CPA is limited to the range $0-100$ $\mu \mathrm{M}$, denoted $\mathrm{CPA}_{100}$. The order stays the same with one exception; 1,8-ND and EGCG are now essentially equivalent, whereas based on the total CPA EGCG was superior by almost a factor of two.

\section{Reaction mechanism: BDE and Redox Potential}

A discussion of the parameters which are important in determining the relevant reaction mechanisms would normally begin with the redox potential. In this chapter, I have not measured redox potentials for reduction of the naphthoquinones and the naphthosemiquinones. However, we and others have shown that there is a strong 
correlation between gas-phase BDEs (which are easy to calculate) and solution-phase redox potentials, so that weaker $\mathrm{O}-\mathrm{H}$ bonds correspond to more negative redox potentials. An earlier paper on O-H BDEs showed the BDE (gas) and $E^{0}$ (water) are related by 24 kcal mol ${ }^{-1} \mathrm{~V}^{-1}$, with a correlation coefficient of 0.997 [27]. Thus, BDE 2 for 1,4-ND and 2,3-ND (Table 1) differ by $29 \mathrm{kcal} \mathrm{mol}^{-1}$, i.e. by more than a full volt. Next, let us examine some calculated parameters which may explain the observed order, both of cytotoxicity and cytoprotective area.

Figure 4.19 shows the structural changes and BDEs involved in going from diol to quinone. The relevant effects include the presence of hydrogen bonding in parent or semiquinone, interaction of adjacent carbonyl groups, and aromaticity or the lack thereof in the adjacent benzene ring. For catechols, the H-bonding between adjacent $\mathrm{OH}$ groups amounts to ca. $4 \mathrm{kcal} \mathrm{mol}^{-1}$ [34] whereas for its semiquinone the $\mathrm{H}$-bond is much stronger at $8 \mathrm{kcal} \mathrm{mol}{ }^{-1}$; the effects are similar in the naphthalenediols. We estimate the repulsion due to adjacent carbonyl groups to be $5 \mathrm{kcal} \mathrm{mol}^{-1}$ [35]. Now 1,2-ND has a very low $\mathrm{BDE}_{1}=70 \mathrm{kcal} \mathrm{mol}^{-1}$ due to $\mathrm{H}$-bonding in the semiquinone, suggesting an active antioxidant. The corresponding 1,2-NQ has adjacent carbonyl repulsions (destabilizing) but maintains aromaticity in the second ring (stabilizing); the result is a relatively stable quinone leading to a low $\mathrm{BDE}_{2}\left(69 \mathrm{kcal} \mathrm{mol}^{-1}\right)$, which is similar to $\mathrm{BDE}_{1}$. The $1,4-\mathrm{ND}$ is missing the $\mathrm{H}$-bond stabilization in the semiquinone and, as a consequence, the $\mathrm{BDE}_{1}$ rises to $75 \mathrm{kcal} \mathrm{mol}^{-1}$. However, its quinone maintains aromaticity in one ring while losing the adjacent carbonyl repulsions; both effects are stabilizing. As a result, the 1,4$\mathrm{NQ}$ is very stable and $\mathrm{BDE}_{2}$ has the remarkably low value of $55 \mathrm{kcal} \mathrm{mol}^{-1}$. 
The semiquinone of 2,3-ND is stabilized by H-bonding, whereas, in the quinone, the aromaticity in the second ring is lost (no benzene resonance structure can be drawn [10]). The quinone also contains adjacent carbonyl repulsions. The result is a relatively unstable quinone with a high $\mathrm{BDE}_{2}$ of $84 \mathrm{kcal} \mathrm{mol}^{-1}$. This effect is exaggerated in the dipropyl version DPND, where the electron-donating alkyl groups lower $\mathrm{BDE}_{1}$ to $75 \mathrm{kcal}$ $\mathrm{mol}^{-1}$ but increase $\mathrm{BDE}_{2}$ to $86 \mathrm{kcal} \mathrm{mol}^{-1}$. Thus DPND should be more cytoprotective and less cytotoxic than 2,3-ND, although the more lipophilic character of DPND (see Table 4.1) could easily outweigh these small BDE differences.

For $1,8-\mathrm{ND}$, very strong $\mathrm{H}$-bonding in the semiquinone stabilizes it and leads to a low $\mathrm{BDE}_{1}$ of $72 \mathrm{kcal} \mathrm{mol}^{-1}$. However, in this case no quinone is possible and the lowest energy form is the triplet diradical. Loss of a closed-shell structure requires a very large energy penalty to form the diradical; the result is that $\mathrm{BDE}_{2}$ is $104 \mathrm{kcal} \mathrm{mol}^{-1}$, so that this high-energy structure will not form under biological conditions (see also ref. 18).

For EGCG, the weakest $\mathrm{OH}$ bond is in the B-ring at the center position among the three hydroxyl groups. The para-methylpyrogallol subunit provides a close model for $\mathrm{BDE}$ calculations, giving the low $\mathrm{BDE}_{1}=71 \mathrm{kcal} \mathrm{mol}^{-1}$, due to strong $\mathrm{H}$-bonding by the two ortho-OH groups which stabilize the semiquinone. The quinone is slightly destabilized by the adjacent carbonyl groups, causing an increase in $\mathrm{BDE}_{2}$ to $74 \mathrm{kcal}^{\mathrm{mol}}{ }^{-}$ 1. At this point oxidation usually stops. Figure 7 illustrates this in that the BDE for loss of the third $\mathrm{H}$-atom has increased to $85 \mathrm{kcal} \mathrm{mol}^{-1}$. Since the 2,3-ND has a BDE of 84 $\mathrm{kcal} \mathrm{mol}^{-1}$, and is not observed to form, we expect that the quinone form of EGCG (labeled EGCG Quinone in Figure 4.7) will not oxidize to its corresponding radical. 


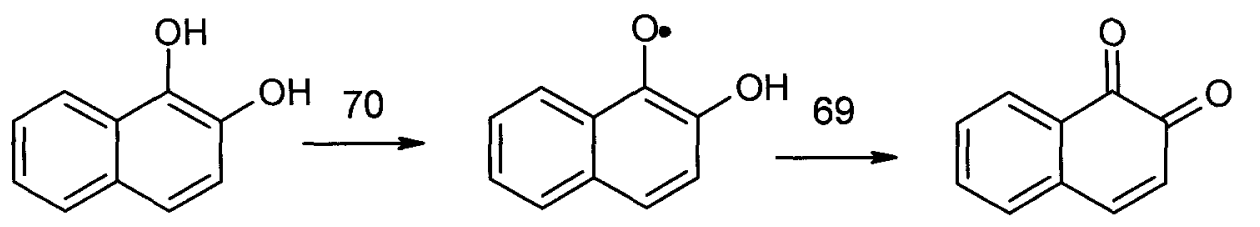

1,2-naphthalenediol

1,2-naphthoquinone<smiles>CC(C)(C)c1ccc(O)c2ccccc12</smiles>

1,4-naphthalenediol

1,4-naphthoquinone<smiles>Oc1cc2ccccc2cc1O</smiles><smiles>Oc1cc2ccccc2cc1O</smiles><smiles>O=C1C=c2ccccc2=CC1=O</smiles>

2,3-naphthalenediol

2,3-naphthoquinone<smiles>Oc1cccc2cccc(O)c12</smiles><smiles>Oc1cccc2cccc(Cl)c12</smiles>

104<smiles>[O-]c1cccc2cccc([O-])c12</smiles>

1,8-naphthalenediol triplet diradical

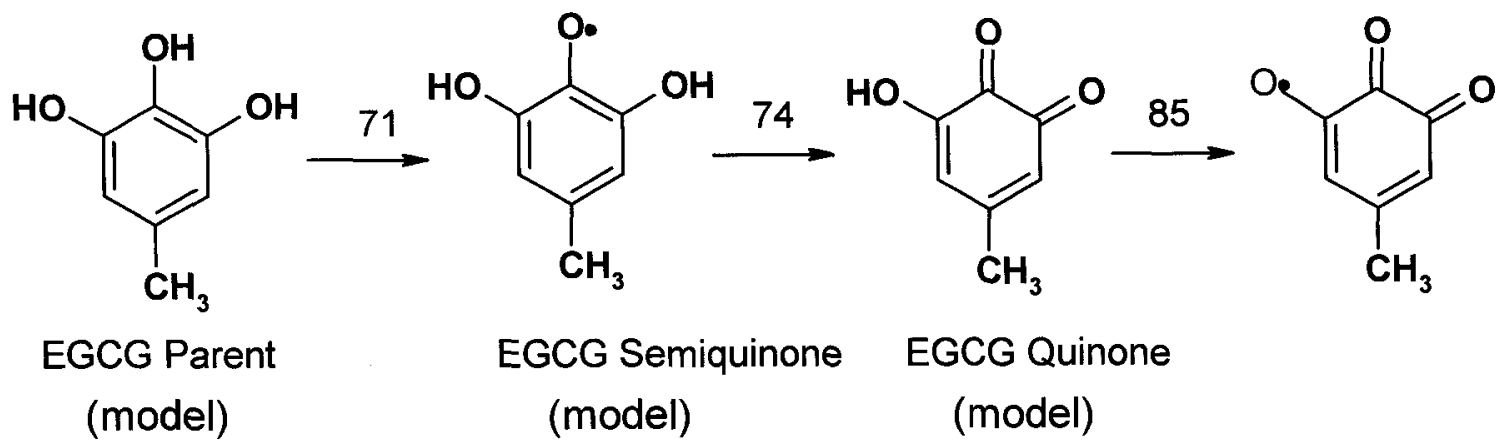

Figure 4.19. Energetics and structural changes for the naphthalenediol $\rightarrow$ naphthosemiquinone $\rightarrow$ naphthoquinone. All BDEs are in $\mathrm{kcal} \mathrm{mol}^{-1}$. 
As discussed above, the antioxidant activity and hence cytoprotection is related to $\mathrm{BDE}_{1}$, whereas a lower $\mathrm{BDE}_{1}$ gives a more active antioxidant [1]. However, $\mathrm{BDE}_{2}$ is related to cytotoxicity since it relates to ease of quinone formation, following which both thiol alkylation or redox cycling can occur. Based on $\mathrm{BDE}_{2}$, I predicted the following order for cytotoxicity: 1,4-ND > 1,2-ND $>$ EGCG $>2,3-\mathrm{ND}>$ DPND $>1,8-\mathrm{ND}$. This ordering is correct with one major exception (EGCG) and one minor exception (DPND is more cytotoxic than 2,3-ND). Also, 1,8-ND would be expected to be even less cytotoxic than observed. The discrepancy regarding 2,3-ND vs. DPND probably is related to the fact that DPND is far more lipophilic (Table 4.1), and more lipophilic molecules tend to be more cytotoxic [5].

The result for EGCG is interesting in that Figure 2 shows that it is clearly the least cytotoxic of all molecules tested. It appears that there is a general lack of toxicity in a 1,2,3-trihydroxybenzene moiety which has been oxidized to the 3-hydroxy-1,2orthoquinone. The reason is that the remaining hydrogen is relatively acidic, with an estimated $\mathrm{pK}_{\mathrm{a}}$ of 6.24 [29], so that the anionic form will predominate at $\mathrm{pH} \mathrm{7.4.} \mathrm{The}$ situation is similar to that in 2-hydroxy-1,4-naphthoquinone, which has been discussed previously [36-37]. This latter compound has been shown not to be a redox cycler in vitro, as well as being a poor electrophile. Here the hydroxynaphthoquinone has a very low $\mathrm{pK}_{\mathfrak{a}}$ of 4.03 , so that the anionic form will be present and will retard both Michael addition (ring is no longer electrophilic) and redox cycling (difficult for a reductase enzyme to reduce an already negative ion) [38]. The same arguments apply to EGCG and its model compound. However, toxicity results can sometimes be quite different in 
vivo, where other reducing enzymes may be present [39] and which can initiate redox cycling.

As shown in Figure 4.7, the cytoprotection area (CPA) is related both to its protective effect and its toxicity envelope. Basing the protective effect on $\mathrm{BDE}_{1}$ alone, I predict an order of protection which is $1,2-\mathrm{ND}>\mathrm{EGCG}>1,8-\mathrm{ND}>1,4-\mathrm{ND}=\mathrm{DPND}>$ 2,3-ND. However, the CPA gives the order EGCG $>1,8-\mathrm{ND}>2,3-\mathrm{ND}>\mathrm{DPND}>1,4-$ $\mathrm{ND}>1,2-\mathrm{ND}$ so $\mathrm{BDE}_{1}$ is not a useful descriptor of cytoprotection. Clearly the reason for this is that the cytotoxicity, which provides the upper envelope for the CPA, is far more important in determining the CPA.

Another factor which can be relevant is the $\mathrm{pK}_{\mathrm{a}}$ of the parent naphthalenediol. Table 1 shows that 5 out of 6 compounds have $\mathrm{pK}_{\mathrm{a}}$ values between $8.2-10.3$, so that the parent (protonated) diol is dominant over its anion at physiological pH. However, 1,8ND has a low $\mathrm{pK}_{\mathrm{a}}$ calculated to be 6.36 [29]. This can increase toxicity if the reduction of oxygen is spontaneous according to $\mathrm{NQH}^{-}+\mathrm{O}_{2} \rightarrow \mathrm{NQH}^{\bullet}+\mathrm{O}_{2}^{\bullet-}$, i.e. the anion becomes a superoxide generator [40]. Finally, even though 1,8-ND and 2,3-ND have only one exchangeable hydrogen atom (or one electron), they still act as a more lipophilic phenol, and phenols have their own inherent cytotoxicity [41].

\section{Effect of added ascorbate on toxicity correlates with BDE value}

As discussed in Results section and can be seen in Table 3, ascorbate is protective (decreases cytotoxicity) in the case of 2,3-ND and DPND, but increases the cytotoxicity of 1,2-ND or doesn't have any effect on the cytotoxicity of 1,4-ND and 1,8-ND. How can I explain the difference? It would be expected that by adding ascorbate, the toxicity 
of naphthalenediols decreases in a cellular environment due to reduction of semiquinone with the regeneration of the catechol and formation of the ascorbate radical anion Asce(reaction 1).

$$
\mathrm{QH}^{\bullet}+\mathrm{AscH}^{-} \rightarrow \mathrm{QH}_{2}+\mathrm{Asc}^{\bullet-}
$$

In this way, the quinone formation is prevented and this reaction is protective. The ascorbate radical anion is dismutated spontaneous or enzymatically into $\mathrm{AscH}^{-}+\mathrm{DHA}^{-}$ [42]. The BDE for $\mathrm{AscH}^{-} \rightarrow \mathrm{Asc}^{\bullet-}+\mathrm{H}$ is $68.5 \mathrm{kcal} \mathrm{mol}^{-1}$. Therefore $\mathrm{AscH}^{-}$can reduce anything whose radical has a BDE above this with a reaction rate that is depending on how high the BDE is. In the case of all naphthalenediols, the $\mathrm{BDE}_{1}$ is higher than 68.5 $\mathrm{kcal} \mathrm{mol}^{-1}$, thus ascorbate should have a protective effect by decreasing their toxicity. However, the effect of ascorbate is also strongly correlated with $\mathrm{BDE}_{2}$.

Ascorbate anion, $\mathrm{AscH}^{-}$, can play a parallel role by reducing the quinone according to the electron-transfer reaction [43].

$$
\mathrm{Q}+\mathrm{AscH}^{-} \rightarrow \mathrm{Q}^{\bullet-}+\mathrm{AscH}^{\bullet}
$$

Alternatively, ascorbate can act by $\mathrm{H}$-atom transfer to give

$$
\mathrm{Q}+\mathrm{AscH}^{-} \rightarrow \mathrm{QH}^{\bullet}+\mathrm{Asc}^{\bullet}
$$

Scheme 4.1 shows the case of $1,4-\mathrm{ND}$ where the $\mathrm{QH}_{2}$ is regenerated quickly $\left(\mathrm{BDE}_{1} \gg\right.$ 68.5) but at the same, time the reaction of forming quinone is very fast ( $\mathrm{BDE}_{2}$ is very low; only $55 \mathrm{kcal} \mathrm{mol}^{-1}$ ). Ascorbate can also reduce the quinone to semiquinone. Overall these two effects are annulled and the ascorbate does not change the cytotoxicity of 1,4$\mathrm{ND}\left(\mathrm{EC}_{50}=14 \pm 0.6 \mu \mathrm{M}\right)$. 


\section{SCHEME 4.1.}

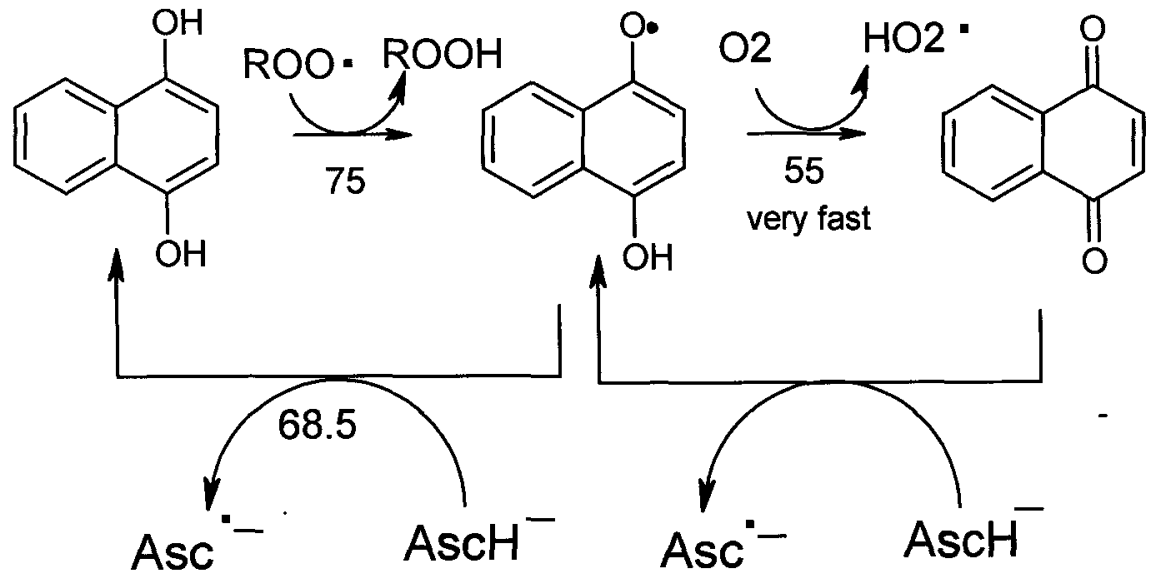

Ascorbate lowers the toxicity of 1,2-ND. Scheme 4.2 shows the regeneration of semiquinone by ascorbate; a very slow process. However, the formation of quinone is very fast due to a low $\mathrm{BDE}_{2}$ leading to a higher toxicity of 1,2-ND when ascorbate is added. Thus ascorbate radical anion, which is normally non-toxic, acts as a pro-oxidant through conversion of the semiquinone into the quinone.

\section{SCHEME 4.2.}
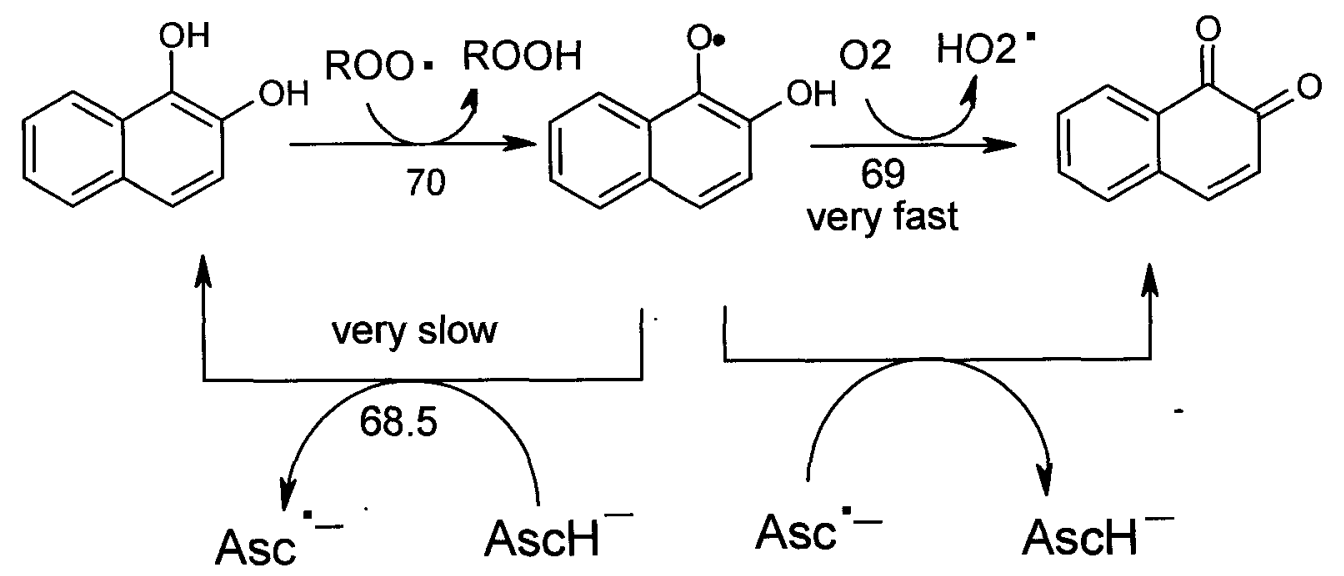

In the case of 1,8-ND, 2,3-ND and DPND, the effect of ascorbate on the toxicity depend only of $\mathrm{BDE}_{1}$ because these naphthalenediols don't form quinones and reaction 2 
does not take place. Thus, ascorbate had a protective effect in the case of 2,3-ND and DPND $\left(\mathrm{BDE}_{1} \gg\right.$ ascorbate $\mathrm{BDE}$ of $\left.68.5 \mathrm{kcal} \mathrm{mol}^{-1}\right)$, respectively. $\mathrm{AscH}^{-}$reduces the semiquinone very fast and the hydroquinone is regenerated by ascorbate. Therefore, the cytotoxicity is decreased. The $\mathrm{BDE}_{1}$ of $1,8-\mathrm{ND}$ is $70 \mathrm{kcal} \mathrm{mol}^{-1}\left(\sim 68.5 \mathrm{kcal} \mathrm{mol}^{-1}\right.$ with ascorbate), therefore the regeneration of hydroquinone by ascorbate is very slow and will not result in any change in toxicity of $1,8-\mathrm{ND}$ with or without ascorbate.

\section{Cytotoxicity and cytoprotection of substituted 1,8 - naphthalenediol}

1,8-ND-DA showed good activity in scavenging peroxyl radicals, while having toxicity comparable to that of naturally occurring polyphenols. This moved us to design and test new substituted 1,8-NDs with a water-solubility higher than 1,8-ND.

The cytotoxicity of the 1,8-ND analogues is the same as 1,8-ND-DA $\left(\mathrm{EC}_{50}>200 \mu \mathrm{M}\right)$ with the exception of 1,8-ND acrylamide with an $\mathrm{EC}_{50}>350 \mu \mathrm{M}$. Table 4.3 shows the result of treating each 1,8-ND analogues in the same way as 1,8-ND-DA. The CPA order for the 1,8-ND derivatives is 1,8-ND DGly (least protective) $<1,8-\mathrm{ND}$ acrylate $<1,8-\mathrm{ND}$ acrylamide $<1,8-\mathrm{ND}$ (most protective). The same order is also obtained for CPA $\mathrm{C}_{100}$. 
Table 4.3. $\mathrm{EC}_{50}$ and cytoprotective efficacy of substituted 1,8-NDs against oxidative stress induced by $12 \mathrm{mM}$ AAPH. Incubation time: $24 \mathrm{~h}, 2 \mathrm{~h}$ pretreatment with antioxidant.

\begin{tabular}{|c|c|c|c|c|c|c|}
\hline Compound & $\begin{array}{l}\mathrm{EC}_{50} \\
(\mu \mathrm{M})\end{array}$ & $\log P^{a}$ & $\begin{array}{c}\text { Range }^{\mathbf{b}} \\
(\boldsymbol{\mu M})\end{array}$ & $\begin{array}{l}\text { Peak Max. } \\
\text { (\% Control) }\end{array}$ & $\begin{array}{c}\text { CPA } \\
(\% \text { Control } \bullet \mu \mathrm{M})^{\mathrm{c}}\end{array}$ & $\begin{array}{c}\mathrm{CPA}_{100} \\
(\% \text { Control } \bullet \mu \mathrm{M})^{\mathrm{d}}\end{array}$ \\
\hline 1,8-ND & 250 & 2.2 & $10-350$ & $100 @ 20 \mu \mathrm{M}$ & $9030 \pm 200$ & $4600 \pm 20$ \\
\hline 1,8-ND-DA acrylate & 220 & 2.54 & $10-300$ & $83 @ 80$ & $6643 \pm 460$ & $2790 \pm 140$ \\
\hline $\begin{array}{l}1,8-N D-D A \\
\text { acrylamide }\end{array}$ & $>350$ & 1.62 & $10-300$ & $89 @ 60$ & $7119 \pm 146$ & $2989 \pm 113$ \\
\hline 1,8-ND DGly & 240 & 0.08 & $10-350$ & $75 @ 50$ & $4700 \pm 85$ & $2255 \pm 47$ \\
\hline
\end{tabular}

${ }^{a} \log \mathrm{P}$ was calculated using the Spartan '02 program.

"Total protective range; only the region above "Stress" is counted (see Figure 4.14).

${ }^{\mathrm{c}} \mathrm{CPA}=$ Cytoprotective Area (total)

${ }^{\mathrm{d}} \mathrm{CPA}_{100}=$ Cytoprotective Area with cutoff at $100 \mu \mathrm{M}$ concentration of compound 
It is very important in evaluating the efficacy of an antioxidant in cells to know the ability of the antioxidant to penetrate into the cells. The more lipophilic a compound, the better it can penetrate lipid membrane. A very interesting case is 1,8-ND-DA acrylamide that showed a very low toxicity (comparable to that of EGCG $(>350 \mu \mathrm{M})$ ) but an unexpected cytoprotection. As can be seen in Figure 4.17 the toxicity envelope does not define the CPA of 1,8-ND-DA acrylamide. There are two mechanisms in order to explain this trend. First, is that the 1,8-ND-DA acrylamide is too water-soluble and does not cross a hydrophobic membrane readily. The calculated Log $\mathrm{P}$ for $1,8-\mathrm{ND}-\mathrm{DA}$ and 1,8-ND-DA-acrylamide (Table 4.3) are 2.25 and 1.67, respectively. A very significant change in solubility is due to the added acrylamide group and 1,8-ND acrylamide is therefore much more water-soluble than $1,8-\mathrm{ND}$. Thus, its actual concentration inside the cell is lower than expected and explains the lower toxicity as well as the lower protection compared to 1,8-ND. The second mechanism could be explained based on the difference in $\mathrm{pK}_{\mathrm{a}}$ of the naphthalenediols. The compounds pass through the PC12-AC cell membrane and are hydrolyzed by intracellular esterase forming the corresponding diols. In the case of 1,8-naphthalenediol, the $\mathrm{pK}_{\mathrm{a}}$ is very low (6.3) compared with $\mathrm{pK}_{\mathrm{a}}$ of other 1,8-ND derivatives and so its anion form is dominant over its parent (protonated) diol at physiological $\mathrm{pH}$. Therefore, 1,8-naphthalenediol is leaking outside the cell very slowly and in this way it mainly acts inside the cell protecting the cells against intracellular oxidative stress induced by peroxyl radicals. 


\subsection{CONCLUSION}

The results described here suggest some considerations in antioxidant design for compounds with two exchangeable hydrogens. To maximize the cytoprotective area, it is useful to (i) keep $\mathrm{BDE}_{1}$ relatively low to increase cytoprotection, (ii) keep $\mathrm{BDE}_{2}$ high to minimize cytotoxicity, (iii) avoid high lipophilicity which may increase toxicity (unless a lipophilic antioxidant is the target), (iv) avoid low $\mathrm{pK}_{\mathrm{a}}$ 's for the parent compound which can lead to superoxide production, and (v) try to use acidity as an advantage (as in the hydroxyquinone of EGCG). I have made some progress in carrying out such a synthetic program using a variety of substituted naphthalenediols.

\subsection{REFERENCES}

1. Foti, M. C., Johnson, E. R., Vinqvist, M. R., Wright, J. S., Barclay, L. R. C., and Ingold, K. U. (2002) Naphthalene diols: a new class of antioxidants. Intramolecular hydrogen bonding in catechols, naphthalene diols and their aryloxyl radicals. J. Org. Chem. 67, 5190-5196.

2. Hussain, H. H., Babic, G., Durst, T., Wright, J. S., Flueraru, M., Chichirau, A., and Chepelev, L. L. (2003) Development of Novel Antioxidants: design, synthesis and reactivity. J. Org. Chem. 68, 7023-7032.

3. Chichirau, A., Flueraru, M., Chepelev, L.L., Wright, J.S., Willmore, W.G., Durst, T., Hussain, H.H., and Charron, M. (2005) Mechanism of cytotoxicity of catechols and a naphthalenediol in PC12-AC cells: the connection between extracellular autoxidation and molecular electronic structure. Free Rad. Biol. Med. 38, 344-355. 
4. Brunmark, A., and Cadenas, E. (1989) Redox and addition chemistry of quinoid compounds and its biological implications. Free Rad. Biol. Med. 7, 435-477.

5. O'Brien, P. J. (1991) Molecular mechanisms of quinone toxicity. Chem. Biol. Interact. $80,1-41$.

6. Monks, T.J., Hanzlik, R. P., Cohen, G. M., Ross, D., and Graham, D. G. (1992) Contemporary issues in toxicology: Quinone chemistry and toxicity. Toxicol. Appl. Pharmacol. 112, 2-16.

7. Miller, M. G., Rodgers, A., and Cohen, G. M. (1986) Mechanisms of toxicity of naphthoquinones to isolated hepatocytes. Biochem. Pharmacol. 35, 1177-1184.

8. Gant, T. W., Rao, D. N., Mason, R. P., and Cohen, G. M. (1988) Redox cycling and sulphydryl arylation: Their relative importance in the mechanism of quinone cytotoxicity to isolated hepatocytes. Chem Biol. Inter. 65, 157-173.

9. Verma, R. P., and Hansch, C. (2004) Elucidation of structure-activity relationships for 2-or 6-substituted-5,8-dimethoxy-1,4-naphthoquinones. Biorg. Med. Chem. 12, 59976009.

10. Munday, R. (2000) Autoxidation of naphthohydroquinones: Effects of $\mathrm{pH}$, naphthoquinones and superoxide dismutase. Free Rad. Res. 32, 245-253.

11. Sarabia S. F., Zhu, B. T., Kurosawa, T., Tohma, M., and Liehr, J. G. (1997) Mechanism of cytochrome P450-catalyzed aromatic hydroxylation of estrogens. Chem. Res. Toxicol. 10, 767-71.

12. Zhang, F., Chen, Y., Pisha, E., Shen, L., Xiong, Y., van Breemen, R. B., and Bolton, J. L. (1999) The major metabolite of equilin, 4-hydroxyequilin, autoxidizes to an o- 
quinone which isomerizes to the potent cytotoxin 4-hydroxyequilenin-o-quinone. Chem. Res. Toxicol. 12, 204-213.

13. Gleicher, Gerald J., Church, Daniel F., and Arnold, James C. (1974) Calculations on quinonoid compounds. II. Ground-state properties of quinones. J. Am. Chem Soc. 96, 2403-2409.

14. Scott, L. T., Rozeboom, M. D., Houk, K. N., Fukunaga, T.P., Lindner, H. J., and Hafner, K. (1980) The quinones of azulene. A theoretical prognosis. J. Am. Chem Soc. $102,5169-5176$.

15. Samuni,A. M., Chuang, E. Y., Krishna, M. C., Stein, W., DeGraff, W., Russo, A.; and Mitchell, J. B. (2003) Semiquinone radical intermediate in catecholic estrogenmediated cytotoxicity and mutagenesis: Chemoprevention strategies with antioxidants. Proc. Natl. Acad. Sci. USA. 100, 5390-5395.

16. Morita, K., Arimochi, H., and Ohnishi, Y. (2003) In vitro cytotoxicity of 4methylcatechol in murine tumor cells: Induction of apoptotic cell death by extracellular pro-oxidant action. J. Pharmacol. Exp. Ther. 306, 317-323.

17. Clement, V., Long, L. H., Ramalingam, J., and Halliwell, B. (2002) The cytotoxicity of dopamine may be an artefact of cell culture. J. Neurochem. 81, 414-421.

18. Watanabe, N., and Forman, H. J. (2003) Autoxidation of extracellular hydroquinones is a causative event for the cytotoxicity of menadione and DMNQ in A549-S cells. Arch. Biochem. Biophys. 411, 145-157.

19. Greene L.A., Aletta J. M., Rukenstein A., and Green S.H. (1987) PC12 pheochromocytoma cells: culture, nerve growth factor treatment, and experimental exploitation. Methods Enzymol. 147, 207-216. 
20. Platt, K. L., and Oesch, F. (1983) Efficient synthesis of non-K-region transdihydrodiols of polycyclic aromatic hydrocarbons from o-quinones and catechols. $J$. Org. Chem. 48, 265-268.

21. Ragot, J. P., Steeneck, C., Alcaraz, M.-L., and Taylor, R. J. K. (1999) The synthesis of 1,8-dihydroxynaphthalene-derived natural products: palmarumycin $\mathrm{CP} 1$, palmarumycin $\mathrm{CP} 2$, palmarumycin $\mathrm{C} 11, \mathrm{CJ}-12,371$, deoxypreussomerin $\mathrm{A}$ and novel analogs. Perkin Trans. 1 8, 1073-1082.

22. Mossmann, T. (1983) Rapid colorimetric assay for cellular growth and survival. Application to proliferation and cytotoxicity assays. J. Immunol. Methods, 65, 55-63.

23. Denizot, F., and Lang, R. (1986) Rapid colorimetric assay for cell growth and survival. modifications to the tetrazolium dye procedure giving improved sensitivity and reliability. J. Immunol. Methods, 89, 271-277.

24. Vistica, D.T., Skehan, P., Scudiero, D., Monks, A., Pittman, A., and Boyd, M. R. (1991) Tetrazolium-based assays for cellular viability: a critical examination of selected parameters affecting formazan production. Cancer Res. 51, 2515-2520.

25. Wolff, S. P. (1993) Ferrous ion oxidation in the presence of ferric ion indicator xylenol orange for measurement of hydroperoxides. Methods Enzymol. 233, 182-189.

26. Terao, K. and Niki, E. (1986) Damage to biological tissues induced by radical initiator 2,2'-azobis(2-amidinopropane) dihydrochloride and its inhibition by chainbreaking antioxidants. Free Rad. Biol. Med. 2, 193-201; 1986.

27. Barclay, L. R. C. (1993) Model biomembranes: quantitative studies of peroxidation, antioxidant action, partitioning and oxidative stress. Can. J. Chem. 71, 1-16. 
28. DiLabio, G. A., Pratt, D. A., LoFaro, A. D., and Wright, J. S. (1999) Theoretical study of X-H bond energetics $(\mathrm{X}=\mathrm{C}, \mathrm{N}, \mathrm{O}, \mathrm{S})$ : Application to substituent effects, gas phase acidities and redox potentials. J. Phys. Chem. A 103, 1653-1661.

29. SciFinder Scholar, American Chemical Society, 2004 edition.

30. Siegel, S. M. and Siegel, B. Z. (1958) Autoxidation of pyrogallol: general characteristics and inhibition by catalase. Nature (London) 181, 1153-1154.

31. Lam, L. K., Garg, P. K., Swanson, S. M., and Pezzuto, J. M. (1988) Evaluation of the cytotoxic potential of catechols and quinones structurally related to butylated hydroxyanisole. J. Pharm. Sci. 77, 393-395.

32. Conte, A., Pellegrini, S., and Tagliazucchi, D. (2003) Synergistic protection of PC12 cells from $\beta$-amyloid toxicity by resveratrol and catechin. Brain Res. Bul. 62, 29-38.

33. Tampo, Y., and Yonaha, M. (1996) Enzymatic and molecular aspects of the antioxidant effect of menadione in hepatic microsomes. Arch. Biochem. Biophys. 334, $163-174$.

34. Wright, J. S., Johnson, E. R., and DiLabio, G. A. (2001) Predicting the activity of phenolic antioxidants: Theoretical method, analysis of substituent effects, and application to major families of antioxidants. J. Am. Chem. Soc. 123, 1173-1183; 2001.

35. Wright, J. S., Rowley, C. N., and Chepelev, L. L. (2005) A 'universal' B3LYP-based method for gas-phase molecular properties: Bond dissociation enthalpy, ionization potential, electron and proton affinity and gas-phase acidity. Mol. Phys. 103, 815-823.

36. Mundy, R., Fowke, E. A., Smith, B. L., and Munday, C. M. (1994) Comparative toxicity of alkyl-1,4-naphthoquinones in rats: Relationship to free radical production in vitro. Free Rad. Biol. Med. 16, 725-731. 
37. Munday, R., Smith. B. L., and Fowke, E. A. (1991) Haemolytic activity and nephrotoxicity of 2-hydroxy-1,4-naphthoquinone in rats. J. Appl. Toxicol. 11, 85-90.

38. Doherty, M. A., Rodgers, A., and Cohen, G. M. (1987) Mechanisms of toxicity of 2and 5-hydroxy-1,4-naphthoquinone; absence of a role for redox cycling in the toxicity of 2-hydroxy-1,4-naphthoquinone to isolated hepatocytes. J. Appl. Toxicol. 7, 123-129.

39. Osman, A. M., and van Noort, P. C. M. (2003) Evidence for redox cycling of lawsone in the presence of the hypoxanthine/xanthine oxidase system. J. Appl. Toxicol. $23,209-212$.

40. Ollinger, K., Buffinton, G. D., Ernster, L., and Cadenas, E. (1990) Effect of superoxide dismutase on the autoxidation of substituted hydro- and seminaphthoquinones. Chem.-Biol. Int. 73, 53-76.

41. Moridani, M. Y., Siraki, A., and O'Brien, P. J. (2003) Quantitative structure toxicity relationships for phenols in isolated rat hepatocytes. Chem. Biol. Int. 145, 213-223.

42. Buettner, L. W. (1993) The pecking order of free radicals and antioxidants: lipid peroxidation, $\alpha$-tocopherol, and ascorbate. Arch. Biochem. Biophy. 300, 535-543.

43. Roginsky, V., Michel, Ch., and Bors, W. (2000) Reactivity of semiquinone with ascorbate and the ascorbate radical as studied by pulse radiolysis. Arch. Biochem. Biophys. 384, 74-80. 


\section{Chapter 5}

\section{Cytotoxicity and cytoprotective activity of}

\section{naphthalenediols in rat cortical neurons}




\subsection{INTRODUCTION}

Current understanding of the causes of neurodegenerative diseases such as Alzheimer's disease (AD), Parkinson's disease (PD) and amyotrophic lateral sclerosis (ALS) indicates that there is probably an oxidative stress component [1,2]. Consequently, dietary antioxidant therapy is being studied as a possible therapeutic approach. A number of studies have examined the protective effects of naturally occurring dietary antioxidants such as Vitamin $\mathrm{C}$ and Vitamin E, glutathione, carotenoids, flavonoids, polyphenols and antioxidant enzymes [3-5]. The experimental data on use of antioxidants in cell cultures and rodent models of neurodegenerative diseases show distinct benefits [5], but the clinical and epidemiological outcomes from human trials seem to be less clear-cut.

By contrast, little work has been done on the systematic design of antioxidants targeted towards reducing age-related neurodegenerative disease, but such "designer antioxidants" are attracting increasing attention now that the principles behind antioxidant design are relatively well understood [6-10]. In previous chapter using adherent PC-12 adrenal cells, I subjected the cells to oxidative stress in the form of AAPH (2,2'-azobis (2-amidinopropane) hydrochloride), which generates a continuous flux of alkylperoxyl radicals [11]. Cytotoxicity studies showed that 1,2naphthalenediol (1,2-ND) and 1,4-ND were quite toxic and were thus ruled out as potentially useful antioxidants. However, 2,3-ND and especially 1,8-ND showed significant cytoprotection against AAPH, while at the same time showing low inherent toxicity. Thus, further studies were indicated for the latter two species.

We rationalized these experimental results with the help of density functional theory (DFT) by calculating, enthalpy changes between the parent naphthalenediol 
(also called naphthohydroquinone, symbolized $\mathrm{NQH}_{2}$ ), the partially oxidized naphthosemiquinone radical $\left(\mathrm{NQH}^{\circ}\right)$ and the fully oxidized naphthoquinone (NQ) $[11,12]$. Calculated bond dissociation enthalpy (BDE) values for $\mathrm{NQH}_{2} \rightarrow \mathrm{NQH}^{\bullet}$ $\left(\mathrm{BDE}_{1}\right)$ and $\mathrm{NQH}^{\circ} \rightarrow \mathrm{NQ}\left(\mathrm{BDE}_{2}\right)$ showed that when $\mathrm{BDE}_{2}$ is low (e.g. $<75 \mathrm{kcal} \mathrm{mol}^{-}$ ${ }^{1}$ ) formation of the quinone product is observed. Quinone formation is generally accompanied by toxicity in the form of redox cycling and subsequent hydrogen peroxide production, or attack on the electrophilic quinone by cellular nucleophiles such as GSH or cysteine-containing proteins [13-15]. This situation holds for 1,2-ND and 1,4-ND; both redox cycling and thiol depletion mechanisms can contribute to the observed cytotoxicity. On the other hand, loss of aromaticity (in the unsubstituted ring) on quinone formation for 2,3-ND exerts a heavy energy penalty preventing their formation. Simple Lewis structures show that no quinone structure can be drawn when starting from 1,8-ND, instead a triplet diradical state is formed. As a result, the 2,3-NQ and 1,8-NQ products were not formed and hence the parent naphthalenediols were much less toxic. They were also shown to be strongly cytoprotective. In the present paper I extend the study of naphthalenediols to primary rat cortical neurons, to see if the conclusions derived from PC-12 cells are more general and to see whether animal trials should be pursued. For comparison, I include the antioxidant (-)epigallocatechin gallate (EGCG), the principal polyphenol present in green tea, which is known to be a superior neuroprotective antioxidant [16-20]. 


\subsection{MATERIALS AND METHODS}

\section{Materials}

The sources of materials, measures of purity etc. are the same as those described previously in chapter 4. It also described the sources from which we obtained 1,2-ND (prepared from its quinone), 1,4-ND, 2,3-ND, 1,8-ND and EGCG. Glutamate, dimethyl sulfoxide (DMSO), glutamine, glucose, Penicillin/Streptomycin and PBS (phosphate buffered saline) were obtained from Sigma Chemical Co. (St. Louis, MO, USA). Neurobasal medium, B-27 serum-free supplement and B-27 supplement Minus AO (antioxidant-free), Minimum Essential Medium (MEM), horse serum and fetal bovine serum, were purchased from Invitrogen (Carlsbad, CA, USA).

\section{Cell culture}

I used two methods to prepare the cell culture of cortical neurons; starting either from animals or from frozen cell stock, respectively.

1. Primary cultures of cortical neurons were obtained from eighteen-day-old pregnant Sprague-Dawley rats (Charles River) following the procedure described previously [21]. All experiments were performed according to the Guidelines of the Canadian Council on Animal Care and approved by the Carleton University Animal Care Committee. In brief, the rats were sacrificed using $\mathrm{CO}_{2}$, pups were removed, transferred to ice-cold PBS and decapitated. Cortices were surgically removed, suspended in $2 \mathrm{~mL}$ plating media consisting of Eagle's minimal essential medium (MEM), supplemented with $10 \%$ horse serum, 10\% fetal bovine serum, $2 \mathrm{mM}$ glutamine and $20 \mathrm{mM}$ glucose, and mechanically dissociated. The cell suspension was centrifuged at $1100 \mathrm{rpm}$ for 6 minutes at $20{ }^{\circ} \mathrm{C}$. After removal of supernatant, the 
resulting pellets were resuspended in $8-10 \mathrm{~mL}$ plating media. Cell viability was determined by the trypan blue exclusion method. The cells were plated in $35 \mathrm{~mm}$ dishes (Corning) previously treated with poly-D-lysine at a concentration of $1.0 \times 10^{6}$ cells/dish. Cultures were maintained in a $5 \% \mathrm{CO}_{2}$ atmosphere at $37{ }^{\circ} \mathrm{C}$. After one week, the medium was replaced with Neurobasal medium containing B-27 supplement. Further media changes occurred bi-weekly.

2. Cryopreserved rat cerebral cortex neuronal cells were a gift from QBM Cell Science Inc., Ottawa, Canada. The cells were thawed, suspended in Neurobasal medium supplemented with B-27, Penicillin $(100 \mathrm{U} / \mathrm{mL}) /$ Streptomycin $(100 \square \mathrm{g} / \mathrm{mL})$ and seeded in 96-well plates coated with poly-D-lysine at a concentration of $3 \times 10^{5}$ cells $/ \mathrm{mL}$. The cells were incubated at $37{ }^{\circ} \mathrm{C}$ in a humidified atmosphere $\left(5 \% \mathrm{CO}_{2}\right.$ in air) for $4 \mathrm{~h}$. Then the medium was removed leaving a small volume to ensure the cells did not dry out and pre-warmed medium was added. For 14 days, $50 \%$ of the medium was replaced with fresh medium twice weekly.

\section{Cytotoxicity test using MTT assay}

Experiments were performed on days 14-16 of cultures. Medium was removed, and the cells were incubated for an additional $24 \mathrm{~h}\left(37{ }^{\circ} \mathrm{C}, 5 \% \mathrm{CO}_{2}\right)$ in Neurobasal medium supplemented with B-27 Minus AO (NB27 - AO) (Invitrogen) [22]. After 24 $h$ the NB27-AO medium was replaced with fresh medium containing NB27 - AO and the compounds to be tested (in DMSO, final DMSO concentration $<0.5 \%$ ) and the incubation was continued for another $24 \mathrm{~h}$. The neuronal cultures were assessed for viability using the MTT assay. Briefly, the cultures were washed with PBS and incubated with medium and $10 \mu \mathrm{L}$ MTT $(5 \mathrm{mg} / \mathrm{mL})$ for $2 \mathrm{~h}$. The cells were then lysed 
in DMSO and the absorbance values were read at $570 \mathrm{~nm}$ with background subtraction at $630 \mathrm{~nm}$. Control consisted of NB27 - AO plus DMSO with no added compound; its absorbance ( 3 measurements) determines cell viability for Control, set at $100 \%$.

\section{Protection against oxidative stress induced by AAPH}

For all cytoprotection experiments the term "medium" refers to NB27 - AO. The 96-well microplates prepared in the same way as before $\left(2 \times 10^{5}\right.$ cells $\left./ \mathrm{mL}\right)$ were incubated in medium for $24 \mathrm{~h}$ prior to use. The cytoprotection was assessed by the method described previously (Material and Methods - Chapter 3). In brief, the cells were incubated with the compounds tested (1-150 $\mu \mathrm{M})$ for $2 \mathrm{~h}$ prior to addition of AAPH (1.5 mM). After $24 \mathrm{~h}$ further incubation with AAPH + compound, the cell viability was assessed using MTT $(5 \mathrm{mg} / \mathrm{mL})$. At $1.5 \mathrm{mM}$, the oxidative stress generated by AAPH reduces the cell viability to ca. $36-40 \%$ that of Control (labeled "Stress" on figures to follow).

\section{Protection against oxidative stress induced by glutamate}

Experiments were performed in dishes on days 14-16 of culture. The maintenance medium was replaced with NB27 - AO. After $24 \mathrm{~h}$ incubation the medium was discarded and replaced with fresh medium containing the compounds at concentrations ranging from $0.1-100 \mu \mathrm{M}$, and incubated for $2 \mathrm{~h}$. Glutamate $(250 \mu \mathrm{M})$ was added to the dishes and the incubation was continued for another $3 \mathrm{~h}$. The cells were washed once with $1 \mathrm{~mL}$ PBS and new medium was added. After $24 \mathrm{~h}$ the cell viability was assessed by the trypan blue exclusion method. The number of dead cells 
was counted under the microscope (PIX Cell II) in 8-10 randomly chosen fields in every dish and was expressed as a percentage of Control ( $0 \mu \mathrm{M}$ glutamate).

\section{Statistics}

Data are expressed as mean $\pm \mathrm{SEM}$ values. In the case of $\mathrm{EC}_{50}$ (see Figure 5.2) and CPA (see Figures 5.5-5.7) the same treatment as described in Chapter 3- statistics was applied in order to calculate the error of the $\mathrm{EC}_{50}$ and $\mathrm{CPA}$, respectively. Statistical significance was assessed by using one-way ANOVA. Differences were considered significant at $p<0.05$.

\section{Calculation of BDE}

The method of calculation of the BDE was previously described [chapter 3] in which relevant BDE values were described for the naphthalenediols and an EGCG model compound. Briefly, the BDE corresponds to the standard gas-phase enthalpy change at $298 \mathrm{~K}\left(\Delta \mathrm{H}^{\circ}{ }_{298}\right)$ for $\mathrm{ArO}-\mathrm{H}(\mathrm{g}) \rightarrow \mathrm{ArO}^{\bullet}(\mathrm{g})+\mathrm{H}^{\bullet}(\mathrm{g})$. In cases where there are two exchangeable $\mathrm{OH}$ groups, $\mathrm{BDE}_{1}$ refers to loss of the first (most weakly bound) $\mathrm{H}$ atom to form the semiquinone, and $\mathrm{BDE}_{2}$ to loss of the second $\mathrm{H}$-atom to form the quinone. Starting geometries, which included conformer searching, were obtained with the Spartan '02 builder module (WaveFunction, Inc., Irvine, CA USA) using the AM1 method; coordinates were then sent to the Gaussian 98 program for subsequent calculations using the lowest-level method (LLM) described by DiLabio et al [23]. 


\subsection{RESULTS}

\section{Experimental}

I first examined the cytotoxicity on primary neuronal cultures of the naphthalenediols prepared in their diacetylated form and well-known compound EGCG. The naphthalenediol diacetates cross the cell membrane and the acetate moieties are cleaved by cellular esterases, forming the diols. Figure 5.1 shows structures for the five compounds tested, where all of the naphthalenediols have been fully acetylated.<smiles>CC(=O)Oc1ccc2ccccc2c1OC(C)=O</smiles>

1,2-ND-DA<smiles>CC(=O)Oc1cc2ccccc2cc1OC(C)=O</smiles>

2,3-ND-DA<smiles>CC(=O)Oc1ccc(OC(C)=O)c2ccccc12</smiles>

1,4-ND-DA<smiles>CC(=O)Oc1cccc2cccc(OC(C)=O)c12</smiles>

1,8-ND-DA<smiles>O=C(O[C@H]1Cc2c(O)cc(O)cc2O[C@H]1c1cc(O)c(O)c(O)c1)c1cc(O)c(O)c(O)c1</smiles>

Figure 5.1. Structural formulas for the 5 compounds tested, where $1,2-\mathrm{ND}-\mathrm{DA}=1,2-$ naphthalenediol diacetate, etc. and EGCG $=(-)$-epigallocatechin gallate. 
Figure 5.2 shows the cell viability vs. concentration of compound for the five compounds tested. Cell Viability is defined here as the percent of live cells (from MTT assay) relative to Control (zero concentration of compound). There is clearly a wide range of cytotoxicity among the compounds tested, ranging from 1,4-ND (most toxic) and $1,2-\mathrm{ND}$ (very toxic) $>>2,3-\mathrm{ND} \approx \mathrm{EGCG} \approx 1,8-\mathrm{ND}$ (relatively non-toxic). Note that EGCG showed reproducible enhancement of survival (cell viability above $100 \%)$.

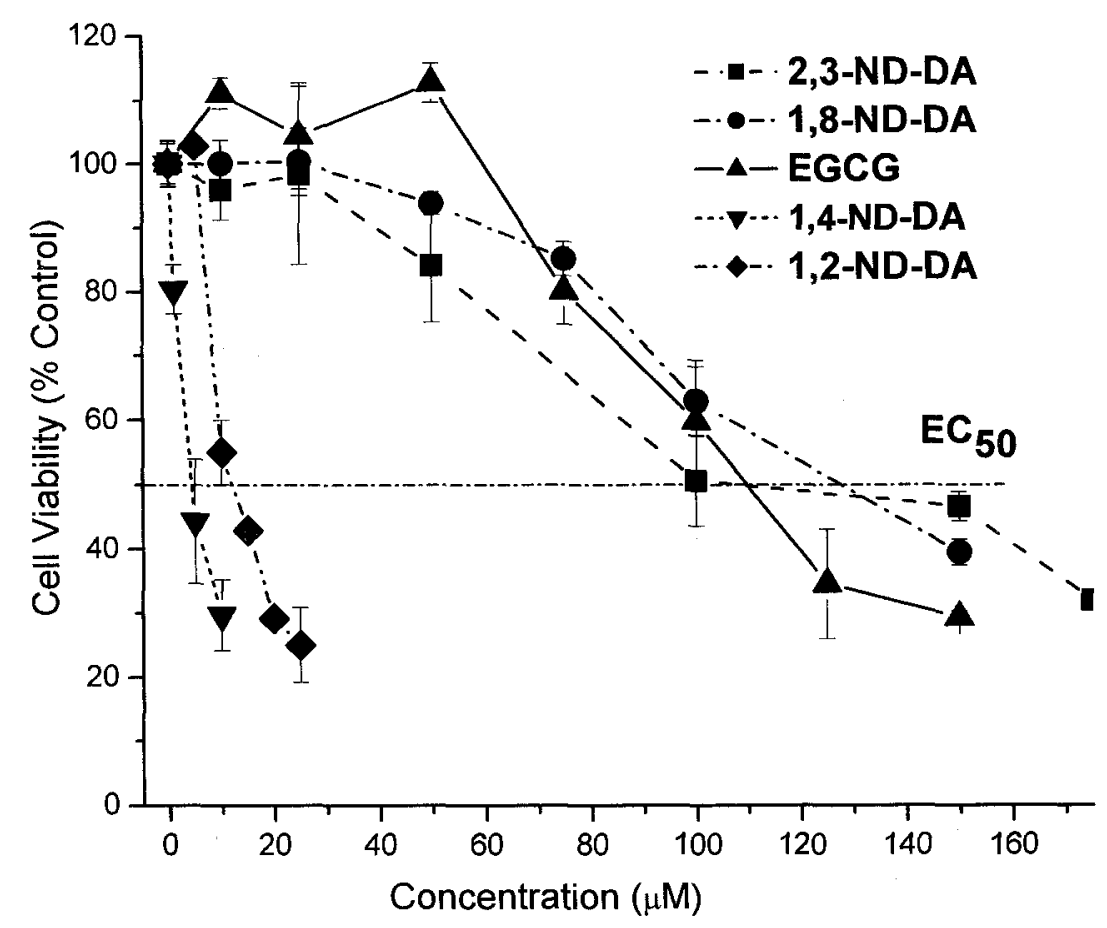

Figure 5.2. Cell viability of rat cortical neurons (MTT assay) after $24 \mathrm{~h}$ incubation with naphthalenediols and EGCG. All compounds except EGCG were initially present as diacetates. 
Figure 5.3 shows the cytotoxicity caused by the oxidative stressor AAPH, which generates peroxyl radicals $\left(\mathrm{ROO}^{\circ}\right)$, at a relatively constant rate. Here $\mathrm{EC}_{50}$ represents the effective concentration which reduces formazan blue absorbance (MTT assay) to $50 \%$ of Control (Control: no AAPH added). Fitting a quadratic function to the data in Figure 5.3 gave an $\mathrm{EC}_{50}$ of $1.23 \pm 0.20 \mathrm{mM}$, with a correlation coefficient $\mathrm{R}^{2}=0.956$

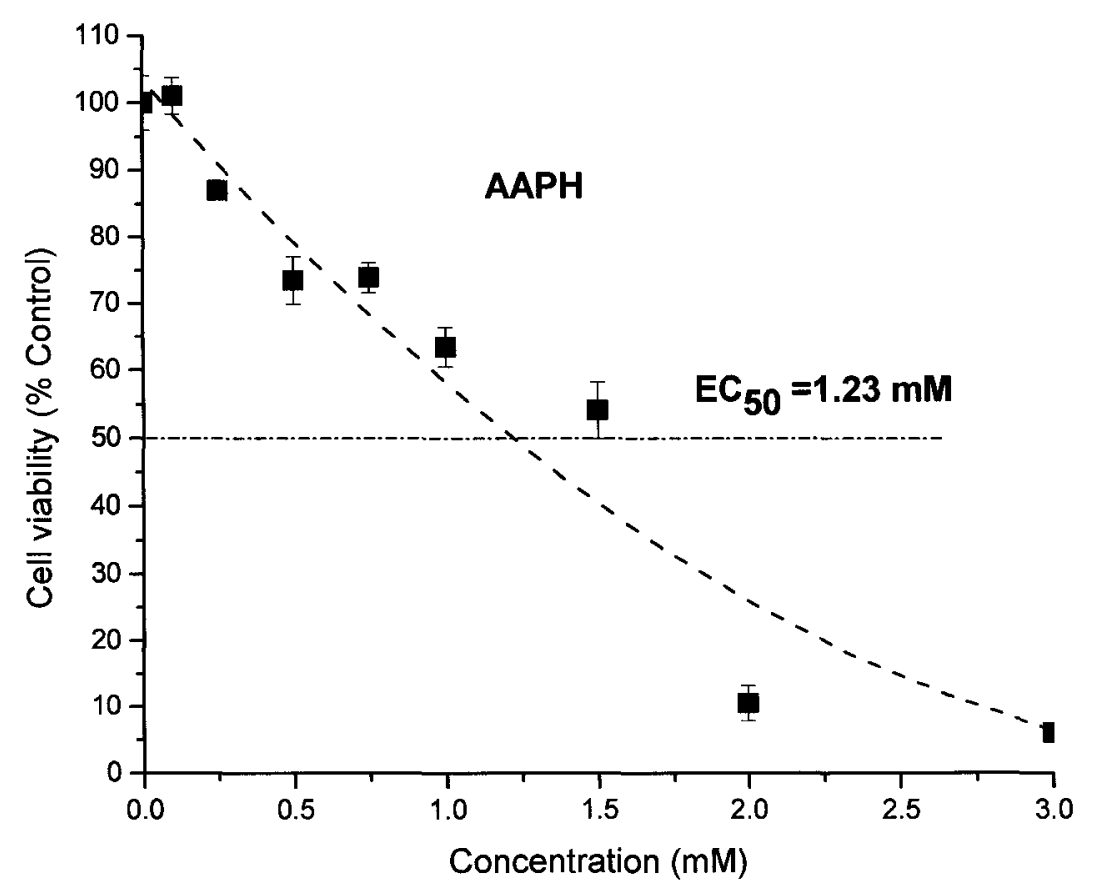

Figure 5.3. Cell viability (MTT assay) for primary cortical neurons vs. concentration of $\mathrm{AAPH}$.

For tests of cytoprotection the relatively toxic 1,2-ND and 1,4-ND were discarded and effort was concentrated on the less-toxic species 2,3-ND, 1,8-ND and the reference compound EGCG. Figure 5.4 shows the cytoprotection resulting from 
the pretreatment of the cells for $2 \mathrm{~h}$ with 1,8-ND-DA, 2,3-ND-DA and EGCG prior to adding AAPH. The AAPH stressor reduced the viability from $100 \%$ (Control) to $38 \%$ (Stress), so any viability above $38 \%$ represents protection of the neurons. The naphthalenediols are protective over the full range tested $(10-150 \mu \mathrm{M})$. whereas EGCG is only protective up to $120 \mu \mathrm{M}$. Comparing the 2,3-ND and 1,8-ND, it can be seen that both compounds behave similarly and are strongly protective over the range shown. The cytoprotection curve for EGCG is more sharply peaked, reaching its maximum of $113 \%$ at $50 \mu \mathrm{M}$, but otherwise showing less protection than the two naphthalenediols.

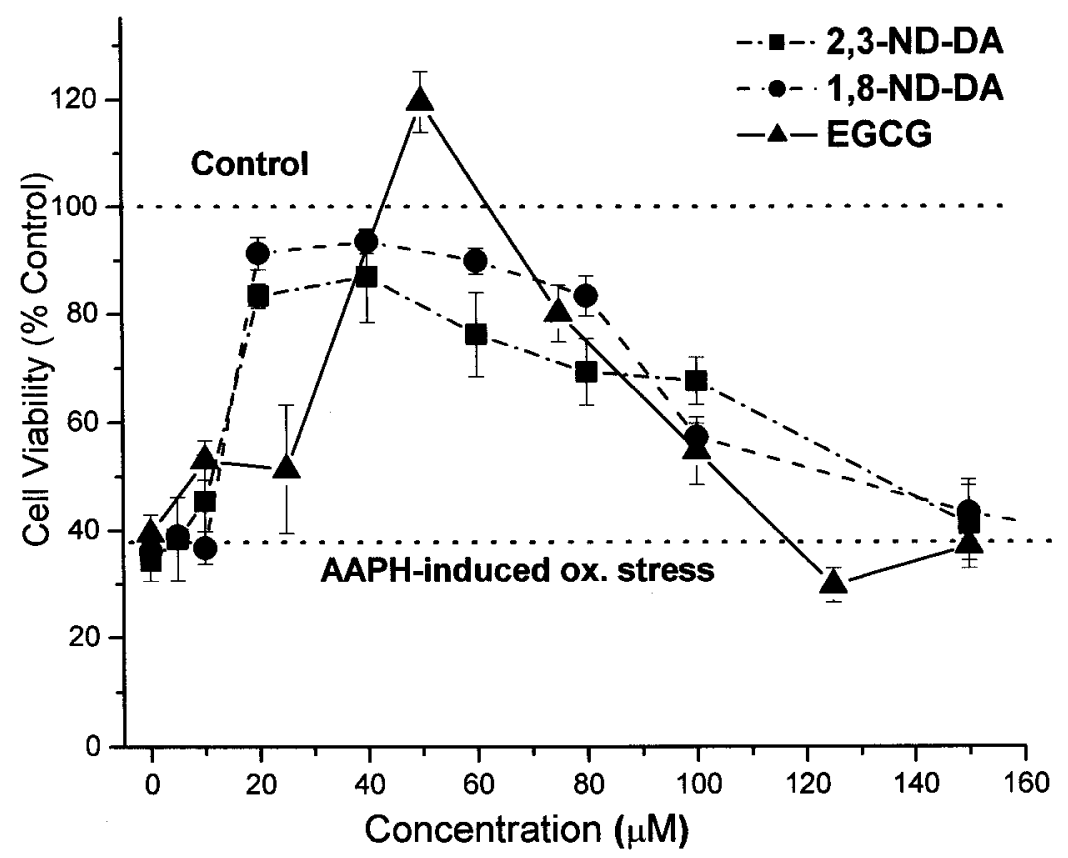

Figure 5.4. Cytoprotection of cortical neurons by selected naphthalenediols, in presence of AAPH (1.5 mM). Compounds tested: 2,3-ND, 1,8-ND (as diacetates) and EGCG. Protective zone: between dashed lines bounded by $38 \%$ viability (AAPHinduced stress) and Control. 
Figure 5.5 shows the Cytoprotective Area (CPA), as defined in chapter 4 and obtained from data for 1,8- ND. The CPA represents an integral over the viability/concentration plot, with contributions to the CPA occuring when the viability shows a protective effect due to compound. Here "Stress" represents the neuron viability in the presence of the stressor AAPH, applied for $24 \mathrm{~h}$ at a concentration of $1.5 \mathrm{mM}$ (i.e. no $1,8 \mathrm{ND}$ present). Figure 5.5 shows that the population of stressed cells has $38 \%$ viability relative to Control; this provides the lower boundary for the CPA integral. The upper boundary is provided by the cytotoxicity envelope (Figure. 5.2). The area of the bounded region (shaded, Figure 5.5) is the CPA, which provides an integrated comparison of the protection given between different compounds. The protective range is $5-170 \mu \mathrm{M}$, beyond which the inherent cytoxicity of 1,8-ND outweighs any protective effect (no protection can occur when the cell viability $<38 \%$ in this experiment, i.e. the tested compound has not reduced the oxidative stress). The total CPA for $1,8-\mathrm{ND}$ is ca. 5000 , in units of $\%$ Control $\mathrm{x} \mu \mathrm{M}$. The same procedure was repeated for the other compounds 2,3-ND and EGCG (Figures 5.6-5.7). These data are collected in the next section in Table 5.2. 


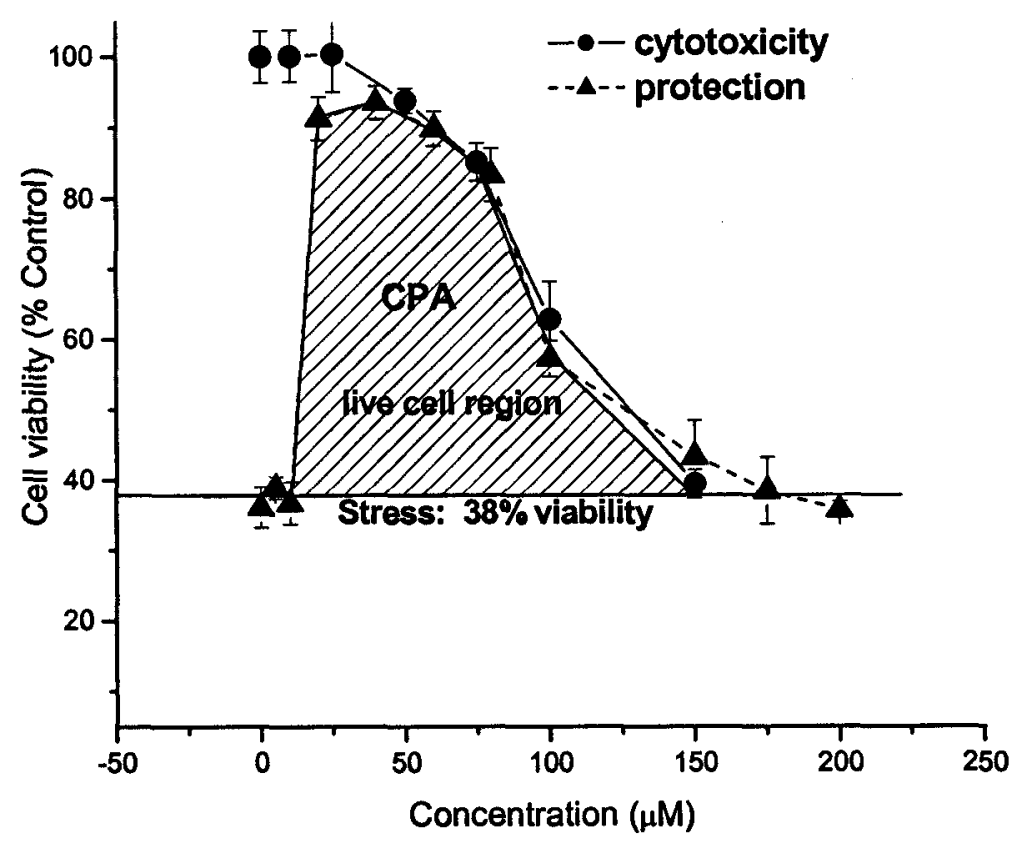

Figure 5.5. Total Cytoprotective Area for 1,8-ND (shaded regions). Boundaries: Cytoprotection experiment (from Figure 5.4) at left (triangles), cytotoxicity envelope (from Figure 5.2) at top (filled circles), viability in presence of AAPH stress (solid line, $38 \%$ relative to Control). 


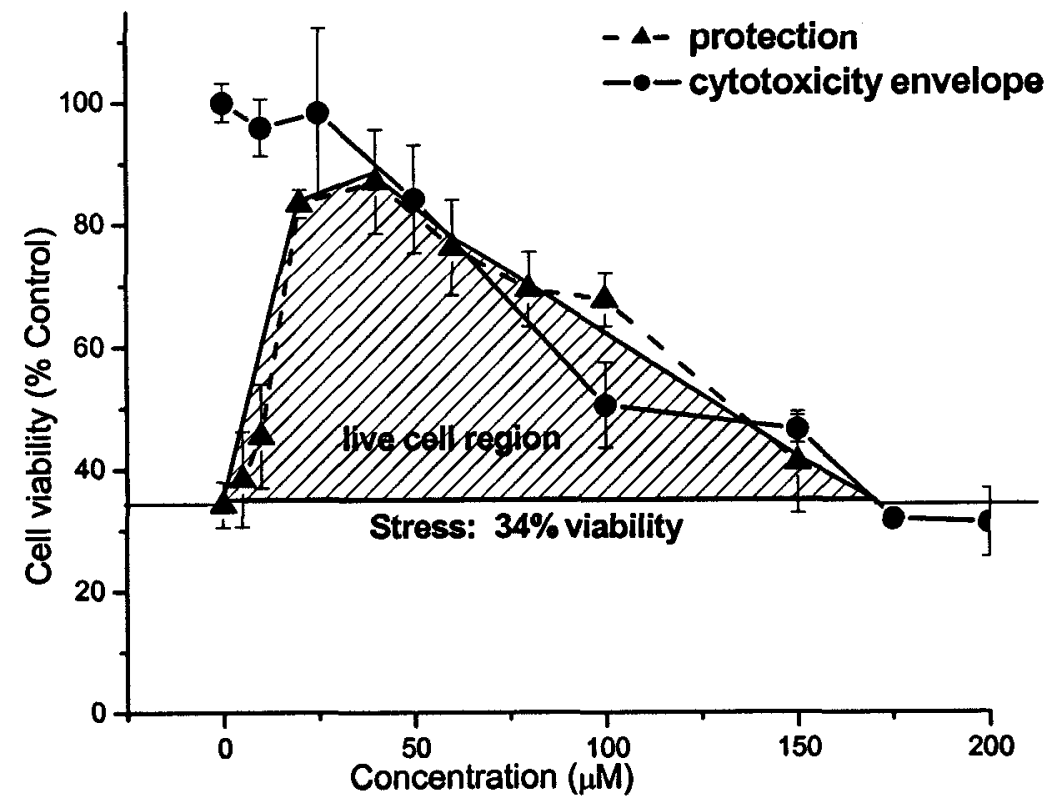

Figure 5.6. Total Cytoprotective Area for 2,3-ND (shaded regions).

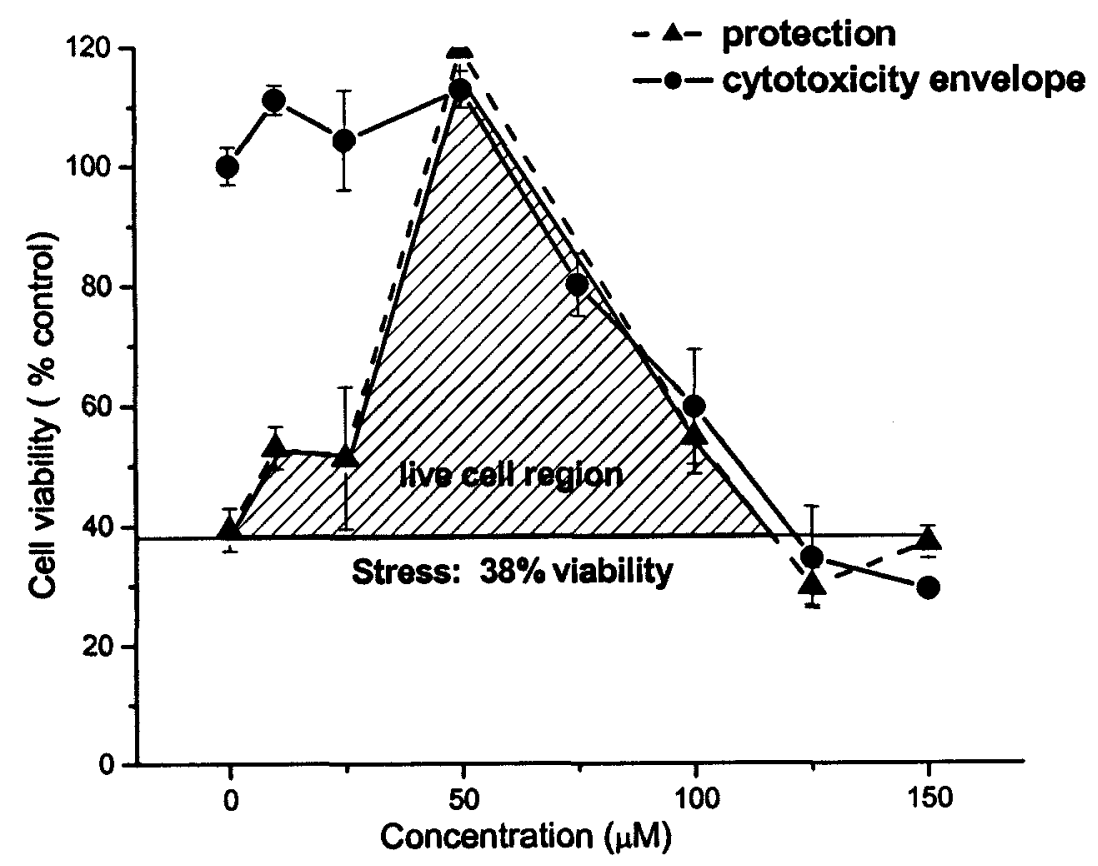

Figure 5.7. Total Cytoprotective Area for EGCG (shaded regions). 
When the AAPH testing was concluded, it was decided to extend this work to include another oxidative stressor. For this purpose glutamate, an excitory neurotransmitter was chosen, since it is commonly used to induce oxidative stress in neuronal cell culture work $[24,25]$. For these experiments the cells were subjected to 3 $\mathrm{h}$ exposure of glutamate over the concentration ranges $0.1-1 \mathrm{mM}$. Cell viability was established using the trypan blue assay after $24 \mathrm{~h}$ incubation of cells in NB27-AO (see Methods).

Figure 5.8 shows that for glutamate the $\mathrm{EC}_{50}$ is about $290 \pm 35 \mu \mathrm{M}$ under the conditions of our experiment. The $\mathrm{EC}_{50}$ values are sensitive to the parameters of the experiment. Relevant parameters are the percentage of supporting glia in the dishes and the initial neuron density, but I did not measure these parameters in the current work. (I used serum-free medium in order to diminish the number of glial cells, which heightens the response of the neurons to oxidative stress.)

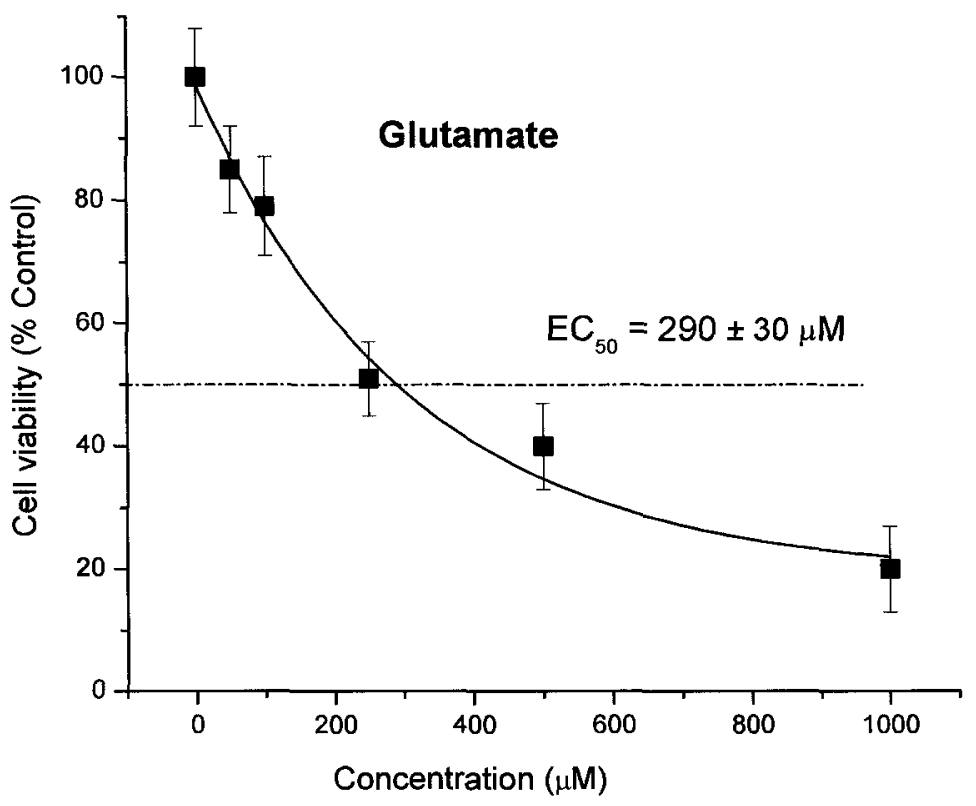

Figure 5.8. Cytotoxicity of glutamate to cortical neurons (trypan blue assay). 
Figures $5.9-5.11$ show images of cultured cortical neurons obtained by (PIXCELL II) inverted microscope after treating the cells with trypan blue. Figure 5.9 shows the cells (14 days old) after $24 \mathrm{~h}$ in medium NB27-AO and no treatment (no glutamate, no compound). This is defined as the Control. Two or three dead cells can be seen. The cell viability is very high. Figure 5.10 shows the cells image after $3 \mathrm{~h}$ exposure to $250 \mu \mathrm{M}$ glutamate and $24 \mathrm{~h}$ incubation of cells in NB27-AO. The cell viability was approximately $40 \%$ (trypan blue assay). Figure 5.11 shows the neurons preincubated with 1,8-ND-DA and then exposed to $250 \mu \mathrm{M}$ glutamate. The cells were rescued by treatment with the compound and only a few dead cells were counted in the dish.

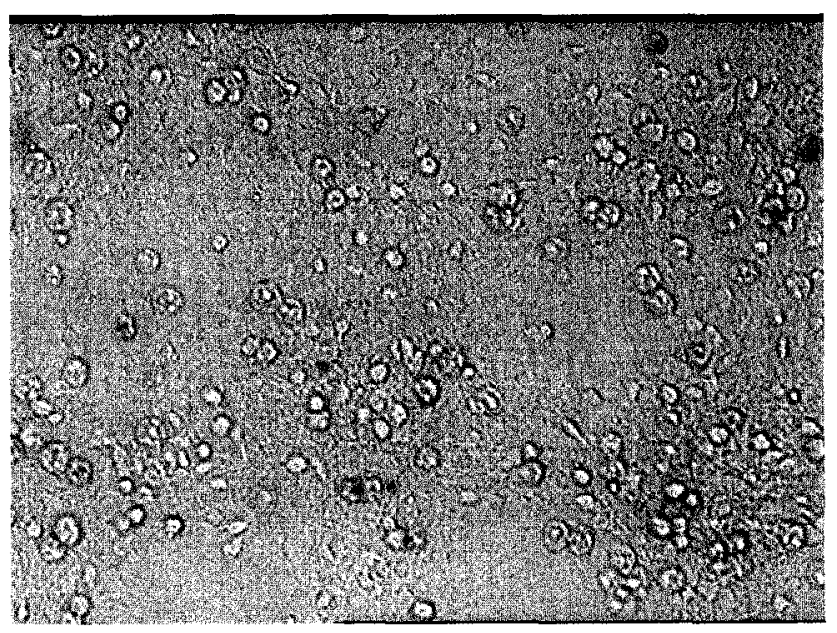

Figure 5.9. Image of primary cortical neurons with no treatment (Control). The cells were stained with trypan blue and counted using an inverted microscope. 


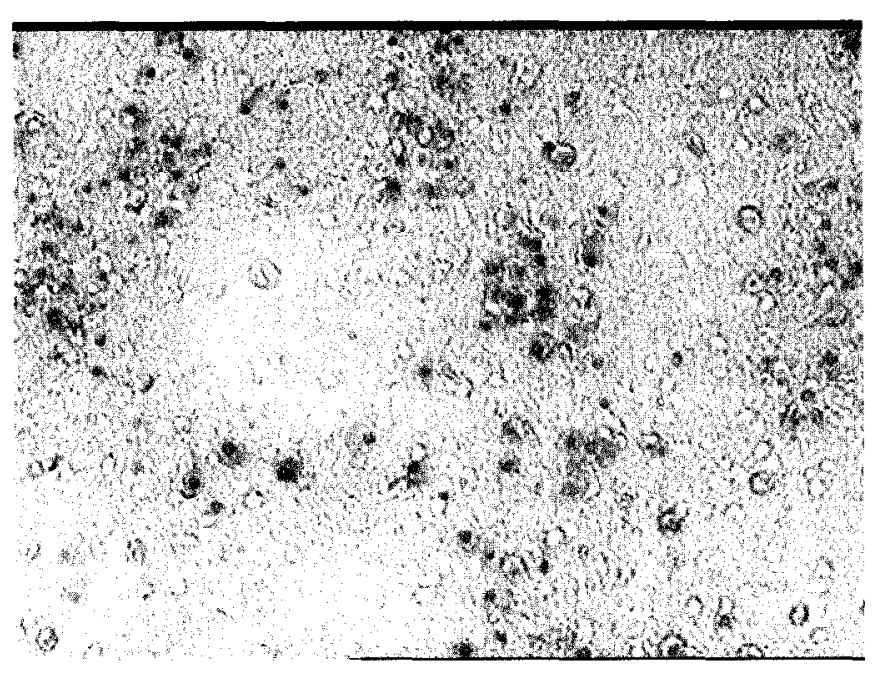

Figure 5.10. Image of primary cortical neurons stressed with $250 \mu \mathrm{M}$ glutamate. The cells were stained with trypan blue and the dead cells were counted under a PIXCELL II inverted microscope.

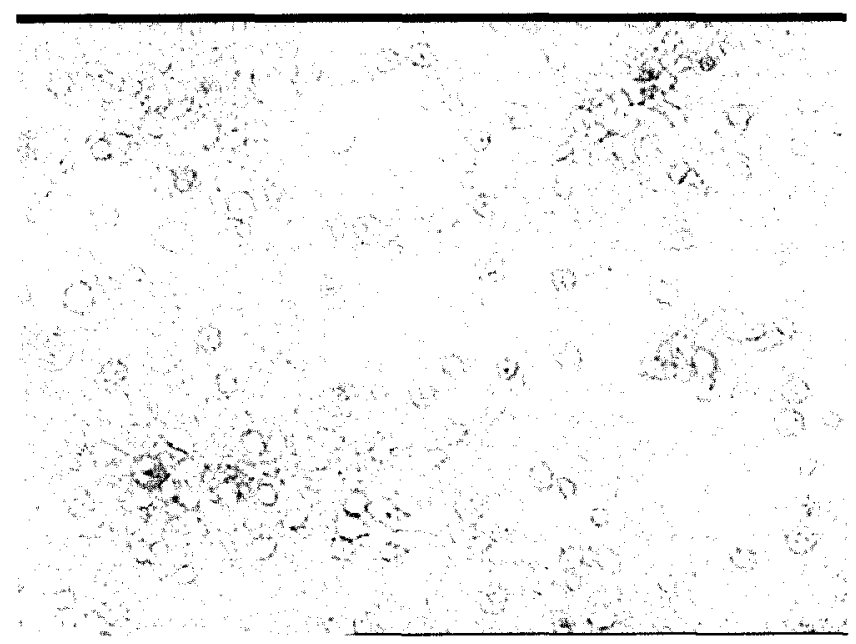

Figure 5.11. Image of primary cortical neurons stressed with $250 \mu \mathrm{M}$ glutamate and protected by $10 \mu \mathrm{M} 1,8-\mathrm{ND}-\mathrm{DA}$ treatment. The cells were stained with trypan blue and the dead cells were counted under a PIXCELL II inverted microscope. 
Figure 5.12 shows the cytoprotection resulting when 1,8-ND was added prior to glutamate treatment. A significant protective effect was observed at a concentration as low as $500 \mathrm{nM}$. For example, the cell viability was increased from $33 \pm 2 \%$ SEM (no 1,8-ND present) to $47 \pm 4 \% \mathrm{SEM}$ when $500 \mathrm{nM}$ compound was present. The cell viability goes up rapidly and monotonically with higher concentration, so that the viability at $10 \mu \mathrm{M}$ is already above $80 \%$. The effective concentration $\left(\mathrm{EC}_{50}\right)$ which is halfway between Control and Stress, i.e. 67\%, corresponds to $3.7 \mu \mathrm{M} 1,8-\mathrm{ND}$. Similarly, 2,3-ND at concentrations of $10-50 . \mu \mathrm{M}$ protects against glutamate...but concentrations below $10 \mu \mathrm{M}$ were not protective.

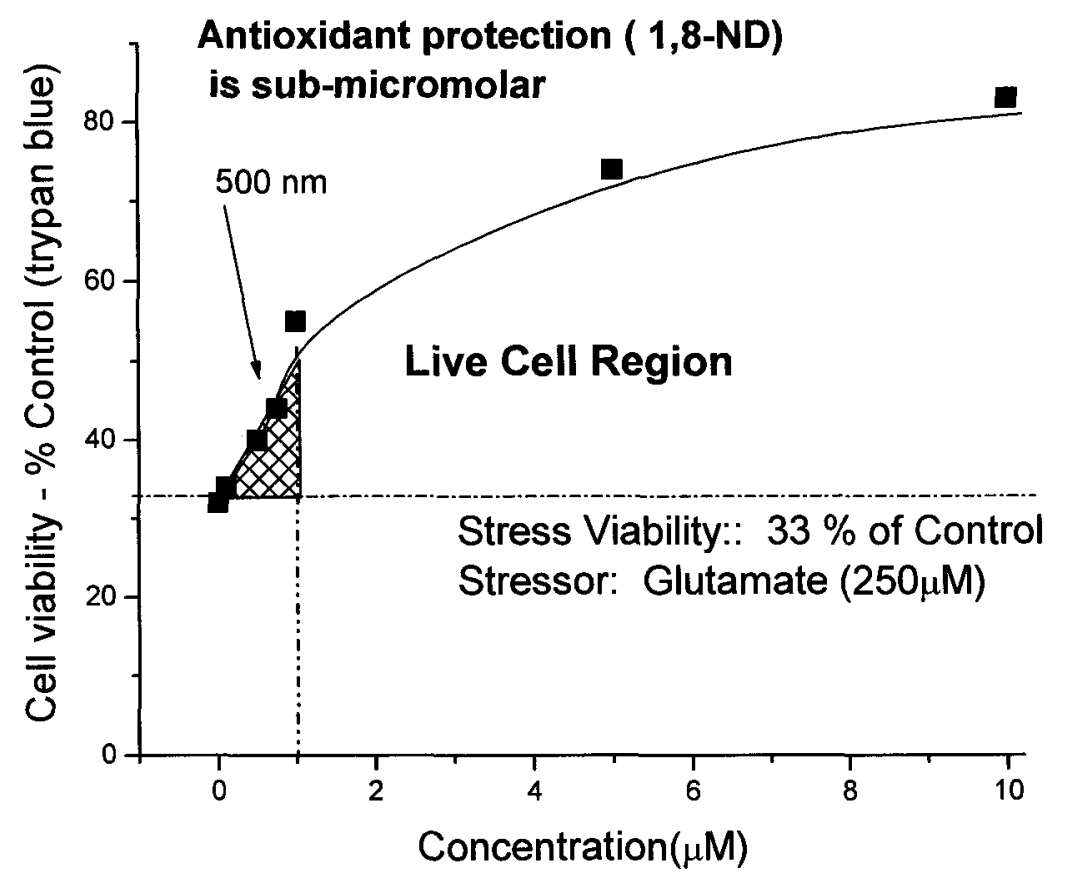

Figure 5.12. Cytoprotection of cortical neurons by $1,8-\mathrm{ND}$ showing low-dose protection; oxidative stressor is glutamate $(250 \mu \mathrm{M})$. 


\section{Theoretical.}

Theoretical calculations were included to aid in the discussion of the toxicity and protective effects of the compounds studied. Table 5.1 shows the calculated results for $\mathrm{BDE}_{1}$ and $\mathrm{BDE}_{2}$, the cytotoxicity expressed as the $\mathrm{EC}_{50}$ in PC12-AC [11] cells and cortical neurons, and the ratio between the $\mathrm{EC}_{50}$ 's for the two cell types.

Table 5.1. Calculated $\mathrm{BDE}_{1}$ and $\mathrm{BDE}_{2}$, the cytotoxicity $\mathrm{EC}_{50}$ for PC12-AC cells [11] and for cortical neurons and the ratio of the $\mathrm{EC}_{50}$ 's between the cell lines.

\begin{tabular}{|c|c|c|c|c|c|}
\hline Compound & BDE $_{\mathbf{1}}$ & BDE $_{\mathbf{2}}$ & EC $_{50}(\mu \mathrm{M})$ & EC $_{50}(\mu \mathrm{M})$ & Ratio \\
\hline 1,4-ND & 75 & 55 & $14 \pm 0.6$ & $4.75 \pm 1.2$ & 3.00 \\
\hline 1,2-ND & 70 & 69 & $40 \pm 3$ & $12.41 \pm 0.8$ & 3.33 \\
\hline 2,3-ND & 79 & 84 & $273 \pm 20$ & $118 \pm 20$ & 2.45 \\
\hline 1,8-ND & 72 & $104^{\mathbf{a}}$ & $250 \pm 20$ & $128 \pm 7$ & 2.12 \\
\hline EGCG & 71 & 74 & $456 \pm 16$ & $110 \pm 10$ & 4.30 \\
\hline
\end{tabular}

${ }^{\mathrm{a}}$ Triplet diradical state

Table 5.2 summarizes the concentration range which is cytoprotective for rat cortical neurons, the concentration which provides the maximum protective effect, the CPA in $\mathrm{PC} 12-\mathrm{AC}$ cells and the CPA in neurons. 
Table 5.2. Cytoprotective efficacy of antioxidants against oxidative stress induced by $1.5 \mathrm{mM}$ AAPH. Incubation time is $24 \mathrm{~h}, 2 \mathrm{~h}$ pretreatment with antioxidant.

\begin{tabular}{|c|c|c|c|c|}
\hline Compound & $\begin{array}{c}\text { Range }^{a}(\mu \mathrm{M}) \\
\text { Neurons }\end{array}$ & $\begin{array}{c}\text { Max (\% Control) } \\
\text { Neurons }\end{array}$ & $\begin{array}{c}\text { CPA PC12-AC } \\
(\% \text { Control } \cdot \boldsymbol{\mu M})^{b}\end{array}$ & $\begin{array}{c}\text { CPA neurons } \\
(\% \text { Control } \cdot \boldsymbol{\mu M})\end{array}$ \\
\hline 1,2-ND & $2-5$ & 53 & 100 & ca. 75 \\
\hline 1,4-ND & $3-10$ & $70 @ 5 \mu \mathrm{M}$ & $285 \pm 20$ & $50 \pm 3$ \\
\hline 2,3-ND & $5-150$ & $90 @ 40 \mu \mathrm{M}$ & $7225 \pm 293$ & $4810 \pm 170$ \\
\hline 1,8-ND & $5-150$ & $93 @ 40 \mu \mathrm{M}$ & $9030 \pm 200$ & $5080 \pm 145$ \\
\hline EGCG & $10-120$ & $110 @ 50 \mu \mathrm{M}$ & $17,300 \pm 1240$ & $3990 \pm 340$ \\
\hline
\end{tabular}

${ }^{a}$ Total protective range; only the region above "Stress" is counted (see Figure 5.5),

${ }^{\mathrm{b}}$ Unit for Cytoprotective Area 


\subsection{DISCUSSION}

\section{Toxicity}

Figure 5.2 shows that for the naphthalenediols tested here, two are relatively toxic $(1,2-$ and $1,4-\mathrm{ND})$ whereas two are relatively nontoxic $(2,3-$ and $1,8-\mathrm{ND})$ to rat cortical neurons. The cytotoxicity of the latter pair is comparable to that of EGCG which is generally thought to be neuroprotective [16-18]. In fact, these results are very similar to those found in the adrenal cell line PC12-AC. Thus, Table 1 shows that for the four naphthalenediols the order of cytotoxicity is essentially identical between the two cell lines, as measured by the $\mathrm{EC}_{50}$ for each. Under the conditions of the two experiments the rat cortical neurons are seen to be more sensitive to the compounds by a factor of approximately 3. It is clear that EGCG differs somewhat from this pattern since it by far the least toxic of the group in PC12-AC although it is comparable in toxicity to 2,3-ND and 1,8-ND in cortical neurons.

\section{Cytoprotection against $\boldsymbol{A} \boldsymbol{A P H}$}

As with cytotoxicity, there are clear trends in the cytoprotective effectiveness which transcend cell lines. Table 5.2 compares the cytoprotective areas (CPA's) obtained using AAPH as oxidative stressor. Comparing just the naphthalenediols, both 1,2-ND and 1,4-ND have only a small CPA rendering them useless as antioxidants. 2,3-ND and 1,8-ND, on the other hand, have about 2 orders of magnitude greater CPA. EGCG is most effective in PC12-AC cells by a factor of two, 
however in the neurons both 2,3- and 1,8-ND have higher CPA's than EGCG. Qualitatively, then, the cytoprotective behavior is similar for the two cell lines.

\section{Peroxyl radical mechanism, effect of $B D E$}

For naphthalenediols possessing two exchangeable $\mathrm{H}$-atoms, $\mathrm{BDE}_{1}$ describes the tendency for semiquinone formation. Here the compound is acting as an antioxidant, according to $\mathrm{NQH}_{2}+\mathrm{ROO}^{\bullet} \rightarrow \mathrm{NQH}^{\bullet}+\mathrm{ROOH}$, breaking the chain reaction of lipid peroxidation, so lower values of $\mathrm{BDE}_{1}$ mean a faster reaction rate with peroxyl radicals and hence better radical scavenging. $\mathrm{BDE}_{2}$ describes the tendency to go from semiquinone to quinone, i.e. $\mathrm{NQH}^{\bullet}+\mathrm{ROO}^{\bullet} \rightarrow \mathrm{NQ}+\mathrm{ROOH}$. Note that due to the typically low $\mathrm{pK}_{\mathrm{a}}$ of semiquinones (ca. 4.0), $\mathrm{NQH}^{\bullet}$ actually exists in the deprotonated form $\mathrm{NQ}^{\bullet-}$ at physiological $\mathrm{pH}$, which reacts preferentially by electron transfer rather than H-atom transfer (HAT). However, the energetics are related and HAT is still useful as a predictor of reactivity. Once $\mathrm{NQ}^{\bullet-}$ formation occurs, redox cycling between semiquinone radical anion and quinone leads to formation of superoxide and related species [15], or thiol depletion by nucleophilic addition to the electrophilic quinone. Both mechanisms cause cytotoxicity via these prooxidant behaviours (generation of superoxide, or removal or protective thiols) and hence low values of $\mathrm{BDE}_{2}$ are to be avoided. Table 2 shows that based on $\mathrm{BDE}_{2}$ values the predicted order of cytotoxicity is $1,4>1,2>2,3>1,8-\mathrm{ND}$. This is

essentially the order observed, although the $\mathrm{BDE}_{2}$ for formation of 2,3- 
naphthoquinone is already sufficiently high $(84 \mathrm{kcal} / \mathrm{mol})$ that no such quinone is formed; this makes 2,3-ND and 1,8-ND comparably non-toxic.

\section{EGCG quinone is non-toxic}

EGCG has a relatively low $\mathrm{BDE}_{2}(74 \mathrm{kcal} / \mathrm{mol}$, Table 2$)$ and hence is expected to be relatively toxic, contrary to observation. However, the pyrogallol moiety (i.e. 1,2,3-trihydroxybenzene) forms a special type of quinone since it has a third active hydrogen (or electron). Scheme 5.1 shows the conversion of pyrogallol into 3hydroxy-1,2-benzoquinone. The hydroxyquinone is very acidic $\left(\mathrm{pK}_{\mathrm{a}}=4.3\right)$ and hence the molecule is an anion at $\mathrm{pH}$ 7.4. The strongly electron-donating $\mathrm{O}^{-}$group changes the electronic character of the quinone so that it is no longer electrophilic, and hence not subject to nucleophilic attack. This removes the first source of toxicity. The anion in Scheme 5.2 is unlikely to donate an electron to oxygen, since this would leave two electron-withdrawing carbonyl groups and an electron-withdrawing oxygen radical on the aromatic ring; three dipoles oriented in the same direction are repulsive and hence not favored energetically. It is also unlikely to redox cycle since it will not be subject to reduction by cytochrome $\mathrm{P} 450$ reductase, due to the presence of the negative charge. This removes the three main sources of toxicity hence the observation that EGCG, which contains the pyrogallol moiety, is relatively non-toxic. 


\section{SCHEME 5.1}<smiles>C=CC1C=CC=C(O)C1=O</smiles>

\section{SCHEME 5.2}<smiles>O=C1C=CC=C([O-])C1=O</smiles>

\section{Comparison of toxicity and protection in immortal vs. primary neuronal cells}

I expect that the generalizations on cytotoxicity established for the naphthalenediols should hold up for other cell lines as well, although the precise ratios of the $\mathrm{EC}_{50}$ 's will depend on the conditions of the experiment, especially the plating density of the cells. Thus I can predict that the order of cytotoxicity in any cell line will be 1,4-ND > 1,2-ND > 2,3-ND > 1,8-ND, with EGCG being generally of toxicity comparable to or less than the least toxic naphthalenediol, 1,8-ND. Similarly, 2,3-ND and 1,8-ND should show significant cytoprotective effects whereas 1,2-ND and 1,4-ND should not. For such generalizations to hold, there must be a consistent mechanism underlying the observed toxicity. As discussed in the introduction, the data are unified by the tendency of the naphthalenediols to form naphthoquinones. This tendency explains the data and allows prediction of toxicity for other naphthalenediols as well. 


\section{Cytoprotection against glutamate}

Additional experiments on 1,8-ND using glutamate as oxidative stressor showed significant protective effects at low (sub- $\mu \mathrm{M})$ concentrations. In order to explain the very high protection given by $\mathrm{nM}$ concentrations of $1,8-\mathrm{ND}$, two mechanisms are possible: First, the ability of the compound to scavenge ROS which, if not deactivated, leads to neuronal cell death, and second, the prevention of apoptosis in cortical neurons exposed to glutamate by blocking $N$-methyl-D-aspartic acid (NMDA) receptors. The mechanism of glutamate neurotoxicity can be divided into acute and delayed toxicity. Delayed neurotoxicity of glutamate is calcium-dependent. Glutamate binds to the NMDA receptor and an influx of extracellular $\mathrm{Ca}^{2+}$ leads to a cascade of events leading to oxidative stress. Superoxide generation is then initiated. [25-28].

Using the patch-clamp method we found that the addition of 1,8-ND had no effect on the ongoing NMDA receptor-driven spontaneous activity present in these cultures (data not shown) [29-31]. Therefore, we eliminate blocking of the NMDA receptor as the mechanism of cytoprotection caused by 1,8-ND. That means either the low-dose protection (Fig. 5.7) given by 1,8-ND under conditions of glutamate stress is caused by simple antioxidant activity, or more subtle effects are involved, e.g. cellular signaling $[19,20,32,33]$.

\subsection{CONCLUSION}

Certain members of the naphthalenediol family show good activity in scavenging peroxyl radicals, while being of toxicity comparable to that in naturally 
occurring polyphenols. These compounds showed similar behavior in PC-12 cells and thus the explanation for their cytotoxicity and cytoprotective activity crosses multiple cell lines. This can be understood from the mechanistic discussion, i.e. the tendency to form naphthoquinones is related to the loss of aromaticity (or not) in the quinone moiety. In fact, some of the same arguments have been used to explain cytotoxicity in steroid chemistry, where quinones are also involved [34,35]. In terms of drug development, it will be of interest to see how well the naphthalenediols penetrate the blood-brain barrier in animal models, and to look at the toxicity of metabolites.

\subsection{REFERENCES}

1. Cohen, G. (1994) Free radical, oxidative stress and neurodegeneration. Neurodeg. Diseases 10, 139-161.

2. Bowling, A. C., and Beal, M. F. (1995) Bioenergetic and oxidative stress in neurodegenerative diseases. Life Sci. 56, 1151-1171.

3. Esposito, E., Rotilio, D., Di Matteo, V., Di Giulio, C., Cacchio, M., and Algeri, S. (2002) A review of specific dietary antioxidants and the effects on biochemical mechanisms related to neurodegenerative processes. Neurobiol. Aging 23, 719-735.

4. Joseph, J. A., Shukitt-Hale, B., Denisova, N. A., Prior, R. L., Cao, G., Martin, A., Taglialatela, G., and Bickford, P. C. (1998) Long-term dietary strawberry, spinach or vitamin E supplementation retards the onset of age-related neuronal signaltransduction and cognitive behavioral deficits. J. Neurosci. 18, 8047-8055. 
5. Joseph, J. A., Shukitt-Hale, B., Denisova, N. A., Bielinski, D., Martin, A., McEwen, J. J., and Bickford, P. C. (1999) Reversals of age-related declines in neuronal signal transduction, cognitive, and motor behavioral deficits with blueberry, spinach, or strawberry dietary supplementation. J. Neurosci. 19, 8114-8121.

6. Burton, G. W., and Ingold, K. U. (1986) Vitamin E: application of the principles of physical organic chemistry to the exploration of its structure and function. Acc. Chem. Res. 19, 194-201.

7. Noguchi, N., and Niki, E. (2000) Phenolic antioxidants: A rationale for design and evaluation of novel antioxidant drug for atherosclerosis. Free Radical Biol. Med. 28, 1538-1546.

8. Wright, J. S., Johnson, E. R., and DiLabio, G. A. (2001) Predicting the activity of phenolic antioxidants: Theoretical method, analysis of substituent effects, and application to major families of antioxidants. J. Am. Chem. Soc. 123, 1173-1183.

9. Mulder, P., Korth, H.- G., and Ingold, K. U. (2005) Why quantum-thermochemical calculations must be used with caution to indicate 'a promising lead antioxidant'. Helv. Chim. Acta 88, 370-374.

10. Zhang, H.-Y. (2005) Structure - Activity Relationships and rational design strategies for radical-scavenging antioxidants. Curr. Comput.-Aided Drug Des. 1, 257-273.

11. Flueraru, M., Chichirau, A., Chepelev, L. L., Willmore, W. G., Durst, T., Charron, M., Barclay, L. R. C., and Wright, J. S. (2005) Cytotoxicity and cytoprotective activity 
in naphthalenediols depends on their tendency to form naphthoquinones. Free Radical Biol. Med. 39, 1368-1377.

12. Chichirau, A., Flueraru, M., Chepelev, L. L., Wright, J. S., Willmore, W. G., Durst, T., Hussain, H. H., Charron, M. (2005) Mechanism of cytotoxicity of catechols and a naphthalenediol in PC12-AC cells: the connection between extracellular autoxidation and molecular electronic structure. Free Radical Biol. Med. 38, 344-355.

13. Gant, T. W., Rao, D. N., Mason, R. P., and Cohen, G. M. (1988) Redox cycling and sulphydryl arylation: their relative importance in the mechanism of quinone cytotoxicity to isolated hepatocytes. Chem Biol. Inter. 65, 157-173.

14. Brunmark, A., and Cadenas, E. (1989) Redox and addition chemistry of quinoid compounds and its biological implications. Free Radical Biol. Med. 7, 435-477.

15. O'Brien, P. J. (1991) Molecular mechanisms of quinone cytotoxicity. Chem. Biol. Inter. $80,1-41$

16. Lee, S.- R., Suh, S.- I., and Kim, S.-P. (2000) Protective effects of the green tea polyphenol (-)-epigallocatechin gallate against hippocampal neuronal damage after transient global ischemia in gerbils. Neurosci. Lett. 287, 191-194.

17. Mandel, S., Levites, Y., Weinreb, O., and Youdim, M. B. H. (2002) Neuroprotective actions of green tea polyphenol, (-)-epigallocatechin-3-gallate in models of Parkinson's disease: gene targets. Adv. Behavioral Biol. 53 (Catecholamine Res.), 463-466. 
18. Lee, H., Bae, J. H., and Lee, S.- R. (2004) Protective effect of green tea polyphenol EGCG against neuronal damage and brain edema after unilateral cerebral ischemia in gerbils. J. Neurosci. Res. 77, 892-900.

19. Weinreb, O., Mandel, S., Amit, T., and Youdim, M. B. H. (2004) Neurological mechanism of green tea polyphenols in Alzheimer's and Parkinson's diseases. J. Nutr. Biochem. 15, 506-516.

20. Mandel, S., Weinreb, O., Amit, T., and Youdim, M.B.H. (2004) Cell signaling pathways in the neuroprotective actions of the green tea polyphenol (-)epigallocatechin-3-gallate: implications for neurodegenerative diseases. $J$. Neurochem. $88,1555-1569$.

21. Rogers, A., Schmuck, G., Scholz, G., and Williams, D.C. (2004) c-fos mRNA expression in rat cortical neurons during glutamate-mediated excitotoxicity. Toxicol. Sci. $82,562-569$.

22. Yu, X., Sun, L., Luo, X., Xu, Z., and An, L. (2003) Investigation of the neuronal death mode induced by glutamate treatment in serum-, antioxidant-free primary cultured cortical neurons. Dev. Brain Res. 145, 263-268.

23. DiLabio, G. A., Pratt, D. A., LoFaro, A. D., and Wright, J. S. (1999) Theoretical study of $\mathrm{X}-\mathrm{H}$ bond energetics $(\mathrm{X}=\mathrm{C}, \mathrm{N}, \mathrm{O}, \mathrm{S})$ : application to substituent effects, gas phase acidities and redox potentials. J. Phys.Chem. A 103, 1653-1661.

24. Coyle, J. T., and Puttfarcken, P. (1993) Oxidative stress, glutamate, and neurodegenerative disorders. Science 262, 689-695. 
25. Castilho, R. F., Ward, M. W., and Nicholls, D. G. (1999) Oxidative stress, mitochondrial function, and acute glutamate excitotoxicity in cultured cerebellar granule cells. J. Neurochem. $72,1394-1401$.

26. Lafon-Cazal, M., Pietri, S., Culcasi, M., and Bockaert, J. (1993) NMDAdependent superoxide production and neurotoxicity. Nature 364, 535-537.

27. Reynolds, I. J., and Hastings, T. G. (1995) Glutamate induces the production of reactive oxygen species in cultured forebrain neurons following NMDA receptor activation. J. Neurosci. 15, 3318-3327.

28. Atlante, A., Callisano, P., Bobba, A., Giannattasio, S., Marra, E., and Passarela, S. (2001) Glutamate neurotoxicity, oxidative stress and mitochondria. FEBS Lett. 497, $1-5$.

29. Kume, T., Katsuki, H., and Akaike, A. (2004) Endogenous factors regulating neuronal death induced by radical stress. Biol. Pharm. Bull. 27, 964-967.

30. Arundine, M., and Tymianski, M. (2004) Molecular mechanisms of glutamatedependent neurodegeneration in ischemia and traumatic brain injury. Cell Mol. Life Sci. $61,657-668$.

31. Jacintho, J. D., and Kovacic, P. (2003) Neurotransmission and neurotoxicity by nitric oxide, catecholamines, and glutamate: unifying themes of reactive oxygen species and electron transfer. Curr. Med. Chem. 10, 2693-2703.

32. Williams, R. J., Spencer, J. P. E., and Rice-Evans, C. (2004) Flavonoids: Antioxidants or signaling molecules? Free Radical Biol. Med. 36, 838-849. 
33. Gamet-Payrastre, L., Manenti, S., Gratacap, M. - P., Tulliez, J., Chap, H., and Payrastre, B. (1999) Flavonoids and the inhibition of PKC and PI 3-kinase. Gen. Pharmacol. 32, 279-286.

34. Yager, J. D., and Liehr, J. G. (1996) Molecular mechanisms of estrogen carcinogenesis. Annu. Rev. Pharmacol. Toxicol. 36, 203-232.

35. Bolton, J. L., Pisha, E., Zhang, F., and Qui, Shengxiang. (1998) Role of quinoids in estrogen carcinogenesis. Chem. Res. Toxicol. 11, 1113-1127. 


\section{Chapter 6}

\section{General Conclusions}


The Bond Dissociation Enthalpy (BDE) in phenolic antioxidants is an essential tool in determining the efficacy of a chain-breaking antioxidant. The weaker the $\mathrm{O}-\mathrm{H}$ bond, the faster will be the reaction with free radicals (peroxyl radicals). A "design window" was defined between $68-75 \mathrm{kcal} \mathrm{mol}^{-1}$, into which the BDE of active bond $\mathrm{O}-\mathrm{H}$ of the new antioxidants should fit [1].

Novel antioxidants with BDEs values of the $\mathrm{O}-\mathrm{H}$ bond between $69-75 \mathrm{kcal} / \mathrm{mol}$ were designed, synthesized and tested for reactivity with the stable 2,2-diphenyl-1picrylhydrazyl free radicals (DPPH) in organic solvent and in HL-60 cell culture. A good correlation was found between rates of reaction with DPPH radicals and BDEs and also between $\mathrm{IC}_{50}$ 's (concentration of antioxidant that provides $50 \%$ inhibition) and BDEs. Both assays can be considered as good models to evaluate the antioxidant capacity of a compound.

Three synthetic catechols H1 (a p-methoxycatechol), H2 (a catechol analog of $\alpha$ tocopherol), and H4 (a dioxymethylene-substituted catechol), their diacetates H1-DA, H2-DA, H4-DA (DA = diacetate) and a well know antioxidant, epigallocatechin gallate (EGCG) were tested for cytotoxicity and protection against oxidative stress in rat pheochromocytoma (PC12-AC) cells, both with and without $50 \mu \mathrm{M}$ ascorbate. Oxidative stress was induced by menadione and the peroxyl radical generator AAPH. Using assays for $\mathrm{H}_{2} \mathrm{O}_{2}$ and reduced glutathione $(\mathrm{GSH})$, as well as calculated values of solubility $(\log \mathrm{P})$ and bond dissociation enthalpy (BDE), I discussed the cytotoxicity with reference to properties of the parent catechol, the semiquinone and the quinone. We found that the two pure redox-cycling catechols, $\mathrm{H} 1$ and $\mathrm{H} 2$ and their diacetates, have a strong nearlinear dose-dependence in their $\mathrm{H}_{2} \mathrm{O}_{2}$ response, which correlated well with their 
cytotoxicity and with the effect of added ascorbate. For the combined redox cyclingGSH depleting compound $\mathrm{H} 4$, less peroxide was formed. In all three compounds, GSH increased relative to control (upregulation of total GSH production). Use of a BDE argument helped us to correlate toxicity both with and without the presence of added ascorbate. In cytoprotection assays, H2-DA showed a narrow zone of protective behavior (5 to $40 \mu \mathrm{M}$ ) compared with EGCG which demonstrated an extended range of protection ( 5 to $575 \mu \mathrm{M}$ ) when cells where stressed with AAPH. In general, the catechols react quickly with radicals but show toxic effects due to redox cycling. This required a redesign of the compounds in order to minimize quinone formation. This led to an investigation of naphthalenediols.

The cytotoxicity and protection against oxidative stress for five members of the naphthalenediol family, as well as the known antioxidant EGCG, was tested. The compounds tested included 1,2-naphthalenediol (1,2-ND), 1,4-ND, 2,3-ND, 1,8-ND and 1,4-dipropyl-2,3-naphthalenediol (DPND). Compounds were tested for their cytotoxicity as well as their antioxidant capacity on an adherent clone of rat pheochromocytoma (PC12AC). Oxidative stress was induced by the peroxyl radical generator AAPH. The relative order of cytotoxicity (most toxic to least toxic) was found to be 1,4-ND > 1,2-ND $>$ DPND $>2,3-\mathrm{ND}>1,8-\mathrm{ND}>>\mathrm{EGCG}$, with $\mathrm{EC}_{50}$ 's of $15,40,160,>250,>250,>>250$ $\mu \mathrm{M}$, respectively. In spite of their high toxicity, both 1,4-ND and 1,2-ND showed narrow zones of protective behavior whereas DPND, 2,3-ND and 1,8-ND and especially EGCG showed extended ranges of protection. The total protection obtained for the combination of cells/oxidative stressor/protective compounds (PC12-AC/AAPH/naphthalenediols) can be defined, in general, by an integrated measure termed the Cytoprotective Area (CPA). 
I related the observed cytotoxicity and CPA to the different electronic structures of the naphthalenediols, characterized theoretically by the first and second bond dissociation enthalpies (BDEs) as well as the $\mathrm{pK}_{\mathrm{a}}$ 's for the parent (diol) and semiquinone compounds. Since the 2,3- and 1,8-NDs do not form quinones, their cytotoxicity is much lower than for the compounds which do. Thus, selected members of the naphthalenediol family show promise as antioxidants. I also examined the effect of added ascorbate on cytotoxicity of naphthalenediols. I found that 2,3-ND and DPND become less toxic by adding ascorbate, 1,4-ND and 1,8-ND are unaffected by ascorbate and the toxicity of 1,2ND is increased when the ascorbate is present. The calculated BDEs correlated to their observed toxicity. I also designed and tested derivatives of 1,8-ND for cytotoxicity and cytoprotection. The order of cytoprotection is $1,8-\mathrm{ND}-\mathrm{DA}>1,8-\mathrm{ND}-\mathrm{DA}$ acrylamide $>$ 1,8-ND glycerate $>1,8-\mathrm{ND}-\mathrm{DA}$ ester. Thus certain members of the naphthalenediol family and their derivatives show promise as antioxidants. To test if these conclusions were universal, naphthalenediols were also tested on primary neurons.

The effect of naphthalenediols on rat primary cortical neurons exposed to AAPH. was investigated. Compounds tested included the acetylated forms of 1,2naphthalenediol, i.e.1,2-ND, as well as 1,4-ND, 2,3-ND, 1,8-ND, and the known highly potent antioxidant EGCG. This set of compounds was the same as those used in the PC12-AC studies. In neuron cytotoxicity studies, cells were exposed to the compounds for $24 \mathrm{~h}$, leading to observed toxicity in the order of $1,4-\mathrm{ND}>1,2 \mathrm{ND}>>2,3-\mathrm{ND} \approx$ EGCG $>1,8-N D$. In cytoprotection studies, the desired compounds were incubated with neurons prior to AAPH exposure, and live cell counts were determined by trypan blue and/or MTT assays. Excellent protection, superior to EGCG, was provided by 2,3-ND 
and 1,8-ND. Additional studies using glutamate as a stressor showed that 1,8-ND had a significant protective effect at concentrations as low as $500 \mathrm{nM}$. The results can be understood based on the tendency (or lack thereof) to form the corresponding quinone, which in turn depends on whether or not there is a loss of aromaticity in the ring adjacent to the quinone moiety. Thus, certain members of the family of naphthalenediols are quite cytotoxic whereas others show promise as neuroprotective antioxidants. Therefore these conclusions have been demonstrated in two cell lines, the immortalized cells (PC12-AC) and the primary cells (cortical neurons). I expect that these conclusions will hold for other cell lines, because the underlying chemical mechanism related to quinone formation is universal.

In conclusion, the thesis has demonstrated the following:

1) Weakening the $\mathrm{OH}$ bond leads to a faster reaction with free radicals in organic solvents (DPPH radicals) and in HL-60 cells (superoxide radicals and the related hydroperoxyl radicals). This was demonstrated in Chapter 2 for a series of catechols which had $\mathrm{BDE}_{1}$ in the design window $68-75 \mathrm{kcal} \mathrm{mol}^{-1}$.

2) The designed catechols were tested for cytotoxicity and cytoprotective effects in Chapter 3, using PC12-AC cells. The catechols were found to be quite cytotoxic due to the formation of quinones. This required a redesign of antioxidants to avoid quinone formation, e.g. by creating molecules with a high $\mathrm{BDE}_{2}$.

3) A series of naphthalenediols were prepared and tested for their cytotoxicity and cytoprotection effects, as described in Chapter 4. The 1,2- and 1,4-NDs were very cytotoxic, due to the formation of the quinone. On the other hand, the 2,3- and 1,8-NDs were relatively non-toxic and, at the same time, cytoprotective due to their high $\mathrm{BDE}_{2}$ 
which prevented quinone formation. Measures of efficacy showed that these compounds are comparable to or even superior to the well-known antioxidant EGCG.

4) To test whether the mechanism was universal, experiments were carried out on a primary cell line in Chapter 5. Rat cortical neurons, exposed to the stressors AAPH and glutamate, showed that the 1,8-NDs are highly cytoprotective.

5) Thus the 1,8- and 2,3-ND family of compounds provided a promising starting point for a new type of antioxidant. This could be extended to investigations using higher organisms to test for therapeutic effects when the organism is subjected to oxidative stress.

\section{REFERENCE:}

1. Hussain, H. H., Babic, G., Durst, T., Wright, J. S., Flueraru, M., Chichirau, A., and Chepelev, L. L. (2003) Development of novel antioxidants: Design, synthesis and reactivity. J. Org. Chem. 68, 7023-7032. 


\section{PUBLICATION LIST}

\section{a). Articles published or accepted in refereed journal}

1. Flueraru, M., Willmore, W. G., Poulter, M. O., Durst, T., Charron, M., and Wright, J. S. (2006) Cytotoxicity and cytoprotective activity of naphthalenediols in rat cortical neurons: Chem. Res. Toxicol. (in press).

2. Flueraru, M., Chichirau, A., Chepelev, L.L., Willmore, W. G., Durst, T., Charron, M., Barclay, L.R.C., and Wright, J. S. (2005) Cytotoxicity and cytoprotective activity in naphthalenediols depends on their tendency to form naphthoquinones. Free Rad. Biol. Med. 39, 1368-1377.

3. Chichirau, A., Flueraru, M., Chepelev, L.L., Wright, J. S., Willmore, W. G., Durst, T., Hussain, H. H., and Charron, M. (2005) Mechanism of cytotoxicity of catechols and a naphthalenediol to PC12-AC cells: The connection between extracellular autoxidation and molecular electronic structure. Free Rad. Biol. Med. 38, 344-355.

4. Hussain, H., Babic, G., Durst, T., Wright, J. S., Flueraru, M., Chichirau, A., and Chepelev, L.L. (2003) Development of novel antioxidants: Design, synthesis, and reactivity. J. Org. Chem. 68, 7023-7032.

5. Wright, J. S., Flueraru, M., Durst, T., and Babiuc, G. (2002) Reaction kinetics of novel antioxidants in HL-60 cell cultures. Free Rad. Biol. Med. 33, Suppl. 2. 


\section{b). Conference Presentations and Posters}

1. Flueraru, M., Chichirau, A., Chepelev, L., Willmore, W.G., Durst, T., Charron, M., and Wright, J.S. "Testing naphthalenediols for toxicity and protective effects against oxidative stress in rat cortical neurons" Free Rad. Biol. Med. 39, Suppl. 1.

2. Wright, J.S., Flueraru, M., Chichirau, A., Willmore,W.G., Durst,T., and Charron, M. (Sept.7-10, 2005) " Cytotoxicity and cytoprotective activity in naphthalenediols depends on their tendency to form naphthoquinones ", presented at The Annual Meeting of the Oxygen Club of California (OCC) on Oxidants and Antioxidants in Biology, Alba, Italy.

3. Charron, M., Hussain, H.H., Durst, T., Wright, J.S., Flueraru, M., Chichirau, A., Chepelev, L. (Nov, 2004) "Novel 2,3-naphthalenediol antioxidants: Design, synthesis and reactivity" presented at $15^{\text {th }}$ Quebec/Ontario Minisymposium in Synthetic and Bioorganic Chemistry, Aylmer, Canada.

4. Wright, J.S., Flueraru, M., Chichirau, A, and Chepelev, L.L. (May, 2004); "Designer antioxidants"; presented at $4^{\text {th }}$ Scientific Meeting of the Oxidative Stress Consortium, Toronto, Canada.

5. Flueraru, M., Chichirau, A., L. Chepelev, L., and Wright, J.S. (April 26-27, 2004) "Synthetic catechols and naphthalenediols: cytotoxicity and cytoprotective effects against oxidative stress", presented at Structure-Based Drug Design, Cambridge Healthetich Institute, Boston, MA,USA.

6. Flueraru, M., Chichirau, A., Wright, J.S., and Willmore, W.G. (Nov., 2003); "Novel synthetic antioxidants as anti-aging compounds", presented at The 6th Annual Chemistry and Biochemistry Graduate Research Conference, Montreal, Canada. 
7. Chichirau, A., Flueraru, M., Wright, J.S., and Willmore,W.G. (Nov., 2003) "Antioxidant or prooxidant? Cell toxicity of novel catechols", presented at The 6th Annual Chemistry and Biochemistry Graduate Research Conference, Montreal, Canada.

8. Wright, J.S.; Flueraru, M.; Chichirau, A.; Chepelev,L.; Willmore,W.G.; Miller, J.D.; Poulter, M.O.; Debutte,M.; Pappas, B.; Durst, T.; Babic, G.; Hussain, H.H.; Barclay, L.R.C.; and Ingold, K.U.; (Aug.,2003); "Novel synthetic antioxidants as age-retarding compounds: Design strategy, synthesis and testing in chemical systems and cell cultures ",presented at The $39^{\text {th }}$ IUPAC Congress and the $86^{\text {th }}$ Conference of the Canadian Society for Chemistry, Ottawa, Canada. 